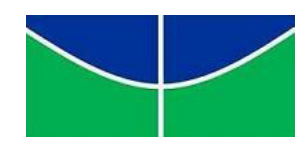

Universidade de Brasília Instituto de Letras

Departamento de Teoria Literária e Literaturas

Programa de Pós-graduação

Doutorado em Literatura Brasileira

\title{
A NARRATIVA DRAMÁTICA DE AUTRAN DOURADO: Hermenêutica, arte e jogo como escrita da morte em O Risco do Bordado
}

ROBSON ANDRÉ DA SILVA 
Universidade de Brasília

ROBSON ANDRÉ DA SILVA

\section{A NARRATIVA DRAMÁTICA DE AUTRAN DOURADO:}

Hermenêutica, arte e jogo como escrita da morte em O Risco do Bordado

Tese de doutorado apresentada ao Programa de Pós-Graduação em Literatura Brasileira da Universidade de Brasília, como parte dos requisitos necessários à obtenção do título de Doutor em Literatura Brasileira.

Orientador: Prof. Dr. Henryk Siewierski.

Brasília-DF

2016 


\section{BANCA EXAMINADORA}

Prof. Dr. Henryk Siewierski

PósLit/TEL/UnB

Presidente

Profa. Dra. Alessandra Matias Querido

Universidade Católica de Brasília

Examinadora

Prof. Dr. João Batista Cardoso

Universidade Federal de Goiás

Examinador

Prof. Dr. André Luís Gomes

PósLit/TEL/UnB

Examinador

Prof. Dr. Robson Coelho Tinoco

PósLit/TEL/UnB

Examinador

Prof. Dr. João Vianney Cavalcanti Nuto

PósLit/TEL/UnB

Suplente 


\section{DEDICATÓRIA}

À minha mãe Maria Teonildes da Silva (in memoriam), por todos os amorosos dias de nossa existência;

Aos meus filhos Marcelo e Diego Rodrigues da Silva, pelo amor que recria o nosso mundo;

Ao meu pai Israel André da Silva, por tudo que vivemos juntos;

Aos meus irmãos João, Edmilson, Israel, Adriana, Vera e Fátima, pela união e alegria cotidianas. 


\section{AGRADECIMENTOS}

Ao Professor Doutor Henryk Siewierski, pela amizade, competência, seriedade e orientação criteriosa;

Às Professoras Doutoras Rita de Cassi Pereira e Maria Isabel Edom, pelas considerações durante a qualificação desta tese;

Aos Professores Doutores Ronaldes de Melo e Souza e Maria Lucia Guimarães de Faria, pelos anos de aprendizagem hermenêutica;

À minha amiga Isabel Cristina Corgosinho, pelo incentivo neste caminho literário da vida;

À minha amiga Lívila Pereira Maciel, pela convivência poético-pensante;

À minha amiga Paula Tatiane Peixoto Mariano, pelos dias e diálogos inesquecíveis;

Aos meus amigos Marco Túlio Ribeiro Pachêco, Maurício Lemos Izolan, Marcelo Américo Martins da Silva e José Nunes de Oliveira Filho, pela eterna força e coragem na travessia;

Aos Professores do Curso de Letras da Universidade Católica de Brasília, Lívila Pereira, Mariza Vieira, Christine Maria, Déborah Christina, Deise Ferrarini, Rosângela de Nazareth, Vera Lúcia Cordeiro, Alessandra Matias, Carolina Coelho, Michelle Andressa, Michelle de Abreu, Andréa Coutinho e Wallace Soares, pela amizade cotidiana e esperança de um mundo renovado;

Aos alunos dos Cursos de graduação em Letras e pós-graduação em Literatura Brasileira da Universidade Católica de Brasília, por todos os dias de ensino, aprendizagem e pesquisa. 


\section{RESUMO}

A narrativa dramática de Autran Dourado tem, inegavelmente, uma importância extraordinária na mudança de paradigma da literatura brasileira moderna e contemporânea. Desde as primeiras obras Teia (1947), Sombra e Exílio (1950), Tempo de Amar (1952), passando por A Barca dos Homens (1961), Ópera dos Mortos (1967), O Risco do Bordado (1970), Os Sinos da Agonia (1974), Um Artista Aprendiz (1989), Vida, Paixão e Morte do Herói (1994) e O Senhor das Horas (2006), o escritor mineiro vem trabalhando com a concepção lúdica da arte, a modulação do perspectivismo narrativo e a mistura dos gêneros literários, propostas pelos princípios poéticos do Barroco, do Romantismo, do Simbolismo e do Modernismo. Tais procedimentos o levaram a instaurar novas possibilidades narrativas que transcendem as meras técnicas clássicas, realistas e psicológicas de apresentação do narrador, do espaço, do tempo, da história e dos personagens, utilizando, sobretudo, o refletor narrativo, o fluxo de consciência, o monólogo interior, a prosa epifânica, a narrativa em blocos, a estrutura aberta do barroco, o sentimento trágico, a ficção mitopoética, o dialogismo e a polifonia como eixos fundamentais de construção romanesca. Assim, pretendemos mostrar, principalmente, que a obra O Risco do Bordado assume uma posição estratégica na construção lúcida e consciente de uma poética do romance autraniano, pois desvela a lei geral ou chave hermenêutica de seu universo crítico e criativo, ou seja, a representação da arte como jogo e escrita da morte. A narrativa dramática de Autran Dourado configura-se, portanto, como a interação lúdica da arte e da vida no horizonte finito da experiência humana.

Palavras-chave: Autran Dourado. Narrativa dramática. Hermenêutica, arte e jogo. Escrita da morte. 


\begin{abstract}
The dramatic narrative of Autran Dourado has, undeniably, an extraordinary importance in the paradigm change of the modern and contemporary Brazilian Literature. Since his first works, from Teia (1947), Sombra e Exílio (1950), Tempo de Amar (1952), all the way to A Barca dos Homens (1961), Ópera dos Mortos (1967), O Risco do Bordado (1970), Os Sinos da Agonia (1974), Um Artista Aprendiz (1989), Vida, Paixão e Morte do Herói (1994) and O Senhor das Horas (2006), the writer, from the Brazilian state of Minas Gerais, has been working with a ludic art conception, the modulation of the narrative perspectivism and the mixture of literary genres, proposed by the poetic principles of the Baroque, the Romanticism, the Symbolism and the Modernism. Such procedures led him to inaugurate new narrative possibilities which transcend the mere classical, realistic, and psychological presentation techniques of the narrator, the space, the time, the plot and the characters, using, withal, the narrative reflector, the stream-ofconsciousness, the interior monologue, the epiphanic prose, the blocks of narrative, the open structure of the Baroque, the tragic sentiment, the mythopoetical fiction, the dialogism and the polyphony as fundamental axes of the romanesque construction. Thus, we intend to show, principally, that the work $O$ Risco do Bordado assume a strategic position in a lucid and conscious poetic construction of the autranian novel, for it reveals the general law or hermeneutical key of his critical and creative universe, that is, the representation of art as play and the writing of death. The dramatic narrative of Autran Dourado, therefore, sets itself as the ludic interaction of art and life in the finite horizon of human experience.
\end{abstract}

Keywords: Autran Dourado. Dramatic Narrative. Hermeneutics, art and play. The writing of death. 
"A arte como construção e jogo. [...] Jogo e construção, o aspecto lúdico da montagem, a múltipla leitura que o barroco propõe, tudo isso cada vez me fascina mais e mais."

Autran Dourado. Uma Poética de Romance: Matéria de Carpintaria.

"Condenado à solidão, observador lúcido, atento e racional da vida, o artista é um ser que caminha mais rápida e claramente do que os outros mortais para a morte."

Autran Dourado. Uma Poética de Romance: Matéria de Carpintaria.

"Mergulhava no ventre do tempo, nas suas águas lodosas, à procura de algum sinal. Tentava sair do tempo, da densa nebulosa que tudo abarcava e dissolvia, e buscava algum sinal, um acontecimento qualquer de calendário ou folhinha, que lhe desse a certeza de sua idade naquela época, quando aquilo primeiro aconteceu."

Autran Dourado. O Risco do Bordado, VI, "O Salto do Touro". 


\section{SUMÁRIO}

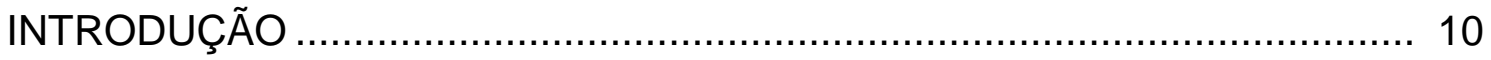

I. HERMENÊUTICA, ARTE E JOGO COMO ESCRITA DA MORTE ............. 15

1. SER, VERDADE E ARTE EM MARTIN HEIDEGGER .......................... 17

1.1. A compreensão ontológica da verdade ............................................ 17

1.2. A poesia originária da arte ............................................................ 45

2. ARTE, JOGO E LINGUAGEM EM HANS-GEORG GADAMER ............... 54

2.1. A arte como jogo da verdade ......................................................... 54

2.2. A compreensão lúdica da linguagem ............................................... 62

3. A ARTE DRAMÁTICA, A VISÃO DIONISÍACA E A ESCRITA DA MORTE . 67

3.1. A tragédia grega e o drama de paixão .............................................. 67

3.2. A visão dionisíaca do mundo e a escrita da morte ............................. 70

II. A NARRATIVA DRAMÁTICA DE AUTRAN DOURADO …........................ 80

4. O PERSPECTIVISMO NARRATIVO E A ARTE DRAMÁTICA .................. 80

4.1. O perspectivismo e a arte do romance …………........................... 80

4.2. A narrativa personativa e a técnica do refletor ................................. 81

5. O DRAMA DE PAIXÃO EM O RISCO DO BORDADO …......................... 86

5.1. A estrutura lúdica de composição ou Planta baixa ............................. 89

5.2. Os blocos narrativos ou Poema de sete faces .................................. 93

5.2.1. Viagem à Casa da Ponte ou A origem mítica do mundo ......... 100

5.2.2. Nas Vascas da Morte ou $O$ poeta é um fingidor ..................... 113

5.2.3. Valente Valentina ou Em busca do tempo perdido ................. 138

5.2.4. As Voltas do Filho Pródigo ou O som e a fúria ....................... 153

5.2.5. Assunto de Família ou $O$ rio do nada ................................... 162

5.2.6. O Salto do Touro ou O labirinto do tempo .............................. 172

5.2.7. As Roupas do Homem ou O eterno retorno do ser ................. 192

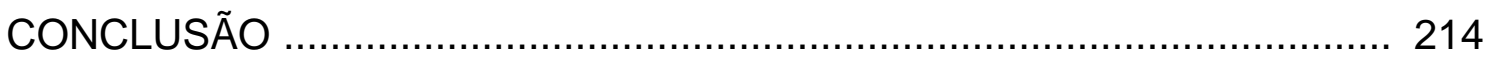

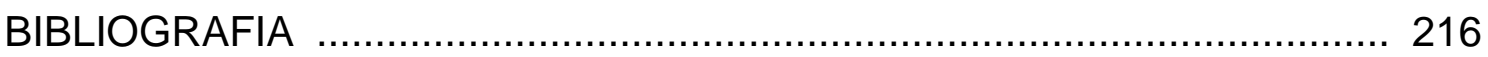




\section{INTRODUÇÃO}

A obra de Autran Dourado tem, inegavelmente, uma importância extraordinária na mudança de paradigma da literatura brasileira moderna e contemporânea. Desde as primeiras obras Teia (1947), Sombra e Exílio (1950), Tempo de Amar (1952), passando por A Barca dos Homens (1961), Ópera dos Mortos (1967), O Risco do Bordado (1970), Os Sinos da Agonia (1974), Um Artista Aprendiz (1989), Vida, Paixão e Morte do Herói (1994) e O Senhor das Horas (2006), o escritor mineiro vem incorporando o diálogo das artes e dos gêneros literários proposto pelos princípios poéticos do Barroco, do Romantismo, do Simbolismo e do Modernismo. Tal procedimento o levou a instaurar novas possibilidades narrativas que transcendem as meras técnicas clássicas, realistas e psicológicas de apresentação do narrador, do espaço, do tempo, da história e dos personagens, utilizando, sobretudo, o refletor narrativo, o fluxo de consciência, o monólogo interior, a prosa epifânica, a narrativa em blocos, a estrutura aberta do barroco, o sentimento trágico, a ficção mitopoética, o dialogismo e a polifonia como eixos fundamentais de construção romanesca. Assim, pretendemos mostrar, principalmente, que a narrativa dramática O Risco do Bordado (1970) assume uma posição estratégica na construção lúcida e consciente de uma poética do romance autraniano, pois desvela a lei geral ou chave hermenêutica das obras anteriores e posteriores, ou seja, a representação da arte como jogo e escrita da morte.

Autran Dourado se insere na grande tradição moderna que, lúdica e lucidamente, questiona a tradição clássica e promove a interpenetração das artes e das várias áreas do conhecimento. Pretendemos mostrar, assim, que o escritor mineiro mantém um diálogo concriativo com a narrativa barroca e multifacetada de Miguel de Cervantes; com a filosofia poética da composição de Edgar Allan Poe; com a lírica moderna dos simbolistas franceses Baudelaire, Rimbaud e Mallarmé, que promoviam a correspondência concreta do mundo e do homem, da alma e do corpo, da razão e da sensibilidade, da identidade e da alteridade; e, sobretudo, com a dramaticidade e temporalidade 
do romance de Gustave Flaubert, Henry James, James Joyce, Marcel Proust, entre outros.

Condizente com a desconstrução filosófica ou visão moderna e poética do mundo, o autor relaciona as imagens múltiplas do jogo narrativo à experiência finita e relativa do conhecimento. Nesse sentido, importa ressaltar que a visão ou situação narrativa predominantemente personativa de muitos romances de Autran Dourado, especialmente O Risco do Bordado, já de si coloca o leitor diante de um mundo em que a verdade subjetiva e a objetiva interagem, pois representa a integração das vozes narrativas de primeira e terceira pessoas. Essa narrativa personativa, que tem seus antecedentes em Gustave Flaubert, Henry James e James Joyce, foi absorvida exemplarmente por Autran Dourado, permitindo-Ihe romper com o estatuto tradicional do narrador onisciente e apresentar cenicamente as imagens refletidas na consciência de um ou vários personagens. Herdeira da tradição barroca, simbolista e modernista, a situação narrativa personativa se manifesta como encenação trágica da visão e da verdade múltiplas não só dos personagens, mas, sobretudo, da própria obra de Autran Dourado. Assim como em Dom Quixote, interagem e multiplicam-se ludicamente o espaço e o tempo, o interior e o exterior, a ficção e a realidade, o autor e o leitor, o artista e a obra. $\mathrm{Na}$ arte moderna, o processo de formação da obra e a experiência de transformação do artista mutuamente se implicam. Assim, desde Três Histórias na Praia (1955), centrando e descentrando os acontecimentos na vida e na arte do personagem-metáfora João da Fonseca Nogueira, habitante da cidade imaginária-real Duas Pontes, a obra de Autran Dourado amplia o horizonte do conhecimento humano e alcança dimensões míticas e universais. O retrato do artista João da Fonseca Nogueira é pintado simultaneamente dentro e fora de sua própria consciência, por si mesmo e pelo narrador personativo, pois o leitor vê o personagem também interna e externamente. Assim como a construção da própria obra, a experiência ou formação (Bildung) do artista João é mostrada no texto pela integração dos aspectos espaciais e temporais, inteligíveis e sensíveis. Portanto, a obra autraniana exige não apenas a leitura superficial, mas, sobretudo, a leitura hermenêutica, interdisciplinar e profunda do texto e do mundo. 
Este trabalho tem, assim, por objetivo fundamental mostrar que a arte como jogo e escrita da morte no romance de Autran Dourado desvela-se, sobretudo em O Risco do Bordado (1970), como a interação mútua da ficção narrativa e do drama trágico, configurando assim o mundo concreto da experiência humana. Divide-se, portanto, em duas partes, totalizando cinco capítulos que se iluminam reciprocamente.

A primeira parte intitula-se Hermenêutica, arte e jogo como escrita da morte e divide-se em três capítulos. O capítulo 1 denomina-se "Ser, verdade e arte em Martin Heidegger" e pretende mostrar como o eminente pensador, na esteira da desconstrução nietzschiana da metafísica, relaciona a questão hermenêutica da verdade à representação da morte como experiência trágica do conhecimento. O capítulo 2, "Arte, jogo e linguagem em Hans-Georg Gadamer", elucida o conceito de jogo como instância privilegiada de compreensão da obra de arte. Dessa maneira, confirmaremos que a arte não é a conformação, mas o acontecimento lúdico da verdade ou escrita da finitude na narrativa de Autran Dourado. Desdobrando esta perspectiva, torna-se, portanto, imprescindível, no capítulo 3 , intitulado "A arte dramática, a visão dionisíaca e a escrita da morte", mostrar também a importância do drama trágico grego e sua relação com o mito e o culto de Dioniso, para que se compreenda a sua incorporação pela ficção narrativa moderna e contemporânea. O diálogo da narrativa de Autran Dourado com o drama trágico, a visão mitopoética ou dionisíaca do mundo, e sua correspondente poética não-aristotélica, será elucidado segundo pensadores como Nietzsche, Walter F. Otto, Mario Untersteiner, entre outros, bem como a partir das reflexões do próprio escritor mineiro, presentes, implicitamente, nos romances e contos, e, explicitamente, sobretudo, em entrevistas e nos ensaios-fantasia Uma Poética de Romance: Matéria de Carpintaria (1976) e O Meu Mestre Imaginário (1982), cuja singularidade se revela como autoconsciência crítica e teórica do fazer artístico enquanto diálogo concriativo do passado e do presente. 
A segunda parte intitula-se $A$ narrativa dramática de Autran Dourado e se divide em dois capítulos. No capítulo 4, "O perspectivismo narrativo e a arte dramática", trataremos da importância do ponto de vista narrativo para a compreensão do romance moderno e contemporâneo, mostrando, principalmente, a modulação do discurso bivocal de Gustave Flaubert, a contribuição de Henry James ao meditar sobre a arte do romance e ao criar a técnica do refletor narrativo ou a situação narrativa predominantemente personativa; bem como a revolução ou radicalização desta por James Joyce com sua teoria da prosa epifânica e do efeito trágico. A explicitação da narrativa predominantemente personativa será demonstrada, sobretudo, a partir da tipologia hermenêutica do crítico Franz Karl Stanzel, presente em seu livro Narrative Situations in the Novel. Portanto, a compreensão da arte do romance de Autran Dourado implica a elucidação desta técnica dramática de composição. A integração da visão, do espaço e do tempo narrativos no romance moderno e contemporâneo será apresentada a partir dos argumentos não só de teóricos como Percy Lubbock, Wayne C. Booth, Franz K. Stanzel, Gaston Bachelard, Georges Poulet, Hans Robert Jauss, Hans Meyerhoff, entre outros, mas, sobretudo, a partir das reflexões dos próprios romancistas como Gustave Flaubert, Henry James, James Joyce, Marcel Proust e, principalmente, Autran Dourado. Confirma-se, assim, que a interação da teoria e da prática do romance contribui para a configuração discursiva, espacial e temporal da narrativa autraniana. No capítulo 5 , "O drama de paixão em $O$ Risco do Bordado", falaremos da estrutura lúdica de composição ou planta baixa de $O$ Risco do Bordado, de Autran Dourado, e faremos um estudo hermenêutico dos seus sete blocos narrativos regidos singularmente pela escrita da morte. Nas narrativas de Autran Dourado, a morte se apresenta, primordialmente, como a personagem central que interrelaciona os planos da enunciação e do enunciado de seus textos, ou seja, a sua visão lúdica, dionisíaca ou mitopoética do mundo. A questão da finitude e da temporalidade é o problema hermenêutico fundamental que envolve o drama do narrador e dos personagens do universo autraniano.

Por fim, confirmaremos que a arte como jogo e escrita da morte, na narrativa dramática de Autran Dourado, se representa como o símbolo do 
mundo, ou seja, o jogo dramático da ficção e da realidade, da literatura e da existência, da vida e da morte. O personagem-metáfora ou refletor na obra autraniana constroi a existência possível no horizonte finito do tempo. Assim, a memória do passado e a memória do futuro intimamente se relacionam no presente dramático do refletor narrativo. A configuração da existência implica a escrita da finitude humana. Neste sentido, a narrativa dramática de Autran Dourado se insere na grande tradição literária das viagens e das catábases que, integrando poeticamente as faculdades cognitiva, afetiva e volitiva, nos conduzem, da antiguidade à modernidade, ao interior do mundo e da alma, do espaço e do tempo e que se apresentam, sobretudo, nas obras de Homero, Ésquilo, Sófocles, Eurípides, Luciano, Virgílio, Dante, Rabelais, Cervantes, Flaubert, Dostoiévski, Machado de Assis, Euclides da Cunha, Marcel Proust, entre outros. Esperamos comprovar, portanto, que a narrativa de Autran Dourado vem se estruturando e modulando a partir da correspondência das artes barroca, romântica, simbolista e modernista, do hibridismo da lírica, da narrativa e do drama modernos, contribuindo, assim, para a renovação técnica e estilística da literatura brasileira contemporânea. 


\section{HERMENÊUTICA, ARTE E JOGO COMO ESCRITA DA MORTE}

A obra de arte se manifesta originariamente como jogo ou acontecimento da verdade (alétheia). A palavra grega tem, assim, o duplo sentido de velamento (lethe) e desvelamento, indicando sua manifestação nos pensadores originários (Anaximandro, Parmênides e Heráclito) e nos poetas trágicos (Ésquilo, Sófocles e Eurípides), que a correlacionavam com o emergir incessante e poético da natureza (physis), com a representação dramática ou escrita da finitude. No decurso da história da metafísica, a verdade poética se transmuta na verdade filosófica e racional, recebendo de Platão (República) e Aristóteles (Poética) sua condenação ou absolvição em relação a uma causalidade prévia. Foi assim até o advento dos Tempos Modernos, quando Descartes (Discurso do Método) volta a condenar o conhecimento sensível da poesia em benefício de uma visão predominantemente racional do mundo e do ego pensante. Como sabemos, no século XIX, a partir do questionamento de Friedrich Nietzsche, a desconstrução da metafísica implicou uma revisão e consagração do papel do conhecimento poético do mundo, livrando-o do preconceito e moralismo platônico-cristão. Em obras como Genealogia da Moral, A Filosofia na Era Trágica dos Gregos, O Nascimento da Tragédia e Assim Falava Zaratustra, Nietzsche questiona a separação metafísica e recupera a união originária da alma e do corpo, da razão e da paixão, do apolíneo e do dionisíaco presente nos pensadores originários e nos poetas trágicos gregos. A crise geral das ciências europeias, conforme anuncia, em 1936, a fenomenologia de Edmund Husserl (2012), implicou o retorno ao "mundo da vida" (Lebenswelt) concretamente enraizada no tempo. O mundo do ser absoluto não se compatibiliza mais com o mundo deveniente da vida. A verdade poética tantas vezes condenada na história se apresenta, então, mais do que antes, como o caminho urgente para se repensar o mundo e o homem desintegrados pelo totalitarismo da razão.

Nesse caminho divergente da filosofia e da poesia, até o século XIX, houve muitos escritores que, ao contrário dos ditames metafísicos, promoveram o intercâmbio da ciência e da arte, do inteligível e do sensível, da 
vida e da morte, da história e da poesia. Podemos citar, entre outros, Homero, Luciano, Ésquilo, Virgílio, Dante, Rabelais, Cervantes, Goethe, Dostoiévski e Machado de Assis, que, alheios à causalidade e ao determinismo, mostraram o dialogismo, o plurilinguismo e o relativismo do ser e da verdade do mundo. Nas viagens ou catábases ao interior do mundo e da alma, esses escritores ampliaram a experiência da verdade, da vida e da morte, propondo a religação dos saberes e o intercâmbio dos discursos. A escrita da finitude nesses escritores nunca representou a clausura, mas a abertura do sentido e do mundo. Promovendo o diálogo dos mortos e dos vivos, o mundo e o homem se renovavam incessantemente.

Seguindo, então, o caminho das descobertas da verdade artística, Nietzsche nos possibilitou um novo diálogo da filosofia e da arte, que veio a ser continuado, no século XX, entre outros, por pensadores como Martin Heidegger e Hans-Georg Gadamer. Consideramos importantes as suas reflexões hermenêuticas acerca do jogo da arte e da verdade para a compreensão de uma escrita da finitude na obra O Risco do Bordado, de Autran Dourado. 


\section{SER, VERDADE E ARTE EM MARTIN HEIDEGGER}

"Die Kunst ist als das Ins-Werk-Setzen der Wahrheit Dichtung."

("A arte é, como o pôr-em-obra da verdade, poiesis.")

Martin Heidegger

1. 1. A compreensão ontológica da verdade

O problema da compreensão na hermenêutica fenomenológica de Martin Heidegger implica, sobretudo, a questão do sentido ou verdade originária do ser (die Frage nach dem Sinn von Sein), conforme se anuncia em sua obra magna Ser e Tempo (Sein und Zeit), publicada em 1927 (HEIDEGGER, 1988b, Introdução: Exposição da questão sobre o sentido do ser, § 1 a 8, p. 25-71). Todos os passos do pensamento heideggeriano, inclusive a virada (Kehre), apresentam-se como provocações ou elucidações hermenêuticas dessa questão primordial. Assim, somente através da estrutura prévia da compreensão, acontece o desvelamento da verdade no horizonte vital do intérprete. Como veremos adiante, não se trata simplesmente de um domínio do ente, mas da manifestação do próprio ser.

Retomando e ampliando a contribuição dada por Schleiermacher e Dilthey, bem como pela fenomenologia de Husserl, com respeito ao problema da compreensão, Martin Heidegger afirma: "Enquanto projeto, a compreensão é o modo de ser da pre-sença" (HEIDEGGER, 1988b, § 31. A pre-sença como compreensão, p. 201). Não é uma atitude subjetiva que ele toma quando quer, mas a condição sine qua non para a realização de sua existência. O homem, diz Heidegger, é o ente por excelência, pois possui em seu ser a possibilidade de questionar. E, ao questionar, o homem sai do âmbito restrito da subjetividade e experimenta o advento do próprio ser. Heidegger usa a palavra Dasein (pre-sença) (HEIDEGGER, 1988b, § 2. A estrutura formal da questão do ser, p. 33) para pensar o modo próprio de ser do homem, a saber, o estar aberto $(D a)$ ao apelo do ser (Sein). A palavra Dasein mostra a essência originária do homem, ou seja, a abertura ao questionamento do Ser. Deste 
modo, Heidegger visa superar a essência metafísica do homem como animal racional, ou seja, a perspectiva do homem como sujeito dominante da verdade. Prepara-se, então, o salto da visão subjetiva à visão projetiva do próprio Ser. Nesse sentido, o homem não é, devém constantemente sem nunca se enclausurar em uma modalidade de ser definitiva. Provocado e convocado pela verdade ou sentido do ser, o Dasein existe (ex-siste), ou seja, abre-se à possibilidade, e não somente à identidade do próprio ser. Portanto, a compreensão revela que a experiência humana é a da finitude ou alteridade radical do ser.

A revolução heideggeriana consiste em mostrar que a compreensão não se dá, primordialmente, na relação lógica (ôntica) entre o sujeito e o objeto, mas em uma dimensão ontológica em que ambos interagem continuamente. Anterior à proposição de um sujeito com referência a um objeto, dá-se a estrutura circular da compreensão. O círculo hermenêutico da compreensão, de origem diltheyniana, recebe uma amplitude ontológica no pensamento heideggeriano. Assim, a interação da parte interpretada com o seu todo conjuntural só é possível graças à estrutura pressupositiva da compreensão (Vorstruktur des Verstehens). A parte antecipa ou projeta o todo, e vice-versa. Só se interpreta a parte com relação à totalidade do sentido. Importa salientar que a circularidade da compreensão não é lógica, pois o todo nunca é a soma, porém a possibilidade das partes. Apenas em uma totalidade conjuntural (HEIDEGGER, 1988b, § 18. Conjuntura e significância: a mundanidade do mundo, p. 127-134) de sentido previamente dada, "algo" pode se manifestar como "algo". Afirma Heidegger:

\footnotetext{
O que se abre na compreensão, o compreendido, é sempre de tal modo acessível que pode explicitar-se em si mesmo "como isto ou aquilo". O "como" constitui a estrutura da explicitação do compreendido; ele constitui a interpretação. (HEIDEGGER, 1988b, § 32. Compreensão e interpretação, p. 205).
}

Na compreensão, o Dasein "vê" algo como mesa, porta, carro, ponte, prossegue Heidegger, e não precisa expor o que foi interpretado na circunvisão numa proposição determinante (idem). Antes de tudo, há a articulação do que foi compreendido na forma da interpretação, e não simplesmente a proposição 
temática do ente. $\mathrm{O}$ "como" não é senão a constituição existencial a priori da compreensão (apriorische existenziale Verfassung des Verstehens) (HEIDEGGER, 1988b, § 32. Compreensão e interpretação, p. 206).

Toda interpretação só é possível graças ao caráter prévio da compreensão. Sendo assim, a interpretação não é senão "elaborar as possibilidades projetadas na compreensão" (die Ausarbeitung der im Verstehen entworfenen Möglichkeiten) (HEIDEGGER, 1988b, § 32. Compreensão e interpretação, p. 204). Inseparáveis, a compreensão e a interpretação constituem a possibilidade de experiência não-metafísica da verdade ou sentido do ser, reduzindo a um plano secundário a ciência ou proposição do ente demasiado subjetivo.

A interpretação de algo como algo funda-se, essencialmente, na estrutura pressupositiva da compreensão (Vor-Struktur des Verstehens), ou seja, na articulação de uma posição prévia (Vorhabe), visão prévia (Vorsicht) e concepção prévia (Vorgriff) com respeito ao fenômeno manifesto (HEIDEGGER, 1988b, § 32. Compreensão e interpretação, p. 206-207). O conjunto dessas pressuposições denomina-se situação hermenêutica. Dessa maneira, diz Heidegger, a questão sobre o sentido do ser é uma indagação sobre o próprio ser enquanto se dá dentro da compreensibilidade do Dasein, e não ao ente ou ao ser enquanto fundamento do ente. A questão é do ser, e não do ente. É rumo a uma ontologia da compreensão que se encaminha $o$ pensamento heideggeriano. A pergunta hermenêutica é acerca do sentido ou verdade do ser, e não do significado do ente. Noutras palavras, "Sentido é a perspectiva em função da qual se estrutura o projeto pela posição prévia, visão prévia e concepção prévia. É a partir dela que algo se torna compreensível como algo." (HEIDEGGER, 1988b, § 32. Compreensão e interpretação, p. 208, itálicos do autor).

Quem verdadeiramente compreende já de si é compreendido ou questionado pelo próprio jogo circular da compreensão. Não há, de um lado, o mundo e, de outro, a existência humana, pois ambos estão sempre em interação contínua. O Da-sein é, em sua essência originária, ser-no-mundo (In- 
der-Welt-sein) (HEIDEGGER, 1988b, § 12. Caracterização prévia do ser-nomundo a partir do ser-em como tal, p. 90-98). Antes de emitir qualquer conceito sobre si e os entes intramundanos, o homem já existe numa conjuntura ou totalidade concreta de sentido, ou seja, num mundo previamente re-velado (HEIDEGGER, 1988b, § 39. A questão da totalidade originária do todo estrutural da pre-sença, p. 243-247), que se mostra como horizonte da compreensão. Anterior a tudo o que é, o homem experimenta a irrupção, o evento ou a abertura (Welt) do ser. Noutros termos, o homem (Dasein) encontra-se e desencontra-se com tudo o que é (ente) porque já mora no (inder) mundo (Welt) da prévia compreensão do Ser (Sein).

A situação hermenêutica ou o horizonte histórico do intérprete é posto em jogo pelo movimento prévio da compreensão ontológica, e não pela subjetividade do sujeito. $O$ homem pertence à abertura do ser, e não o contrário. O Ser como horizonte histórico da compreensão é quem, primordialmente, funda a interação dialógica do mundo e da existência: "Em toda compreensão de mundo, a existência também está compreendida e viceversa" (Im jedem Verstehen von Welt ist Existenz mitverstanden und umgekehrt) (HEIDEGGER, 1988b, § 32. Compreensão e interpretação, p. 209). Antes se dá uma interação, e só depois ocorre a separação lógica entre sujeito e objeto, ou seja, a proposição do ente acerca do que é ou não é.

Heidegger elucida ontologicamente o círculo hermenêutico da compreensão insistindo no ponto de que ele não se realiza como um circulus vitiosus. Não se trata de um círculo lógico-dedutivo, mas de um círculo que "exprime a estrutura-prévia existencial, própria da pre-sença" (der Ausdruck der existenzialen Vor-Struktur des Daseins selbst) (HEIDEGGER, 1988b, § 32. Compreensão e interpretação, p. 210, itálicos do autor). A compreensão (Verstehen) é o poder-ser da própria pre-sença (das Seinkönnen des Daseins selbst) (Idem). Não se esgotando na identidade (ser como presença constante = ente), o Dasein comparece como possibilidade ou alteridade do ser. Noutras palavras, o Dasein não se define nem como sujeito nem como objeto, dado que, originariamente, existe como projeto (Entwurf) da compreensão do próprio ser. Visando superar dialeticamente a visão antropocêntrica (subjetiva) do 
mundo e da existência, o pensamento heideggeriano põe-se a caminho da questão ontocêntrica da verdade. O homem não é o senhor, mas tão-somente o jogador ou participante do projeto lúdico da compreensão do ser. Ele não define, pois sempre é definido ou jogado pelo próprio acontecimento histórico do ser. Assim, no círculo da compreensão, o ponto de vista do intérprete sempre está envolvido de tal maneira que nele se esconde "a possibilidade positiva do conhecimento mais originário" (eine positive Möglichkeit ursprünglichsten Erkennens) (Idem).

A ciência epistemológica é superada pela experiência hermenêutica que interroga não pela explicação, mas pela compreensão ontológica do mundo da existência e, ao mesmo tempo, pela existência do mundo. Heidegger mostra que as pressuposições ontológicas do conhecimento histórico ultrapassam, em princípio, a ideia de rigor das ciências mais exatas e, por fim, conclui dizendo:

O "círculo" da compreensão pertence à estrutura do sentido, cujo
fenômeno tem suas raízes na constituição existencial da pre-sença,
enquanto compreensão que interpreta. O ente em que está em jogo
seu próprio ser como ser-no-mundo possui uma estrutura de círculo
ontológico. (HEIDEGGER, 1988b, $\$ 32$. Compreensão e
interpretação, p. 210).

A estrutura pressupositiva da compreensão, que se articula em toda interpretação, revela a finitude radical da experiência humana. A existência nunca se reduz à identidade constante ou a um solo seguro, mas, originariamente, efetiva-se como abissal alteridade ou possibilidade do ser. Noutras palavras, a morte é inerente à constituição existencial do próprio homem enquanto Da-sein, e, por isso, é quem possibilita o advento de novas experiências ou possibilidades do ser. Portanto, a natureza prévia da compreensão é o evento ou fenômeno originário da Verdade do Ser na estrutura temporal da existência. Trataremos, pois, de elucidá-lo a seguir.

Em Ser e Tempo, Heidegger afirma que a correlação ou interação originária (ursprünglichen Zusammenhang) da verdade (Wahrheit) com o Ser (Sein) remete-nos ao âmbito da problemática ontológica fundamental (fundamentalontologischen Problematik) (HEIDEGGER, 1988b, § 44. Pre- 
sença, abertura e verdade, p. 280-300). Partindo do conceito tradicional da verdade, cujo caráter não é senão derivado, elucida-nos o fenômeno originário da verdade (Das ursprüngliche Phänomen der Wahrheit). Deste modo, a verdade não é apenas a concordância entre a proposição (o juízo) e seu objeto, mas, sobretudo, o evento que "se dá" (es Wahrheit gibt) como inesgotável processo de compreensão do ser.

O conceito tradicional da verdade, desenvolvido a partir de Aristóteles, caracteriza-se como a concordância ou adequação lógica entre o juízo e seu objeto (adaequatio intellectus et rei). No entanto, questiona Heidegger, como é possível a relação de concordância entre intellectus e res ou, noutros termos, entre sujeito e objeto? Qual o contexto ontológico que sustenta essa relação? Se conhecer é julgar algo como verdadeiro (als wahres), a que remete o emissor de qualquer proposição como, por exemplo, "o quadro na parede está torto", quando ele julga? Certamente ao quadro real na parede (HEIDEGGER, 1988b, § 44. Pre-sença, abertura e verdade, p. 285). A relação de concordância entre sujeito julgante e objeto julgado só é possível porque o próprio ente visado (o quadro) mostra-se assim como ele é em si mesmo. Assim, não se verifica antes uma concordância entre sujeito e objeto, mas, sobretudo, "o ser e estar descoberto do próprio ente" (das Entdeckt-sein des Seienden) (HEIDEGGER, 1988b, § 44. Pre-sença, abertura e verdade, p. 286). A verdade originária não consiste no juízo ou proposição, mas no desvelamento constante do ente em seu ser. Nas palavras de Heidegger:

A proposição é verdadeira significa: ela descobre o ente em si mesmo. Ela propõe, indica, "deixa ver" ( $\alpha \pi \delta ́ \varphi \alpha v \sigma \varsigma)$ o ente em seu ser e estar descoberto. O ser-verdadeiro (verdade) da proposição deve ser entendido no sentido de ser-descobridor. (HEIDEGGER, 1988b, § 44. Pre-sença, abertura e verdade, p. 286, itálicos do autor).

A proposição verdadeira implica que o ente previamente se mostre em seu ser, que se abra à compreensão. A primordial abertura ou manifestação do ser, segundo Heidegger, refere-se à palavra grega $\alpha \lambda \eta \theta \varepsilon ı \alpha$ (Alétheia), ou seja, des-velamento. A Alétheia como fenômeno originário da verdade já transparece no pensamento poético de Heráclito (séc. $V$ a. C.), afirma o eminente autor em sua obra Heráclito (A Origem do Pensamento Ocidental. Lógica. A Doutrina do 
Lógos) (HEIDEGGER, 1988a). E o mesmo Heráclito, em seu fragmento 1, enuncia:

Com o Logos, porém, que é sempre, os homens se comportam como quem não compreende tanto antes como depois de já ter ouvido. Com efeito, tudo vem a ser conforme e de acordo com este Logos e, não obstante, eles parecem sem experiência nas experiências com palavras e obras, iguais às que levo a cabo, discernindo e dilucidando, segundo o vigor, o modo em que se conduz cada coisa. Aos outros homens, porém, Ihes fica encoberto tanto o que fazem acordados, como se lhes volta a encobrir o que fazem durante 0 sono. (ANAXIMANDRO, PARMÊNIDES, HERÁCLITO, 1991, p. 59).

E Heidegger, por sua vez, complementa:

O ser-verdadeiro do $\lambda o ́ \gamma o \varsigma$ enquanto $\alpha \pi \delta ́ \varphi \alpha v \sigma \varsigma$ é $\alpha \lambda \eta \theta \varepsilon v a v$, no modo de $\alpha \pi o \varphi \alpha i ́ v \varepsilon \sigma \theta \alpha u v$ : deixar e fazer ver (descoberta) o ente em seu desvelamento, retirando-o do velamento. A $\alpha \lambda \eta \theta \varepsilon \imath \alpha$ [...] indica as "coisas elas mesmas", o que se mostra, o ente na modalidade de sua descoberta. (HEIDEGGER, 1988b, § 44. Presença, abertura e verdade, p. 287, itálicos do autor).

Ser-verdadeiro enquanto ser-descobridor é um modo de ser do Dasein. Já o descobrir é um modo de ser-no-mundo. Noutras palavras, na circunvisão o Dasein descobre entes intramundanos e, por sua vez, a descoberta desses se funda na abertura do mundo. O Dasein, enquanto abertura constituída de disposição, compreensão e discurso, possibilita o fenômeno mais originário da verdade. Ele abre e descobre o que se abre. Pode-se afirmar, então, que "a pre-sença é ou está 'na verdade" (Dasein ist "in der Wahrheit") (HEIDEGGER, 1988b, § 44. Pre-sença, abertura e verdade, p. 289, itálicos do autor). Para fundamentar a afirmativa, Heidegger enumera quatro pontos pertencentes à constituição ontológica do Dasein, a saber: 1. A abertura em geral como possibilidade de descoberta dos entes intramundanos; 2 . O estar-lançado como ser num mundo determinado. A abertura é, em sua essência, fatual; 3. $O$ projeto como constituição do ser que se abre para o seu poder-ser como compreensão. O Dasein pode-se compreender tanto a partir do "mundo" e dos outros entes, quanto a partir do seu poder-ser mais próprio. O Dasein abre-se para si mesmo em seu poder-ser mais próprio e como tal; 4. A de-cadência como possibilidade de o Dasein se perder sempre no impessoal, no falatório, na curiosidade e na ambigüidade. Nesse sentido, o Dasein também "é e está 
na não verdade" (Dasein ist in der Unwahrheit) (HEIDEGGER, 1988b, § 44. Pre-sença, abertura e verdade, p. 290, itálicos do autor). O Dasein não somente se abre como também se fecha à possibilidade de ser. Assim, o descobrimento dos entes intramundanos já de si é o seu encobrimento.

A interpretação ontológico-existencial do fenômeno da verdade trouxe como resultados: "1. Verdade no sentido mais originário é a abertura da presença à qual pertence a descoberta dos entes intramundanos; 2. A pre-sença é e está, de modo igualmente originário, na verdade e na não verdade" (HEIDEGGER, 1988b, § 44. Pre-sença, abertura e verdade, p. 291-292). Com base nessas considerações, afirma Heidegger:

\begin{abstract}
A proposição não é o "lugar" primário da verdade. Ao contrário, a proposição, enquanto modo de apropriação da descoberta e enquanto modo de ser-no-mundo, funda-se no descobrimento ou na abertura da pre-sença. A "verdade" mais originária é o "lugar" da proposição e a condição ontológica de possibilidade para que a proposição possa ser verdadeira ou falsa (possa ser descobridora ou encobridora). (HEIDEGGER, 1988b, § 44. Pre-sença, abertura e verdade, p. 295, itálicos do autor).
\end{abstract}

A verdade da existência, em seu sentido originário, pertence à constituição fundamental do Dasein. Nesse âmbito, ela não é uma propriedade do sujeito, mas um constante dar-se ou doar-se do próprio Ser. Afirma Martin Heidegger: "Só 'se dá' verdade na medida e enquanto a pre-sença é. Só então o ente é descoberto e ele só se abre enquanto a pre-sença é." (HEIDEGGER, 1988b, § 44. Pre-sença, abertura e verdade, p. 295-296, itálicos do autor).

O modo de ser da verdade consiste no seu caráter pressupositivo, ou seja, no seu contínuo dar-se. "Por que devemos pressupor que a verdade se dá?', indaga Heidegger e, a seguir, responde:

"Nós" pressupomos verdade porque "nós", sendo no modo de ser da pre-sença, somos e estamos "na verdade". Nós não a pressupomos como algo "fora" ou "sobre" nós, frente à qual nos comportamos junto com outros "valores". Não somos nós que pressupomos a "verdade", mas é ela que torna ontologicamente possível que nós sejamos de modo a "pressupor" alguma coisa. A verdade possibilita pressuposições. (HEIDEGGER, 1988b, § 44. Pre-sença, abertura e verdade, p. 297, itálicos do autor). 
A estrutura pressupositiva da compreensão mostra-se como sendo fundamentalmente a própria verdade originária do Dasein a dar-se ou acontecer no horizonte finito do tempo. Portanto, sendo o Dasein um ente que, em seu ser, está em jogo o poder ser mais próprio, devemos notar que a verdade previamente já se deu como compreensão e questionamento do nosso próprio ser. A verdade como proposição do ente com respeito a um objeto visado, isto é, o conhecimento como julgamento já de si é a pressuposição da verdade. A proposição é um descobrimento que não esgota o ser da prévia verdade originária. A emissão ou não de um juízo já se articula no horizonte da prévia compreensão da verdade originária do ser, que se vela enquanto se desvela no ente. Não basta, entretanto, deter-se no desvelado (ente), pois também pertence à verdade o simultâneo velamento ou esquecimento do ser. É na meditação sobre o processo simultâneo de desvelamento (Unverborgenheit) do ente e velamento (Verborgenheit) do ser, simbolizado pela palavra grega a-létheia, que se encaminha o pensamento heideggeriano ao elucidar a estrutura pressupositiva da compreensão e o seu nexo originário com a verdade do Dasein (existência). Torna-se claro, neste ponto, que a verdade como descobrimento do ente remete-nos à dimensão originária do encobrimento do ser. Ao homem não basta simplesmente o conhecimento do que é mostrado (proposição, concordância, orthotes), pois pertence à sua constituição ontológica o estar aberto $(D a)$ ao silencioso, inesgotável, misterioso ou autovelante sentido do Ser (Sein). O ente é, porque sempre se dá a verdade inexaurível do Ser como diferença ontológica. A questão da verdade conduz-nos à experiência da compreensão do Ser como finitude, já que nunca temos o sentido ou desvelamento definitivos acerca do que conhecemos. A compreensão como possibilidade de ser é sempre pendente da situação hermenêutica ou visão histórica do Dasein (intérprete) (HEIDEGGER, 1989a, § 60. A estrutura existencial do poder-ser em sentido próprio, testemunhado na consciência, p. 89 ss.). O Dasein, entretanto, não determina a compreensão, pois esta acontece enquanto temporalidade (Zeitlichkeit) e historicidade (Geschichtlichkeit) que o abarca e supera (HEIDEGGER, 1989a, § 61 a 63, 69, 72 a 77, p. 93-110, 149-168, 176-212). O Dasein é histórico porque existe como ser-no-mundo. Assim, enuncia Heidegger: 
A análise da historicidade da pre-sença busca mostrar que esse ente
não é "temporal" porque "se encontra na história", mas, ao contrário,
que ele só existe e só pode existir historicamente porque, no fundo de
seu ser, é temporal. (HEIDEGGER, 1989a, \$72. A exposição
ontológico-existencial do problema da história, p. 181, itálicos do
autor).

E, mais adiante, complementa: "A tese da historicidade da pre-sença não afirma que é histórico o sujeito sem mundo, mas sim o ente que existe como ser-no-mundo. O acontecer da história é o acontecer do ser-no-mundo" (HEIDEGGER, 1989a, § 75. A historicidade da pre-sença e a história do mundo, p. 194, itálicos do autor.).

No escrito "A Essência da Verdade" ("Vom Wesen der Wahrheit"), datado de 1930, e inserido na obra Marcas do Caminho (Wegmarken) (HEIDEGGER, 2008, p. 189-214), Heidegger realiza o movimento lúdico de inversão (Kehre) da perspectiva do Dasein à perspectiva do próprio Ser. A obra Ser e Tempo visava preparar justamente esse momento em que as perspectivas mutuamente se implicassem produzindo a superação dialética da tradição metafísica ocidental. Nesse movimento ou mediação recíproca, acontece a Verdade como desvelamento ou liberdade do próprio Ser. Não mais o Ser tem lugar no Dasein, mas, ao contrário, o Dasein é quem tem lugar na Verdade do Ser. A irrupção do Ser (sempre maiúsculo indicando a sua dinâmica verbal) põe para existir o Dasein em relação com o ente e seu ser. Deste modo, o problema da verdade originária não está na relação entre o Dasein e o ente, mas se dá na correspondência do Dasein ao Ser ou, noutros termos, ao que Heidegger denomina a Clareira do Ser (Lichtung des Seins, Alétheia). A verdade é um acontecimento simultâneo de desvelamento e velamento do Ser. Não há antes uma essência ideal ou paradigmática da verdade, como proposta pela tradição platônica do conhecimento, isto é, um desvelamento definitivo, mas sim a verdade processual da essência como desvelamento (Unverborgenheit, Alétheia) que se funda no velamento (verborgenheit, léthe) do Ser. Noutras palavras, o desvelamento da verdade é a verdade do desvelamento, ou seja, o contínuo doar-se e retrair-se do próprio Ser. 
Obedecendo à circularidade da compreensão, Heidegger considera novamente o conceito tradicional acerca da essência da verdade salientando que "o verdadeiro, seja uma coisa verdadeira ou uma proposição verdadeira, é aquilo que está de acordo, o que concorda" (HEIDEGGER, 2008, p. 191). Essa verdade, divulgada pela escolástica medieval, traduz-se pela fórmula Veritas est adaequatio rei ad intellectus que pode significar, ao mesmo tempo, a adequação da coisa ao conhecimento (rei ad intellectum) e do conhecimento à coisa (intellectus ad rem). Os dois conceitos acerca da essência da veritas significam "um conformar-se com... e pensam, com isto, a verdade como conformidade" (HEIDEGGER, 2008, p. 192, itálico do autor).

Segundo Heidegger, tal definição da verdade como adaequatio rei ad intellectum deriva da crença teológica cristã segundo a qual as coisas não são senão criadas (ens creatum), correspondendo, assim, à ideia previamente concebida pelo espírito de Deus (intellectus divinus) (HEIDEGGER, 2008, p. 192-193). As coisas são "verdadeiras" porque são criadas (criaturas) em conformidade com a ideia divina. A mesma lógica da subordinação ou adequação entre o criador (Deus) e a criatura (coisa) encontra-se também na verdade da proposição ou enunciação humana (intellectus humanus) com respeito às coisas. Na visão teológica, os homens e as coisas, ou seja, as criaturas devem se conformar ou obedecer às leis do criador divino. Mas, nessa relação lógica, a verdade não se dá como processo de libertação, mas tão-somente como ato de submissão ou escravidão.

Visando superar a ideia teológica bem como a antropológica de um sujeito supremo que se impõe pela eliminação das diferenças, propõe Heidegger a meditação sobre a questão ontológica da verdade.

O que torna possível a concordância (Übereinstimmen) entre a enunciação (Aussage) e a coisa (Ding)? A apresentação (Vorstellung) realizada pelo Dasein, afirma Heidegger. A enunciação a-presenta (vor-stellt) a coisa assim como (so-wie) ela é. Noutras palavras, o a-presentar ou re-presentar (Vor-stellen) significa "o fato de deixar a coisa se contrapor enquanto objeto" (das Entgegenstehenlassen des Dinges als Gegenstand) (HEIDEGGER, 2008, 
p. 196). Explicita-se, neste ponto, a relação entre o sujeito enunciante e 0 objeto enunciado. $\mathrm{Na}$ apresentação, a coisa torna-se presente, ou seja, o ente se desvela diante de nós. Esta aparição da coisa (Dieses Erscheinen des Dinges), que se dá num encontro, "realiza-se no interior de um espaço aberto" (vollzieht sich innerhalb eines Offenen) (HEIDEGGER, 2008, p. 196). $\mathrm{Na}$ abertura, o ente aparece como é, e, somente assim, a enunciação (Aussage) se conforma com o ente (richtet es sich nach dem Seienden). A enunciação é um dito (Gesagte) que é "conforme, correto (verdadeiro)" [Das so Gesagte ist das Richtige (Wahre)] (HEIDEGGER, 2008, p. 197). Portanto, a concordância ou conformidade da enunciação à coisa só é possível pela abertura processual (Offenständigkeit) que se dá na relação entre ambos. Consequentemente, diz Heidegger, o conceito tradicional da verdade como adaequatio é insuficiente para caracterizar o ser do que aparece ou se apresenta. "A verdade não tem a sua morada originariamente na proposição" (Wahrheit ist nicht ursprünglich im Satz beheimatet) (HEIDEGGER, 2008, p. 197). A conformidade da proposição é a aparência da verdade, e não a aparição originária desta.

O Dasein só pode apresentar a proposição, que se verificará como verdadeira ou não, porque já está no interior da abertura que o mantém em relação com o objeto visado. Não somente a coisa aparece ou apresenta-se aberta ao Dasein, mas também este se abre ao ente, ou seja, deixa-se encontrar com ela. O Dasein existe (ex-siste) junto às coisas devido ao projeto ou abertura que os mantém em constante relação dialética. Deste modo, a questão ou investigação da verdade originária não pode se deter nas margens da adequação ou da inadequação, já que estas pertencem à concepção lógica da verdade como adaequatio intellectus ad rem, mas deve encaminhar-se à meditação ontológica de que o homem é mais chamado pela própria coisa, enquanto abertura da verdade, do que propõe definições sobre esta. A definição ou proposição do homem não esgota a excessividade misteriosa da própria abertura da Verdade do Ser. O dito é apenas uma resposta à questão inesgotável do Ser que se vela enquanto de desvela no ente com o qual o homem se encontra. $\mathrm{O}$ enunciado (dito) remete sempre à abertura silenciosa (não-dito) do ser como desvelamento da verdade. Pensada como Dasein, a essência do homem se dá como abertura $(D a)$ ao apelo ou questão da verdade 
originária do Ser (Sein). O homem existe, ou seja, está sempre fora de si, como ser-no-mundo. Em constante comércio com os entes, o homem insiste e, por muitas vezes, desiste no caminho da Verdade do Ser. O encontro e o desencontro do homem e das coisas acontecem sempre numa tensão dialética inquebrantável. Na dimensão originária da abertura, o homem desvela o ente ou a coisa e é, simultaneamente, desvelado por ela.

Mas, se a essência da verdade não se funda na conformidade da proposição, em que se funda? A abertura, diz Heidegger, que torna possível a conformidade funda-se na liberdade: "A essência da verdade é a liberdade" (Das Wesen der Wahrheit, als Richtigkeit der Aussage verstanden, ist die Freiheit) (HEIDEGGER, 2008, p. 198, itálicos do autor). Entretanto, importa assinalar que Heidegger não fala da essência no sentido metafísico de eternidade, mas na sua significação verbal ou processual. Nem tampouco a liberdade a que se refere é um domínio arbitrário da subjetividade humana. Com essa afirmação, Heidegger põe em questão a certeza corrente e cega de que a liberdade é uma propriedade do homem.

A essência da verdade implica a essência da liberdade que, por sua vez, põe o problema acerca da essência do homem. Noutras palavras, a existência humana enquanto Dasein, ou seja, abertura e possibilidade, articula-se no horizonte prévio da compreensão da verdade ou liberdade do Ser. A relação entre a verdade e a liberdade do Ser diz acerca da essência originária do homem (Cf. GUILEAD, 1965).

A liberdade é o fundamento da conformidade porque está ligada à essência originária da verdade. "A liberdade, pronuncia Heidegger, revela-se, então, como o que deixa-ser o ente (Freiheit enthüllt sich jetzt als das Seinlassen von Seiendem) (HEIDEGGER, 2008, p. 200). O deixar-ser (Seinlassen) não é uma omissão ou indiferença, mas o "entregar-se ao ente" (Sein-lassen ist das Sicheinlassen auf das Seiende) (HEIDEGGER, 2008, p. 200). De outro modo, deixar-ser ou entrar em diálogo, prossegue Heidegger, "significa entregar-se ao aberto e à sua abertura, na qual todo ente entra e 
permanece, e que cada ente traz por assim dizer consigo" (bedeutet, sich einlassen auf das Offene und dessen Offenheit, in die jegliches Seiende hereinsteht, das jene gleichsam mit sich bringt) (HEIDEGGER, 2008, p. 200). O aberto (offene) foi concebido na aurora do pensamento ocidental como $\tau \alpha \alpha \lambda \eta \theta \delta \alpha$, o desvelado (das Unverborgene). A Alétheia, traduzida por Heidegger como desvelamento do ente (Unverborgenheit des Seienden) visa repensar originariamente a questão da verdade esquecida do ser.

Nesse horizonte de compreensão, o deixar-ser, isto é, a liberdade é a exposição ao ente. Conseqüentemente, "a essência da liberdade, entrevista à luz da essência da verdade, aparece como ex-posição ao ente enquanto ele tem o caráter de desvelado" (Das auf das Wesen der Wahrheit hin erblickte Wesen der Freiheit zeigt sich als die Aussetzung in die Entborgenheit des Seienden) (HEIDEGGER, 2008, p. 201). A liberdade como o abandonar-se ao desvelamento do ente assinala a essência originária do homem. O homem (Dasein) existe (ex-siste), ou seja, ex-põe-se ao ente, entrega-se à abertura do ente saindo de si. O Dasein realiza-se como ser-no-mundo (In-der-Welt-sein). A existência humana é o constante abrir-se à Verdade do Ser. O homem não é senão enquanto correspondência à abertura (Alétheia) que desvela o ser de todos os entes. A existência humana é um diálogo com o desvelamento do ente em nome do velamento do Ser.

Heidegger diz-nos que a pergunta pelo desvelamento do ente enquanto tal e o começo da história (Geschichte) ocidental são uma e a mesma coisa (HEIDEGGER, 2008, p. 202). Assim, a liberdade como o deixar-Ser do ente não pertence ao arbítrio humano, não é uma recompensa ou objeto de conquista. Assinala o pensador: "O homem não 'possui' a liberdade como uma propriedade, mas antes, pelo contrário: a liberdade, o ser-aí ek-sistente e desvelador, possui o homem." (Der Mensch "besitzt" die Freiheit nicht als Eigenschaft, sondern höchstens gilt das Umgekehrte: die Freiheit, das eksistente, entbergende Da-sein besitzt den Menschen). (HEIDEGGER, 2008, p. 202.).

A liberdade como deixar-ser do ente realiza e efetua a essência da 
verdade sob a forma do desvelamento do ente. Consequentemente, a "verdade" não é uma conformidade da proposição enunciada por um "sujeito" com relação a um "objeto". A verdade, diz Heidegger, é o desvelamento do ente graças ao qual se realiza uma abertura (die Wahrheit ist die Entbergung des Seienden, durch die eine Offenheit west) (HEIDEGGER, 2008, p. 202). Toda a existência (ex-sistência) ou situação histórica do homem acontece, então, como a exposição a essa primordial abertura ou desvelamento do ente em sua totalidade. O homem é abertura $(D a)$, pois é possuído pela liberdade do Ser (Sein).

Mas, o homem, enquanto ex-sistência ou ex-posição ao ente, também pode, muitas vezes, não deixar que o ente seja tal qual é, pode encobri-lo em seu ser, fazendo predominar a aparência como verdade. Assim, a essência torna-se não-essência da verdade ou, noutros termos, a verdade torna-se nãoverdade. Heidegger chega mesmo a mostrar que a verdade e a não-verdade se copertencem e, só por isso, uma proposição verdadeira pode se opor com a correlativa proposição não-verdadeira (HEIDEGGER, 2008, p. 203).

A essência (desvelamento) e a não-essência (velamento), segundo Heidegger, constituem juntas a condição para se pensar mais profundamente a questão da verdade. A essência da verdade é a liberdade enquanto o deixarser ex-sistente que desvela 0 ente em sua totalidade e enquanto tal. $A$ liberdade dispõe previamente o Dasein em relação ao ente. A disposição (Stimmung) do Dasein não é uma categoria subjetiva, "estado de alma" ou sensação (Gefühl) do homem, mas, "uma ex-posição ek-sistente no ente na totalidade" (eine ek-sistente Ausgesetztheit in das Seiende im Ganzen) (HEIDEGGER, 2008, p. 204). Compreendendo ou não, todo o comportamento do homem já se dispõe em relação ao ente. Assim, acrescenta Heidegger, o deixar-ser do ente, a desocultação, é, em si mesmo, simultaneamente, uma ocultação (Das Seinlassen ist in sich zugleich ein Verbergen) (HEIDEGGER, 2008, p. 205).

A essência da verdade (desocultação) é a não-verdade (ocultação). Não se trata da verdade como adequação (adaequatio) e da não-verdade como 
inadequação da proposição à coisa, pois estas são oposições lógicas do senso comum, ou seja, verificações subjetivas. A verdade (Wahrheit) e a sua correspondente não-verdade (Un-wahrheit) são pensadas originariamente por Heidegger. Ambas mutuamente se implicam. O velamento (Die Verborgenheit) pertence à essência da verdade (Wahrheitswesen) como desvelamento (Entborgenheit). Assim, "o velamento do ente na totalidade, a não-verdade propriamente dita, é mais antiga do que toda manifestação de tal ou tal ente" (Die Verborgenheit des Seienden im Ganzen, die eigentliche Un-wahrheit, ist älter als jene Offenbarkeit von diesem und jenem Seienden) (HEIDEGGER, 2008, p. 205). A não-verdade (Un-wahrheit), a não-essência (Un-wesen), o não-desvelamento (A-létheia) constituem a dimensão originária do Ser, sempre pressuposta, de toda verdade, essência e desvelamento do ente. Voltamos a pensar novamente na estrutura prévia da compreensão inerente a todo questionamento acerca da verdade do Ser. O descobrimento do ente particular como conformidade da enunciação (o dito) pressupõe o encobrimento do ente enquanto tal e em sua totalidade (o não dito). Anterior à verdade predicativa do ente (desvelamento), encontra-se a verdade originária do ser. Em todo é já se pressupõe o dar-se da verdade como compreensão inesgotável e misteriosa do ser. Heidegger diz que a dissimulação ou ocultação do ente como tal não é senão o mistério (das Geheimnis) que domina o Da-sein do homem. Prosseguindo, afirma: "Enquanto ek-siste o ser-aí instaura o primeiro e o mais amplo não-desvelamento, a não-verdade propriamente dita. A não-essência propriamente dita da verdade é o mistério" (Das Da-sein verwahrt, sofern es eksistiert, die erste und weitest Un-entborgenheit, die eigentliche Un-wahrheit. Das eigentliche Un-wesen der Wahrheit ist das Geheimnis) (HEIDEGGER, 2008, p. 206). E, mais adiante, revela: o "não" (Un-) da não-essência original da verdade (Un-wesens der Wahrheit) como não-verdade (Un-wahrheit) aponta para o âmbito (Bereich) ainda não experimentado e inexplorado da verdade do ser (Wahrheit des Seins) e não apenas do ente (Seienden) (HEIDEGGER, 2008, p. 206). A Alétheia (desvelamento) é pensada a partir do mistério do velamento (léthe).

O homem relaciona-se a entes particulares, mergulha numa realidade dada e ocupa-se constantemente com as coisas ordinárias do cotidiano. 
Consequentemente, produz-se o esquecimento do mistério. Mas, esse mistério esquecido do Dasein não é eliminado pelo esquecimento. O retraimento do mistério já de si é o ocupar-se do homem na vida ordinária e progressiva.

Agarrando-se à certeza do ente que diariamente encontra na forma social, política ou religiosa, o homem demasiado humano insiste no esquecimento do mistério do Ser. Segundo Heidegger, "o ser-aí não apenas ek-siste, mas ao mesmo tempo in-siste, isto é, petrifica-se apoiando-se sobre aquilo que o ente, manifesto como que por si e em si mesmo, oferece" (das Dasein nicht nur ek-sistiert, sondern zugleich in-sistiert, $d$. h. sich versteifend auf dem besteht, was das wie von selbst und an sich offene Seiende bietet) (HEIDEGGER, 2008, p. 208, itálico do autor). De nada adianta se ocupar do esclarecimento ou explicação total do ente, quando se esquece do misterioso Ser que se retrai no desvelamento. Esquecer o Ser e abandonar a existência concreta no horizonte do tempo interagem continuamente. Ambos traduzem-se hoje no culto demasiado da subjetividade do ente, do futuro como descarte e do fingimento e da trapaça como modos de ação numa sociedade inautêntica. Tendo esquecido o caminho da experiência do Ser, o homem perde-se nas armadilhas de um mundo doente e tecnocrático, constantemente maquiado. Mesmo assim, o mistério sempre reclama a atenção do homem. Portanto, por insistir nas verdades particulares, o homem esquece a primordial Verdade do Ser.

Insistindo no comércio com os entes, o homem erra (Der Mensch irrt) (HEIDEGGER, 2008, p. 208). A errância (Die Irre) não é um desconhecimento, mas pertence à "constituição íntima do ser-aí" (inneren Verfassung des Daseins) (HEIDEGGER, 2008, p. 208). Noutras palavras, "a errância é o espaço de jogo deste vaivém, no qual a ek-sistência in-sistente se movimenta constantemente, se esquece e se engana sempre novamente" (Die Irre ist der Spielraum jener Wende, in der die in-sistente Ek-sistenz wendig sich stets neu vergißt und vermißt) (HEIDEGGER, 2008, p. 208). O erro, na concepção heideggeriana, não é a ausência de conformidade do juízo, a falsidade do conhecimento ou, conforme a pregação diária e enfadonha, a noção cristã de pecado. É no jogo recíproco de desvelamento e velamento ou na tensão 
dialética dos contrários que se afirma a errância.

O mistério da errância é o desgarrar-se da existência que insiste em suas certezas subjetivas no senso comum que apela à evidência do ente revelado, e olvida-se da Verdade do Ser. O desvelamento do ente particular já de si é a errância enquanto velamento do ente em sua totalidade. Descobrir é encobrir, pois o ser se retrai enquanto se desvela no ente. Assim, a errância enquanto não-verdade pertence à essência originária da verdade. Anterior à oposição lógica, dá-se a verdade originária do ser como tensão dialética dos contrários (velamento e desvelamento).

A questão hermenêutica da verdade visa mostrar que não é a subjetividade humana, que se afirma em toda proposição ou enunciação acerca do ente e obnubila o ser, quem decide ou detém o domínio sobre o desvelamento da Verdade originária do Ser (A-létheia). A Verdade do Ser, enquanto tensão dialética de iluminação e encobrimento, possibilita a abertura da existência humana ao misterioso silêncio do Ser.

O desvelamento da verdade pressupõe a verdade do desvelamento. Portanto, a fraternidade dos contrários edifica-se na questão radical do Ser. Heidegger observa que a questão sobre a essência da verdade origina-se da questão sobre a verdade da essência. Enquanto a essência da verdade limitase a uma idealidade, "generalidade" ou universalidade "abstrata" do conhecimento, "a questão da verdade da essência entende essência em sentido verbal e pensa, nesta palavra, [...] o seer (Seyn) como a diferença que impera entre ser e ente". (Die Frage nach der Wahrheit des Wesens versteht Wesen verbal und denkt in diesem Wort [...] das Seyn als den waltenden Unterschied von Sein und Seiendem) (HEIDEGGER, 2008, p. 213)

Verdade significa o velar iluminador como rasgo fundamental do Ser (Wahrheit bedeutet lichtendes Bergen als Grundzug des Seyns). A questão da essência da verdade encontra sua resposta, diz Heidegger, na proposição: "a essência da verdade é a verdade da essência" (das Wesen der Wahrheit ist die Wahrheit des Wesens) (HEIDEGGER, 2008, p. 213, itálicos do autor). 
Nessa proposição, o sujeito não é o homem que enuncia algo acerca de um ente, mas a verdade da essência. A verdade não pertence ao homem (Dasein), mas o homem é quem pertence à questão da verdade do desvelamento e do velamento processual do Ser. Por fim, Heidegger enuncia:

\begin{abstract}
A resposta à questão acerca da essência da verdade é a dicção de uma viravolta no interior da história do seer. Porque ao seer pertence o velar iluminador, ele aparece inicialmente à luz da retração que encobre. O nome desta Clareira é $\alpha \lambda \eta \theta \varepsilon l \alpha$. (Die Antwort auf die Frage nach dem Wesen der Wahrheit ist die Sage einer Kehre innerhalb der Geschichte des Seyns. Weil zu ihm lichtendes Bergen gehört, erscheint Seyn anfänglich im Licht des verbergend Entzugs. Der Name dieser Lichtung ist $\alpha \lambda \eta \theta \varepsilon t \alpha$ ) (HEIDEGGER, 2008, p. 213).
\end{abstract}

O sentido da verdade como irrupção ou desvelamento (Alétheia, Clareira) do Ser foi, no entanto, encoberto e esquecido com o advento da filosofia platônica. Segundo Heidegger, no texto "Identidade e Diferença" ("Identität und Differenz"), datado de 1957, e presente na obra Conferências e Escritos Filosóficos (HEIDEGGER, 1989b, p. 137-162), começa a época do "esquecimento" (Vergessenheit) do ser, que não é senão o esquecimento "da diferença entre o ser e o ente" (der Differenz zwischen dem Sein und dem Seienden) (HEIDEGGER, 1989b, p. 153, itálico do autor).

Assim, desde Ser e Tempo às últimas obras, a tarefa do pensamento heideggeriano é a questão hermenêutica da verdade como possibilidade de superação (Verwindung) dialética da concepção ou história metafísica do ser, que se introduziu com a idealidade platônica, enraizou-se com a subjetividade cartesiana e culminou com a inversão axiológica nietzscheana. Noutras palavras, é em memória (Andenken) do acontecimento originário da Verdade do Ser (Alétheia, Lichtung, Ereignis) que se põe a caminho o pensamento de Martin Heidegger. (Cf. PÖGGELER, 2001).

No escrito "A teoria platônica da verdade" ("Platons Lehre von der Wahrheit"), datado de 1931/1932, 1940, e inserido também na obra Marcas do Caminho (Wegmarken) (HEIDEGGER, 2008, p. 215-250), Martin Heidegger 
afirma que Platão inaugura, na República (Livro VII, 514 a, 2 até 517 a, 7), a história metafísica do ser realizando a mudança na determinação da essência da verdade, ou seja, transformando o desvelamento (Alétheia) em exatidão (Orthotes) do olhar à ideia do Bem (Ágathon). Nesse sentido, "Verdade torna-

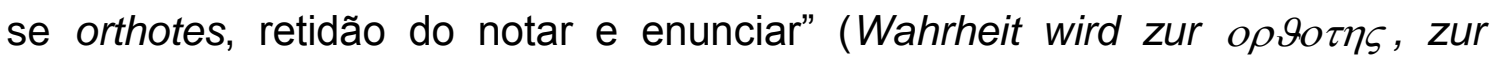
Richtigkeit des Vernenhmens und Aussagens) (HEIDEGGER, 2008, p. 242). Essa caracterização da verdade platônica é, ao mesmo tempo, o início do "humanismo" ocidental europeu, pois cada vez mais enfatiza a perspectiva do ente humano em detrimento da perspectiva do ser. Assim, concebe-se a formação (Paideia) humana como o olhar voltado em direção à idealidade suprema do conhecimento. E, até mesmo em Nietzsche, que consuma a história da metafísica, definindo a verdade como inexatidão (Unrichtigkeit), verifica-se a influência platônica segundo a qual mostra-se "a essência da

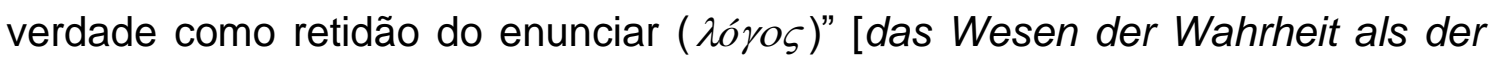

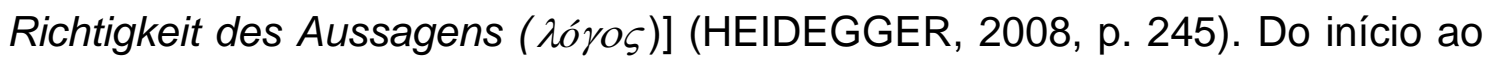
fim, de Platão a Nietzsche, o Ocidente vive sob o signo do nilismo metafísico, da existência não enraizada na estrutura sensível e temporal. Mas, dessa mesma situação brota a exigência ou o apelo de nascimento de um "novo princípio, gesto e transformação" do pensamento. Nessas palavras do poeta Rilke, revela-se toda a hermenêutica heideggeriana.

O idealismo platônico, ao decretar o imperativo axiológico do conhecimento, dá início à tradição metafísica que se fundamenta na divisão (Khorismós) do mundo inteligível (luz) e do mundo sensível (sombra). Essa divisão ou separação é responsável pelas oposições lógicas do corpo e da alma, da vida e da morte, da realidade e da idealidade, do sujeito e do objeto. Tanto o cristianismo quanto o cientificismo são filhos prediletos do platonismo. Até mesmo a experiência da arte, da história e da linguagem foi modificada, durante muito tempo, por ela. Separaram-se a arte e a existência, o passado e o presente, as palavras e as coisas. Platão condenou a arte ao dizer que ela não percorre o caminho do conhecimento, não visa à essência verdadeira das coisas e, por isso, cria imagens enganosas e ilusórias (Rep. 511 e 602a) (Cf. GRASSI, 1975, A Condenação da Arte. Platão, p. 91-117). A história reduziu-se 
à mera reprodução dos fatos, ao culto dos mortos, e a linguagem tornou-se apenas instrumento de conceitualização, veículo de uma verdade paradigmática. Ao separar a realidade inferior (mundo sensível terrestre) da idealidade superior (mundo inteligível celeste), o platonismo negou a pátria da existência humana, ou seja, o mundo concreto da vida foi reduzido à aparência e ao não-ser. Privilegiado era só, então, o mundo do ser supremo, da essência ideal, da verdade paradigmática. A experiência terrestre não é senão obscura e ilusória e só atinge a verdade do conhecimento quando volta o olhar para a claridade celeste. $O$ mundo da verdade platônica é o inteligível e nunca 0 sensível. Pode-se afirmar que o ser como presença constante ou fundamento supremo só se legitima na separação lógica dos contrários. Deste modo, a interpretação normativa do ser como presença constante ou imutável demonstra que Platão não fala da essência do próprio ser, mas somente da idealidade do ser de todos os entes intramundanos. Ao homem só cabe a obediência do olhar e a entrega da alma ao ideal supremo do conhecimento (Cf. SOUZA, 1988, O Mitologema Platônico da Idealidade, p. 2-23). O platonismo é a esperança do mundo e do homem ideais ou, em outras palavras, o ser platônico é o deixar de viver no horizonte do tempo. Já se prevê em Platão toda a filosofia inversa de Nietzsche: o sensível deve predominar, e não o inteligível.

Na Modernidade, a contrapartida à metafísica da idealidade platônica é a metafísica da subjetividade cartesiana, conforme anuncia Martin Heidegger na obra Nietzsche II (Nietzsche: Der Europäische Nihilismus) (HEIDEGGER, 2007b, O domínio do sujeito na modernidade, p. 104-109). A relação subordinativa do ser supremo e do ente intramundano (platonismo) converte-se no predomínio da visão do sujeito com respeito ao objeto visado (cartesianismo). Enquanto o ser platônico é absoluto, imutável, a priori, o ser cartesiano é relativo, ou seja, é a condição dos objetos. Mas tanto um quanto o outro não abandonam a noção de um sujeito supremo, de algo que subjaz como fundamento dos entes. Os Tempos Modernos demitem a ideia divina e entronizam o homem como certeza subjetiva, ou seja, como o paradigma do conhecimento verdadeiro de todos os entes (HEIDEGGER, 2007b, Metafísica e antropomorfismo, p. 94-99). A realidade torna-se a constante objetivação da 
subjetividade humana. Não mais a divindade, porém o homem é a força ditadora do destino. A essência da verdade não reside mais no mundo inteligível, mas no mundo sensível e visível da humanidade, na percepção humana como medida de todas as coisas. A subjetividade do sujeito determina a objetividade de todos os objetos. A visão de mundo cartesiana transforma todos os entes em objetos da subjetividade. Nesse sentido, a filosofia dos tempos modernos só foi possível graças à manutenção e, sobretudo, à inversão da divisão (Khorismós) platônica do mundo inteligível (ideal divino) e do mundo sensível (real humano). No horizonte da subjetividade, há a separação do real e do ideal. O sujeito humano está cindido entre o "eu" ideal e o "eu" real. Noutros termos, a essência da verdade cartesiana não é a idealidade, mas a subjetividade imperial.

Segundo Heidegger, a metafísica cartesiana do ego cogito, ergo sum introduz uma nova determinação da essência da verdade, que se traduz na mudança do paradigma divino para o paradigma humano do conhecimento (HEIDEGGER, 2007b, O cogito cartesiano como cogito me cogitare, p. 109117). O homem liberta-se dos ditames do ser supremo e se impõe como o fundamento (subiectum) de todo ser e pensar. A idealidade divina (teocentrismo platônico) dá lugar à subjetividade humana (antropocentrismo cartesiano). A nova visão de mundo reduz todos os entes à subjetividade dominante. Nesse sentido, repete-se o regime de subordinação através da percepção humana. A subjetividade torna-se o fundamento e o poder da verdade da arte, da história e da linguagem. A verdade como experiência do ser converte-se, então, na ciência e na consciência do ente (ego) humano. Assim, a subjetividade articula-se no conhecimento, na afetividade, na vontade e na imaginação. Mais precisamente, a correlação da subjetividade e da objetividade constitui o fundamento da modernidade cartesiana. A subjetividade (o cogitare) não é, assegura Heidegger, só o conhecer, mas também o querer, o imaginar e o sentir. Cogitare é a representação do homem em todo objeto representado. A subjetividade implica a objetividade. O ego humano é a representação ou condição de existência de todos os entes. Noutros termos, a metafísica da subjetividade é a certeza do ente ou a representação humana de todo conhecimento objetivo (Cf. SOUZA, 1988, O Filosofema Cartesiano da 
Subjetividade, p. 24-37). Logo, a oposição do sujeito e do objeto é a réplica moderna da separação platônica do sensível e do inteligível. A subjetividade cartesiana é o mundo cindido entre o ideal (eu-sujeito) e o real (eu-objeto). $O$ primeiro permanece constante e imutável, porém o segundo não. A verdade cartesiana é a certeza do ente que permanece em detrimento do que desaparece. A certeza ou a representação humana obscurece, assim, o ser como desvelamento autovelante.

Nietzsche consuma a metafísica ocidental europeia ao desconstruir o fundamento do platonismo promovendo a sua radical inversão axiológica, conforme anuncia Martin Heidegger na obra Nietzsche I (Nietzsche: De Wille zur Macht als Kunst) (HEIDEGGER, 2007a, A inversão nietzschiana do platonismo, p. 178-187). Este é o objetivo primordial de sua obra $A$ Vontade de Poder (Der Wille zur Macht) (Cf. NIETZSCHE, 2008). Assim, a crítica mordaz que elabora contra o cristianismo (o platonismo para o "povo"), contra a existência submetida ao império da escravidão e da resignação, contra o abandono da morada humana sobre a Terra e da extraordinária alegria da vida, faz de Nietzsche o pensador que mais abalou a estrutura da metafísica ocidental europeia justamente porque destruiu ou desconstruiu a sua essência onto-teo-lógica. Ao declarar a morte de Deus (Cf. HEIDEGGER, 2002a, A palavra de Nietzsche "Deus morreu" (1943), p. 241-305), Nietzsche reconhece que o valor supremo da humanidade já não mais se efetiva, pois o mundo cristão é o culto e o comércio de um cadáver, de uma vida que jamais se realiza na estrutura temporal e concreta da existência. $O$ abandono do mundo e dos laços vitais, a lamentação do tempo e do lugar paradisíacos sobre a face da Terra constituem o niilismo europeu e, por isso, são o alvo da crítica nietzscheana. Visando superar o valor supremo perdido, propõe novos valores. Mas, ao estabelecer a equivalência entre o ser e o valor, permanece Nietzsche pactário da mesma tradição metafísica que combatia (Cf. HEIDEGGER, 2007b, A metafísica de Nietzsche, p. 195-253). A inversão axiológica, ou seja, a ênfase na estrutura passional (sensível, corporal, dionisíaca) não é senão o platonismo (culto demasiado do inteligível, espiritual, apolíneo) às avessas. A metafísica de Nietzsche propõe o niilismo, ou seja, a destruição dos valores supremos como forma de construção de novos valores. Invertendo o platonismo, 
Nietzsche baseia todo o seu pensamento sobre o sensível como arma de combate à abstração do inteligível ou supra-sensível platônico (Cf. SOUZA, 1988, O Ideologema Crítico da Modernidade, p. 113-130; Idem, 2000, Poesia e filosofia em Nietzsche, p. 247-251.). Nesse âmbito, a relação entre o platonismo e o niilismo é, ao mesmo tempo, a consumação e a possibilidade de superação da tradição metafísica ocidental (Cf. SOUZA, 1988, O Platonismo e o Niilismo, p. 131-175).

Nietzsche repensa, conseqüentemente, a discórdia platônica entre a arte e a verdade (Cf. HEIDEGGER, 2007a, Esfera e contexto da meditação platônica sobre a relação entre arte e verdade, p. 147-154). Combatendo o inteligível (a verdade), propõe o sensível (a arte) como fundamento da existência humana. Como apenas inverte Platão, não chega a eliminar a discórdia, mas tão-somente a privilegiar um dos lados, a saber, o da arte. Defende, portanto, o que Platão condenava, na República (X, 595 a até 621 d), como imitação (Mimesis) e ilusão enganosas que não chegam a atingir a verdade (idéa) paradigmática do conhecimento (Cf. HEIDEGGER, 2007a, A república de Platão: $O$ distanciamento da arte (mimese) em relação à verdade (ideia), p. 154-168). Em um ou outro caso, privilegiando ou desprivilegiando o inteligível, ou seja, a interpretação do ser como $\varepsilon l \delta o \varsigma$, impensado continua o fato de que esta pressupõe a interpretação da verdade como $\alpha \lambda \eta \theta \varepsilon ı \alpha$ (desvelamento). Somente nessa estrutura prévia da compreensão do ser acontece o jogo dialógico da arte e da verdade.

Resumindo, podemos colocar os seguintes pontos acerca da questão hermenêutica da verdade: 1 . Primeiramente, a verdade originária manifestouse como desvelamento (Alétheia) ou acontecimento poético do próprio ser. Assim se verifica no pensamento de Heráclito e Parmênides; 2. No entanto, esse sentido da verdade como desvelamento foi logo encoberto e esquecido com o advento da filosofia platônica. O desvelamento (Alétheia) converte-se em exatidão ou conformação (Orthotes), ou seja, adequação do conhecimento do ente à idealidade suprema. Funda-se a tradição onto-teo-lógica da metafísica ocidental. A verdade do ser (A-létheia) transforma-se em retidão do 
juízo ou proposição do sujeito. A verdade não é mais perspectiva do ser, mas a perspectiva do sujeito do conhecimento. Funda-se o humanismo ocidental, cujo pai é Platão, como o subjetivismo do ente que obscurece cada vez mais a verdade como fenômeno originário de realização do ser no tempo. Importa tãosomente a maneira correta ou adequada de se olhar o ente. Segundo Platão, a verdade não reside na alteridade sensível, mas na inteligibilidade ou contemplação $(i \delta \varepsilon l v)$ da ideia suprema do Bem. A verdade é a idealidade imutável do ser, isto é, o saber definido acerca do ser dado pela perspectiva dominadora do sujeito. Logo, a verdade como normatividade do saber ideal do sujeito esquece o ser. $O$ esquecimento implica a ascensão do subjetivismo ou, de outro modo, da metafísica da subjetividade. A verdade é a proposição do ente, e não mais a desocultação do ser. Sendo a verdade não compreendida a partir do ser, importa assinalar que a metafísica ocidental europeia é, de Platão a Nietzsche, segundo Heidegger, fundamentalmente humanismo ou niilismo, pois se atém simplesmente ao ente esquecendo o Ser (Cf. HEIDEGGER, 1967; Idem, 2007b, O niilismo europeu, p. 21-193); 3. A desconstrução da idealidade platônica foi colocada de forma radical por Nietzsche que, entretanto, continua ligado à mesma tradição metafísica que combatia quando promove a inversão dos valores supremos. Nietzsche é, nas suas próprias palavras, "um Platão às avessas". O niilismo de Nietzsche é a consumação da história e da metafísica da subjetividade moderna e, consequentemente, o esquecimento da verdade originária do próprio Ser em nome da perspectiva do ente como vontade de potência.

Visando à superação dialética (Verwindung) da tradição metafísica da subjetividade, Heidegger pensa hermeneuticamente a questão inédita da Verdade do Ser como des-velamento (A-létheia) ou Clareira (Lichtung). Deste modo, a verdade, o homem e a linguagem não são compreendidos em sua essência metafísica, mas sim em sua existência originária à questão do Ser. Começa a se desocultar o horizonte segundo o qual a verdade da arte será por nós tratada, quer dizer, somente superando o subjetivismo ou a tradição do platonismo, do fundamento externo ou interno ao ente, a questão ou o jogo da arte e da verdade desoculta-se em sua dimensão originária. Noutras palavras, a Verdade do Ser como des-velamento acontece na dimensão poética da 
linguagem. Configura-se, assim, o intercâmbio da compreensão, da verdade e da linguagem do ser como o próprio jogo da obra de arte. Nesse sentido, afirmamos, na segunda parte de nossa tese, que somente a questão hermenêutica da Verdade do Ser como des-velamento (A-létheia) fala originariamente acerca da escrita da morte na narrativa dramática $O$ Risco do Bordado, de Autran Dourado.

A investigação heideggeriana acerca da questão originária da verdade do ser como superação da tradição metafísica ocidental (platonismo) repensa, simultaneamente, a essência originária do homem e da linguagem. Noutras palavras, a relação do homem e do ser dá-se por intermédio do acontecimento da linguagem, e não simplesmente através da subjetividade.

Ao determinar a verdade como adequação ou conformidade da proposição (Orthotes), o platonismo subjuga o evento ou acontecimento poético da linguagem como verdade (Alétheia) originária do ser. A linguagem não mais faz brotar ou irromper, mas tão somente conformar o ser ao ideal supremo do conhecimento. A existência platônica torna-se o cárcere do ser, do homem e da linguagem.

Já em Ser e Tempo, Heidegger mostra a relação ou pertinência recíproca da compreensão e da linguagem do ser. A compreensão é o próprio acontecer da linguagem como "pronunciamento do discurso" (Die Hinausgesprochenheit der Rede) (HEIDEGGER, 1988b, § 34. Pre-sença e discurso. A linguagem, p. 219). Nesse contexto, a linguagem tem o seu "lugar" ontológico, diz Heidegger, na constituição ontológica do Dasein.

O Dasein caracteriza-se por ter linguagem, não porque seja um animal racional, mas sim porque só se realiza descobrindo o mundo e a si mesmo na linguagem. Discursando ou questionando, o homem é guiado pela verdade do ser. Nesse sentido, o modo de ser originário da linguagem não é o de mero instrumento, mas o de revelação do ser. Importa a linguisticidade (Sprachlichkeit) do ser, ou seja, a experiência do ser na linguagem, e não simplesmente a ciência do ser (linguística) como lógica gramatical. Segundo 


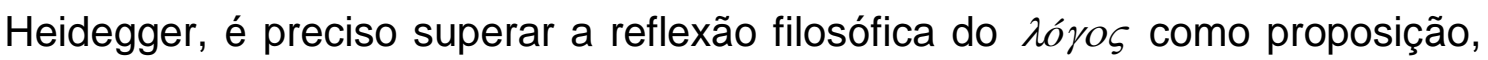
isto é, lógica gramatical, caso se queira resgatar o sentido primordial da linguagem.

Nas obras posteriores, principalmente a partir de Sobre o humanismo (Brief über den Humanismus), publicado em 1946, Heidegger realiza o movimento duplo e simultâneo da relação entre o Dasein e a linguagem (Cf. HEIDEGGER, 1967). Quer dizer, não é a linguagem que tem lugar no Dasein, mas o Dasein é que tem o seu lugar na linguagem. A linguagem do ser é que põe em jogo o Dasein, e não o contrário. O homem jamais consegue dominar a compreensão, a verdade ou a linguagem originária do próprio ser.

Não há domínio porque o modo de ser próprio do homem é a exsistência (Ek-sistenz), ou seja, o abrir-se à possibilidade do ser. Somente enquanto insiste, o homem existe concretamente e partilha a verdade segundo a qual a existência é a contínua aprendizagem do ser no horizonte finito do tempo. A sabedoria humana é a experiência ou reconhecimento da finitude como possibilidade de ser. Expondo-se, o homem acolhe o apelo ou verdade originária do ser como acontecimento da linguagem. Assim, nas palavras de Heidegger: "A linguagem é o advento do próprio Ser que se clareia e se esconde" (Sprache ist lichtend-verbergende Ankunft des Seins selbst) (HEIDEGGER, 1967, p. 45). O homem não é o sujeito nem o objeto, mas o projeto lançado pelo próprio Ser na Verdade do Ser. Ex-sistindo nesse lançamento, o homem guarda a Verdade do Ser. Em resumo, o homem não é o dominador, mas, originariamente, "o pastor do Ser" (Der Mensch ist der Hirt des Seins) (HEIDEGGER, 1967, p. 51). Somente desse modo é possível reconhecer que "a linguagem é a linguagem do Ser, como as nuvens são as nuvens do céu" (Die Sprache ist so die Sprache des Seins, wie die Wolken die Wolken des Himmels sind) (HEIDEGGER, 1967, p. 100).

Heidegger afirma, cada vez mais, que o horizonte histórico da compreensão do ser funda-se na linguagem, e não no humano demasiado humano. Essa perspectiva encontra-se de forma radical em sua obra $A$ Caminho da Linguagem (Unterwegs zur Sprache), publicada em 1959. Nela 
enuncia-se a essência originária da linguagem do ser: " $A$ linguagem fala" (Die Sprache spricht) (HEIDEGGER, 2003, A linguagem, p. 9, itálicos do autor). Ela não é, portanto, o veículo da subjetividade humana, mas, primordialmente, o acontecimento ou desvelamento do ser.

A linguagem fala ao homem não como signo de uma realidade previamente estabelecida, mas, sobretudo, como "a música do silêncio" ou "a consonância do quieto" (das Geläut der Stille) (HEIDEGGER, 2003, A linguagem, p. 24, itálicos do autor). Quer dizer: o homem sofre, primordialmente, o apelo silencioso do ser e, só assim, chega a corresponder ou dialogar com ele. Conforme Heidegger, "O homem fala à medida que corresponde à linguagem. Corresponder é escutar. Ele escuta à medida que pertence ao chamado da quietude." (Der Mensch spricht, insofern er der Sprache entspricht. Das Entsprechen ist Hören. Es hört, insofern es dem Gehei $\beta$ der Stille gehört) (HEIDEGGER, 2003, A linguagem, p. 26).

Segundo Heidegger, "a essência da linguagem" (Das Wesen der Sprache) é "a linguagem da essência" (Die Sprache des Wesens) (HEIDEGGER, 2003, A essência da linguagem, p. 136), ou seja, a linguagem do constante originar-se do ser. Não se trata, evidentemente, da essência metafísica do ser como presença constante, mas da essência originária. 0 homem sofre "a experiência da linguagem como a saga do dizer" (die Erfahrung der Sprache als der Sage) (HEIDEGGER, 2003, A essência da linguagem, p. 159). Porém, o que significa dizer (Sagen)? No texto "O caminho para a linguagem”, Heidegger responde: “'Sagan', a saga do dizer significa: mostrar, deixar aparecer, deixar ver e ouvir" ("Sagan" heißt: zeigen-, erscheinen-, sehen- und hören-lassen) (HEIDEGGER, 2003, O caminho para a linguagem, p. 202, itálico do autor). O dizer pertence ao ser e não ao homem, que é somente quem se põe à escuta do silencioso apelo do sentido ou da verdade do ser. Logo, importante é não esquecer o acontecimento poético segundo o qual "a linguagem fala dizendo, ou seja, mostrando" (Die Sprache spricht, indem sie sagt, d.h. zeigt) (HEIDEGGER, 2003, O caminho para a 
linguagem, p. 203) o ser em seu movimento de velamento e desvelamento simultâneos.

A linguagem como a voz ou o dizer (das Sagen) do ser, ou seja, o apelo que se dirige ao homem e exige a sua correspondência, será considerada por Hans-Georg Gadamer, como veremos no capítulo 2, como o horizonte da experiência hermenêutica que se efetiva entre 0 homem e 0 mundo, 0 intérprete e o texto.

\subsection{A poesia originária da arte}

Martin Heidegger, dando continuidade à desconstrução dialética da Metafísica Ocidental, investiga, em A Origem da Obra de Arte [Der Ursprung des Kunstwerkes (1935/1936)], a essência originária ou poética da obra de arte. Assim, segundo o eminente pensador, a essência originária da arte é "o pôr-se em obra da verdade do sendo" " (das Sich-ins-Werk-Setzen der Wahrheit des Seienden) (HEIDEGGER, 2010, A coisa e a obra, p. 87). Na obra, acontece o desvelamento do ser de todos os entes. Desvelamento dos entes (die Unverborgenheit des Seiendes), assinala Heidegger, é o que os gregos chamam $\alpha \lambda \eta \theta \varepsilon i \alpha$ (Alétheia). Portanto, o desvelamento não é senão 0 acontecimento da verdade (Geschehen der Wahrheit) na obra.

A essência da arte não é a verdade como concordância (Orthotes Platônica) ou imitação fotográfica do real. A obra não imita o realizado ou originado (o sujeito ou o objeto), mas o realizar-se ou originar-se das coisas, a operatividade lúdica em que se dá o velamento e o desvelamento simultâneos do ser de todos os entes.

\footnotetext{
${ }^{1}$ Manuel Antônio de Castro, em sua apresentação à obra de Heidegger (2010, p. XXVIIXXVIII), esclarece-nos que traduziu a palavra alemã "Das seiende" por "sendo" e não por "ente", como seria o esperado. "Sendo" corresponderia à palavra grega "on", particípio presente do verbo "einai", trazendo em si uma ambigüidade originária acerca do "princípio do limite e do não-limite", que foi perdida ao ser traduzida para o latim por "ens, entis", de onde se formou a palavra portuguesa "ente". Por isso, o "on" é originariamente uma "dobra", e nele está todo o enigma que é a obra de arte segundo Heidegger.
} 
Por conseguinte, "o originário da obra de arte é a arte" (Der Ursprung der Kunstwerkes ist die Kunst) (HEIDEGGER, 2010, A obra e a verdade, p. 97), e não o artista ou a obra. Somente por intermédio da arte chegam a existir 0 artista e a obra. Segundo Heidegger, a obra tem o caráter de coisa, não no sentido de um ente cujo ser é matéria formada, objeto confeccionado ou utilidade, mas no sentido originário de símbolo. Assim, não se pode pensar a origem da obra quando esta é concebida como uma coisa ou um ente cujo ser é repleto de características, sensações ou é simplesmente matéria conformada (HEIDEGGER, 2010, A coisa e a obra, p. 45-97). Noutros termos, a obra não é um objeto que se submete à perspectiva dominadora do sujeito. A sua origem não está nas proposições ou habilidades manuais do artista. Nesse sentido, jamais se reduz a um artesanato ou utilidade. A origem da obra é a arte.

$\mathrm{Na}$ obra, não se fabricam objetos, mas se desvela o ser de todos os entes, ou seja, nela a essência originária da arte não é senão acontecimento da verdade como desvelamento (Alétheia) dos entes (HEIDEGGER, 2010, A obra e a verdade, p. 97-145). A essência da arte não consagra a subjetividade ou objetividade do autor, porque é a auto-representação do próprio modo de ser da obra de arte.

Heidegger pergunta pelo ser-obra (Werksein) da obra e responde: "Serobra significa: instalar um mundo" (Werksein heißt: eine Welt aufstellen) (HEIDEGGER, 2010, A obra e a verdade, p. 109). O mundo da obra não é uma soma de partes ou um conjunto de objetos visíveis, mas a abertura primordial do sentido em que tudo se encontra e desencontra, vive e morre. O mundo ou abertura é apenas um traço essencial do modo de ser da obra. O outro é o seu retrair-se, ou seja, o seu ocultar-se como remissão ao seio materno da terra. Dessa maneira, prossegue Heidegger: "No que a obra instala um mundo, elabora a Terra" (Indem das Werk eine Welt aufstellt, stellt es die Erde her) (HEIDEGGER, 2010, A obra e a verdade, p. 115). Mais adiante, afirma: "A Terra é essenciamente a que se fecha-em-si. Elaborar a Terra significa: trazêla ao aberto como a que se fecha a si mesma. (Die Erde is das wesenhaft 
Sichverschließend. Die Erde her-stellen heißt: sie ins Offene bringen als das Sichverschlie- $\beta$ ende) (HEIDEGGER, 2010, A obra e a verdade, p. 117).

Portanto, o mundo e a Terra co-pertencem à estrutura dinâmica ou lúdica, ou seja, à "unidade do ser-obra" (Einheit des Werkseins) (HEIDEGGER, 2010, A obra e a verdade, p. 119) e, embora diferentes entre si, nunca estão separados. O mundo fundamenta-se sobre a Terra, e a Terra irrompe enquanto mundo (Die Welt gründet sich auf die Erde, und Erde durchragt Welt) (HEIDEGGER, 2010, A obra e a verdade, p. 121). Quer dizer, o modo de ser próprio da obra de arte é a unidade ou tensão harmônica dos contrários mundo e Terra. Somente assim pode Heidegger afirmar-nos: "O confronto de Mundo e Terra é uma disputa" (Das Gegeneinander von Welt und Erde ist ein Streit) (HEIDEGGER, 2010, A obra e a verdade, p. 121).

$\mathrm{Na}$ interação lúdica (Widerspiel) do mundo e da terra, "a verdade acontece como disputa originária entre clareira e velamento" (die Wahrheit als der Urstreit von Lichtung und Verbergung geschieht) (HEIDEGGER, 2010, A obra e a verdade, p. 139). Na obra, acontece a verdade como desvelamento do ente em sua totalidade. Deste modo, o que brilha na obra é o belo, não como categoria estética criada pelo autor e recriada pelo leitor, mas como estrutura concreta da própria obra. Nesse horizonte, "a beleza é um modo como a verdade vigora enquanto desvelamento" (Schönheit ist eine Weise, wie Wahrheit als Unverborgenheit west) (HEIDEGGER, 2010, A obra e a verdade, p. 141, itálicos do autor). Questionar a origem da obra de arte implica questionar a atividade criadora do artista, diz-nos Martin Heidegger (HEIDEGGER, 2010, A verdade e a arte, p. 145-201). O criar (Das Schaffen) é, em essência, um pro-duzir (ein Hervorbringen) (HEIDEGGER, 2010, A verdade e a arte, p. 147), não como confecção manual (artesanato) de objetos, mas como pôr-se em obra da verdade como oposição entre iluminação e ocultação, ou seja, como "disputa de Mundo e Terra" (HEIDEGGER, 2010, A verdade e a arte, p. 159).

A criação do artista não é confecção de algo útil, mas produção como um operar do acontecimento da verdade na figura (Gestalt). Noutras palavras, 
a criação artística se revela como o fixar-se da disputa dos contrários na figura (Streit ist die Gestalt) (HEIDEGGER, 2010, A verdade e a arte, p. 163). Por isso, a obra verdadeiramente se apresenta para nós em seu caráter insólito, arrancando-nos, assim, do habitual.

A obra transforma-nos, modifica nossos hábitos, nossas visões, nossos conhecimentos. Somos, inegavelmente, atingidos pela verdade que acontece na obra.

Se a obra não pode ser sem o criador (artista, autor), também não pode ser sem o contemplador (espectador, leitor). A contemplação da obra é a interação do saber e do querer. Portanto, não é a ação de um sujeito, mas "o extático lançar-se do ser humano existente no desvelamento do ser" (das ekstatische Sicheinlassen des existierenden Menschen in die Unverborgenheit des Seins) (HEIDEGGER, 2010, A verdade e a arte, p. 171).

É um ir além de si mesmo, a abertura do Dasein para passar do estar preso no ente à abertura do Ser. Assim, "desvelo da obra é, como saber, a sóbria persistência no extra-ordinário da verdade que acontece na obra" (Bewahrung des Werkes ist als Wissen die nüchterne Inständigkeit im Ungeheuren der im Werk geschehenden Wahrheit) (HEIDEGGER, 2010, A verdade e a arte, p. 173).

Porque o desvelo é um saber, o conhecimento pelo gosto, pelo formal da obra não se legitima. Assim sendo, prossegue Heidegger, "o desvelo da obra não isola os homens em suas vivências, mas os introduz na pertença da verdade que acontece na obra" (Die Bewahrung des Werkes vereinzelt die Menschen nicht auf ihre Erlebnisse, sondern rückt sie ein in die Zugehörigkeit zu der im Werk geschehenden Wahrheit) (HEIDEGGER, 2010, A verdade e a arte, p. 173).

Segundo esta reflexão, a obra não pode ser tomada como um objeto que deve produzir-nos um estado de ânimo, mas sim a partir do seu ser essencial. Desta maneira, a realidade efetiva, processual ou operatividade da obra (Die 
Wirklichkeit des Werkes) (HEIDEGGER, 2010, A verdade e a arte, p. 175) se determina, em seus elementos fundamentais, pela essência do ser-obra. Quer dizer, a essência não metafísica da obra de arte é o diálogo concriativo dos contrários. Afirma Heidegger: "Quando a arte é o originário da obra, então, isto quer dizer que ela, em sua essência, deixa nascer na obra a co-pertença essencial dos que criam e dos que desvelam." (Wenn die Kunst der Ursprung des Werkes ist, dann heißt das, sie läßt das wesenhaft Zusammengehörige am Werk, Schaffende und Bewahrende, in seinem Wesen entspringen) (HEIDEGGER, 2010, A verdade e a arte, p. 181).

A determinação da essência da arte como o pôr-em-obra a verdade (das Wesen der Kunst als das Ins-Werk-Setzen der Wahrheit) (HEIDEGGER, 2010, A verdade e a arte, p. 181) é, afirma-nos Martin Heidegger, propositadamente ambígua. Em um sentido, diz que a arte é a fixação da verdade que se estabelece na figura. Isto acontece na criação como o produzir a desocultação do ente. Mas, pôr em obra significa também: pôr em marcha e fazer acontecer o ser-obra. Isto sucede como desvelo. "Então a arte é o tornar-se e o acontecer da verdade" (Dann ist die Kunst ein Werden und Geschehen der Wahrheit) (HEIDEGGER, 2010, A verdade e a arte, p. 181, itálicos do autor). Noutras palavras, o sentido ou verdade da arte não se esgota no passado, porque se desvela em contínuo intercâmbio ou diálogo com o presente. Não há, de um lado, o criador e, de outro, o contemplador, visto que ambos são um e o mesmo acontecer da verdade do ser na estrutura temporal da existência.

Segundo Heidegger, a verdade da arte não se pode ler no existente e habitual, ou seja, no que se petrificou ou fossilizou. A leitura da verdade não é só do visível (aparente, literal), mas, sobretudo, do invisível (latente, profundo). Como união dialógica ou tensão harmônica dos contrários, toda arte é, em essência, Poesia. Nesse sentido, "A verdade, como clareira e velamento do sendo, acontece no que ela é poietizada. Toda arte é, como o deixar-acontecer a adveniência da verdade do sendo como tal, em essência poiesis" (Wahrheit als die Lichtung und Verbergung des Seienden geschieht, indem sie gedichtet wird. "Alle Kunst" ist als Geschehenlassen der Ankunft der Wahrheit des 
Seienden als eines solchen "im Wesen Dichtung".) (HEIDEGGER, 2010, A verdade e a arte, p. 183, itálicos do autor).

Porém, a Poesia, em sua essência, não é uma imaginação fantasiosa nem expressão do sentimento do artista. A poesia é um dizer projetante do ser.

\begin{abstract}
O narrar inaugural do que se projeta é poiesis: a narração inaugurante do Mundo e da Terra, a narração inaugurante do espaço de jogo de sua disputa e, com isso, do lugar de toda proximidade $e$ distância dos deuses. A poiesis é a fala inaugurante do desvelamento do sendo. A respectiva linguagem é o acontecimento daquele narrar inaugural no qual historicamente surge para um povo seu Mundo e a Terra se guarda como a fechada. O narrar inaugurante que projeta é aquele que, na preparação do narrável inaugurante, traz ao mesmo tempo ao Mundo o não-narrável inaugurante enquanto tal. (Das entwerfende Sagen ist Dichtung: die Sage der Welt und der Erde, die Sage vom Spielraum ihres Streites und damit von der Stätte aller Nähe und Ferne der Götter. Die Dichtung ist die Sage der Unverborgenheit des Seienden. Die jeweilige Sprache ist das Geschehnis jenes Sagens, in dem geschichtlich einem Volk seine Welt aufgeht und die Erde als das Verschlossene aufbewahrt wird. Das entwerfende Sagen ist jenes, das in der Bereitung des Sagbaren zugleiche das Unsagbare als ein solches zur Welt bringt.) (HEIDEGGER, 2010, A verdade e a arte, p. 187-189, itálicos do autor)
\end{abstract}

O diálogo do dizível e do indizível desvela a mútua implicação essencial da linguagem e da poesia. Assim, a essência poética da arte é o acontecer do ser na linguagem. Noutros termos, segundo Heidegger, "a própria linguagem é poiesis em sentido essencial" (Die Sprache selbst ist Dichtung im wesentlichen Sinne) (HEIDEGGER, 2010, A verdade e a arte, p. 189). A linguagem da poesia ou a verdade da arte falam acerca da interação lúdica do mundo e da terra.

Não sendo reprodução da interioridade ou exterioridade do criador e do contemplador, a arte desvela a operatividade ou verdade do ser. A realização da obra implica o questionamento do que nos é familiar ou definido.

A arte é, como o pôr-em-obra da verdade, poiesis. Não somente o criar da obra é poietizante, mas também, do mesmo modo, o desvelar da obra é poietizante, apenas a seu próprio modo; pois uma obra somente é como uma obra real se nós próprios nos livramos de nossos hábitos e nos abrimos ao que se inaugura pela obra, para assim trazer nossa própria essência para permanecer na verdade do sendo. (Die Kunst ist als das Ins-Werk-Setzen der Wahrheit Dichtung. 
Nicht nur das Schaffen des Werkes ist dichterisch, sondern ebenso dichterisch, nur in seiner eigenen Weise, ist auch das Bewahren des Werkes; denn ein Werk ist nur als ein Werk wirklich, wenn wir uns selbst unserer Gewöhnlichkeit entrükken und in das vom Werk Eröffnete einrücken, um so unser Wesen selbst in der Wahrheit des Seienden zum Stehen zu bringen.) (HEIDEGGER, 2010, A verdade e a arte, p. 191, itálicos do autor)

A arte é a poesia da verdade como desvelamento ou acontecimento do ser no tempo. A arte não é o sujeito, mas o jogo de abertura do sentido inesgotável da verdade. Como nos lembra Martin Heidegger: "A essência da arte é a poiesis. Porém, a essência da poiesis é a fundação da verdade" (Das Wesen der Kunst is die Dichtung. Das Wesen der Dichtung aber ist die Stiftung der Wahrheit) (HEIDEGGER, 2010, A verdade e a arte, p. 191, itálicos do autor).

\begin{abstract}
O pôr-em-obra da verdade faz irromper o extra-ordinário e revoga ao mesmo tempo o habitual e o que assim se considera. A verdade que se inaugura na obra jamais é para ser comprovada e deduzida a partir do até então existente. $O$ até então existente é refutado em sua realidade vigente exclusiva através da obra. Por isso, o que a arte funda não pode nunca ser contrabalançado nem compensado através do já existente e do disponível. A fundação é um exceder, uma doação. (Das Ins-Werk-Setzen der Wahrheit stösst das Un-geheure auf und stösst zugleich das Geheure und das, was man dafür hält, um. Die im Werk sich eröffnende Wahrheit ist aus dem Bisheringen nie zu belegen und abzuleiten. Das Bisherige wird in seiner ausschliesslichen Wirklichkeit durch das Werk widerlegt. Was die Kunst stiftet, kann deshalb durch das Vorhandene und Verfügbare nie aufgewogen und wettgemacht werden. Die Stiftung ist ein Überfluss, eine Schenkung.) (HEIDEGGER, 2010, A verdade e a arte, p. 191193)
\end{abstract}

Instaurar, por conseguinte, não é só ofertar e fundar, mas, sobretudo, começar. A arte, em sua essência poética, instaura ou desvela a verdade como o começo de um novo ser, de uma nova história. A verdade da arte é o novo acontecer do ser na história. (HEIDEGGER, 2010, A verdade e a arte, p. 195)

Neste sentido, a arte não é reprodução, mas concriação hermenêutica do diálogo do passado e do presente, ou seja, desvelamento histórico da verdade do ser. Segundo as palavras de Martin Heidegger: "A Arte é história no sentido essencial de que fundamenta história" (Die Kunst ist Geschichte in dem wesentlichen Sinne, da $\beta$ sie Geschichte gründet) (HEIDEGGER, 2010, A verdade e a arte, p. 199). Somente assim pode-se afirmar que 
A arte deixa a verdade eclodir. A arte faz eclodir na obra a verdade do sendo como desvelo que funda. A palavra originário significa fazer eclodir algo, trazer algo ao ser num salto fundador, a partir da proveniência da essência. (Die Kunst läßt die Wahrheit entspringen. Die Kunst erspringt als stiftende Bewahrung die Wahrheit des Seienden im Werk. Etwas erspringen, im stiftenden Sprung aus der Wesensherkunft ins Sein bringen, das meint das Wort Ursprung.) (HEIDEGGER, 2010, A verdade e a arte, p. 199)

Refletir sobre a origem da obra de arte é concriar o impulso ou salto instaurador da verdade como operatividade lúdica do ser em sua historicidade. Noutras palavras,

O originário da obra de arte, isto significa, ao mesmo tempo, dos que criam e dos que desvelam, isto diz do Entre-ser histórico de um povo, é a arte. Isto é assim porque a arte em sua essência é um originário: um modo insigne de como a verdade é sendo, quer dizer, acontece historicamente.(Der Ursprung des Kunstwerkes, d.h. zugleich der Schaffenden und Bewahrenden, das sagt des geschichtlichen Daseins eines Volkes, ist die Kunst. Das ist so, weil die Kunst in ihrem Wesen ein Ursprung ist: eine ausgezeichnete Weise, wie Wahrheit seiend, d.h. geschichtlich wird.) (HEIDEGGER, 2010, A verdade e a arte, p. 199).

As reflexões de Martin Heidegger acerca do enigma da arte (das Rätsel der Kunst) não se apresentam como soluções, mas como elucidações hermenêuticas. Não são considerações estéticas abstratas, desvinculadas da existência, porque não tomam a obra de arte como objeto da percepção sensível de um sujeito centrado em si mesmo. Importa sempre lembrar que a arte é acontecimento da verdade inesgotável do ser, e não do sujeito. Ao artista assim como ao contemplador cabem, pois, a escuta do sentido ou correspondência ao apelo silencioso do ser na linguagem poética da arte. Não bastam as considerações estéticas, pois não atingem a verdade essencial da obra de arte. Portanto, a beleza da obra não pode ser a subjetividade ou impressão sensível do criador (autor) ou do espectador (leitor).

A beleza é a manifestação da verdade como desvelamento da essência poética da arte. Desta maneira, conclui Martin Heidegger:

A verdade é o desvelamento do sendo enquanto sendo. A verdade é a verdade do ser. A beleza não aparece junto desta verdade. Quando a verdade se põe na obra, ela aparece. O aparecer é - como este ser 
da verdade na obra e como obra - a beleza. Assim, o belo pertence ao acontecer-se apropriante da verdade. Não é somente relativo ao gosto e pura e simplesmente como objeto dele. $O$ belo reside na forma, mas apenas pelo fato de que a forma um dia se iluminou a partir do ser como entidade do sendo. (Die Wahrheit ist die Unverborgenheit des Seienden als des Seienden. Die Wahrheit ist die Wahrheit des Seins. Die Schönheit kommt nicht neben dieser Wahrheit vor. Wenn die Wahrheit sich in das Werk setzt, erscheint sie. Das Erscheinen ist - als dieses Sein der Wahrheit im Werk und als Werk - die Schönheit. So gehört das Schöne in das Sichereignen der Wahrheit. Es ist nicht nur relativ auf das Gefallen und lediglich als dessen Gegenstand. Das Schöne beruht indessen in der Form, aber nur deshalb, weil die forma einst aus dem Sein als der Seiendheit des Seienden sich lichtete.) (HEIDEGGER, 2010, A verdade e a arte, p. 207)

A contribuição hermenêutica de Martin Heidegger, sobretudo com $A$ Origem da Obra de Arte (1935/36), será de fundamental importância, como veremos a seguir, para a compreensão da teoria de Hans-Georg Gadamer acerca da ontologia da obra de arte, isto é, da arte como jogo de desvelamento da verdade processual do ser. 


\section{ARTE, JOGO E LINGUAGEM EM HANS-GEORG GADAMER}

"Das Spiel ist die Seinsweise des Kunstwerkes selbst." ("O jogo é o próprio modo de ser da obra de arte.")

Hans-Georg Gadamer

A hermenêutica de Martin Heidegger e a de Hans-Georg Gadamer não trabalham no âmbito da relação lógica ou exclusiva da arte e da verdade, que se tornou normativa a partir da reflexão platônica na República e se radicalizou com a inversão axiológica do platonismo por Nietzsche (Cf. HEIDEGGER, 2007a, Parte I: Vontade de poder como arte, p. 147-195). Ao contrário, propõem-nos o acontecimento originário da verdade como a operatividade lúdica da arte (Cf. GADAMER, 1997, Primeira Parte: A liberação da questão da verdade desde a experiência da arte, p. 37-269). O jogo da arte é o acontecimento desvelante autovelante da verdade do ser (Alétheia). Não é o sujeito (autor/leitor, artista/espectador) quem joga primordialmente, mas 0 próprio movimento de desocultação do ser. O homem é tão-somente 0 aprendiz ou jogador no sério jogo da verdade do ser. Portanto, não há, de um lado, a arte e, de outro, a verdade; a ficção, de um lado e, de outro, a realidade, mas, originariamente, a indistinção ou interação lúdica de ambas. A arte da ficção põe em jogo a verdade originária da realidade.

Neste capítulo, apresentaremos, pois, a mútua implicação da concepção heideggeriana acerca da essência poética da arte e da contribuição gadameriana da arte como jogo de desvelamento da verdade.

\subsection{A arte como jogo da verdade}

Uma hermenêutica filosófica da compreensão que desvele a experiência originária da verdade da arte, da história e da linguagem, eis o propósito da obra magna de Hans-Georg Gadamer, denominada Verdade e Método (Wahrheit und Methode), primeiramente publicada em 1960 (GADAMER, 
1997). Contrária, portanto, à objetividade do método científico que legitima a subjetividade do investigador frente ao conhecimento do real, a hermenêutica gadameriana fala sobre a compreensão humana do mundo da vida. Anterior à verdade da ciência, encontra-se a verdade da experiência como indistinção do ser e do saber. Não importa apenas explicar corretamente, mas compreender profundamente o sentido da experiência vital no horizonte finito da temporalidade. Segundo Gadamer, a ciência constrói a distinção entre o sujeito e o objeto, o homem e o mundo como forma de legitimar o domínio sobre a verdade. Deste modo, tenta obscurecer o efeito da arte, da história e da linguagem sobre a experiência humana. Mas a própria ciência não é capaz de se autoquestionar e verificar o seu caráter derivado com respeito à verdade originária da compreensão. Necessário, portanto, é resgatar o diálogo concriativo do homem e do mundo, do intérprete e do texto, do passado e do presente como meio de superação da consciência científica para que a verdade do ser não se reduza ao totalitarismo do ente.

O mundo da vida é considerado, então, como texto em contínua interpretação, o ser como linguagem e a verdade como acontecimento. Não há nada previamente estabelecido que não se ponha em questão. Não se privilegia, portanto, o sujeito, mas tão-somente o ser que se representa na interpretação do mundo.

A partir da reflexão sobre a verdade da arte, Gadamer repensa o conceito de história e, por fim, o conceito de linguagem como meio da experiência humana do mundo. Veremos, pois, como a proposição gadameriana da arte como jogo é, ao mesmo tempo, a compreensão ou desvelamento da verdade histórica do ser no horizonte da linguagem.

Hans-Georg Gadamer, seguindo os passos da investigação heideggeriana acerca da origem da obra de arte, propõe o conceito de jogo como instância hermenêutica que supera a determinação metafísica da arte como imitação externa (objetividade) ou interna (subjetividade) do real.

Nesse sentido, o jogo não é a exposição da subjetividade do intérprete 
na objetividade do texto. É justamente contra essa interpretação subjetiva do jogo que se opõe Hans-Georg Gadamer ao falar sobre "a ontologia da obra de arte e seu significado hermenêutico" (Die Ontologie des Kunstwerkes und ihre hermeneutische Bedeutung) (GADAMER, 1997, p. 174-269). Não é a subjetividade do intérprete que comanda a interpretação da obra de arte, mas a própria atividade lúdica. A obra de arte não é um objeto que se submete ao império do sujeito:

\begin{abstract}
A obra de arte tem, antes, o seu verdadeiro ser em se tornar uma experiência que irá transformar aquele que a experimenta. $\mathrm{O}$ "sujeito" da experiência da arte, o que fica e persevera, não é a subjetividade de quem a experimenta, mas a própria obra de arte. (Das Kunstwerk hat vielmehr sein eigentliches Sein darin, da $\beta$ es zur Erfahrung wird, die den Erfahrenden verwandelt. Das "Subjekt" der Erfahrung der Kunst, das was bleibt und beharrt, ist nicht die Subjektivität dessen, der sie erfährt, sondern das Kunstwerk selbst) (GADAMER, 1997, p. 175)
\end{abstract}

O sujeito do jogo artístico não são os jogadores, mas o próprio jogar. Esse movimento lúdico não tem objetivo final, porém se renova em constante repetição. Carece de substrato, pois não se pauta pelo sujeito. Noutras palavras, o jogo é a pura realização do movimento. É um auto-representar-se. Nesse sentido, afirma Gadamer, o modo de ser próprio da obra de arte é o eterno fazer-se a si mesma, o eterno movimento lúdico de vaivém ou de desvelamento do ser.

A interação do jogador e do jogo não é a de um sujeito frente a um objeto. Pelo contrário, o jogo é quem desafia o jogador e exige cada vez mais a sua participação. $O$ jogador tem que se abrir ao diálogo lúdico, ou seja, à interpelação do sentido, caso contrário não se realiza. Somente na correspondência ao apelo do jogo, o jogador pode ser mais originariamente. Saindo de si mesmo, o jogador (Dasein) põe em questão o próprio ser. Por isso, "o próprio jogo é um risco para o jogador" (ist das Spiel selbst ein Risiko für den Spieler) (GADAMER, 1997, p. 180), ou seja, só se pode jogar com possibilidades sérias. $O$ apelo irresistível que o jogo exerce sobre o jogador consiste no risco de se realizar ou não as suas expectativas ou projetos. $O$ jogo é sério, porque põe em risco o horizonte vital do jogador. Portanto, o jogo não é senão de vida e morte, esperança e desesperança, segurança e 
insegurança.

Gadamer chega a afirmar o caráter efetivo ou operativo do jogo com respeito ao jogador: "Todo jogar é um ser-jogado" (Alles Spielen ist ein Gespieltwerden) (GADAMER, 1997, p. 181). E, em seguida, adverte: "O atrativo do jogo, a fascinação que exerce, reside justamente no fato de que o jogo se assenhora do jogador" (Der Reiz des Spieles, die Faszination, die es ausübt, besteht eben darin, da $\beta$ das Spiel über den Spielenden Herr wird) (Idem). O homem joga correspondendo ao movimento lúdico do ser.

Pode-se afirmar que, assim como a compreensão é o modo de ser próprio do Dasein (Heidegger), o jogo é o modo de ser próprio da obra de arte (Gadamer). Em ambos, a verdade não é um domínio do ente (homem, intérprete, jogador), mas o jogo de velamento e desvelamento do próprio ser.

O jogo não precisa ter vários jogadores para ser realizado. Mesmo quando está jogando sozinho, a experiência mostra que o verdadeiro sujeito do jogo não é o jogador, mas o próprio jogo. É este que o mantém enfeitiçado ou encantado, que o enreda e o mantém no jogo. Logo, o modo de ser do jogo é a auto-representação (Selbstdarstellung).

\begin{abstract}
A auto-representação do jogo faz, ao mesmo tempo, que o jogador alcance sua própria auto-representação, enquanto ele joga algo, isto é, representa. Somente porque jogar já é sempre um representar, é que o jogo humano pode encontrar na própria representação a tarefa do jogo. (Die Selbstdarstellung des Spieles bewirkt so, da $\beta$ der Spielende gleichsam zu seiner eigenen Selbstdarstellung gelangt, indem er etwas spielt, d.h. darstellt. Nur weil Spielen immer schon ein Darstellen ist, kann das menschlische Spiel im Darstellen selbst die Aufgabe des Spieles finden) (GADAMER, 1997, p. 183-184)
\end{abstract}

O caráter lúdico ou o ser da arte, diz-nos Gadamer, consiste na remissão ou destinação do sentido própria de toda representação. Quer dizer: "Todo representar, de acordo com a sua possibilidade, é um representar para alguém" (Alles Darstellen ist nun seiner Möglichkeit nach ein Darstellen für jemanden) (GADAMER, 1997, p. 184). O jogo é uma exibição ou abertura de sentido ao jogador ou espectador, bem o prova a representação dramática. $A$ representação lúdica remete sempre a quem vai jogar junto, ou seja, a quem 
vai participar e partilhar de uma significação transformadora. $O$ jogo realiza o seu efeito sobre o espectador, por isso é sempre uma experiência de diálogo. Deste modo, "o jogador experimenta o jogo como uma realidade que o sobrepuja" (Der Spielende erfährt das Spiel als eine ihn übertreffende Wirklichkeit) (GADAMER, 1997, p. 185). Portanto, a arte, como compreensão lúdica da verdade, torna possível que o jogador (leitor, intérprete, espectador) experimente a excessividade do ser e seja transformado por ela. A arte remete à existência do "outro". Afirma Gadamer: "A representação da arte, de acordo com a sua natureza, é de tal maneira que é para alguém, mesmo quando não há ninguém que sequer a ouça ou assista." (Die Darstellung der Kunst ist ihrem Wesen nach so, da $\beta$ sie für jemanden ist, auch wenn niemand da ist, der nur zuhört oder zuschaut) (GADAMER, 1997, p. 187).

Gadamer elabora a expressão "transformação em configuração" (Verwandlung ins Gebilde) para denominar o processo pelo qual o jogo humano atinge a sua verdadeira perfeição, a de ser arte. Gebilde, configuração ou conformação, compreende, simultaneamente, o caráter de obra (ergon) e de invenção (energeia). Noutras palavras, a operatividade ou configuração lúdica da arte possui autonomia com respeito ao representador, espectador ou artista da obra. O jogo remete a ou dialoga com o autor (artista) e o leitor (espectador, jogador, intérprete), mas não depende deles. O ser da arte é a transformação, e nunca a confirmação da subjetividade do autor ou do leitor. Verwandlung, transformação, não quer dizer alteração, mas que algo se converte de repente e completamente em outra coisa, ou seja, em seu verdadeiro ser, perante o qual seu ser anterior não é nada. Verwandlung ins Gebilde, afirma Gadamer, quer dizer que "aquilo que era antes, não é mais" (was vorher ist, nicht mehr ist) e que "o que agora é, que se representa no jogo (espetáculo) da arte, é a verdade duradoura" (was nun ist, was sich im Spiel der Kunst darstellt, das bleibende Wahre ist) (GADAMER, 1997, p. 188). O jogo não pode ser compreendido a partir da subjetividade do jogador, caso contrário seria apenas um disfarce. Não basta parecer, mas, sobretudo, ser outro. O movimento lúdico modifica quem o experimenta de tal modo que é impossível ao jogador continuar enganando a si mesmo ou aos outros. 
O jogo, ele mesmo, é de tal maneira uma transformação que para ninguém continua a existir a identidade daquele que joga (representa). [...] Os jogadores (atores) (ou o dramaturgo) não mais existem, mas tão-somente o que é jogado (representado) por eles. (Das Spiel selbst ist vielmehr derart Verwandlung, da $\beta$ für niemanden die Identität dessen, der da spielt, fortbesteht. [...] Die Spieler (oder Dichter) sind nicht mehr, sondern nur das von ihnen Gespielte) (GADAMER, 1997, p. 189)

O jogo configura o seu próprio mundo, não necessitando, portanto, de uma referência externa. Quer dizer, não é uma cópia da realidade preestabelecida em que se move o autor ou o leitor, mas uma autorepresentação do sentido ou novo des-velamento do ser. Verwandlung ins Gebilde é o processo de configuração da obra de arte: "A transformação é transformação no verdadeiro" (Die Verwandlung ist Verwandlung ins Wahre) (GADAMER, 1997, p. 190). "Na representação do jogo (espetáculo) resulta o que é" (In der Darstellung des Spieles kommt heraus, was ist) (Idem), ou seja, nela desoculta-se o ser que sempre se oculta. No jogo, o mistério ou velamento do ser de repente se desvela. Eis o verdadeiro sentido da autorepresentação: o ser configura-se, ao mesmo tempo, iluminando-se e encobrindo-se.

Segundo Gadamer, a "realidade" (Wirklichkeit) encontra-se sempre em um horizonte de futuro (Zukunftshorizont) de possibilidades desejadas e temidas, e jamais anuladas. A indefinição do futuro (Die Unentschiedenheit der Zukunft) é que abre um excesso de expectativas atrás das quais permanece a realidade. Quem verdadeiramente existe tem as suas expectativas ou seu horizonte de compreensão modificados ou ampliados pelo jogo do mundo. A realidade do jogador é, portanto, um processo de realização. Nesse sentido, jogar (existir, ler, interpretar) é um constante experimentar a alteridade, realidade ou verdade do ser como jogo.

A realidade processual do jogo (die Wirklichkeit des Spieles) configurase como o próprio jogo da arte (das Spiel der Kunst). Esta, por sua vez, não define, mas desvela a realidade em seu jogo de ocultação e desocultação simultâneas. Assim, diz-nos Gadamer, "o ser de todo jogo é sempre resgate, pura realização, Energeia, que traz seu telos em si mesmo" (Das Sein alles 
Spieles ist stets Einlösung, reine Erfüllung, Energeia, die ihr "Telos" in sich selbst hat) (GADAMER, 1997, p. 190, itálicos do autor). E, por isso, "O mundo da obra de arte [...] é, de fato, um mundo totalmente transformado" (Die Welt des Kunstwerkes [...] ist in der Tat eine ganz und gar verwandelte Welt) (Idem). Ele não legitima a realidade dada ou preestabelecida pelas normas sociais de conduta. Pelo contrário, ele transforma ou supera essa realidade ao questionar pela verdade originária do ser.

A arte não é imitação fotográfica, mas suscitação ou des-velamento da verdade do ser. Segundo Gadamer, o conceito de imitação (Mimesis), elaborado pela teoria antiga da arte, pode caracterizar o jogo da arte, desde que o seu sentido cognitivo seja resgatado. Durante muito tempo, a concepção aristotélica da arte foi entendida como cópia da realidade, não possuindo, portanto, verdade em si mesma. A mimesis tornou-se, na estética clássica, reprodução (imitatio) de um modelo externo, e, na estética romântica, reprodução de um modelo interno ao poeta. Em ambos os casos, o sentido originário da poética aristotélica perdeu-se. Com o propósito de superar a dicotomia interno/externo ou sujeito/objeto é que Gadamer propõe o conceito de jogo como modo de ser próprio da obra de arte. A arte é mimesis, não como imitação mecânica, mas como jogo de des-ocultação ou configuração transformadora do ser de todos os entes. O que a arte imita ou representa não é a subjetividade do autor, não é uma essência exterior (metafísica da idealidade) nem interior (metafísica da subjetividade). Pelo contrário, a arte representa o próprio ser que se vela enquanto se desvela no horizonte finito do tempo. Diz-nos Gadamer: "Aí, encontra-se o que é representado - eis a relação mímica originária" (Das Dargestellte ist da - das ist das mimische Urverhältnis) (GADAMER, 1997, p. 181). Quem joga imita ou representa não a própria identidade ou subjetividade, mas sim a alteridade constitutiva do ser. Logo, a arte é a representação do novo ser, do "outro", ou seja, a transformação no verdadeiro. Não importa quem representa (ente), mas o que se representa (ser).

O sentido cognitivo da mimesis é o reconhecimento (der Erkenntnissinn von Mimesis ist Wiedererkennung). Porém, prossegue Gadamer, "a alegria do 
reconhecimento reside, antes, no fato de identificarmos mais do que somente o que é conhecido" (Die Freude des Wiedererkennens ist vielmehr die, da $\beta$ mehr erkannt wird als nur das Bekannte) (GADAMER, 1997, p. 192, itálicos do autor). A arte desvela a verdade excessiva do ser e, por isso, é sempre um apelo ao homem para que seja mais originariamente. Logo, o conhecimento é uma contínua renovação do ser, e nunca uma petrificação. $O$ homem reconhece-se "outro", ou seja, mais verdadeiro, quando aprende a jogar ou se deixa transformar pelo sério jogo do mundo da obra de arte. Conhecer a verdade da arte não é deter-se no representado, mas sim ser conduzido pelo ser da própria representação. Deste modo, Gadamer esclarece que a imitação e a representação não se resumem à cópia, porque são o conhecimento da essência originária da arte. No entanto, a função cognitiva da mimesis perdeuse com a subjetivação estética realizada por Kant.

O modo de ser ou a essência verdadeira do jogo e da obra de arte é a auto-representação. Ela apela ao espectador e transforma-o em parte ativa da representação, independente da distância temporal em que se situe. Consequentemente, o ser da arte não pode determinar-se como objeto de uma consciência estética. Noutras palavras, a verdade lúdica antecede o domínio da subjetividade e da objetividade, a instância subjetiva do gosto como critério de avaliação da arte.

O jogo é configuração (Das Spiel ist Gebilde), mas a configuração é também jogo (Das Gebilde ist aber auch Spiel). Gadamer enuncia, assim, a mútua implicação ou correspondência recíproca entre a formação e a transformação da própria obra de arte como oposição à consciência estética. $\mathrm{Na}$ experiência da arte, o que verdadeiramente acontece é a "indiferenciação estética" (die ästhetische Nichtunterscheidung) (GADAMER, 1997, p. 196, itálicos do autor). Deste modo, o jogo da obra de arte não é a distinção da invenção e da execução, da forma e do conteúdo, mas a interação contínua de ambos. Neste ponto, Gadamer concorda com a estética da formatività de Luigi Pareyson (Cf. PAREYSON, 1993; Idem, 1984), segundo a qual a obra de arte somente se configura ou alcança o seu verdadeiro ser na mediação ou processo dialético da concepção e da execução e não na subjetividade do 
autor ou do leitor, do artista ou do espectador. O jogo da arte é a configuração poética do seu sentido, a sua auto-representação. É, portanto, a autorepresentação do sentido "o que é imitado na imitação, formulado pelo poeta, representado pelo ator, reconhecido pelo espectador" (das in der Nachahmung Nachgeahmte, vom Dichter Gestaltete, vom Spieler Dargestellte, vom Zuschauer Erkannte) (GADAMER, 1997, p. 196), e não simplesmente a subjetividade de cada um. O jogo da arte é a unidade dual da verdade, ou seja, a indistinção dos contrários: ficção e realidade, literatura e existência, vida e morte, ser e não-ser. A configuração (Gebilde, Formatività) do sentido é inerente à natureza da obra de arte, e não à consciência subjetiva ou objetiva do intérprete. Essa natureza configura, portanto, o seu próprio mundo independente da recepção, que apenas sofre o efeito e, consequentemente, corresponde ao jogo da arte.

Segundo Gadamer, a interpretação da obra de arte efetiva-se por uma "intermediação total" (Totale Vermittlung) (GADAMER, 1997, p. 200), quer dizer, o mediador (intérprete) enquanto mediador se anula ou suprime a si mesmo. Esta instância hermenêutica faz a obra representar e desvelar o seu próprio sentido. A obra interpretada torna-se, então, a obra interpretante. $\mathrm{O}$ sujeito do jogo é o próprio movimento lúdico, e não o jogador. Assim, o intérprete verdadeiro é aquele que se desvela ao participar da obra, ou seja, que se deixa fascinar pelo jogo simbólico e festivo da arte. (Cf. GADAMER, 1985)

\subsection{A compreensão lúdica da linguagem}

Hans-Georg Gadamer, seguindo os passos da reflexão heideggeriana acerca da compreensão ontológica, elabora o conceito de jogo como instância hermenêutica de elucidação do modo de ser próprio da obra de arte. A relação do homem (Dasein) e do mundo (Ser) torna-se, então, a relação dialógica do intérprete e do texto. Em ambos os casos, o homem (intérprete ou jogador) não é o sujeito da compreensão do mundo (texto), mas sim o próprio jogo em seu movimento de velamento e desvelamento. No jogo da compreensão do 
mundo ou do texto, quem comanda é a própria verdade lúdica do ser. Assim, pode-se afirmar que o homem (intérprete) sofre o apelo do ser (jogo) ao exercer a leitura do mundo (texto). O Dasein não é o sujeito do ser, mas, ao contrário, o ser enquanto desvelamento autovelante é o sujeito do Dasein. $O$ ser, assim como o texto, tem uma estrutura apelativa com relação ao homem. Deste modo, somente correspondendo à verdade do ser (texto) pode o homem existir (interpretar) concretamente no horizonte do tempo. Verdade do Ser e Verdade da Arte mutuamente se implicam na hermenêutica heideggeriana e na gadameriana.

A verdade do ser, a existência do Dasein, o acontecimento da linguagem constituem, portanto, para Gadamer, a própria experiência lúdica da obra de arte, ou seja, o movimento lúdico que medeia entre o texto e o intérprete. O Dasein (intérprete) é jogado pelo ser-no-mundo (texto). O homem é atraído pelo mundo do texto e passa a participar do seu espaço de representação. O homem (intérprete, jogador, autor, leitor, espectador) é jogado pelo jogo do mundo (texto, campo, obra, teatro) e, nesse sentido, é sempre uma estrutura implícita ao jogo. Logo, ler ou compreender o mundo (texto) é desde já ser lido ou compreendido por ele. Não é a subjetividade que comanda a compreensão da verdade do ser, afirma Heidegger. Também não é a subjetividade que comanda a compreensão da verdade da arte, afirma Gadamer. Com efeito, o jogo da compreensão e o jogo da arte são um e o mesmo no processo de desvelamento da verdade a que corresponde o homem (Dasein, intérprete, jogador), não enquanto sujeito, mas enquanto abertura ou projeto do ser.

A experiência hermenêutica da compreensão, segundo Gadamer, é a interação lúdica do homem e do mundo, do ser e do saber, do sujeito e do objeto, do texto e do intérprete no horizonte da linguagem (GADAMER, 1997, Terceira Parte: A virada ontológica da hermenêutica no fio condutor da linguagem, cap. 1, p. 559-589 e cap. 3, p. 639-709). Assim, a existência é um diálogo incessante acerca da verdade. Porém, a verdade não está previamente estabelecida, não é a concordância do sujeito ao objeto nem a subjetividade imperial. A verdade é o desvelamento (Alétheia) do ser na 
linguagem. O homem não domina a verdade do ser, mas, misteriosamente, é dominado por ela.

Quando compreendemos um texto, estabelecemos um diálogo com a tradição. O texto nos fala em sua verdade ou sentido e, assim, correspondendo, participamos de um sentido comunitário e nos deixamos ser modificados por ele. Enriquecemos nosso horizonte de compreensão sofrendo a experiência do ser na linguagem e da linguagem do ser. O mundo (texto) da vida apresenta-se a nós como infinitamente interpretável. A leitura do mundo torna-se, simultaneamente, a escritura do nosso ser no horizonte finito do tempo. Toda leitura compreensiva se dá numa estrutura circular ontológica, conforme nos mostrou Heidegger. Em qualquer parte que se encontre, a compreensão é guiada pela totalidade de sentido que o texto representa. Somente na mediação da parte e do todo configura-se a representação do sentido, ou seja, compreender é ser jogado pelo movimento lúdico de desvelamento da verdade. A representação é o modo de ser do próprio jogo da compreensão. Por isso, colocamos sempre em risco o nosso ser quando verdadeiramente interpretamos. Compreender é, pois, a encenação dramática da própria existência no horizonte finito do tempo. O homem sofre a experiência do ser, mais do que age. Noutros termos, ler é sofrer o impacto do ser na fusão de horizontes do passado e do presente.

O fenômeno da interpretação não é senão o acontecimento ou desvelamento da verdade do ser na dimensão originária da linguagem. Gadamer, assim, enuncia: "O ser que pode ser compreendido é linguagem" (Sein, das verstanden werden kann, ist Sprache) (GADAMER, 1997, p. 687, itálicos do autor). Não só a arte e a história, mas também a existência humana é representação do sentido na linguagem.

A linguagem não pertence ao homem, mas à própria realidade processual da existência no mundo. No jogo linguístico da existência, experimentamos a união dos contrários, do passado e do presente, do ser e do saber, do homem e do mundo, do texto e do intérprete, da vida e da morte. A experiência humana é a da finitude do ser como possibilidade da 
compreensão. Deste modo, Gadamer afirma que a própria realidade já de si é o acontecer da linguagem. O real nunca é estático, mas um tecido de relações ou um contínuo diálogo do homem e do mundo.

Não se pode falar de um jogo com a linguagem, mas "do jogo da própria linguagem, que nos interpela, propõe e se recolhe, que pergunta e que se consuma a si mesmo na resposta" (von dem Spiel der Sprache selbst, die uns anspricht, vorschlägt und zurückzieht, fragt und in der Antwort sich selbst erfüllt) (GADAMER, 1997, p. 708, itálico nosso). O jogo da linguagem é a própria verdade da compreensão. Nesse jogo, afirma Gadamer, o jogador não se comporta subjetivamente como se estivesse frente a um objeto, pois "é, antes, o próprio jogo o que joga, na medida em que inclui em si os jogadores e se converte desse modo no verdadeiro subjectum do movimento lúdico" (das Spiel es ist, das spielt, indem es die Spieler in sich einbezieht und so selber das eigentliche subjectum der Spielbewegung wird) (Idem, itálico do autor). Por conseguinte, a compreensão ontológica revela que o homem (Dasein) é jogado pelo jogo da linguagem enquanto verdade desvelante auto-velante do próprio ser. O jogo originário do Ser é o símbolo do mundo no qual o homem está inserido e ao qual corresponde existindo.

O jogo circular da compreensão da parte e do todo ou do homem e do mundo é o próprio acontecimento da linguagem do ser (Cf. GADAMER, 2002, Sobre o círculo da compreensão (1959), p. 72-81; Idem, Linguagem e compreensão (1970), p. 216-233). Na e através da linguagem o homem compreende o ser e, ao mesmo tempo, autocompreende-se (Cf. GADAMER, 2002, Sobre a problemática da autocompreensão (1961), p. 145-159; Idem, Homem e linguagem (1966), p. 173-182). Sem dúvida, a existência é o jogo originário de iluminação e encobrimento do ser, e nunca a confirmação da subjetividade do ente. $O$ homem não é senão enquanto devém. Noutras palavras, a existência humana não é a identidade do sujeito, mas a possibilidade lúdica do ser.

Portanto, não nos resta senão reafirmar que a grande contribuição da hermenêutica de Martin Heidegger e Hans-Georg Gadamer foi mostrar que 
somente o diálogo lúdico ou concriativo da compreensão da verdade e da linguagem do ser caracteriza a existência concreta do homem. Deste modo, a arte, a história e a linguagem apresentam-se como o sério jogo de desvelamento da verdade ao qual correspondemos como jogadores ou intérpretes.

Com base nessas considerações, mostraremos a seguir como a verdade originária e lúdica da arte, ou seja, a mundividência dionisíaca da tragédia grega nos possibilitará a compreensão de uma escrita da morte na narrativa dramática O Risco do Bordado, de Autran Dourado. 


\title{
3. A ARTE DRAMÁTICA, A VISÃO DIONISÍACA E A ESCRITA DA MORTE
}

\author{
"Mas Hades e Dionísio é o mesmo, para quem \\ deliram e festejam."
}

Heráclito, fr. 15.

\begin{abstract}
"Dionisos: sensibilidade e pavor. A transitoriedade poderia ser interpretada como gozo da força engendradora e destruidora, como criação constante."
\end{abstract}

Friedrich Nietzsche. A vontade de poder, fr. 1049.

\subsection{A tragédia grega e o drama de paixão}

A questão da tragédia grega é, sobretudo, a experiência dramática do destino, da finitude, da contradição ou da temporalidade que envolve o homem e o mundo. Não postulando um ser a priori no passado ou um ser a posteriori no futuro, a tragédia grega trabalha com a estrutura unitária do tempo: futuropresente-passado. A posição frontal do futuro se justifica porque o ser somente existe enquanto impulso constante do desvelamento. $O$ futuro concreto é 0 impulso do ser. Um desvelamento definitivo do ser só pode produzir uma doutrina arqueológica ou escatológica, como se pode verificar na filosofia platônica e no cristianismo. A tragédia se revolta contra estas interpretações lógicas do mundo. Não aceita pensar a vida para além dos limites da morte nem a morte para além dos limites da vida. A tragédia representa a morte inserida na estrutura vital do homem e do mundo. Portanto, as experiências concretas da finitude humana são as lições trágicas da vida.

O destino, o futuro que se concretiza, não é senão o impulso da vida para além do sabido e do definido. Assim, personagem trágico é aquele que cuida do seu porvir, e o porvir não é senão a morte enquanto possibilidade de existência. Morte que é abertura de um novo sentido, e não clausura. E não é por outro motivo que Dioniso está na tragédia mesmo quando não aparece. Porque dionisíaco, transgressivo, excessivo é o próprio ser humano enquanto assume a finitude radical da existência. Ser finito porque pode compreender o que se oculta enquanto se desoculta no caminho da vida. No texto trágico da 
existência, o caminho da vida e a estrada da morte mutuamente se implicam. A morte não está no fim, mas no meio da vida. E o meio está onde a experiência se realiza. O homem não percorre um caminho, pois o seu destino é uma aprendizagem constante. O caminho sempre passa por ele. O homem atravessa as coisas muito antes de defini-las. Ele conhece as coisas porque nasce com (con-naître) elas. Conhece por sofrê-las (pathos). O homem sofre 0 impacto de suas existências. Como nos ensina o dramaturgo Ésquilo (1991, v. 212, p. 25), em Agamêmnon, o homem aprende pelo sofrer (pathei mathos); sente, atravessando as coisas (catarse).

A tragédia grega não é a filosofia abstrata da vida, mas a experiência concreta da finitude nos mais simples incidentes do cotidiano. O personagem trágico sofre uma transmutação no verdadeiro. Sofre uma revolução que destrói seu ser inautêntico e propõe um novo ser. Há o despertar de um novo sentido. E esse sentido trágico não se guia simplesmente pelos homens nem é guiado pelos deuses na tragédia grega, pois se manifesta, primordialmente, como o jogo dionisíaco do mundo que possibilita a existência de ambos. Nas palavras do eminente estudioso Emmanuel Carneiro Leão, "Trágico é o jogo de Dionísio na identidade universal das diferenças. A tragédia não é uma condição simplesmente humana. É o ser da própria realidade." (LEÃO, 1991, p. 11).

Assim, a situação hermenêutica apropriada para a interpretação do texto trágico como drama de paixão (estático), e não simplesmente como drama de ação (cinético), é aquela que abandona a oposição antagônica do ser e do nãoser, do sujeito e do objeto, do saber e do ser preconizado pela paideia filosófica da metafísica ocidental instaurada por Platão ( $A$ República) e Aristóteles (Poética), e busca a compreensão do sentido poematizado como oposição complementar pela paideia poética do saber pelo sofrer (pathei mathos), proposta por Ésquilo, como bem realizaram Friedrich Nietzsche (1992) e Friedrich Hölderlin (1994).

A tragédia grega é a interpretação, a exegese das ações, e não simplesmente a representação da trama das ações consecutivas. Não constitui objeto de representação propriamente cênica o que aconteceu nem por que aconteceu. As ações que dramaticamente se representam são sempre submetidas ao questionamento 
hermenêutico e suplantadas pelas reações mentais e emocionais dos personagens. No drama ático, o que se representa é a demanda do sentido do que acontece hic et nunc no palco. Numa formulação paradoxal, mas rigorosamente verdadeira, a tragédia grega é um drama sem ação, um drama estático. [...] A tragédia grega não é uma trama de ações, mas um drama de paixões. (SOUZA, 2010, Atualidade da tragédia grega, p. 58-59 e 61)

A conquista de um novo ponto de vista para descobrir os mistérios da vida, desvirtuados pela concepção lógica da existência, é o princípio dinâmico da poesia e do pensamento dos grandes dramaturgos gregos: Ésquilo, Sófocles e Eurípides. Nas experiências concretas da vida ou nas humildes coisas do cotidiano, a relação lógica $A$ é $A$ é desmentida pela relação dialógica $A$ é não- $A$ (ou $A$ é $B$ ). Ser é não ser paralisado pela objetividade ou pela subjetividade imperial. Contrariando a lógica, a tragédia grega mostra que "... poeticamente o homem habita esta terra..." (HÖLDERLIN, "No azul sereno...", apud HEIDEGGER, 2002b, p. 165-181).

A tragédia fala da vitalidade, da integridade e da liberdade do ser. E o personagem só é trágico quando não está preso a regras. Assim decidido, passa a criar as suas próprias regras e o seu próprio ser. Ele sabe, por experiência, que onde há lógica há escravidão. A lógica é insuficiente para tratar das questões da vida. Impondo limites e excluindo possibilidades, a lógica é a prisão da liberdade. Na arte trágica, os personagens não se limitam ao comedimento (sophrosyne), pois experimentam o descomedimento e a excessividade (hybris) da verdade do ser (alétheia). À identidade do ente se contrapõe a alteridade do ser. E a verdade se interpõe como desvelamento do sentido da vida que emana da experiência de finitude. Portanto, a tragédia representa a liberdade da vida numa afirmação absoluta. Afirmar a vida é transcender as limitações e as antíteses lógicas que impelem o seu livre fluir.

No texto trágico, importa a experiência. A experiência de ver as coisas como são, ou seja, em sua fluência e não paralisadas pelos conceitos. É justamente a ruptura dos conceitos abstratos que modifica a visão do homem. A visão trágica é a visão das profundidades. O homem trágico aprende a viver nas profundidades da vida. Conforme nos diz Friedrich Nietzsche, em sua obra Assim falou Zaratustra, ele vê os abismos da vida e sofre os seus impactos: "O 
próprio ver não é - ver abismos?" (NIETZSCHE, 2011b, p. 149). Vê a morte na vida e vive a sua própria morte. Para o personagem trágico, viver é compreender, ou seja, saber pelo sofrer, a finitude, o sentido ou a verdade do ser no horizonte do tempo.

A verdade trágica não está no interior nem no exterior do personagem, mas na mediação constante do sentido que advém das experiências sofridas no contexto da vida. Na verdade trágica, não existe dentro ou fora. Há, sobretudo, a experiência da insubstancialidade da vida. O homem trágico pisa em abismos e não sucumbe. Ele retoma o fluxo contínuo da vida, pois vê que o sentido da existência está na alteridade, e não na identidade. Um homem idêntico a si mesmo não reconhece a existência dos outros. E não reconhece, sobretudo, porque não se conhece.

A maturidade trágica do personagem é a integração da morte na vida. É a reconciliação dos opostos luz e trevas, inteligível e sensível, bem e mal como partes integrantes da realidade. O equilíbrio dinâmico de contrários é a sabedoria do homem trágico. A experiência humana é sempre a experiência de finitude. Assim, o drama do homem, do mundo e de Dioniso se representa como unidade passional dos contrários na tragédia grega.

\subsection{A visão dionisíaca do mundo e a escrita da morte}

Dioniso é, ao mesmo tempo, filho de um imortal (Zeus) e de uma mortal (Sêmele). Pertence, por natureza, a dois reinos. Isso implica caracterizá-lo, já em seu nascimento, como o deus da contradição. O seu aspecto contraditório formou-se e intensificou-se na passagem da civilização pré-helênica para a helênica, quando o mito e o culto de Dioniso se transformaram na própria representação do drama ático. Deste modo, afirma o eminente pensador Mario Untersteiner (1955), no seu belíssimo livro Le Origini della Tragedia e del Tragico, que o fundamental e originário aspecto do deus é "la contradizione implicita nella compresenza, in un solo essere, di vita e di morte" (UNTERSTEINER, 1955, p. 90). 
O encontro de duas civilizações - a pré-helênica e a helênica - se realiza dramaticamente na tragédia grega. Conforme Eudoro de Sousa (1973), em sua obra Dioniso em Creta, "Desumano é o mito pré-helênico, tanto quanto é humana a civilidade e a politicidade clássicas" (SOUSA, 1973, Mito préhelênico e mitologia grega, p. 146). A visão desumana e poética do mundo precede a divisão humana e lógica do mundo em duas ordens antagônicas: a do sensível e a do inteligível. O reino dos Ctônicos e o reino dos Olímpicos travam um combate inesgotável que se representa na figura de Dioniso, o Estrangeiro. A representação dramática nas peças de Ésquilo, Sófocles e Eurípides era o reconhecimento de que "in questo dio stava la rivelazione di un eterno aspetto del mondo: il contrasto irriducibile degli opposti" (UNTERSTEINER, 1955, p. 91).

Walter F. Otto realiza, no seu livro Dioniso, Mito y Culto (2006), cujo original alemão foi publicado em 1933, um estudo hermenêutico sobre a importância originária, e não simplesmente evolutiva, da mundividência dionisíaca não só para a Antiguidade como também para a modernidade. Os grandes poetas e pensadores de todos os tempos como, por exemplo, Homero, Hesíodo, Ésquilo, Sófocles, Eurípides, Heráclito, Goethe, Hölderlin e Nietzsche produziram suas obras a partir de um diálogo concriativo com a natureza ambígua e a visão mitopoética de Dioniso acerca da compreensão do mundo e do homem. Uma hermenêutica que propõe a interação criativa, e não a oposição lógica, do mito e do culto de Dioniso, eis o propósito estrutural da obra do eminente pensador Walter F. Otto. Não há, como afirma a visão moderna, racional e epistemológica, de um lado, o mito e, de outro, o culto, como se fosse a oposição entre a fantasia poética e a realidade empírica. Até mesmo a poesia e o culto, em sentido estrito, pressupõem originariamente "la existencia de una imagen del mundo mítica como su fundamento" (OTTO, 2006, p. 19). Somente superando a perspectiva lógica, que opõe o homem e o mundo, o inteligível e o sensível, o saber e o ser, enfim, o sujeito e o objeto, compreenderemos os fenômenos primordiais que envolvem o mito e o culto de Dioniso. O conhecimento não é simplesmente a visão única e racional do 
homem demasiado humano, mas a visão múltipla e dionisíaca do próprio ser do mundo.

O mito do nascimento de Dioniso revela, segundo Walter F. Otto, sua natureza misteriosa, ambígua e paradoxal. Antes de vir ao mundo, ardeu no fulgor produzido pelo divino pai e que também provocou a morte de sua mãe. Mas, foi salvo por este, que o abrigou em seu próprio corpo, dando-o à luz novamente no devido tempo. O deus "nascido duas vezes" representa o drama do sofrimento e da morte e, ao mesmo tempo, da alegria e da vitória. Ao deus doador de prazeres e loucuras, assim como às suas nutrizes e seguidoras (mênades ou bacantes), seriam também destinados padecimentos e mortes. As diversas epifanias de Dioniso revelam já de si a vida constantemente perseguida pela morte, a luz envolvida pelas sombras. Ainda menino, na forma taurina de "grande caçador" (Zagreus), o deus que sofre e morre foi esquartejado pelos Titãs e sobreviveu. Paradoxalmente, o mesmo deus que doa a embriaguez da vida faz experimentar, no mesmo instante, a morte e a embriaguez do aniquilamento. Assim, no mito e no culto, a face dionisíaca aparece tenebrosa, violenta e cruel, sendo muitas vezes associada à de um

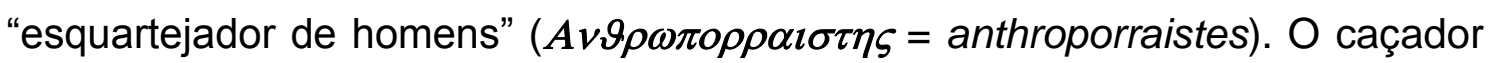
é também caçado, o esquartejador é também esquartejado: "El sentido del mito es que el dios padece en carne propia las monstruosidades que comete. Y lo que el mito narra, lo repite el culto en actos sacrificiales regulares" (OTTO, 2006, p. 81).

Dioniso é também um deus multiforme. No entanto, mais importante é a ambiguidade e contradição de sua própria natureza, que supera a de outros deuses. Múltiplo, mas sempre o mesmo, manifestando-se como um todo, e não apenas uma parte, do mundo. As epifanias dionisíacas se apresentam nas formas de vegetais (fitomórficas = videira, hera, pinheiro, figueira, murta), como unidade dos contrários luz e sombra, calor e frescor, vida e morte, quente e úmido, e nas formas de animais (teriomórficas = touro, bode, burro, leão, javali, urso, pantera, serpente), alguns como símbolos da fertilidade, do prazer e outros como emblemas de uma natureza sanguinária. Representam a união de beleza e perigo mortal que também encontramos nas suas companheiras 
(bacantes ou mênades). Segundo Eurípides, no coro de As Fenícias, até mesmo a Esfinge, enviada por Hades a Tebas, esse animal metade mulher e metade leão, que devora os homens, nos recorda muito a figura de Dioniso e suas Mênades: "[...] a Esfinge, / monstro implacável [...] / - flagelo insuportável enviado / por Hades dos infernos contra Tebas - / para espalhar o luto nesta terra" (EURÍPIDES, 1993, vv. 1024-1025 e 1031-1032, p. 154). Outros espíritos infernais, como as Erínias (Fúrias), também se assemelham ao cortejo dionisíaco, como podemos ver no coro das Eumênides, de Ésquilo:

\begin{abstract}
Em frente à nossa vítima cantamos / um hino dedicado às sacras Fúrias, / vertiginoso e delirante, a ponto / de provocar nos homens a loucura / e de lhes imobilizar a mente, / canto sem os acordes de uma lira / que os horroriza e os seca de medo. / O ofício que o destino inexorável / fixou e nos impôs eternamente / é perseguir todas as criaturas / lançadas por sua própria demência / na via tortuosa do homicídio / até descerem ao profundo inferno; / nem mesmo a morte as livrará da pena. / [...] Em sua insanidade Orestes cai, / sem perceber, num delírio que o perde / (é impenetravelmente negra a noite / que sua mácula envolvente estende / sobre seus olhos, como se o cegasse), / enquanto uma nuvem sombria desce e encobre todo o palácio paterno / de acordo com rumores aflitivos. (ÉSQUILO, 1991, vv. 442-455 e 493-500, p. 158-159).
\end{abstract}

Muitos outros exemplos confirmam a relação de Dioniso com o mundo dos mortos. Porém, segundo Walter F. Otto, o testemunho mais importante foi dado, no séc. VI a. C., pelo pensador originário Heráclito (fr. 15): "Mas Hades e Dionísio é o mesmo, para quem deliram e festejam." (ANAXIMANDRO, PARMÊNIDES, HERÁCLITO, 1991, p. 63). Tal relação se comprova, inclusive, em uma das principais festas fúnebres de Atenas (séc. VI-V a.C.) em homenagem a Dioniso: as Antestérias.

Símbolo da cosmovisão dionisíaca, a água é o elemento mítico e profético no qual habitam os segredos primordiais da vida e as origens do devir: "Revela, como él, una naturaleza dúplice, una clara, alegre, vivificante, y otra oscura, misteriosa, peligrosa, mortal" (OTTO, 2006, p. 119). O mistério da existência (nascimento e morte) e a questão do tempo (passado, presente e futuro), que envolvem deuses e homens, representam-se na visão mitopoética, material e dinâmica, da água. Afrodite surge do mar a partir da semente de Urano que flutua nas ondas. As ninfas, que alimentaram e criaram o recém- 
nascido Dioniso, são filhas das águas. Na llíada, de Homero (séc. VIII a. C.), afirma-se que Oceano é a origem de tudo e o pai dos deuses: "o rio-Oceano amplo-fluente, / Gérmen de tudo." [...] "o Oceano pai dos deuses" (HOMERO, 2003, XIV, vv. 200 e 250, p. 324 e 326). A ideia essencial do mito, diz-nos Walter F. Otto, sobrevive, inclusive, no pensamento de Tales e na filosofia de Aristóteles. Assim como nos mitos de Proteu e Tétis, as diversas metamorfoses de Dioniso confirmam sua semelhança e ligação com as águas eternamente moventes. Na llíada, Homero narra o mito de como Dioniso, acompanhado de suas ninfas (armas), foi perseguido por Licurgo, rei dos Edónios da Trácia, e buscou refúgio na profundidade do mar, onde foi acolhido amorosamente por Tétis:

De Baco as armas / Pelo sacro Nisseio perseguidas, / Picou-as de aguilhada, e elas no afogo / Deixam cair os tirsos; Baco mesmo, / De susto de um mortal, se atira às ondas, / $E$ trêmulo em seu seio o abriga Tétis. (HOMERO, 2003, VI, vv. 113-118, p. 164).

No mito e no culto de Dioniso, o elemento água não comparece apenas como força criadora e nutriz, mas também como potência destruidora e mortal, que se dissemina por todo o mundo vegetal, animal e humano. O vinho, o falo, o touro e o bode estão ligados às festividades e cultos como símbolos da epifania dionisíaca do êxtase e da loucura, do prazer e da dor, da fertilidade e da aniquilação, da vida e da morte. Na forma de touro, que emerge das águas, como atesta Plutarco acerca do culto em Argos, Dioniso não é só o símbolo da fertilidade e da força geratriz da vida, mas também a encarnação da fúria e do perigo mortal. Assim como as outras epifanias de Dioniso, o touro manifesta "la naturaleza doble del dispensador de vida y del aniquilador" (OTTO, 2006, p. 122). No touro, o elemento da vida se exalta até alcançar a fúria e o terror dionisíaco e se descarrega em um assalto de extrema virulência. Paradoxalmente, na forma de touro (Zagreu), o mesmo Dioniso é perseguido pelos Titãs e esquartejado. Nas Bacantes, de Eurípides, o coro ordena que Dioniso apareça na forma de touro:

Aparece em forma de um touro, de policéfalo dragão, ou de flamejante leonina prole! Vai, ó Baco, de face ridente, vai, e em tuas redes apresa o caçador das Bacantes, que já entre seus bandos funestos, jaz caído por terra. (EURÍPIDES, 1974, v. 1017, p. 51). 
Penteu vê Dioniso como touro enquanto, comicamente, caminha, disfarçado de mulher (Bacante ou Mênade), para assistir ao ritual das bacantes e experimentar seu desconhecido destino trágico, ou seja, ser esquartejado pela fúria de uma delas, sua própria mãe Ágave, que o confundiu com um leão e the arrancou a cabeça: "E tu, que me conduzes, não se diria que mudaste em touro? Cornos te nasceram na fronte! Acaso fera não terias sido sempre? Que um touro tu és agora" (EURÍPIDES, 1974, v. 918, p. 46). O touro, portanto, não é só o sujeito, mas também o objeto da violência que Dioniso pratica e sofre. No mito e no culto, o touro sacrifica e é sacrificado em memória do ser dionisíaco do mundo. Enfim, na forma vegetal (videira, hera), animal (touro, bode) ou humana (bacantes), Dioniso representa sempre o drama metamórfico da verdade que eternamente se oculta e se desvela em todos os elementos da natureza e da natureza humana: a finitude do ser.

Dioniso é a contradição que representa o mistério da vida inseparável da morte. Por isso, manifesta-se, no mito e no culto, como o deus da loucura, que brota da própria vida que se mostra abissal por obra da morte e que transgride todas as barreiras. Dioniso é, portanto, o revelador do mundo da loucura que existe na realidade das coisas, ou seja, da unidade dos opostos vida e morte, delírio e terror, grito e silêncio, presença e ausência. Afirma Walter F. Otto: "Dioniso, que los liga, debe ser el espíritu divino de una realidad monstruosa, de una esencia primigenia que justifica que se le llame loco incluso a él y que su aparición venga acompañada por la locura" (OTTO, 2006, p. 91).

Dioniso é o deus da loucura. A sua loucura combate as normas do dia, as leis da pólis, o princípio apolíneo de individuação. Dioniso, o deus louco, não é senão a experiência passional da vida. Nessa loucura de paixão se revela 0 mistério da vida que se renova. A abissalidade profunda e primordial da existência revela que a vida brota de sua própria morte. O mundo abissal de Dioniso é a loucura da própria manifestação do ser no tempo. 
A experiência de paixão dionisíaca revela-nos o ser da própria realidade. Nesta paixão, Dioniso é um personagente. Personagente não é senão um livre agente, senhor de si mesmo. Dioniso não se sujeita a qualquer medida. Não é o contraponto de Apolo, pois não é simplesmente o indisciplinado. O sentimento de liberdade dionisíaco não quer dizer simplesmente indisciplina, desregramento ou libertinagem. Quem assim o caracteriza não faz senão adotar o ponto de vista apolíneo da mesura de todas as coisas. Dioniso é o disciplinador de sua própria excessividade. É quem cria as suas próprias regras. A verdade apolínea é a exclusão da experiência sensível da vida. $\mathrm{O}$ princípio apolíneo de individuação tem por finalidade reprimir a verdade de novas experiências. Para o apolíneo, tudo o que não é puro, lógico, comedido, deve ser desprezado. Porém, Dioniso não é a versão contrária da pureza, da medida. É, por natureza, um diálogo de contrários. Portanto, conhecimento e paixão, mesura e desmesura, já fazem parte de sua personalidade. Dioniso é o impulso da vida em gestação.

Dioniso é o personagem por excelência da tragédia grega. A palavra personagem deriva de persona, que significa máscara. Dioniso está presente em todos os personagens trágicos. Não ser nomeado explicitamente nas peças trágicas, a não ser em As Bacantes, de Eurípides, onde comparece como personagem, não implica o seu desaparecimento. Como bem afirma Friedrich Nietzsche, em sua obra $O$ Nascimento da Tragédia, os personagens trágicos são "máscaras dionisíacas" (NIETZSCHE, 1992, p. 69). Conforme Walter F. Otto, a máscara dionisíaca é o símbolo do ser e do não-ser:

La máscara es en sí encuentro - y sólo encuentro, nada más que frente, no tiene envés -. [...] Es símbolo y apariencia de aquello que está y no está; unión de la presencia inmediata y la ausencia absoluta. (OTTO, 2006, p. 70, itálico do autor)

Dioniso é o deus do duplo domínio da vida e da morte. A máscara, então, simboliza o jogo do mundo. Noutros termos, simboliza as duas faces de uma mesma realidade em constante transformação:

Así, la máscara nos dice que la aparición de Dioniso, que se distingue de las otras divinidades por su evidencia y su imperiosidad, está 
ligada al enigma insondable de la duplicidad y la contradicción. Le hace irrumpir violentamente, inevitablemente, en el presente, al tiempo que lo desplaza hacia una infinita lejanía. Aterra por su proximidad, que, sin embargo, es distancia. Los misterios últimos del ser y el no ser observan al hombre con sus ojos monstruosos. (OTTO, 2006, p. 70-71)

No jogo da máscara, Dioniso é a representação da insubstancialidade da vida. A experiência dos abismos da existência revela-se como a experiência radical da finitude humana. De repente, dos abismos da existência irrompe os impulsos da vida. Essa irrupção do sentido está representada nas epifanias de Dioniso. A excessividade e a desmesura do seu aparecimento mostram o seu duplo aspecto.

Ainda segundo Walter F. Otto, Dioniso manifesta-se, em suas epifanias, como o deus da alegria e da tristeza, o doador da vida e da morte, enfim, como a união do celeste e do terrestre, do divino e do humano:

El que así nace no es únicamente el que grita de gozo y nos trae las
alegrías, también es el dios que padece y muere, el dios de la trágica
paradoja. Y la fuerza interior de este ser dúplice es tan poderosa que
aparece entre los hombres como una tormenta y los conmociona,
venciendo su resistencia con el azote de la locura. Todo lo usual y lo
ordenado debe ser reventado. La existencia se convierte
repentinamente en delirio... delirio de placer, pero no menos de terror.
(OTTO, 2006, p. 62)

Não é de surpreender que um deus como este tenha sido recusado pela civilização helênica. Afinal um deus transgressivo, excessivo e descomedido jamais faria parte da escola apolínea. No mínimo, seria excluído com o argumento de "dificuldades de convivência". Mas Dioniso subsiste na tragédia grega. A voz do deus fala de ocultas fontes. E Friedrich Nietzsche, que foi um dos grandes críticos dessa civilização da moral, dessa civilização da exclusão, dessa tradição metafísica ocidental, conhecia muito bem a verdade e a visão dionisíacas. Desde seus escritos e conferências de juventude, em 1870, na Universidade de Basiléia, Friedrich Nietzsche se apresenta como o grande precursor dos estudos hermenêuticos acerca da visão dionisíaca do mundo, conforme se verifica nos textos "A visão dionisíaca do mundo", "O drama musical grego" e "Sócrates e a tragédia grega" (NIETZSCHE, 2005, p. 3-44, 47- 
70 e 71-93, respectivamente). E o mesmo Nietzsche afirma, em 1872, em sua obra magna $O$ Nascimento da Tragédia:

[...] jamais, até Eurípedes, deixou Dionísio de ser o herói trágico, mas que, ao contrário, todas as figuras afamadas do palco grego, Prometeu, Édipo e assim por diante, são tão-somente máscaras daquele proto-herói, Dionísio. (NIETZSCHE, 1992, p. 69)

A máscara mostra os limites da individuação na sua forma externa. Mas, na sua forma interna, mostra o caráter abissal da existência humana. Nessa união de contrários, Dioniso se apresenta de uma maneira descomunal. Através da máscara é, ao mesmo tempo, menino e monstro:

\begin{abstract}
Na verdade, porém, aquele herói é o Dionísio sofredor, dos Mistérios, aquele deus que experimenta em si os padecimentos da individuação, a cujo respeito mitos maravilhosos contam que ele, sendo criança, foi despedaçado pelos Titãs e que agora, nesse estado, é adorado como Zagreus... Do sorriso desse Dionísio surgiram os deuses olímpicos; de suas lágrimas, os homens. Nessa existência de deus despedaçado tem Dionísio a dupla natureza de um cruel demônio embrutecido e de um brando e meigo soberano. (NIETZSCHE, 1992, p. 70)
\end{abstract}

Assim, a grandeza da interpretação nietzscheana está em mostrar que, na máscara, o dionisíaco e o apolíneo se encontram em luta permanente, não só no homem, mas, sobretudo, no próprio cosmos. Toda criação se manifesta como o próprio drama dionisíaco da vida que não cessa de morrer no horizonte finito do tempo, como assinala Friedrich Nietzsche, em sua obra $A$ Vontade de Poder: "Dionisos: sensibilidade e pavor. A transitoriedade poderia ser interpretada como gozo da força engendradora e destruidora, como criação constante" (NIETZCHE, 2008, p. 502). E dessa luta inesgotável de paixão e razão, surgiu a originalidade do drama trágico grego na antiguidade, cuja herança foi absorvida exemplarmente, entre outros, pelo drama moderno de Shakespeare, pelo romance moderno de Cervantes, pelo romance tragicômico de Machado de Assis, pelo romance personativo de Flaubert, Henry James, James Joyce, William Faulkner, Euclides da Cunha, Graciliano Ramos, Clarice Lispector e Guimarães Rosa. Enfim, é a partir do diálogo com essa tradição poética e dionisíaca que vai se estruturar hermenêutica, crítica e criativamente 
a escrita da morte na narrativa dramática $O$ Risco do Bordado, de Autran Dourado.

Baseando-nos na contribuição hermenêutica de Martin Heidegger e Hans-Georg Gadamer acerca da verdade do ser e do jogo da arte (Cf. PALMER, 1991; WEINSHEIMER, 1991), conforme vimos nos capítulos 1 e 2 , bem como na mundividência dionisíaca da tragédia grega, ora apresentada, mostraremos a seguir a importância dessas questões para a compreensão do problema hermenêutico do perspectivismo narrativo no romance contemporâneo e para a interpretação da narrativa predominantemente dramática e personativa de Autran Dourado. 


\title{
II. A NARRATIVA DRAMÁTICA DE AUTRAN DOURADO
}

\section{O PERSPECTIVISMO NARRATIVO E A ARTE DRAMÁTICA}

\begin{abstract}
"O autor, em sua obra, deve ser como Deus no universo, presente em toda parte, e visível em parte nenhuma."
\end{abstract}

Gustave Flaubert. Carta a Louise Colet.

\begin{abstract}
"A emoção trágica é, na verdade, um rosto olhando em duas direções, a do terror e a da piedade, sendo ambas fases dela. [...] Quero dizer que a emoção trágica é estática. [...] O espírito é detido e elevado acima do desejo e do ódio."
\end{abstract}

James Joyce. Um Retrato do Artista quando Jovem.

\subsection{O perspectivismo e a arte do romance}

O perspectivismo ou ponto de vista narrativo apresenta-se como função dominante do romance moderno e contemporâneo (LUBBOCK, 1976). Desde a revolução narrativa de Gustave Flaubert e Henry James, sobretudo em Madame Bovary (1857) e The Ambassadors (1903), respectivamente, não se trabalha mais simplesmente com o ponto de vista intruso, panorâmico e onisciente de um narrador que paira acima da experiência concreta da existência. Flaubert modula o foco narrativo, às vezes fala com a própria voz, às vezes fala através de uma personagem, passando da objetividade à subjetividade, da impessoalidade à pessoalidade, da exterioridade panorâmica à interioridade cênica de Madame Bovary: "Seu propósito é colocar a cena diante de nós, de modo que possamos compreendê-la como uma imagem que se desenrola aos poucos, ou como um drama representado" (LUBBOCK, 1976, p. 47). A arte dramática da ficção de Flaubert privilegia a história como um material a ser "mostrado, exibido de maneira que se conte sozinho" (Idem, p. 46, itálico do autor). Com o emprego do discurso indireto livre, sistematicamente apresentado pelo pretérito imperfeito, mistura de passado e presente, a narrativa de Flaubert se configura pela dupla mediação narrativa, 
ou seja, se estrutura como uma perspectiva ou voz dual (HERNADI, 1972, p. 32-43; PASCAL, 1977, p. 98-112). Funde a voz do narrador e a voz da personagem, a realidade e o sonho, a distância e a proximidade dos eventos narrados. Noutros termos, integra o realismo, a ciência e a racionalidade do narrador com o romantismo, a experiência e a sensibilidade da personagem. $O$ discurso indireto livre também é conhecido como falsa terceira pessoa ou monólogo narrado (COHN, 1966, p. 97-112; Idem, 1978, p. 99-140), pois diferencia-se da terceira pessoa tradicional e onisciente. Deste modo, a questão da verdade, da subjetividade e da alteridade apresenta-se, no romance moderno e contemporâneo, problematizada em prol da abertura do sentido da existência. A verdade não aparece mais como adequação do personagem ao ponto de vista absoluto do narrador. A verdade prévia da razão é colocada à prova na experiência finita e sensível do existir. O personagem não é mais um sujeito idêntico, mas um sofredor dos impactos da existência e reconhecedor das várias vozes que o habitam (BAKHTIN, 2010). Negado o estatuto do personagem tradicional, irrompe a alteridade qualitativa da existência. A relação entre o personagem (homem) e o universo narrado (mundo) é perspectivada e até multiperspectivada como forma de mostrar que a existência humana não é conceitual, idêntica, mas passionalmente dramática. A experiência humana acontece, sobretudo, por imagens e não, simplesmente, por conceitos. Neste sentido, a verdade da existência é um processo de desvelamento, a subjetividade é negada em prol da despersonalização e a alteridade é o reconhecimento do outro em si mesmo. O romance contemporâneo não descreve, porém dramatiza uma experiência, mostrando como esta adquire significação e provoca transformação na existência de personagens inseridos no horizonte finito do tempo.

\subsection{A narrativa personativa e a técnica do refletor}

Iniciando-se com Flaubert e radicalizando-se com Henry James, principalmente em seus últimos romances publicados entre 1900 e 1904, The Ambassadors, The Wings of the Dove e The Golden Bowl, e em seus "Prefácios" (JAMES, 1984; Idem, 2003), teorizando lucidamente acerca da arte 
do romance, a questão do ponto de vista narrativo é levada às últimas consequências por grandes romancistas como, por exemplo, Marcel Proust, James Joyce, Virgínia Woolf, William Faulkner, Thomas Mann, Franz Kafka, Robert Musil, Hermann Broch, Machado de Assis, Euclides da Cunha, Graciliano Ramos, Clarice Lispector, João Guimarães Rosa, Adonias Filho, Osman Lins e Autran Dourado. Na verdade, a contribuição de Henry James para os escritores do século XX está no fato de transformar o romance numa arte que propõe a saída do autor ("exit author") que se intromete no texto para tecer comentários acerca de sua obra e de seus personagens (BEACH, 1932, p. 14-24). O autor intruso desaparece da cena e esta passa a ser apresentada através do fluxo de consciência, do monólogo interior e das impressões refletidas nas mentes dos personagens (FRIEDMAN, 1955; HUMPHREY, 1976; COHN, 1978). Na terminologia hermenêutica de Franz Karl Stanzel (1971), presente em sua obra fundamental Narrative Situations in the Novel: Tom Jones, Moby-Dick, The Ambassadors, Ulysses, o romance deixa de ser autoral (authorial novel) e passa a ser, predominantemente, personativo (figural novel) (STANZEL, 1971, p. 92-120). Entre o narrador e os eventos narrados, interpõese um ou vários personagens refletores ou máscaras narrativas. O narrador assume, então, o desempenho dramático do ator, metamorfoseia-se, despersonaliza-se, assume a máscara (persona), não fala em nome próprio, pois representa o papel de outra pessoa.

Como disse Gustave Flaubert, em carta a Louise Colet, datada de 9 de dezembro de 1852, a dramaticidade, impassibilidade ou impessoalidade da arte é a finalidade divina do criador: "O autor, em sua obra, deve ser como Deus no universo, presente em toda parte, e visível em parte nenhuma." (FLAUBERT, 2005 , p. 83). Importa assinalar que esta mesma tese flaubertiana da dramaticidade da arte e da impessoalidade do artista é reiterada por James Joyce em seu romance Um Retrato do Artista quando Jovem: "O artista, como - Deus da criação, permanece dentro ou atrás ou além ou acima de sua obra, invisível, aprimorado fora da existência, indiferente, aparando suas unhas." (JOYCE, 1992, p. 214). Portanto, a saída do autor intruso, na tradição flaubertiana da narrativa impessoal, como bem afirma Wayne C. Booth, não implica seu completo desaparecimento, pois ele continua presente como autor 
implícito, responsável pela organização estrutural da obra e mantendo um grau de distanciamento em relação ao leitor, ao narrador, ao refletor e aos demais personagens. (BOOTH, 1961, p. 269-374)

No romance personativo, a imagem narra o próprio evento no "aqui" e "agora" da experiência do personagem. O narrador é a própria imagem e não o autor ou o personagem. Para Henry James, que se apresenta como grande seguidor da técnica flaubertiana, a arte do romance não é senão o jogo dramático da ficção e da realidade, da literatura e da vida (JAMES, 1984; EDEL, 1963; WELLEK, 1972, p. 202-225; JUNKES, 1997, p. 131-158). A arte do romance trabalha com a condensação e a dramaticidade da experiência humana. A vida no horizonte finito do tempo é a arte do romance de Henry James. $\mathrm{O}$ aqui e o agora da experiência finita são refletidos na consciência do personagem. O romance torna-se dramático ao trabalhar com a integridade da experiência humana: o sentimento, o pensamento e a vontade. $A$ arte não descreve, mas dramatiza a experiência humana no horizonte finito do tempo. Os acontecimentos ou os impactos da existência são filtrados pela mente dos personagens e as suas impressões sensíveis são apresentadas ao leitor no instante mesmo em que ocorrem. A projeção dos sentimentos e pensamentos do personagem produz uma tensão dramática no romance. Importa a transformação existencial do personagem através das experiências concretas da vida. A arte do romance e a vida do personagem são construídas, reconstruídas e desconstruídas simultânea e paulatinamente. Na tensão da vida e da morte, a existência do romance e o romance da existência interagem continuamente.

A situação narrativa personativa, segundo Stanzel, no capítulo "The Figural Novel: The Ambassadors", apresenta as seguintes feições características:

withdrawal of the author; predominance of scenic presentation; the reader's center of orientation fixed in the now-and-here of a novel figure or of an imaginary observer on the scene of the action; and the possibility of giving the epic preterite the imaginative value of the present. (STANZEL, 1971, p. 92) 
Esta situação personativa implica a despersonalização, pois o "eu" se reconhece "outro". A situação é mimética e patética, pois a apresentação é cênica (gestual, emocional e dramática). A arte do romance personativo é a representação cênica (Mimesis) do ser do personagem na experiência finita do tempo (MENDILOW, 1972; POUILLON, 1974; MEYERHOFF, 1976). Há o espelhamento da ação na consciência de um personagem que testemunha (eye-witness) os eventos, no momento mesmo em que ocorrem.

Conforme nos diz James Joyce, outro grande seguidor e radicalizador da técnica de Gustave Flaubert e Henry James, bem como inaugurador de uma poética não-aristotélica e de uma teoria da prosa epifânica e do efeito trágico, em seu romance Um Retrato do Artista quando Jovem, a mimesis personativa é o drama encenado de modo estático, e não cinético (Cf. CONNOLLY, 1962, p. 266-271; LEVIN, 1973; DE ANGELIS, 1989; SÁ, 1993, p. 168-192; ECO, 2000).

A emoção trágica é, na verdade, um rosto olhando em duas direções, a do terror e a da piedade, sendo ambas fases dela. [...] Quero dizer que a emoção trágica é estática. [...] O espírito é detido e elevado acima do desejo e do ódio. (JOYCE, 1992, p. 205)

Noutros termos, o drama estático é a suscitação trágica do que verdadeiramente existe na experiência finita do tempo. A apresentação cênica (ante oculos ponere) e o visualismo patético colocam o leitor diante do jogo dramático da existência, num espaço e tempo delimitados. Mostrar a experiência ao leitor enquanto esta se reflete na mundividência do personagem, eis a arte do romance contemporâneo. Portanto, a prosa epifânica não é simplesmente a revelação de uma alma (psicologia), mas, sobretudo, o desvelamento do sentido trágico da existência (ontologia). O drama não é de ação, mas de paixão: "A arte é a disposição humana de matéria sensível e inteligível para uma finalidade estética" (JOYCE, 1992, p. 207). O homem aprende pelo sofrer (pathei mathos), eis a fórmula esquiliana-joyceana da arte dramática.

A beleza expressa pelo artista não pode despertar em nós uma emoção que seja cinética ou uma sensação que seja meramente física. Desperta, ou deve despertar, ou induz, ou deve induzir, uma estase estética. (JOYCE, 1992, p. 206) 
A situação personativa está marcada por uma forte ambiguidade. As imagens da ficção e da realidade, do mundo e do homem, da vida e da morte passam a ser intercambiantes e indistintas na experiência concreta do personagem. A plenitude do tempo mostra-se pontilhada pela finitude do ser. A experiência humana é, portanto, a experiência trágica da finitude do ser no tempo. Como veremos no capítulo 5, "O drama de paixão em $O$ Risco do Bordado", na narrativa personativa de Autran Dourado, que incorpora também a estrutura da tragédia grega, pode-se afirmar, seguindo as palavras de Emmanuel Carneiro Leão, que "A tragédia não é uma condição simplesmente humana. É o ser da própria realidade" (LEÃO, 1991, p. 11).

A perspectiva interna ou temporal desta situação narrativa está, proustianamente, associada também com a percepção espacial (POULET, 1992). A modulação do ponto de vista provoca uma modulação do espaço. Deste modo, a narrativa personativa produz a perspectivação do real. A interação das pessoas e das coisas no espaço é perspectivada em vários ângulos. Abre-se um leque de perspectivas a partir do refletor narrativo. E a relação do tempo e do espaço, no romance personativo, pode ou não ser perspectivada. Na perspectiva interna, a representação da consciência dá-se pelo modo refletor que cria a imediaticidade do evento, isto é, a ilusão da mirada direta no pensamento e sentimento dos personagens. Os eventos narrados aparecem ao leitor no instante mesmo em que ocorrem. Enfim, o espelhamento dos acontecimentos na consciência de um ou vários personagens caracteriza em definitivo a situação narrativa personativa.

Com base nessas considerações acerca do perspectivismo narrativo e da arte dramática do romance personativo, propostas por Gustave Flaubert, Henry James e James Joyce, bem como na mundividência dionisíaca da tragédia grega e na revolução cervantina do romance moderno e barroco, interpretaremos a seguir a estrutura passional, lúdica e labiríntica da narrativa dramática O Risco do Bordado, de Autran Dourado. 


\title{
5. O DRAMA DE PAIXÃO EM O RISCO DO BORDADO
}

\author{
"A morte ensina muitas coisas, ele aprendia." \\ Autran Dourado. O Risco do Bordado, \\ II, "Nas Vascas da Morte".
}

O multiperspectivismo na narrativa dramática, passional e personativa $O$ Risco do Bordado, de Autran Dourado, tem sua fonte na obra moderna, barroca e lúdica de Miguel de Cervantes, principalmente no Dom Quixote (1605-1615). Assim, o romance moderno nasce questionando a visão cartesiana, filosófica, científica, racional e unilateral do mundo. Como bem afirma Milan Kundera, "o fundador dos Tempos Modernos não é somente Descartes mas também Cervantes" (KUNDERA, 1988, p. 10).

\begin{abstract}
O romance acompanha o homem constantemente e fielmente desde o princípio dos Tempos Modernos. A "paixão de conhecer" (aquela que Husserl considera como a essência da espiritualidade européia) se apossou dele então para que ele perscrute a vida concreta do homem e a proteja contra "o esquecimento do ser"; para que ele mantenha "o mundo da vida" sob uma iluminação perpétua. (KUNDERA, 1988, p. 10-11)
\end{abstract}

Na revolução moderna do romance cervantino, o foco múltiplo permite uma compreensão nova, ambígua e relativa do mundo com o objetivo de questionar o predomínio da verdade absoluta. A verdade do mundo e o mundo da verdade não se revelam em uma visão parcial. A múltipla perspectiva torna complexa a revelação da verdade. Muda-se o ponto de vista, muda-se também o objeto visado. A interação dialética entre o ver e o visto não é a relação lógica entre um sujeito e um objeto. No multiperspectivismo cervantino, não há a oposição polar, mas o jogo da ficção e da realidade, da literatura e da vida, do homem e do mundo, da vida e da morte (BALLESTER, 1975; FUENTES, 1989; SILVA, 2001). Não se tem, portanto, um sujeito cartesiano enclausurando 0 mundo no espaço de sua subjetividade imperial.

No romance personativo O Risco do Bordado, de Autran Dourado, a herança cervantina do multiperspectivismo barroco torna-se a visão prismática que se reflete na mente do personagem-metáfora-artista João da Fonseca 
Nogueira. Cervantes e Autran Dourado jogam com espelhos ou com prismas. Mediante um processo de reflexão, adicionam ao romance uma dimensão a mais. Cervantes anuncia, assim, a técnica dos escritores modernos e contemporâneos, segundo a qual o evento é refletido na mente de um ou vários personagens que o vivenciaram. As imagens refletidas no espelho da consciência produzem o efeito da duplicidade. Mostram um lado e, simultaneamente, ocultam um outro. Mostram que a ficção e a realidade, o invisível e o visível, a morte e a vida são um e o mesmo. As imagens produzem o efeito dramático da existência. Velázquez, em Las Meninas, e Cervantes, em Dom Quixote, conseguiram este efeito dramático e abissal, conforme nos ensinam Michel Foucault e Helmut Hatzfeld (FOUCAULT, 1990, p. 19-31 e 6165; HATZFELD, 1988, p. 239-255 e 257-270). A modernidade literária nasceu, portanto, com o romance auto-consciente, lúdico e irônico de Cervantes (BAKHTIN, 1988, p. 397-428; REED, 1981, p. 71-92).

Assim, a narrativa dramática, epifânica e personativa de Autran Dourado se estrutura na correlação lúdica e labiríntica dos sete blocos narrativos que configuram o livro da memória, o retrato do artista, personagem-refletormetáfora João da Fonseca Nogueira, a saber: I. Viagem à Casa da Ponte; II. Nas Vascas da Morte; III. Valente Valentina; IV. As Voltas do Filho Pródigo; V. Assunto de Família; VI. O Salto do Touro e VII. As Roupas do Homem. Segundo o crítico Fábio Lucas (1973), em seu texto "O sete-estrelo de Autran Dourado", o escritor mineiro tomou "sete pontos, sete episódios dramáticos, e formou com eles uma constelação de mitos" (LUCAS, 1973, p. 139). No livro todo, há "um jogo permanente entre memória e imaginação, entre o mundo real e o mundo fantástico, entre a maturidade e a infância - mistura de razão e de paixão" (Idem, p. 140). Cada bloco narrativo obedece à lei geral ou interpretante hermenêutico que denominamos a arte como jogo e escrita da morte. Noutros termos, a unidade e multiplicidade dos blocos narrativos se traduz numa tensão harmônica de contrários: medo e desejo, vida e morte, sonho e realidade, razão e loucura, literatura e existência, mito e realidade.

A referida lei narrativa é responsável pela interação do plano da enunciação (narrador) e do plano do enunciado (fábula, personagens, espaço e 
tempo) de O Risco do Bordado. Autran Dourado não trabalha com os métodos realistas tradicionais de composição da narrativa nem no nível do discurso nem no nível da história. Abandona a mediação unívoca e onisciente do narrador assim como a concepção lógica do personagem. Adota, portanto, a dupla mediação narrativa de um narrador personativo e de um personagem-refletor condizente com a natureza ambivalente e paradoxal do mundo e do homem. Seguindo os passos da revolução narrativa moderna de Cervantes, Flaubert, Henry James e James Joyce, Autran Dourado configura sua obra como intercâmbio dramático da arte e da verdade, do sonho e da realidade, da razão e da paixão, da escritura e da leitura.

O Risco do Bordado é uma narrativa predominantemente personativa. O narrador assume o desempenho dramático do ator ao se metamorfosear em diferentes personalidades. Entre o narrador e os eventos narrados interpõe-se o personagem-refletor João, que vivencia sensível e criticamente os acontecimentos. Desde o início da obra, o leitor é colocado diante de uma estrutura dramática de composição ou dupla mediação narrativa que envolve a racionalidade arquitetônica do narrador-personativo e a passionalidade existencial do personagem-refletor. Nesse movimento lúdico de exterioridade e interioridade, de objetividade e subjetividade, de impessoalidade e pessoalidade, de distanciamento e proximidade, compõe-se a estrutura narrativa lúdica, labiríntica e complexa de O Risco do Bordado.

Autran Dourado não se limita a narrar eventos consecutivos ou ações progressivas regidas por uma causalidade ideológica ou psicológica. A sua narrativa não é linear, fechada, horizontal, pois não segue a lógica aristotélica de início, meio e fim. A narrativa em blocos é dramatizada, fragmentada, aberta e vertical. A leitura de O Risco do Bordado implica, portanto, uma nova disposição do leitor que deve assim colher o sentido não só do que é dito, mas também do que é silenciado e sugerido no texto. A narrativa dramática é um jogo de desvelamento e velamento do sentido vivenciado cognitiva, afetiva e volitivamente pelo personagem-refletor-metáfora João. 


\subsection{A estrutura lúdica de composição ou Planta baixa}

No texto "Planta baixa de um livro", incluído em Uma Poética de Romance: Matéria de Carpintaria (2000a, p. 69-79), Autran Dourado oferecenos um quadro, roteiro, planta baixa ou fio da meada, à maneira de outro mestre da carpintaria, James Joyce, em seu Ulisses (1922), em que divide, interna e imanentemente, em três grupos, os sete blocos narrativos de $O$ Risco do Bordado, com o objetivo de desvelar as múltiplas técnicas do perspectivismo narrativo (plano da enunciação ou do discurso) e sua interação com a posição do personagem-refletor João, do espaço e do tempo (plano do enunciado ou da história).

Essa planta baixa revela os andaimes da concepção da obra de arte autraniana e sua construção lúdica, lúcida, rigorosa e vigorosa. Trata-se de uma verdadeira máquina e carpintaria que mostra "a força e beleza da proporção, do balanceamento, do ritmo, da estrutura musical, temática e sinfônica de O Risco do Bordado" (DOURADO, 2000a, p. 78-79). A obra de arte não é fruto da inspiração, mas da engenharia racional e da imaginação criadora do artista que produz uma "machine à emouvoir" (Le Corbusier), uma "máquina de comover".

No texto "Da necessidade de uma arte poética", incluído em Uma Poética de Romance: Matéria de Carpintaria (DOURADO, 2000a, p. 15-23), Autran Dourado diz-nos que aprendeu essa "lição de coisas", interação artística de razão e sensibilidade, sobretudo, com os grandes criadores, críticos e artesãos da arte narrativa (Cervantes, Goethe, Flaubert, Gide, Henry James, Marcel Proust, Kafka, James Joyce, William Faulkner, Thomas Mann, Hermann Broch...) e da arte poética modernas (Poe, Baudelaire, Rimbaud, Mallarmé, Valéry, Eliot, Drummond, João Cabral...). Todos eles também realizaram um diálogo concriativo com os mestres da poesia épica (Homero, Virgílio) e dramática da antiguidade (Ésquilo, Sófocles e Eurípides) e da modernidade (Shakespeare) 
O primeiro grupo (lírico) utiliza a técnica rememorativa e se compõe de 3 blocos ou narrativas:

I. Viagem à Casa da Ponte - Personagem principal.

II. Nas Vascas da Morte - Personagem principal.

III. Valente Valentina-Personagem principal, obscurecida.

O $1^{\circ}$ grupo é uma espécie de "retrato do artista quando jovem", ou a sua "educação sentimental". Nestas histórias ou blocos da narrativa geral, João é o personagem principal. Os membros de sua família "biblica" aparecem ligeiramente, são pequenas sombras (terão maior importância no $2^{\circ}$ grupo), pequenas manchas aqui e ali, mais para marcar o ritmo narrativo, embora a disputa ou ciúme de vovô Tomé por tio Maximino seja um prelúdio, em surdina, do seu ciúme em relação ao irmão pardo Teodomiro, em Assunto de Família. (DOURADO, 2000a, p. 76)

O segundo grupo (bíblico) utiliza a técnica narrativa pura, ancestral e se compõe de 3 blocos ou narrativas:

IV. As Voltas do Filho Pródigo - Personagem principal, obscurecido.

V. Assunto de Família - Personagem oculto, é o avô que conta para ele.

VI. O Salto do Touro - Personagem principal, obscurecido.

O $2^{\circ}$ grupo, o "bíblico", como sempre o chamei, se constitui de "biografias" de três pessoas-chave da família de João - o tio, o avô, a tia - apenas mencionados no $1^{\circ}$ grupo: o avô, como disse, mais acentuadamente no II e III blocos; a tia, apesar de sua importância enorme no livro, muito vagamente, um ponto aqui, outro ali; os tios, Alfredo e Zózimo, no I, dois pingos. É através da aparição desses personagens ou de referências a eles, que vou obtendo um ritmo, que vou ligando as pontas dos fios narrativos, amarrando as linhas da composição.

Neste $2^{\circ}$ grupo, no bloco IV, As Voltas do Filho Pródigo, João ainda é personagem, o que serve de ligação deste grupo com os blocos do grupo anterior; no V, Assunto de Família, João é sujeito oculto, apenas ouvinte, pois o caso é narrado em falsa terceira pessoa, sendo o avô quem fala, João com ele se identificando no remorso e na culpa; e finalmente, em $O$ Salto do Touro, bloco VI, é ele o narrador: embora a história seja também escrita na terceira pessoa, é dele João o ponto de vista. (DOURADO, 2000a, p. 76-77)

O terceiro grupo (mítico) utiliza a técnica de ciranda, descritiva-narrativa, recorrente e compõe-se de 1 só narrativa:

VII. As Roupas do Homem.

$1^{\circ}$ subgrupo (descritivo-mítico-épico). Personagem secundário, narra e assiste. 
$2^{\circ}$ subgrupo (narrativo retrospectivo). Personagem que pergunta para ouvir.

$3^{\circ}$ subgrupo (narrativo indireto). Personagem que não aparece, mas a narrativa é resposta a pergunta sua.

$4^{\circ}$ subgrupo (narrativo indireto, retrospectivo). Personagem que não aparece, mas a narrativa é resposta a pergunta sua. Diferente do anterior por ser narrativa através de interposta pessoa. De Felícia, pela boca do dr. Alcebíades ao menino.

$5^{\circ}$ subgrupo (narrativo conclusivo). Como no $3^{\circ}$ grupo, o personagem não aparece, mas a narrativa é resposta a pergunta sua.

O $3^{\circ}$ grupo, como disse, compõe-se de uma só narrativa, dividida em cinco versões diferentes e contraditórias. É como que uma revisitação, uma recorrência, uma desmitificação de todos os sonhos do menino, dos temas do $1^{\circ}$ e $2^{\circ}$ grupos. Revisitação e recorrência através de uma volta ao passado, de uma viagem à infância e adolescência de João, um embarque no tempo pelo conduto de um mito, o jagunço Xambá, que aparece nos outros blocos apenas uma vez, não me lembro quando, acredito que no $1^{\circ}$ bloco. (DOURADO, 2000a, p. 77)

À semelhança de outras obras literárias que se utilizam da estrutura lúdica de composição em blocos ou episódios abertos e autônomos, mas que se comunicam numa unidade vertical, como Odisseia (Homero), Dom Quixote e Novelas Exemplares (Miguel de Cervantes), Educação Sentimental e Bouvard e Pécouchet (Gustave Flaubert), O Processo (Franz Kafka), Ulisses (James Joyce), Vidas Secas (Graciliano Ramos), Autran Dourado se notabiliza também como um artista consciente do seu ofício, um artesão ou arquiteto que trabalha minuciosamente o ritmo narrativo interno de suas obras, visando à simetria, ao paralelismo e à composição sinfônica. A narrativa em blocos, portanto, possibilita um novo arranjo, uma nova leitura e uma nova interação entre os sete episódios narrativos de $O$ Risco do Bordado, abrindo-se numa multiplicação de sentidos, rigorosamente calculada. Razão e paixão, realidade e sonho, ordem e mito, cosmos e caos são os símbolos ou metáforas dessa obra lúdica, labiríntica e arquitetonicamente construída em sua integração dos planos da enunciação e do enunciado, do narrador personativo e do personagem-refletor João, do espaço e do tempo narrativos. 
A narrativa autraniana cada vez mais incorpora os procedimentos poéticos dos gêneros épico, lírico e dramático num diálogo profícuo da literatura arcaica e moderna. Torna-se necessária, portanto, uma hermenêutica narrativa poeticamente condizente com a complexidade estrutural de uma obra que promove o intercâmbio da poesia e da filosofia, do sensível e do inteligível, da ficção e da história, da literatura e da existência e que se configura radicalmente comprometida com a desconstrução da metafísica onto-teo-lógica do conhecimento ocidental.

Nesse sentido, defendemos a tese de que a narrativa dramática de Autran Dourado se configura hermeneuticamente como arte, jogo e escrita da morte. Noutras palavras, a escrita da morte na vida ou a interação dialética dos contrários é a estrutura lúdica que fundamenta e articula a correlação dos blocos narrativos de O Risco do Bordado, de Autran Dourado. Segundo o crítico Ronaldes de Melo e Souza (2010a), em seu texto "Agonia e morte em Autran Dourado", nas fições narrativas do escritor mineiro, "o drama agônico da vida sempre se representa como trama da morte" (SOUZA, 2010a, p. 163). Assim, na genealogia narrativa do personagem-refletor João, o familiar e 0 estranho são perspectivados pelas imagens dinâmicas do ser e do não-ser, da vida e da morte. Através da refletorização da consciência de João, o personagem-metáfora (DOURADO, 2000a, p. 218-230), as imagens da vida e da morte são apresentadas, proliferadas e condensadas como experiência concreta do mundo. No labirinto anímico de João, o desvelamento da vida e o velamento da morte configuram o jogo simbólico do mundo. Neste sentido, o sexto bloco narrativo, O Salto do Touro, comparece como a matriz estrutural ou interpretante hermenêutico que configura a escrita da morte como a interação das partes (unidade) e do todo (multiplicidade) de O Risco do Bordado. Nas palavras de Autran Dourado:

O clímax, nódulo ou tônica da narrativa maior está no bloco $\mathrm{VI}, \mathrm{O}$ salto do touro, e não no último, o mais extenso deles, dividido em cinco partes, As roupas do homem. Na ordem propriamente cronológica em que foi escrito o livro, e não no arranjo que dei, o último bloco que compus foi o VI e não o VII, que na ordem de escrita foi o segundo, embora eu já tivesse o livro todo organizado, desde quando o concebi, partindo de Viagem à casa da ponte, que nasceu primeiro. (DOURADO, 2000a, p. 68) 
$\mathrm{Na}$ unidade e multiplicidade dos blocos narrativos de $O$ Risco do Bordado, a morte se apresenta como tema diversamente modulado que envolve tanto o plano da enunciação quanto o plano do enunciado. A escrita da morte implica a compreensão da estrutura trágica e finita do conhecimento do homem e do mundo. No nosso entendimento, tal compreensão se traduz na própria estrutura dramática de composição da narrativa autraniana. Com o objetivo de elucidar hermeneuticamente esse jogo de des-velamento da verdade da morte na obra de arte autraniana, é que passamos agora à interpretação dos sete blocos narrativos de O Risco do Bordado.

5.2. Os blocos narrativos ou Poema de sete faces

\begin{abstract}
"Quando nasci, um anjo torto desses que vivem na sombra disse: Vai, Carlos! ser gauche na vida."

Carlos Drummond de Andrade. "Poema de sete faces".

"Porque Eu é um outro. [...] O Poeta se faz vidente por meio de um longo, imenso e racional desregramento de todos os sentidos."
\end{abstract}

Arthur Rimbaud. Carta a Paul Demeny.

Os sete blocos narrativos de O Risco do Bordado constituem, no nosso entendimento, as sete faces do mundo dionisíaco, da obra labiríntica, da narrativa personativa, do refletor ou personagem-metáfora João, dramática, passional e rigorosamente arquitetadas por Autran Dourado. Representam a "constelação de mitos" ou o "sete-estrelo" de Autran Dourado, como bem nos disse o crítico Fábio Lucas (1973, p. 137-143). Mito e ordem, caos e cosmos, paixão e razão constituem a lei paradoxal ou unidade dual deste multiverso autraniano.

Desde o primeiro bloco narrativo, Viagem à Casa da Ponte, nos encontramos no meio do caminho da vida e embarcamos em direção às 
origens do mundo ou à infância do ser de mãos dadas com o personagemrefletor-metáfora João. Experimentamos a aurora e o sentimento do mundo pelo olhar sensível do menino que descobre o mundo e a si mesmo num movimento lúdico de luz e sombras, desejo e medo, sensibilidade e pavor. Como a criança dionisíaca, João é a metáfora, o refletor ou o símbolo da vida e da morte, pois não cessa de nascer e morrer, de experimentar e sofrer os impactos e as epifanias da própria existência. Alegria e dor acompanham o menino e nos acompanham no próprio ato da leitura desta narrativa personativa de Autran Dourado. Pela técnica do refletor narrativo ou da falsa terceira pessoa, somos transportados para o mundo mítico-poético de Duas Pontes. Embarcamos numa aventura que não é somente épica, mas simultaneamente lírica e dramática. No "barco ébrio" da narrativa personativa, da visão mítica, da infância poética e do novo espírito literário de João, o poeta vidente, experimentamos o "desregramento de todos os sentidos" e a verdade dramática e paradoxal de que o cosmos é também o caos, a razão é também a paixão e, sobretudo, de que o "Eu é um outro" (RIMBAUD, 2009, p. 38, itálicos nossos) nas etapas do caminho da vida.

A falsa terceira pessoa da narrativa personativa autraniana rompe com a lógica da narrativa realista-naturalista-científica de que a subjetividade (eu) está separada da objetividade (ele). Misto de narrativa autoral (épica) e narrativa de primeira pessoa (lírica), a narrativa personativa (dramática) problematiza os tradicionais métodos de análise e interpretação do ponto de vista narrativo que dividem a tipologia do narrador em terceira pessoa (externa) e primeira pessoa (interna) com relação aos eventos narrados. O Risco do Bordado exige uma hermenêutica que suplante a epistemologia dos estudos tradicionais acerca do perspectivismo narrativo. Lírica, narrativa e drama se correspondem na modernidade de Autran Dourado. A revolução da lírica moderna de Edgar Allan Poe, Charles Baudelaire, Arthur Rimbaud, Stéphane Mallarmé, Fernando Pessoa, Carlos Drummond de Andrade e João Cabral de Melo Neto encontra sua correspondência também na narrativa moderna de Cervantes, Flaubert, Henry James, Marcel Proust, James Joyce, William Faulkner e Autran Dourado. O narrador personativo é a máscara dionisíaca que representa o drama da 
indistinção da vida e da morte, da presença e da ausência, do ser e do não-ser, da proximidade e da distância, do sensível e do inteligível, do eu e do outro.

A arte poética da narrativa autraniana não descreve simplesmente, mas, sobretudo, sugere ou encena o sonho da realidade que não cessa de se transformar a partir de seu próprio mistério. A falsa terceira pessoa é a integração dinâmica e dramática da objetividade (impessoalidade, distanciamento e racionalidade) e da subjetividade (pessoalidade, proximidade e sensibilidade), seja na lírica ou na narrativa modernas. Se "Deus é que sabe por inteiro o risco do bordado", como afirma o ditado mineiro que Autran Dourado coloca como epígrafe a sua obra Uma Poética de Romance: Matéria de Carpintaria (2000a), onde reflete criticamente sobre a construção mítica e arquitetônica de $O$ Risco do Bordado, fica claro que o autor, nessa narrativa personativa, lúcida e ludicamente, ironiza e relativiza a certeza dessa verdade. $\mathrm{Na}$ narrativa personativa de Autran Dourado, o artista é o próprio deus-autorcriador da verdade lúdica de seu mundo-obra-bordado. Ele se representa dentro e fora, visível e invisível, intimizado e indiferente, sentimental e irônico no seu próprio mundo.

Seguindo os passos e promovendo o intercâmbio da visão mito-poética da antiguidade, da narrativa e da lírica moderna autoconsciente, assim como do romance personativo de Flaubert a Joyce, Autran Dourado concriativamente fez de Minas, assim como Carlos Drummond de Andrade e Guimarães Rosa, nas palavras do crítico Silviano Santiago, seu "mínimo universo" (SANTIAGO, 1988, p. 5) literário. Diferentemente da paideia filosófica ou tradição metafísica platônico-cristã, a narrativa dramática de Autran Dourado propõe a paideia poética que reintegra o divino e o humano, o inteligível e o sensível, o espírito e o corpo em sua unidade, duplicidade e multiplicidade.

Assim, viajamos com o personagem-refletor-artista João em busca do tempo perdido, do ser esquecido no pretérito e, finalmente, redescoberto no presente como saber de experiências feito, inventando, dionisiacamente, a partir do tecido ou bordado da memória, a própria vida como obra de arte. Do grão nulo do nada, da morte, do que desapareceu no tempo, borda-se épica, 
lírica e dramaticamente o novo ser da narrativa e da experiência do refletor João. Segundo Autran Dourado, há debaixo das histórias de O Risco do Bordado uma outra história, "uma história subliminar e simbólica" (DOURADO, 2000a, p. 51), um palimpsesto, desenho ou risco que vai nos enovelando (narrador, refletor, leitor, a obra, a vida). A morte, é, portanto, o risco do nosso texto e da nossa vida.

Assim como Duas Pontes, a sociedade mítica ou pólis autraniana, não se manifesta apenas como geografia, mas como símbolo do cosmos e do caos, também o personagem-metáfora João e a própria obra $O$ Risco do Bordado comparecem como união dos contrários humano e divino, vida e morte, distante e próximo, antigo e moderno, escrita e finitude, texto e palimpsesto. Há uma estrutura hermenêutica e arquitetônica na composição poética de Autran Dourado que interliga as partes e o todo de sua narrativa dramática. Duas Pontes e seus habitantes, João e sua família, a obra e seu escritor, o autor e o leitor, a presença e a ausência, os vivos e os mortos, todos são máscaras dionisíacas que desvelam a consentida contradição ou duplicidade do mundo e do homem.

Uma hermenêutica ontológica da narrativa condizente com o universo mitopoético de Autran Dourado, que compreenda e interprete as Duas Pontes, que caminhe simultaneamente no espaço e no tempo de sua obra, que enfrente a duplicidade do seu cosmos e caos, ou seja, a lei geral ou estrutural de suas narrativas dramáticas, eis o propósito de nossa investigação. A obra, a cidade Duas Pontes, o personagem-metáfora João, o autor e o leitor, o narrador e os eventos narrados se nos apresentam como a macro e microestruturas que se interagem e regem o movimento lúdico e a estética da formatividade da obra de arte de Autran Dourado.

A obra, a cidade, o narrador personativo e o personagem-refletor são imagens poéticas da união de contrários. Máscaras ou epifanias dionisíacas do mundo e do homem. Autran Dourado se destaca como o artista que concilia a ciência e a experiência da narrativa, a teoria e a reflexão crítica acerca da arte do romance. Não só escreve narrativas que se espelham metalinguisticamente, 
como elabora ensaios teóricos que são verdadeiras narrativas ficcionais. Duas Pontes é o símbolo do mundo ficcional e reflexivo de Autran Dourado. Um poetar pensante e um pensar poético caracterizam a sua mundividência artística. A metaficção comparece como a metáfora do escrever e do existir. $O$ risco do bordado não é apenas a imagem metafórica da obra, do artista e do personagem, mas, sobretudo, do próprio mundo dramático de Autran Dourado visto telúrica, mítica e poeticamente como a contradição, duplicidade ou complementariedade da vida e da morte.

Em O Risco do Bordado, a obra, o mundo Duas Pontes, o narrador personativo ou o personagem-metáfora João não têm idade cronológica, progressiva, sucessiva. O narrador, a fábula, os personagens, o espaço e o tempo não são delimitados, não têm forma definida. Tudo se apresenta neste livro diante dos olhos do leitor como visão mítico-poética, metamorfose e epifania incessante do mundo e do homem. A vida e a morte, o céu e a terra, o prazer e a dor, a escrita e a leitura, a literatura e a experiência, o mito e a realidade, o eterno e o efêmero, o ser e o não-ser constituem a unidade lúdica e dramática da obra autraniana. Não estamos diante de um mero livro de memórias, de uma narrativa tradicional de eventos consecutivos, de um sujeito narrador em oposição a um objeto narrado. A visão ou posição científica do mundo pouco nos auxilia na compreensão do universo mítico e multifacetado de Autran Dourado. O Risco do Bordado estrutura-se como visão mítica, poética e dramática do mundo. A narrativa dramática de Autran Dourado ( $O$ Risco do Bordado) e a poesia dramática de Fernando Pessoa ("Ulysses") revelam muito bem que, ao contrário do que demonstra a visão científica, a verdade do mundo, da obra de arte e do homem é paradoxal: "O mytho é o nada que é tudo" (PESSOA, 1986, p. 6). O que está em jogo não é a causa prévia, mas a origem mítica da narrativa do mundo e do homem. O narrador personativo de O Risco do Bordado é um "narrador de mitos" (KERÉNYI, 2011, p. 21), pois retorna, regressa ou retrocede ao tempo primordial e originário, não ao tempo cronológico. Não narra as memórias do que passou ou aconteceu, mas do que não cessa de acontecer no passado, no presente e no futuro. A situação narrativa personativa de Autran Dourado é a representação dramática do próprio acontecer do ser no horizonte finito do tempo. 
Os sete blocos narrativos de O Risco do Bordado repetem o tempo primordial, mítico, do acontecer do ser no tempo. Sempre o mesmo e sempre diverso, épica, lírica e dramaticamente, o eterno retorno do mesmo. Não se busca, não se narra o ser eterno, a verdade pré-estabelecida (a causa, orthotes), mas o eterno ser, a verdade acontecedora (a origem, alétheia) que se vela enquanto se desvela. O risco (palimpsesto) do bordado (texto) é a própria busca (escrita) da morte. Narrar assim não é descrever, mas des-cobrir ou inventar o ser. Narrar o risco (o que se vela) do bordado (o que se desvela) equivale a fundar o mundo. A narrativa autraniana é uma cosmogonia. Uma nova narrativa (dramática) e um novo narrador (personativo) implicam um novo mundo (Duas Pontes) e um novo homem (João). Um novo deus (autor) implica um novo mundo (obra).

Em suas meditações poético-pensantes "Proposições sobre o autor e sua obra", incluídas no livro O Meu Mestre Imaginário (1982), Autran Dourado confirma-nos, lúdica e lucidamente, nas palavras de seu outro eu ou persona ficta Erasmo Rangel, a conexão que faz entre a narrativa e a cosmogonia ou entre o autor implícito e a obra:

\footnotetext{
$\S$ Entre a obra e o autor se faz um mundo.

§ A obra é um mito, um fio de meada em direção ao incógnito final. O autor nunca vê, senão como um sonho (mito de um mito), o panorama do que fez.

$\S$ Por mais intrincado que seja o labirinto (a obra pronta e acabada; melhor - durante e depois principalmente), há todavia um autor. Por mais que ele se disfarce, procure desaparecer na própria obra.

$\S$ A imagem de Flaubert (o autor presente porém invisível na obra, como Deus na criação), repetida por Joyce, traduziu o sonho que ambos perseguiram.

§ Pronta a obra (o labirinto), quem nela habita? Ou ela é uma máquina, um convite à entrada, à viagem, à aventura - ao risco? (DOURADO, 1982, p. 24-27)
}

A obra é uma arquitetura, um labirinto. O autor é um construtor, criador de mundo (Dédalo). A obra e o criador não se separam. O mundo, o labirinto e o minotauro representam o próprio artista. $\mathrm{O}$ artista projeta e persegue a morte, mas também é perseguido por ela. Escrever é escrever-se, reconhecer-se outro. Escrever é ser outro. Morrer e renascer. O mito de Dédalo (artista- 
arquiteto) é uma epifania dionisíaca. Dioniso e o minotauro, Dédalo e o labirinto, o risco e o bordado, a obra e o criador, a vida e a morte são um e o mesmo.

A perspectiva ou situação narrativa apropriada para entrarmos no multifacetado labirinto ou mundo da obra de arte de Autran Dourado não é, como bem nos revela o crítico Silviano Santiago, em seu texto "Autran Dourado: Questão de perspectiva" (SANTIAGO, 1985, p. 7-8), a perspectiva realista-naturalista-regionalista, mas a perspectiva mítica, arquitetonicamente trabalhada por James Joyce, sobretudo em Um Retrato do Artista quando Jovem e Ulisses (Cf. ELIOT, 2001, p. 59-61). Os planos da enunciação e do enunciado da narrativa autraniana não se configuram pelos métodos tradicionais de composição. Assim como não encontramos uma mediação narrativa unívoca e centralizadora (plano do discurso) também não encontramos um personagem, um espaço e um tempo idênticos a si mesmos (plano da história).

Noutras palavras, Autran Dourado não segue a tradição romanesca, monológica e cartesiana do realismo formal, caracterizada pelo predomínio da racionalidade, da materialidade e do individualismo modernos (WATT, 1990, p. 11-33; Idem, 1997, p. 60-99), mas a tradição poética e dialógica do quixotismo exemplar, regida pelo romance como dramatização, autoconsciência, ficcionalidade, alteridade e multiperspectivação da realidade, do autor, do leitor, do personagem, do eu, do mundo, do ser e da verdade (BAKHTIN, 1988, p. 397-428; REED, 1981, p. 19-42 e 71-92), enriquecida, sobretudo, pela visão mitopoética de Homero e dos trágicos gregos Ésquilo, Sófocles e Eurípides, pela mundividência lúdica e barroca de Cervantes, pela refletorização de Flaubert e Henry James e pela representação da consciência pluripessoal de James Joyce e William Faulkner (Cf. AUERBACH, 1971, p. 471-498; NEUHAUS, 1971, p. 118-144; HUMPHREY, 1976, p. 79-90 e 94-101; FRIEDMAN, 1955, p. 210-243).

A aparente fragmentação (caos) da forma narrativa de $O$ Risco do Bordado é regida pelo rigor de uma composição labiríntica e arquitetônica 
(cosmos). Mito e ordem, caos e cosmos, loucura e razão, eis a lei paradoxal da narrativa autraniana. Trata-se de um narrador que é simultaneamente arcaico e moderno, capaz de conciliar a visão mítica da antiguidade com a visão racional da modernidade. Ao caracterizarmos a narrativa personativa de Autran Dourado, deixamos bem claro não só a complexidade de sua construção, mas também a complexidade de sua interpretação. Uma nova forma narrativa implica, portanto, um novo leitor, lúcido e crítico, capaz de se aventurar nesse romance-mar-labirinto-mundo movente que é também a existência humana. Passamos, então, à leitura hermenêutica dos sete blocos narrativos de $O$ Risco do Bordado.

\subsubsection{Viagem à Casa da Ponte ou A origem mítica do mundo}

Este primeiro bloco narrativo inicia o primeiro grupo (lírico) que se utiliza da técnica rememorativa. Apresenta-nos a situação narrativa personativa em sua complexidade. Estamos diante de uma cena em que, predominantemente, o narrador não representa a si mesmo, não se intromete na obra, e não se coloca como mediador único emitindo juízos acerca dos eventos narrados. $\mathrm{Na}$ aparência inicial de uma narrativa tradicionalmente épica, panorâmica, objetiva e distante, a obra logo se desdobra numa narrativa modernamente dramática, cênica, subjetiva e próxima. O narrador personativo é um ator dramático, pois se despersonaliza, representa um outro ser, encena o drama do personagemrefletor João, seus medos e desejos, suas descobertas do sexo, suas indagações acerca do mistério da Casa da Ponte, "o mundo fechado, o reino proibido".

Foi Zito quem contou como era por dentro a Casa da Ponte. Não podia acreditar, não acreditava se não fosse Zito. Um menino daquela idade entrar na Casa da Ponte! Se fosse Tuim por exemplo, João tinha dado uma boa gargalhada. Tuim era fino e ligeiro na mentira. Com Zito era diferente, tinha de acreditar. (DOURADO, 1999c, p. 9)

Neste trecho inicial do livro, percebemos a duplicidade da narrativa personativa ou falsa terceira pessoa. Passamos da apresentação, exterioridade ou distância épica ("contou”) à disposição, recordação ou proximidade lírica do 
personagem-refletor João ("Não podia acreditar, não acreditava..."). Do pretérito perfeito ao imperfeito dá-se a passagem da exterioridade à interioridade de João. A partir dessa ambiguidade de vozes (narrador e refletor), de espaço (exterior e interior) e de tempo (pretérito e presente), desse aqui e agora da consciência reflexiva, sensível e questionadora de João, vamos acompanhar a viagem mítica, a paideia poética, a educação sentimental ou a configuração do retrato do artista João em seus fluxos de consciência, monólogos interiores ou narrados em $3^{\text {a }}$ pessoa.

A viagem que ora se apresenta e envolve o leitor não é só exterior ou física (Casa da Ponte), mas, sobretudo, interior ou anímica (refletor João). Na leitura da obra, a odisseia de João e a odisseia da narrativa se dão nas águas correntes do ser e nas terras moventes da cidade de Duas Pontes. A ambivalência ou dupla mediação narrativa, a voz dual do narrador e do refletor, o intercâmbio de razão e sensibilidade constituem a arte como jogo de desvelamento da verdade da narrativa dramática de Autran Dourado.

A experiência da escritura, da leitura e do refletor se identificam na narrativa autraniana. Experimentamos a duplicidade da narrativa (narrador e refletor) assim como João experimenta a duplicidade da existência (amor e morte, desejo e medo, atração e repulsão).

A narrativa dramática incorpora elementos da estrutura épica e lírica, transformando-se numa verdadeira prosa poética, que acompanha a educação sentimental e irônica do menino. Os múltiplos estilos da escrita autraniana acompanham as multicores com que João enxerga a Casa da Ponte e a si mesmo.

O casarão prenhe de segredos, com suas janelas fechadas de dia e acesas à noite, povoava a imaginação fragmentada e os "sonhos diurnos" do menino. Mundo de luzes e de sombras, assim como as suas habitantes. Numa verdadeira imaginação quixotesca, a narrativa e o refletor João transfiguram o prosaico em poético, a realidade em sonho, o grotesco em sublime e viceversa. 
As habitantes da Casa da Ponte, "segregadas e famosas", também oscilam em seu ser, pois, segundo os olhos do menino, "perdiam à luz do dia muito da legenda dourada". E, segundo as mulheres casadas da cidade, "eram a chaga, o pecado, a perdição de Duas Pontes": "Na Casa da Ponte é que elas realmente viviam, viviam uma vida mítica. Eram como ninfas: de noite à luz de candeias volantes, saíam a cantar pelos bosques." (DOURADO, 1999c, p. 10)

A emotividade de João ao pronunciar o nome da ninfa amada ("Ai, meu Deus, Teresinha Virado!") traduz o drama de sonho e realidade, prazer e dor do menino. Na experiência sensível e inteligível de João, Teresinha "tinha o condão de movimentar a máquina dos sonhos". Nesse sentido, a Dulcineia de Dom Quixote e a Teresinha de João se identificam no poder passional de suplantar a racionalidade do ser e do mundo. Sugerir ou ficcionalizar o mundo, eis o sonho.

\footnotetext{
Mas de noite, choralua, quando o mundo se apagava, a carne fremia quente, era o nome que ele repetia. Teresinha Virado, Teresinha Virado, ai Teresinha Virado! E as mãos trêmulas, o peito arfando, os olhos compridos e macerados, via a Casa da Ponte iluminada lâmpadas azuis e avermelhadas, pasto de memoráveis fantasias. (DOURADO, 1999c, p. 10-11)
}

Zito, menino de quinze anos, que devido à pobreza foi trabalhar na loja de seu Bernardino, era o melhor amigo de João. Como nas narrativas míticas, regidas pelo ritual da morte e do amor, Zito será o guia no rito de iniciação de João nos segredos da Casa da Ponte (Cf. LEPECKI, 1976, p. 18-59). Na ânsia de saber, João se abismava nas angústias dos sentidos oscilando entre a dúvida e a confiança, admirando o amigo como um mestre da verdade, mas também se sentindo pequeno e imaginando-se abandonado futuramente por ele.

João ia empilhando as peças de brim e divagava longe. Não é possível, como é que Zito foi na Casa da Ponte? Zito era sério e compenetrado, bem taludo e espichado é verdade, mas pouco mais velho do que ele, as mulheres não deixariam ele entrar. De noite, então, de jeito nenhum! Só se tivesse sido de dia. Mas como, por causa de quê? [...] Só se fosse mentira de Zito. Mas Zito não era de mentir nem de contar vantagem. Tuim, sim. [...] Estive lá na Casa da Ponte, foi só o que disse Zito. Não podia ter escutado mal, ouviu 
claramente. Zito tinha aberto a porteira do mundo. (DOURADO, 1999c, p. 12)

Mas João logo pensa na possibilidade de Zito ter se aproximado de Teresinha Virado, e sente uma "dorzinha funda no coração".

E Teresinha Virado? Será que ele viu Teresinha Virado? [...] Era demais se ele tivesse falado com Teresinha Virado. Não queria nem pensar. [...] Machucado, quase chorando, não queria nem pensar. Não, de jeito nenhum Zito falou com ela, nunca tocou num fio de cabelo de Teresinha Virado. Os homens podiam fazer tudo com ela, Zito é que não. (DOURADO, 1999c, p. 14)

$\mathrm{Na}$ experiência conjunta do ser e do tempo, do sonho e da realidade, o menino vive mortalmente os instantes epifânicos da aprendizagem sensível:

\begin{abstract}
Nunca para ele uma espera durou tanto num átimo assim tão pequeno. O coração carregado, lampejos, vislumbres. Teresinha Virado faceirosa tinha uns modos de olhar de quem promete tudo, um riso rasgado e claro que brincava com a amargura do menino, deixava-o intrigado de ciúmes. João fugia de pensar, não deixava de pensar. Num lusco-fusco viu tudo. Teresinha Virado passou de leve os dedos nos cabelos de Zito. Eram demais suportar tamanha semvergonhice. Teresinha cascalhava, e o riso de Teresinha Virado era lama na alma esfarrapada. Ele me paga se é mentira, ele me paga se é verdade! Fazia qualquer coisa de ruim com ele. Ela não estava lá, Zito nunca viu de perto Teresinha Virado! Conhecia tanto Teresinha Virado quanto ele, menos do que ele - Zito nunca teve o seu poder de sonhar. (DOURADO, 1999c, p. 15)
\end{abstract}

A narrativa personativa de Autran Dourado não é uma prosa de descrições, mas uma prosa de momentos epifânicos que desvelam a indistinção do sonho e da realidade, do ser e do não-ser, do eu e do mundo. Ela mistura não só as vozes do narrador e do refletor, como também as vozes dos interlocutores, João e Zito, reestruturando assim a forma narrativa tradicional. Os fluxos de consciência tornam fluidas as fronteiras sintagmáticas do discurso. E o "catecismo" de João sonda as margens do sagrado e do profano, questionando o amigo entre silêncios e palavras, curiosidades e receios.

Quando foi? Na hora do almoço, as onze horas. Que é que você foi fazer lá? Fui levar umas caixas de sapato pras mulheres experimentarem. Seu Bernardino é que mandou? Foi. Você acha que eu ia sozinho? [...] 
Como é que ele ia fazer pra falar naturalmente de Teresinha Virado sem que o outro conhecesse todo o seu segredo? [...] Você viu todas? Acho que sim. Mas todas mesmo? [...] Mas que confessionário! Deixa eu perguntar. Tinha algum homem lá? Acho que não. [...] Das que a gente conhece faltava alguma? Não, acho que não. Ah, disse João fingindo esquecimento, e Teresinha Virado? Ara, seu! eu falei todas elas, não falei? Teresinha Virado estava com um roupão de cetim com ramagens, disse Zito. (DOURADO, 1999c, p. 16)

Um dos motivos recorrentes nesta obra, que confirma sua vinculação a uma narrativa mito-poética do ser e do mundo, a uma verdadeira cosmoantropo-gonia literária, é o da imaginação material e dinâmica dos elementos água e fogo (Cf. BACHELARD, 1989b; Idem, 1994). Símbolos da vida e da morte, da profundidade e superficialidade do ser, correlacionados à visão epifânica e dionisíaca do mundo, a água e o fogo são os correlatos objetivos das disposições anímicas do refletor João, que passa agora da realidade ao sonho. A palavra, neste mundo mito-poético da infância, ainda tem o dom de transfigurar a realidade.

As águas paradas, escuras, que dormiam no fundo do peito do menino se agitaram ligeiras, espraiando-se em grandes círculos, quando o silêncio de ansiedade e espera se partiu, Zito dizendo Teresinha Virado estava com um roupão de cetim com ramagens. E as ondas que corriam eram agora lentas, quentes, irreais, desmaiadas: as pancadas lentas e desmaiadas e quentes dos sinos no sonho. Uma alegria medrosa incendiou a alma pequena no seu silêncio de êxtase. O cetim lustroso (o brilho louro estalando dos cabelos de Teresinha Virado) dançava batido pelo vento: vela enfunada, bandeira colorida. E a música em surdina, grave e cheia, solene e grave (as notas longas de um órgão na nave de uma igreja), espalhava a sua alegria impura e pecaminosa na alma desamparada do menino. E antevia Teresinha Virado caminhando: os passos macios de dança, o roupão brilhoso, as ramagens coloridas, os joelhos, o pedaço da coxa que aparecia enquanto ela caminhava a sua dança por entre nuvens. E ele sentia a macieza morna do cetim no rosto, as penugens macias do peito das rolinhas. E o coração batia apressado, pulsava miúdo o coração de uma rolinha. E toda a sua alma medrosa se inundava da presença diáfana de Teresinha Virado. (DOURADO, 1999c, p. 17)

O narrador personativo arma a cena para que o leitor veja pela integração dos sentidos (visão, audição, olfato, tato, paladar) do refletor a junção e a disjunção do sonho e da realidaade, de Teresinha Virado e da paisagem circunstante. 
Quê que foi, perguntou Zito. Vamos logo com esse tambor. Nada, disse João olhando a Serra de dona Mazília verde de cafezais. Todas estavam de roupão? Verde-ramagem, cetim cheiroso, o cheiro dos cafezais. Os frutos vermelhos nos galhos, doces, o rosado da carne, o cetim macio para os dedos. (DOURADO, 1999c, p. 17)

Como não lembrar aqui o poetar pensante ou o olhar sensível do heterônimo mestre Alberto Caeiro, na poesia dramática de Fernando Pessoa, também herdeiro da tradição moderna, romântica e simbolista que instaura a desconstrução da metafísica, promove a integração dos sentidos e desvela a visão e a verdade epifânicas do mundo?

Eu sou um guardador de rebanhos.

O rebanho é os meus pensamentos

$\mathrm{E}$ os meus pensamentos são todos sensações.

Penso com os olhos e com os ouvidos

$\mathrm{E}$ com as mãos e os pés

E com o nariz e a boca.

(PESSOA, 1986, O guardador de rebanhos, X, p. 146)

E assim o refletor João viaja, vai e volta, na reversibilidade da realidade corporal à idealidade anímica, na elevação e queda do ser, no diálogo com Zito. E assim se dá o convite para conhecer fisicamente os segredos da Casa da Ponte.

Depois, muito depois uma pequena fagulha açulou de esperança a alma do menino. E os sapatos serviram? Você não vai voltar lá mais, perguntou. Zito olhava-o bem nos olhos. Num instante pareceu perceber tudo. Não agradaram, disse ele. Fiquei de voltar lá amanhã, com mais umas pilhas. Você quer ir comigo? João não podia falar, fez que sim com a cabeça. (DOURADO, 1999c, p. 18)

O narrador personativo nos inicia também, assim como Zito ao amigo, no ritual ou na viagem da experiência do tempo e do ser, do sagrado e do profano, do medo e do desejo do refletor João.

Foi então que começou a longa viagem à Casa da Ponte.

João ficou zanzando pela cidade, embrulhando o tempo, fugia de encontrar algum conhecido. Não queria falar com ninguém. Chegava em casa quando a janta já na mesa. Temia falar de frente com a mãe, ela podia ver: a alma pecaminosa, à flor da pele, boiava negra como manchas de óleo ou gasolina. [...] Assim João ficou fugindo pela cidade, sem rumo, boiando no azul, no cinza da tarde. (DOURADO, 1999c, p. 18) 
O ser crepuscular da alma, de João e da tarde, boiava em multicores na cidade. Impossível separar o menino e o mundo na visão mito-poética, simultaneamente épica e lírica, da narrativa. "Entre o menino e as coisas, entre o mundo e a alma, um muro se erguia". Entre o comedimento e o descomedimento, as fronteiras do ser e do saber.

\begin{abstract}
Apenas olhos, João procurava se fixar numa realidade inteiramente diversa de tudo o que estava se passando dentro dele. João se adestrava nas artes de esconder, de fugir. [...] $\mathrm{Na}$ aventura da percepção, buscava esquecer a si próprio, o coração pesado, ganhava uma cara simples e cerrada como o pai às vezes, indevassável, intata. As mãos não se mexiam, a comida esfriando no prato. (DOURADO, 1999c, p. 19)
\end{abstract}

Nesse perspectivismo narrativo, João é visto, interiormente, pelo narrador e leitor, e, exteriormente, pelo pai e pela mãe. Nos segredos do ser, o leitor sabe mais que alguns personagens do texto. Na técnica personativa do livro, vemos, sentimos e ouvimos o que se passa na mente transparente do personagem-refletor João.

Queria ficar sozinho no pensamento, muito além dos longes da serra. Vivia numa névoa doce e molemente melancólica. Nem mesmo Zito agora ele queria ver. O pensamento coleava os flancos da serra, serpeava longas distâncias. A alma buscava as planuras verdes, para além do azul. As ramagens verdes. (DOURADO, 1999c, p. 20)

A escrita de Autran Dourado se nutre de metáforas, colagens e montagens, de imagens recorrentes, como no trecho "as ramagens verdes" que nos faz lembrar a descrição das roupas de Teresinha Virado feita por Zito. João vê a natureza transfundindo-a na imaginação da amada. Mais uma vez se confirma que a narrativa não se atém à descrição e ao realismo, mas sim mobiliza o simbolismo como sugestão ou indeterminação do real, dos oscilantes estados de alma do refletor. $O$ menino se educa sensivelmente imergindo na natureza ambígua e reticente.

Procurava os lugares mais afastados da cidade. Foi até ao bosque dos eucaliptos da estrada de ferro, cheirou o ar fino e frio. [...] Pisava as folhas secas, de olhos cerrados ouvia no silêncio o zunido do vento, cheirava o ar embalsamado.

No pasto de seu Quincas, o cheiro bruto do capim gordura. Dava uma gastura grossa, arranhando o nariz por dentro. [...] No curral, o cheiro quente das vacas apartadas. O mugido longo, chorado, de um 
bezerro. O cheiro fresco, grosso, ardido, das bostas. Não pisar nas grandes rodelas, por causa do mijacão. Uma cigarra rachou contínua o silêncio espraiado do pasto. (DOURADO, 1999c, p. 21)

\begin{abstract}
Chega então o dia esperado e desesperado de viajar à Casa da Ponte com o amigo Zito. No caminho, o eu sensível e o eu racional de João entram em conflito. $\mathrm{Na}$ in-decisão, a vida sendo estrangulada pela morte, o ser pelo saber.
\end{abstract}

\begin{abstract}
João carregava duas pilhas de caixa de sapato amarradas por um cordão, Zito outras duas. João procurava andar depressa, não queria ser visto carregando aquelas caixas. A coisa podia chegar nos ouvidos do pai. E se encontrasse o pai pela rua, quê que havia de dizer? Não fosse a decisão de Zito, tinha vontade de desistir. Tudo durante a tarde do outro dia, tudo que enchera de sonhos e magias a noite passada, parecia coisa antiga. No fundo agora tinha medo de ir à Casa da Ponte, ver de perto Teresinha Virado. O coração carregado de sobressaltos e sinos e arrepios. Zito não me perdoa nunca se eu fugir agora, ia pensando. Mas o grande medo era outro, tentava esconder de si mesmo. Inútil fugir, o medo vibrava surdo: e se o pai aparecesse por lá? Pior: e se encontrasse o pai por lá? (DOURADO, 1999c, p. 21-22)
\end{abstract}

Na dúvida, entre a razão e a paixão, o medo e o desejo, o cosmos e o caos de si mesmo, João pergunta a Zito sobre o pai (o centro).

E se perguntasse a Zito, não era tão seu amigo? Melhor que guardar
aquele grande medo. Sufocava não falando. Zito, eu posso perguntar
uma coisa, você jura que não conta pra ninguém? Você promete, por
tudo quanto é mais sagrado, que esquece? [...] Você já viu meu pai
entrar alguma vez na Casa da Ponte? Ah, era isto? Nunca, disse Zito.
[...] Nem mesmo ouviu dizer que meu pai vai lá, perguntou João. Zito
se limitou a dizer seu pai não é disso, a gente vê logo. [...]
Não, nunca. João suspirou aliviado. O pai não era disso. A mãe,
coitada, ela podia ficar descansada. [...]
Suspirava aliviado. Ainda assim arrependido de ter vindo. O pai podia
vir a saber de tudo, a mãe (aqueles olhos que viam tudo, ela ficaria
vermelhinha só de pensar ele lá) descobria. Na sua pureza, na sua
brancura, na sua santidade - um tatuzinho, vermelhinha, ela não
podia nunca entender. Ela sabendo que ele tinha segurado os pés de
Teresinha Virado, ao menos tocado num fio de seus cabelos, nunca
mais que João podia pôr a mão nela. A mãe agora se encolhendo
vermelhinha quando ele Ihe encostava a mão, um tatuzinho. Se
antevia sujo, a pessoa mais suja do mundo. Não queria nem pensar
nisso, era nisso que não parava de pensar. (DOURADO, 1999c, p.
22-23) O refletor João vive e sofre, se acalma e se angustia pelo poder da linguagem, das palavras. A palavra des-cortinando o mundo e a alma, voltando à sua condição originária da verdade. Como afirma Autran Dourado, voltando 
ao "senso comum", não no sentido automatizado, estagnado (instrumental), mas dinâmico (poético). A palavra como des-velamento do sentido, como vida em metamorfose. O mito e o logos sendo as duas faces da mesma realidade, e não mundos metafisicamente separados. A palavra no seu movimento lúdico de ocultação e desocultação do sentido, descobridora da alteridade do homem e do mundo.

Não, ele nunca que seria forte e fechado feito o pai. Feito Zito agora, firme. Zito num grito seria homem, a gente via logo. Não sei como é que Zito ainda me dá a confiança de andar comigo. Se sentia humilhado. Via-se menino, mais menino do que nunca. Ai de mim. (DOURADO, 1999c, p. 23)

João vê Zito como um mestre, seguro de si, dono da palavra, o que sabe o caminho certo, e a si mesmo como um ser inseguro, inferior, tateando no escuro do mundo.

Zito proseava solene, dissertava. A segurança, a experiência, a sabedoria de Zito. João se sentia arrasado. Zito envelhecia a olhos vistos, por dentro já era um homem certamente. O que é que eu digo se me perguntarem? Não precisa dizer nada, deixa que eu digo, disse Zito. Mas o que é que você vai dizer? Zito estava soberano. Será que ele não vacilava? Será que nunca tinha medo? [...] Além do mais Zito era engenhoso, de uma mansidão calma, nunca que se afobava. Nada como trabalhar na loja de seu Bernardino e saber as coisas, um homem na vida. (DOURADO, 1999c, p. 24)

Diante do sobradão velho, João e Zito param. João estava assustado diante do desconhecido e assombrador. Já Zito, seguro. Aos sentidos do refletor, o sobrado aparecia paradoxal, mundo de sonhos e luz, de morte e vida.

Pararam diante do sobradão velho. As janelas fechadas, tudo parecia morto ou dormindo. O coração batia picado, socavante. As sombras germinavam, o sobrado crescia branco. Uma boca gigante que de repente podia se abrir, o casarão caiado de branco. As janelas verdes fechadas, as pálpebras pesando de sono. (DOURADO, 1999c, p. 25)

Cada etapa da viagem até à Casa da Ponte se dá como um rito de passagem, uma travessia do mundo sombrio ao mundo luminoso, do desconhecido ao conhecido, do não-ser ao ser. Não só do exterior ao interior, 
mas também dentro da casa, tudo se apresenta como um labirinto, enigmático, em que o sentimento da morte e da vida se apresenta a cada passo.

Agora os dois na grande sala de jantar dando para o quintal. O sol invadia a sala, uma luz ofuscante. Vindos do corredor escuro, os meninos custaram a se acostumar com a claridade. [...] Das muitas portas que se abriam para a sala, podia surgir a qualquer momento a primeira delas. Bem que podia não ser Teresinha Virado, pensou João agoniado. Outra metade dele dizia bem que podia ser ela. (DOURADO, 1999c, p. 26)

João experimenta o desregramento de todos os sentidos, enquanto espera na sala a chegada das ninfas.

Os sentidos se aguçavam, viviam intensamente uma vida de aranhas sensíveis. Ruídos abafados vindos do fundo da casa, o zunir de uma mosca teimosa nos ouvidos. Os olhos procuravam se acostumar com as coisas da sala. [...] A doce penumbra da sala se misturando com 0 cheiro da mangueira, com o cheiro mesmo da casa, úmido, sombrio. Tudo ruminando numa baba pegajenta, um espanto todo feito de atenção angustiada. O nariz, os olhos, os ouvidos abertos, a pele porosa, todo ele se escancarava às sensações novas. Previa, pressentia, ouvia as mulheres antes delas estarem ao alcance dos seus olhos, do seu nariz, dos seus ouvidos. (DOURADO, 1999c, p. 26)

Mas, em vez de encontrar a separação nítida, o refletor se surpreende diante da indistinção dos contrários: o sagrado e o profano, o extraordinário e o ordinário, o misterioso e o comum.

\begin{abstract}
Nunca imaginou que a casa pudesse ser assim. Uma sala comum, os mesmos móveis lá de casa, da casa de vovô Tomé, de todas as casas que ele conhecia. [...] até mesmo a surpresa de uma Santa Ceia na parede. Deus está em todos os lares, disse repetindo alguém. Em todos os lugares, corrigiu. Mas nunca que podia pensar Jesus comendo no meio daquelas mulheres. É verdade que Jesus sempre viveu no meio de gente ordinária, cercado de mulheres da vida. Era o que dizia tio Zózimo no desrespeito.

Tudo tão diferente do que ele imaginava. Nunca imaginara direito como devia ser por dentro a casa das mulheres. A Casa da Ponte era o mistério, jamais podia supor que as coisas ali dentro fossem iguais, tivessem a mesma matéria, a mesma existência do mundo lá de fora. Só o cheiro diferente (mas o cheiro de cada lugar é diferente), um cheiro nunca antes sentido ou imaginado, um cheiro que assinalaria para sempre dentro dele aquele lugar, aquela hora, aquela espera. (DOURADO, 1999c, p. 27)
\end{abstract}

Uma educação dos cinco sentidos, telúrica, e não uma visão racional e objetivadora do mundo, eis a arte narrativa e personativa de Autran Dourado. 
Não se narram fatos, mas encenam-se epifanicamente descobertas do sentido no horizonte móvel do tempo. Uma aprendizagem pelo sensível, um saber pelo experimentar e sofrer os impactos da existência, eis a fórmula esquilianaautraniana da arte e da narrativa dramática. E, assim, o refletor João vai descortinando o mundo e a si mesmo, no ritmo oscilante de euforia e disforia, imaginação e realidade, ser e não-ser, sublime e grotesco, sobretudo, quando as ninfas-mulheres comuns adentram a sala.

\begin{abstract}
A primeira que apareceu foi Lina. Vinha vestida de azul, o vestido muito curto, as mangas cavadas, os braços de fora, uns braços brancos de leite, o decote fundo, ele via um naco de seio. [...] João reparava na brancura leitosa dos braços gordos, no tostão da marca de vacina, no sovaco raspado, nas manchas de talco, no naco de seio. Ela recendia a Leite de Rosas, a perfume barato, enjoativo. Quando ela disse fiquem à vontade, viu uma falha de dente que ela forçava por esconder com um jeito de boca. (DOURADO, 1999c, p. 27-28)
\end{abstract}

Depois vieram Zilá, Felícia, Violeta e, por fim, Teresinha Virado. Seguese o ritmo das metamorfoses do real e da imaginação, da ilusão e da desilusão, da verdade e da não-verdade. Das máscaras do narrador personativo, do refletor e das habitantes da Casa da Ponte brota a verdade de que o ser e o nada são um e o mesmo.

\footnotetext{
Teresinha Virado de roupão vermelho, não de ramagens, mas de cetim brilhante, como ele esperava. Os olhos no chão, não podia ver Teresinha direito, mas reparava nos mínimos gestos, sentia a imensa presença. Uma hora viu: os cabelos soltos eram mesmo de um louro lustroso. Mas nunca podia imaginar aquela cor de ouro pálido, os cabelos tinham um brilho fugidio onde a luz brincava. Ela envolvia-o num perfume manso, vagaroso, penetrante. Teresinha Virado foi emudecendo o coração do menino. (DOURADO, 1999c, p. 28)
}

Neste ponto, a narrativa se quebra, silencia, deixa em aberto o que se passou depois na alma do menino com a chegada de Teresinha Virado. Assim, a estrutura fragmentada da narrativa autraniana não se constroi linearmente, cronologicamente, nem de um bloco narrativo para outro, nem no interior de um mesmo bloco, mas verticalmente. Como se pode verificar no seguinte trecho em que o narrador personativo arma a cena em que a indeterminação dos tempos se apresenta nos monólogos narrados do refletor João. Há pouco estávamos com ele na Casa da Ponte, diante de Teresinha Virado. Agora 
estamos num espaço, num tempo e num ser indefinidos. Num outro tempo futuro relembrando um outro tempo passado. Num outro tempo presente também indefinido, mítico em suas origens.

Depois, depois, como foi mesmo depois? Só depois, muito depois, já longe dali, noutro lugar, noutro tempo, outro coração, foi que João pôde juntar e separar dentro de si as variadas figuras do calidoscópio, a mistura confusa de cores, cheiros, gestos, risos e falas. A voz ciciante de Lina, a falha de dente, a pontinha da língua, o sovaco azul manchado de talco, a andadura de Teresinha Virado, o cetim brilhoso, os seios balançando soltos dentro do roupão, a presença que de repente iluminou toda a sala. As mulheres todas numa festa fantástica. Ninfas em concílio, liturgia, pura dança. Tonto, na hora parecia não ver, não ouvir, não sentir. As mulheres dançavam uma ciranda mágica sem fim, uma música em surdina, distante, só para ele. (DOURADO, 1999c, p. 28-29)

$\mathrm{Na}$ narrativa dramática, personativa e mito-poética de $O$ Risco do Bordado, a memória não é simplesmente a reprodução dos fatos passados, mas, sobretudo, o saber e a invenção do sentido possível. Busca-se, na lembrança, não a causa, mas a origem abissal do ser. Assim, a memória busca na morte (bíos), dionisiacamente, a imagem arquetípica da vida indestrutível (zoé), conforme nos ensina o estudioso da mitologia Karl Kerényi, em sua obra fundamental Dioniso: Imagem arquetípica da vida indestrutível (KERÉNYI, 2002, Vida finita e vida infinita na língua grega, p. XVII-XXII).

Mais tarde João ia relembrando aos poucos as mínimas coisas, os menores gestos, os ruídos mais apagados. Bastava querer, apertava os olhos, voltava-se para o coração assombrado, poço de águas escuras, ressoantes, profundas, cavas.

E surgia uma nova Teresinha Virado, uma Teresinha Virado inteira, perfeita na sua substância de sonho. Não era mais aquela Teresinha da primeira imagem, feita também de farrapos de sonhos, quando ainda não a conhecia, quando ainda não tinha segurado os seus pés, que essa primeira imagem, antevista no coração, a presença real de Teresinha Virado matara.

Teresinha Virado era muito real demais para o seu sonho. Lembrava as pernas raspadas (os cabelinhos espetados furando a pele), as coxas lisas, redondas, que de repente engrossavam bem em cima no escuro: quando ela cruzou as pernas estendendo o pé para ele calçar o sapato. [...] Um tremor incontido nas mãos, segurou a coisa quente que eram os pés de Teresinha Virado. [...] Mais que tudo, ele respirava o cheiro quente de carne, o cheiro das coxas entreabertas.

Teresinha Virado era de carne inteiramente diversa da carne que ele criara em sonho. Mas essa Teresinha de carne e osso, que matava a primeira Teresinha e apagava a imagem esfumada de neblina e emudecia os sinos da noite, tinha o condão de gerar uma nova Teresinha, um novo sonho, novos sinos na noite. 
De agora em diante Teresinha Virado vinha de roupão vermelho, deixando aparecer quando andava as chinelinhas de pano, os pompons de lã cor-de-rosa. (DOURADO, 1999c, p. 29-30)

Da intersecção do mundo imaginado e do mundo experimentado, brota uma nova Teresinha Virado. A realidade de "carne e osso" matou a realidade de "sonho e neblina", mas também fez nascer outra realidade de "carne e sonho". Assim, nem puro idealismo, nem puro realismo, a arte autraniana configura uma tensão harmônica de contrários, um novo simbolismo tanto no plano da enunciação (narrador personativo) quanto no plano do enunciado (personagem-refletor). Uma terceira margem sugerida e evocada, uma transcendência-imanente, um sonho-realidade, uma alma-corpo. A realidade da ficção autraniana é a ficção de sua própria realidade. A obra, o narrador, o refletor e o leitor desdobram-se, alteram-se, multiplicam-se. A metamorfose lúdica do "visto, ouvido, sentido" (DOURADO, 1999c, p. 30) é a lei de O Risco do Bordado. O ser não é, devém.

Deste salto labiríntico no tempo e no espaço, em que o refletor João, aparentemente adulto, está recordando e/ou inventando a experiência sensorial perdida e sofrida na Casa da Ponte, a narrativa que se quebrou retorna ao ponto em que os amigos saem da casa.

Ao saírem da Casa da Ponte, os meninos voltaram tão impressionados e calados que "não ousavam conferir o que tinham visto, ouvido, sentido". O refletor João é quem nos mostra os efeitos da visita/viagem ao "reino proibido".

Cheirou a camisa, cheirou o próprio corpo, cheirou as mãos. Um cheiro de água-de-colônia que fazia lembrar a alfazema da roupa de cama, só que mais grosso, mais oleoso, mais estridente. Um cheiro de Leite de Rosas, que Teresinha Virado passava nos sovacos raspados, nas pernas lisinhas. Um cheiro de carne quente e úmida. Um cheiro que ele nunca tinha visto em ninguém. Um cheiro estranho e penetrante, que não saía nunca, por mais que ele lavasse. Um cheiro que ficaria para sempre cheiro de mulher.

Entrou correndo em casa. João, gritou a mãe. Não respondeu, não podia responder. Se trancou no quarto, o coração pulando descompassado. Ai, a mãe podia ouvir, podia ver, podia sentir. Era agora um cheiro grosso, sumarento, berrante, que invadia todas as fibras do corpo, descia pelas raízes, encharcava o coração. (DOURADO, 1999c, p. 30) 
$\mathrm{Na}$ viagem de ida e volta, no espaço e no tempo míticos e indeterminados, do estranho ao familiar, no retorno à sua casa, João e o mundo não são mais os mesmos. $\mathrm{Na}$ aprendizagem de prazer e dor, na imaginação material ou dinâmica do fogo e da água, no desregramento de todos os sentidos, "um cheiro de carne quente e úmida" de mulher encharcava o seu coração. Epifanicamente, João sofre e conhece, na experiência do corpo, as metamorfoses dionisíacas do amor e da morte do ser.

\subsubsection{Nas Vascas da Morte ou O poeta é um fingidor}

Vimos, no bloco anterior, que o personagem-refletor João inicia ritualmente sua existência constantemente perseguida pela morte, pelo medo e pelo desejo. Impregnado pelo "cheiro de carne quente e úmida" de Teresinha Virado, João é a metáfora de paixão e morte, do remorso e da culpa, que "invadia todas as fibras do corpo, descia pelas raízes, encharcava o coração." (DOURADO, 1999c, p. 30). No texto "Uma segunda ordem de leitura", presente em Uma Poética de Romance: Matéria de Carpintaria (2000a, p. 48-51), Autran Dourado afirma-nos que o tema ou motivo do remorso e da culpa será recorrente em todo o livro, não só em João como em seus familiares.

Neste segundo bloco, regido pela situação narrativa personativa, encontraremos o personagem-refletor João, seguindo seu aprendizado pelo sofrer, no colégio interno em São Mateus, diante da experiência de agonia e morte de tio Maximino, que ele não conhecia pessoalmente, mas sabia que era brigado com vovô Tomé.

\footnotetext{
Há vários dias que tio Maximino estava para morrer. $\mathrm{O}$ velho morre não morre - já morreu, é pra hoje, no Colégio São Mateus só se falava nisso. [...] aquela agonia lenta que chegava a dar nos nervos e que deixava os meninos, o colégio, a cidade, suspensos de angústia, de medo. (DOURADO, 1999c, p. 31)
}

Os meninos do colégio, que gostavam de saltar o muro de seu Maximino Filgueiras para roubar fruta na sua horta e por enquanto não podiam, "viviam a 
demorada morte do velho". Mas João experimenta esse momento de outro modo.

No seu silêncio, na vagarosa tristeza que lhe deu (não sabia por quê, nunca tinha visto de perto aquele seu parente), súbito João voltou a ficar devoto. Ele que vinha perdendo a fé, matando missa, nem rezando mais de noite com Deus me deito, com Deus me levanto, com a graça de Deus e do Divino Espírito Santo. (DOURADO, 1999c, p. 33)

Uma atmosfera oleosa de morte tomava conta de tudo à semelhança da experiência com a Casa da Ponte e Teresinha Virado. João pensa na situação de vovó Naninha e vovô Tomé e se compadece deles.

\begin{abstract}
Respirava-se mal, o ar mesmo se tornou oleoso. E o óleo daquela morte escorria pelas paredes, pelos muros, pelo chão. Machava os cadernos, os livros, as roupas mofadas nos armários. Na testa de João porejava um suor pegajento que lembrava a febre e a agonia oleosa de tio Maximino. [...] Pensando em vovó Naninha, coitada, ela ia sofrer tanto quando soubesse que aquele irmão que ela não via há mais de vinte anos tinha morrido. Pensando em vovô Tomé, será que ele não ia sentir remorso quando soubesse daquela morte? [...] Pensando por fim na mãe, que certamente sonhava com ele João, de repente sentia uma saudade danada de casa. [...] E nos sonhos que tinha era a mesma atmosfera oleosa que não arejava o peito, antes sufocava. E o óleo escorria pelas paredes suadas, pelas ruas, pelos trilhos da Mogiana, pelas estradas, virava um rio grosso, ia bater em Duas Pontes, inundava as casas, a cidade inteira. (DOURADO, 1999c, p. 34)
\end{abstract}

$\mathrm{Na}$ imaginação do menino, assim como o reino proibido da Casa da Ponte, também o quintal de tio Maximino era prenhe de segredos.

Para João o quintal de tio Maximino era tão misterioso, tão cheio de gênios alados e estranhos ruídos zunindo no ar... [...] O quintal do tio Ihe era vedado. Vedado não por seu Gomes ou por qualquer ordem expressa do diretor, mas por ele mesmo. Já que não tinha coragem de visitar tio Maximino, também não pularia o muro, nao furtaria de suas frutas, era o seu código de honra que ninguém ousaria obrigá-lo a quebrar. (DOURADO, 1999c, p. 35)

João vai formando, fragmentariamente, nas lembranças, o retrato do tio pelas próprias observações e pelas histórias de vovó Naninha. Suas iluminações vão se misturando com o negrume da morte pressentida.

João às vezes subia na caixa d'água e lá de cima ficava vendo o mar verde do quintal de tio Maximino. As massas enormes das velhas 
mangueiras, as jaqueiras carregadas, as jabuticabeiras floridas cujo cheiro de longe ele sentia na memória, os cajueiros esparramados, aquela variedade de verdes do quintal de tio Maximino. Mais longe, por detrás da massa verde, aparecia o telhado do casarão, negro de chuva, verde de limo nas beiradas. Ouvia os últimos passarinhos no fim da tarde, o chiado metálico das cigarras disparadas, os pios e ruídos mais estranhos vindo na boca da noite que devorava o verde viçoso e o verde velho empoeirado, e tudo era negrume nos domínios de tio Maximino Filgueiras, derradeiro piaga. (DOURADO, 1999c, p. 36-37)

Nesse jogo de realidade e imaginação, de proximidade e distância, João vê, revê e, sobretudo, transvê a figura de tio Maximino.

\begin{abstract}
Uma vez viu o tio aparecer ao quintal, só podia ser ele. A cabeça branca, carneirinho-carneirão, magro e comprido. Devia ser velhíssimo, muito mais velho do que vovó Naninha, que já era bem idosa. E desempenado, enorme. Maximino desde pequeno sempre foi um varapau, dizia vovó Naninha quando em dia de lembrar e contar casos da família. [...] Agora tio Maximino estava juntinho dele, João podia vê-lo sem que o velho desse conta. Tinha uns ares de vovó Naninha, parecia muito com ela, apesar de que ela não era assim tão magra e comprida. [...] Tão pertinho que João, se quisesse, ouviria os seus muxoxos, discutindo com alguém num passado distante, quem sabe vovô Tomé? (DOURADO, 1999c, p. 37-38)
\end{abstract}

Tio Maximino, assim como Teresinha Virado, apresenta-se, simultaneamente, como mito e realidade aos olhos sensíveis do menino. $\mathrm{Na}$ narrativa autraniana, o perspectivismo do personagem-refletor-metáfora João mostra que o mistério do homem e do mundo dionisiacamente remete ao mistério do próprio tempo e da memória. Narra-se rememorando a origem do ser e a indeterminação do tempo, e não simplesmente a causalidade dos fatos.

Aquele tio Maximino era um mistério. Tio Zózimo também era um mistério, mas tio Zózimo era muito pior, João o conhecia. Tio Maximino era um mistério que ia continuar sendo mistério a vida toda. Tio Maximino era mais uma sombra vindo do fundo da noite, da memória de vovó Naninha, de uma antiguidade bíblica. Tio Maximino era um fantasma andando macio com seus chinelos de liga num casarão vazio.

Do negrume da memória, do poço sem fundo do tempo (João às vezes não sabia se tio Maximino existia mesmo, se ele não estava no lugar de um outro tio Maximino que existira antes e cuja vida em história nas longas noites ele estava vivendo, enfim uma figura e uma força que tinham existido antes de todos os tempos), dos sigilos noturnos, das conversas nebulosas entre vovô Tomé e vovó Naninha, mamãe e tia Margarida, aos poucos ia brotando a figura esguia e fugidia, furiosa e terrível às vezes, mansa e doce, daquele tio Maximino. João tinha a impressão de que, nas histórias que vovó Naninha contava, alguém estava sempre no lugar de alguém, os passos se perdiam no sem fim dos tempos. 
Desde sempre João ficou sabendo que tio Maximino era um dos muitos assuntos proibidos na presença de vovó Naninha e vovô Tomé. (DOURADO, 1999c, p. 40-41)

Assim como o narrador personativo se despersonaliza e representa a voz do menino tentando descobrir os segredos de vovó Naninha: "Será que ela desencavava os fantasmas da sua memória? Onde é que andava o pensamento de vovó Naninha naquelas horas?" (DOURADO, 1999c, p. 41), também assume a voz de vovó Naninha nas suas lembranças da infância com o "outro" irmão Maximino. O refletor João percebe a alteridade do ser humano em sua existência temporal. E o leitor também percebe a convivência das vozes no tempo e no espaço da escrita do livro e da memória de João.

Às vezes provocada por João, ela falava. E então ele via que vovó
Naninha gostava de falar do irmão. Não do tio Maximino de agora
(há mais de vinte anos a gente não se vê), ou de antes, quando vovô
Tomé e tio Maximino brigaram, mas de tio Maximino quando ela e ele
eram pequenos numa fazenda distante no espaço e no tempo que
nem mais talvez existisse. E os dois, Naninha e Maximino, iam brincar
com seixos rolados e brilhantes de tão lisinhos de um rio que passava
na fazenda do pai deles dois. (DOURADO, 1999c, p. 41 )

Nesse perspectivismo narrativo em que o olhar (do narrador e dos refletores João e vovó Naninha) se misturam, o leitor transita de uma consciência à outra, de um nível de enunciação a outro, transpondo as fronteiras lógicas do tempo, do espaço e da subjetividade. Como não perceber que vovó Naninha assume a instância da narração em primeira pessoa, desdobra-se e vai recordando liricamente a infância e o ser perdidos nos instantes pretéritos e recuperados no momento presente?

Maximino era muito bom pra mim, sempre fomos muito chegados e amigos, apesar de que ele era bem mais velho do que eu. Ele é que subia nas grimpas das árvores, caçava ninhos de pássaros ainda com os ovinhos inteiros. Põe lá outra vez, eu dizia com remorso pensando como é que ia ser quando a mãe passarinha voltasse e não achasse mais a sua ninhada. Maximino ia pôr de novo o ninho no mesmo galho, mas pelos meus olhos ele via que eu estava gostando por demais daquele ninho, dizia fica com ele, boba, passarinho não é gente, não via ligar nem um pouquinho, e então eu ficava com aquela boniteza de prenda que Maximino tinha me dado. (DOURADO, 1999c, p. 42) 
Assim, a voz e a visão narrativas vão se alternando e se sobrepondo do narrador personativo aos refletores João e vovó Naninha, que, por sua vez, evoca o ponto de vista do irmão Maximino, como vimos acima. E, então, a partir desta história encaixada de vovó Naninha, vamos percebendo, junto com o refletor João, que, na narrativa mito-poética, personativa e dramática de Autran Dourado, somos um e muitos simultaneamente na memória originária do ser.

Eram assim meio bobas as histórias que vovó Naninha gostava de contar de seu irmão. Mas João achava uma graça, um prazer infinito naquelas histórias. Porque, embora distantes e perdidas num passado remoto, aquelas mesmas histórias podiam ter sido com ele e outra menina. E João, sem perceber, ia descobrindo que as coisas e as pessoas se encadeavam numa ciranda sem fim. (DOURADO, 1999c, p. 42)

Infância e velhice, pretérito e presente, eu e outro eu, enunciação e enunciado, ser e não-ser, narrativa e experiência. Tudo junto, indistinto, mergulhando os refletores e os leitores nas águas correntes, originárias e arquetípicas de nosso "senso comum", de nossa existência telúrica, de nosso sentir dinâmico comunitário. Na verdade da experiência, narrativa e vivida, na técnica autraniana da falsa terceira pessoa ou no discurso indireto livre, assim como nos monólogos interiores indiretos (de João) e diretos (de vovó Naninha), as vozes $e$ as visões entretêm-se como nos versos do poema "Autopsicografia", de Fernando Pessoa:

E assim, nas calhas de roda

Gira, a entreter a razão,

Esse comboio de corda

Que se chama coração.

(PESSOA, 1986, p. 98-99)

Enquanto a cidade vive a agonia e a morte de tio Maximino presente, o refletor-metáfora João vai bordando o retrato pretérito dele a partir dos fiapos ou fragmentos das histórias de vovó Naninha. Mas, se o "eu é um outro" (Rimbaud), João é também o ouvinte/autor/leitor. A visão e a voz, o retrato e a narrativa, o emissor e a audiência interferem-se. 
João não conseguia visualizar direito aquela figura, mas mesmo assim foi se acostumando com ela, já íntimo, e era como se ele o tivesse conhecido há muitos e muitos anos e agora não se lembrava mais como era a sua cara. (DOURADO, 1999c, p. 42)

Íntimo e distante, conhecido e desconhecido, eterno ("há muitos e muitos anos") e efêmero ("agora não se lembrava mais..."), o retrato de tio Maximino se configura e se desfigura na imaginação do menino, como no retrato de Teresinha Virado, no primeiro bloco narrativo. Autran Dourado repete o mesmo e duplo procedimento que entretém o prazer e a dor, a imaginação e a realidade do refletor João acerca das pessoas, dos tempos e dos lugares.

João descobre a verdade, escondida há muito tempo, nos diálogos desinteressados (socrático-platônicos?) com vovó Naninha. Não uma verdade certa e totalmente iluminada, mas indefinida em suas formas.

\begin{abstract}
Mesmo assim, através de imprecisões e recuos, de meias-tintas e nebulosas, João ficou sabendo que antes dele nascer, há mais de vinte anos, tio Maximino e vovô Tomé tinham quase se matado por causa de uma questão de terra, da herança que tinha ficado com a morte do pai de vovó Naninha. Deste, até o nome o tempo tinha engolido. (DOURADO, 1999c, p. 43)
\end{abstract}

Autran Dourado não se restringe a narrar as causas, os fatos e as ações da briga entre tio Maximino e vovô Tomé, mas, sim, a dramatizar os efeitos (os sofrimentos) desse acontecimento na vida e na consciência de vovó Naninha, "dividida entre o seu dever de mulher e o sentimento de irmã" (DOURADO, 1999c, p. 43), e do neto-refletor João. O saber do passado não elimina a dor do presente de ninguém.

De toda essa conversa ficou a impressão desagradável de que vovô não era um homem assim tão direito como ele pensava, como dava a parecer. E como essa descoberta lhe apertasse o coração, João fez tudo por esquecer, nunca mais quis saber quem é que estava com a razão. (DOURADO, 1999c, p. 43)

A morte do ser, que continua atuando diversamente (alegria e tristeza) desde o passado, nas vidas presentes de vovó Naninha, de vovô Tomé e de João, e não simplesmente a morte física e próxima de tio Maximino, eis o tema 
que se modula não só em Nas Vascas da Morte como nos sete blocos narrativos de O Risco do Bordado.

Percebe-se o drama de vovó Naninha, guardado há anos, ao pedir que o neto, estando de partida pela primeira vez para o internato em São Mateus, visite o tio Maximino e leve lembranças para ele.

Então vovó Naninha puxou o menino para junto da janela e teve coragem de dizer o que há muito estava para lhe pedir. Você podendo, João, um dia vai e procura Maximino, ele é vizinho do colégio, eu sei, me disseram. Diga para ele como eu estou, que penso sempre nele, que mando muitas lembranças. Ele é rancoroso mas no fundo é boa alma, gostava muito de mim. É capaz dele já ter até se esquecido, afinal faz tanto tempo desde que... (DOURADO, 1999c, p. 44)

E vovô Tomé, ao ouvir estas palavras, explode em fúria revelando também sua dor, inversa à de vovó Naninha.

E voltando-se para João, vovô Tomé disse, você não vai procurar aquele miserável de jeito nenhum! Aquilo é um unha-de-fome, vai pro inferno que nem a mãe de São Pedro! [...] E depois, tem mais - ele é meu inimigo, você está proibido de pisar lá! (DOURADO, 1999c, p. 44)

Mas, mesmo prometendo à vovó Naninha, João não foi visitar o tio Maximino, não se sabe se por medo de vovô Tomé ou outro motivo. Assim ficamos sabendo quando, nas férias de julho, voltou do colégio para Duas Pontes. Importante é verificar que João, em suas memórias, sofre os efeitos dos acontecimentos participando de duas dores (da avó e do avô). Entre o desejo e a interdição, João vive a agonia e a morte de todos. Mais uma vez, o poema "Autopsicografia", de Fernando Pessoa, é elucidativo:

E os que lêem o que escreve, $\mathrm{Na}$ dor lida sentem bem, Não as duas que ele teve Mas só a que eles não têm.

(PESSOA, 1986, p. 98-99)

João sente a dor que não tem, que brota do que ouviu/leu a partir das histórias de vovó Naninha. E ainda o mesmo poeta Fernando Pessoa nos diz: 
Temos, todos que vivemos,

Uma vida que é vivida

E outra vida que é pensada,

E a única vida que temos

É essa que é dividida

Entre a verdadeira e a errada.

Qual porém é verdadeira

e qual errada, ninguém

Nos saberá explicar;

E vivemos de maneira

Que a vida que a gente tem

É a que tem que pensar.

(PESSOA, 1986, p. 106-107)

Entre o pensar e o sentir, a vida não se separa da morte, a imaginação não se distingue da realidade, e um eu não se dissocia de outro eu. A vida que brota do reino da morte, das sombras do passado e da dor profunda, eis o risco do bordado que se oculta e se desoculta envolvendo cada um e todos ao mesmo tempo.

Nas idas e voltas de Duas Pontes a São Mateus, João viaja agora, física e animicamente, espacial e temporalmente, nas dores de vovó Naninha, vovô Tomé e tio Maximino. No colégio interno de São Mateus, à noite, na sala de estudo, entre o velar e o desvelar da leitura, inicia-se epifanicamente outra viagem:

De repente João sentiu um susto no corpo, acordou da sonolência boa em que começava a se afundar cabeceando. Tentou firmar a atenção no livro, as letras baralhavam. Inútil, desde o começo da noite era assim. Não conseguia ler, o pensamento voava para as bandas do quintal de tio Maximino. (DOURADO, 1999c, p. 45)

Nos monólogos narrados, o refletor João pula da realidade para a imaginação, do presente para o futuro, do colégio para o quarto de tio Maximino.

Esquecido do livro, já divagava. Tio Maximino morrendo, ele chegava no quarto. Abriam caminho para ele passar. É o neto de Naninha, sussurravam. Ajoelhava-se diante do leito do tio, beijava-lhe a mão caída. A morte do justo, a gravura que vovó guardava dentro do livro de reza. Do fundo da sua agonia, tio Maximino dava um último olhar para ele. Lembrança pra Naninha, minha querida irmã - o velho 
querendo dizer. João completaria o recado, bordaria a frase que o tio tinha tentado dizer. Agora sabia muitas palavras, era bamba em sinônimo. Vovó Naninha havia de gostar. De volta do quarto de tio Maximino, ouvia os comentários. A cabeça baixa, modesto, sério. Foi este rapazinho que falou com ele pela última vez. Ele levava o recado da morte. (DOURADO, 1999c, p. 46)

$\mathrm{Na}$ imaginação, João escreve outra história, finge ou modela o que tio Maximino não disse, borda no vazio do silêncio a possibilidade da palavra, simula os comentários de uma audiência e a fama que vai ganhar por seu último gesto. Nasce um poeta, um artista? O leitor pressente a ironia do narrador personativo diante da imaginação fértil do refletor João. Afinal, qual dos dois é o fingidor? Eis a duplicidade enigmática de O Risco do Bordado.

O poeta é um fingidor

Finge tão completamente

Que chega a fingir que é dor

A dor que deveras sente.

(PESSOA, 1986, p. 98-99)

Voltando à realidade, na sala de estudos do colégio, João recebe de seu Gomes, o chefe de disciplina, a notícia acerca do estado de seu tio Maximino e de que estavam à sua espera. O que mais o deixa impressionado, porém, são as palavras esdrúxulas que seu Gomes usava.

Meu filho, foi ele dizendo pausado, seu tio não passa desta noite,
mandaram avisar. Está nas vascas da morte. Seu Gomes e as
palavras difíceis, era muito precioso. [...] Cada palavra que parecia
até nome feio, de tão esdrúxula. Daquela gostou. Vascas, vascas. [...]
Coitado de tio Maximino, navegava nas águas do não, nas vascas da
morte. (DOURADO, 1999c, p. 47 )

Mas João finge estar triste, não se importando com a notícia e sim com as palavras de seu Gomes. Prepara-se, então, para ir à casa do tio.

João abaixou a cabeça, voltou para a carteira a fim de juntar as suas coisas. Fazia a cara mais triste do mundo, dava boa impressão nos meninos. Era sério e compenetrado. Mesmo fingindo uma lágrima não tinha importância, o tio nas vascas da morte. (DOURADO, 1999c, p. 48)

Começa a imaginar o que dirá depois à vovó Naninha: 
Tiveram a delicadeza de mandar me avisar que tio Maximino estava nas vascas da morte, diria depois a vovó Naninha. Convinha aumentar um ponto? Dizer por exemplo que tinha ido lá antes mas que não tinha se avistado com tio Maximino, ele estava muito mal, vários dias agonizante? Depois ia ver, dependendo da hora, da cara de vovó Naninha. De qualquer maneira ela ia ficar muito satisfeita com ele. (DOURADO, 1999c, p. 49)

$\mathrm{Na}$ casa do tio, João se sente perdido e desconhecido, percorre os ambientes repletos de visitas, sente que tudo tem um "ar de velório" e já se arrependia de ter vindo. De novo pronuncia a palavra que aprendeu com seu Gomes e finge compaixão.

Agora ele vai, seu Maximino passa, disse-lhe um homem a seu lado. Passa pra onde? João confirmou muito sério com a cabeça, fez que limpou uma lágrima no canto do olho, tinha de assumir a sua família. Nas vascas da morte. Passava pra onde? Primeiro seu Gomes, agora aquele desconhecido. A morte ensina muitas coisas, ele aprendia. (DOURADO, 1999c, p. 51)

Conhece, então, seu Durval, genro de tio Maximino, que foi quem mandou avisá-lo da situação e chamá-lo no colégio, e sua mulher Adelina, filha de Maximino, sua prima, portanto. Esta lhe recebe bem e até lhe oferece uma xícara de café com leite e um prato de broinhas de fubá. João finge estar sem fome: "Bobagem, disse ela, não faça cerimônia. Esteja a gosto, afinal é da família, veio sofrer com a gente". (DOURADO, 1999c, p. 52)

Ao ser indagado sobre os parentes em Duas Pontes, João finge de novo uma história.

Querem saber notícias, vovó Naninha manda muitas lembranças. Prima Adelina tentou sorrir agradecida, saiu sorriso sem graça e triste, enfiava-Ihe um punhado de broinhas nos bolsos do uniforme. Não precisa, disse ele querendo. Vovó está sempre perguntando por tio Maximino, ontem mesmo recebi carta dela. Mentir assim, pro bem dos outros, dava até gosto. Ele comeu com fome, apesar do cuidado para não parecer esganação. (DOURADO, 1999c, p. 52-53)

Após alguns instantes, nova aflição, e João estava dentro do quarto de tio Maximino. Suas impressões do momento, do recinto e do tio logo se manifestam. Sofre, assim, o sentimento de agonia e morte do tio. O que antes era apenas imaginado por João desvela-se agora em toda a sua materialidade. 
A narrativa dramática e mito-poética de Autran Dourado apresenta, epifânica e dionisiacamente, o ritual da morte pelos olhos do refletor.

Súbito o tumulto, vieram correndo chamar Adelina, seu Maximino agora estava mesmo morrendo. [...]

A porta do quarto escancarada, o quarto assim de gente. A reza na sala cessara. O cheiro pesado e oleoso: suor, mijo, remédio, coisa pior. [...]

Só então João viu tio Maximino. Meu Deus, como ele era comprido e magro! Muito mais magro e comprido do que podia imaginar vendo o velho na horta com a sua espingarda mirando as grimpas. Tão comprido que mal cabia na cama. [...] A cara escaveirada, a barba de dois dias. Os olhos de uma fundura sem brilho, estatelados, esgazeados. O velho não podia estar vendo mais ninguém, nada, nas vascas da morte, já meio no além da vida. [...]

João mal podia respirar, os olhos grudados no velho. Suava frio. [...] Ele não aguentaria mais nem um minuto, a coisa súbito acontecesse. (DOURADO, 1999c, p. 53-54)

O refletor João mais uma vez nos apresenta a experiência da morte, o saber pelo sofrer, como no primeiro bloco narrativo Viagem à Casa da Ponte, os momentos de aflição e terror, o trágico como ser da própria realidade. Enfim, presenciamos novamente o drama de paixão, estático, e não de ação. Os efeitos da morte na vida. A verdade e a prosa epifânicas de $O$ Risco do Bordado envolvem a todos, ao leitor também. $O$ pathos da imagem coloca-nos diante da tensão lúdica do ser e do não-ser.

O velho alongou o pescoço para atingir alguma coisa invisível, feito uma galinha procura alcançar um grelo verde no ar. Os olhos arregalados, ele deu um ronco mais fundo - um galo no gogo, desafinado; repuxou num esgar o canto da boca, uma gosma escorrendo. E de repente parou inteiramente, extasiado. A boca aberta, o peito murcho, os olhos estarrecidos no meio da última visão. Tudo era silêncio e paradeza no corpo do velho, laguna.

João quis se afastar, não podia, cercado. Todos agora suspiravam aliviados, como que voltavam a respirar; de novo à tona, voltavam a falar. E era um vozeio, uns gritos de mulheres se abraçando, chorando e lastimando.

Procuraram afastar as mulheres, começaria então o longo preparo do morto. (DOURADO, 1999c, p. 55)

O ritual da morte, o rito de passagem, João novamente percorre os labirintos da alma, experimenta o abismo da existência: "Esquecido num canto, mal respirando, branco de espanto, João olhava interessado a liturgia nova para ele." (DOURADO, 1999c, p. 55) 
"Espantado e interessado", sentimentos contrários, eis o trágico. importante ressaltar também a recorrência aqui da palavra "liturgia", que já tinha aparecido no primeiro bloco narrativo, Viagem à Casa da Ponte, quando João, estático e extasiado, estava diante das habitantes da Casa da Ponte: "As mulheres todas numa festa fantástica. Ninfas em concílio, liturgia, pura dança." (DOURADO, 1999c, p. 29). Repetição, duplicidade, personagem-metáfora, eterno retorno do mesmo ritual de interação da vida e da morte.

João observa o longo ritual de preparo do morto, a carpintaria lenta do nada, o risco do bordado da vida, a barca dos homens em sua viagem, o trabalho minucioso de construção do labirinto que aprisiona e liberta os vivos e os mortos. A interação do caos e do cosmos, do mito e da ordem. Ao mesmo tempo os leitores se deparam com a escrita da morte também minuciosa e arquitetônica de Autran Dourado, que espalha sinais de auto-referencialidade da própria obra, em seus sete blocos que se espelham enovelando o autor, o leitor, o narrador personativo e o refletor João. O número sete, por exemplo, é outra recorrência especular da micro e macroestrutura de O Risco do Bordado.

\footnotetext{
Os homens eram ativos e diligentes, embora às vezes se atrapalhando nos gestos. A primeira coisa que fizeram foi manter os olhos do morto fechados com uma moeda. É preciso chamar o carapina, disse um. Já está avisado, disse seu Durval. Pede a ele pra fazer o caixão uns sete centímetros mais comprido. Ele sabe, sempre estica. Seu Maximino era enorme de grande, disse o outro, parecia muito prático, entendido no assunto. Como é que ele podia saber que a gente estica exatinho sete centímetros? Sabia, a certeza com que falou não deixava dúvida, nem o médico contestou. (DOURADO, 1999c, p. 55-56)
}

A moeda nos olhos nos sugere a viagem mítica e poética do reino dos vivos ao reino dos mortos, o pagamento ao barqueiro Caronte. O carapina (carpinteiro) constroi a barca (o caixão) para a viagem. A barca dos homens, a obra do artista, o rito da morte. Como o autor, o narrador personativo e o refletor João, estamos todos na mesma viagem, nas vascas da morte, no drama de paixão. Vasca é a grande convulsão, o estertor, a respiração louca e crepitante dos moribundos. A narrativa mítica de Autran Dourado nos inicia no ritual e nos embarca na longa viagem da vida e da morte. 
O trabalho dos homens com o morto é acompanhado pelo refletor João num misto de aflição e terror até que, finalmente, consegue fugir da casa em direção ao colégio.

\begin{abstract}
João foi se esgueirando devagarzinho em direção à porta. A mão tentou girar a maçaneta leitosa, escorregava, ele suando muito. Trêmulo, aflito, finalmente conseguiu abrir a porta e escapulir. Passou correndo pela sala de visitas, ninguém reparou no menino de uniforme.

$\mathrm{Na}$ rua suspirou aliviado, só agora parecia respirar. Da casa até o colégio eram bem uns cinquenta metros. Mas ele estava suando muito, um suor frio escorria pela testa, pelo pescoço. Encostou-se no muro, firmou a cabeça com as mãos, de uma golfada botou para fora o leite azedo, as broinhas mal mastigadas.

Ao se sentir melhor, escutou passos vindos na sua direção. Estão me seguindo, disse ele e saiu numa corrida desabalada. Corre que lá vem gente, gritava mudo para alcançar mais depressa o portão do colégio. Botando a alma pela boca, chegou. (DOURADO, 1999c, p. 57)
\end{abstract}

Da casa de tio Maximino ao colégio, essa cena repete a mesma corrida, fuga e movimentação desesperada do bloco anterior, quando João voltou da Casa da Ponte para a sua própria casa. A narrativa autraniana trabalha, assim, com a estrutura paradigmática dos eventos e dos sentimentos, arquitetonicamente construída em sua duplicidade e recorrência. Neste movimento lúdico de ida e volta, o refletor, o leitor e a obra repetem o mesmo drama de paixão rigorosa e diversamente encenado. Ilusão achar que, na narrativa autraniana, ocorre a eliminação ou catarse das emoções de aflição e terror, conforme a proposta da poética aristotélica acerca do gênero dramático, pois elas sempre retornam a cada bloco narrativo.

Artista consciente do seu ofício, conforme se comprova em seus ensaios metacríticos e poético-pensantes, presentes em Uma Poética de Romance: Matéria de Carpintaria (2000a), Autran Dourado segue os passos de Edgar Allan Poe e Gustave Flaubert, Paul Valéry e João Cabral de Melo Neto acerca da "habilidade construtiva", ou seja, da construção rigorosa e vigorosa da obra de arte da linguagem, que requer paciência, concentração e atenção.

Essa habilidade se baseia, sem dúvida, em grande parte, na capacidade de análise, que habilita o artista a ter uma visão completa do maquinismo dos efeitos propostos e assim trabalhá-lo e regulá-lo à vontade. (POE, Marginália, apud DOURADO, 2000a, p. 125) 
A recorrência de temas e motivos confirma a concepção autraniana da obra de arte como "maquinismo dos efeitos" (Poe).

Nada me agrada mais do que a concepção do poema e da narrativa como máquinas: o que exigem de precisão para produzir seus efeitos. Se pudesse escolher uma divisa, esta seria: precisão e mistério. Fico na dúvida sobre a autoria do dístico: Flaubert ou Poe. (DOURADO, 2000a, p. 126)

O artista moderno como poeta, criador, ser divino, inventor, tradutor, decifrador do ser, da narrativa, do mundo. Hermeneuta, mediador do sentido que se vela enquanto se desvela no tecido da obra e da existência.

Que é o poeta senão um fazedor constante de metáforas, um descobridor de analogias? Aquele que lê na natureza e no homem os signos mais escondidos. (DOURADO, 2000a, p. 127)

O artista como deus de seu mundo, invisível, mas pressentido, em todos os blocos narrativos, nas recorrências e duplicidades. Arquiteto, engenheiro e carapina de seu labirinto, de sua "máquina de comover" (Le Corbusier), e obra. O artista divino lê brincando "o significado subjacente do tapete hieroglífico que é o pêlo de uma onça - não são manchas, são signos." (DOURADO, 2000a, p. 127).

Pensar na concepção hermética do universo como um trançado, um risco a ser decifrado, um bordado a ser lido. "Deus é que sabe por inteiro o risco do bordado", dizem os mineiros, pelo menos um deles você, Autran. (DOURADO, 2000a, p. 127)

No texto "Poética pré-aristotélica", presente em Uma Poética de Romance: Matéria de Carpintaria (2000a), Autran Dourado concebe lucidamente o poeta como mestre, artesão e senhor do seu ofício (instrumento, técnica), e não como invocador das musas ou ser possuído da poesia. Na linha dos antigos pensadores originários (Parmênides, Heráclito) e dos poetas trágicos gregos (Ésquilo, Sófocles e Eurípides), assim como dos modernos poetas (Poe, Baudelaire, Mallarmé, Valéry), Autran Dourado alia poesia e reflexão crítica, sentimento e razão. 
A concepção moderna de ideia súbita, a que nos interessa. Consciente e inconsciente. Psicologia, psicanálise - Freud, Jung, Lacan, Bachelard. Ideia súbita (inconsciente) trabalhada lucidamente, com método, as "virtudes morais" [paciência, concentração, atenção] de que falava Poe. Metáfora do iceberg - a parte submersa e a parte visível. Fugir da palavra inspiração. O mito inseminador, lúcido e misterioso, o rigor construtivo: Baudelaire, Mallarmé, Valéry e cia. (DOURADO, 2000a, p. 129)

Retornando ao bloco narrativo Nas Vascas da Morte, após a saída aflita e apressada de João da casa fúnebre de tio Maximino, encontramos agora o refletor menino no colégio a escrever uma "carta imaginária para vovó Naninha". Neste episódio, afirma Autran Dourado, no texto "Estilo e lugarcomum" (DOURADO, 2000a, p. 80-91), podemos encontrar uma ars poetica às avessas da escrita de $O$ Risco do Bordado, de seu próprio processo construtivo.

\begin{abstract}
Apesar das horas difíceis de seus últimos dias de vida, tio Maximino teve uma morte feliz, ia dizendo João numa carta imaginária para vovó Naninha, enquanto o professor Tito martelava a sua aula monótona. (DOURADO, 1999c, p. 58)
\end{abstract}

Além da morte de tio Maximino e seus efeitos no refletor João, há também neste bloco "a morte de um certo tipo de linguagem pomposa, enobrecida e retumbante, uma linguagem muito usada no Brasil antes de 22." (DOURADO, 2000a, p. 81)

Nos fluxos de consciência do refletor João, continua Autran Dourado, não há ali apenas uma gozação, sátira ou paródia ao estilo de falar do chefe de disciplina seu Gomes, do professor de português Tito e do diretor do Colégio São Mateus dr. Michelet, mas também uma "poética às avessas de todo o livro." (DOURADO, 2000a, p. 81)

Escolheria as palavras que tinha aprendido recentemente. [...] Escreveria como um doutor, por cima, difícil. Como o dr. Michelet, que falava se reclinando na cadeira, no seu gabinete de diretor. Como seu Gomes gostaria de falar, coitado. [...]

Cercado de toda a família, de mim inclusive, que me incorporei contrito aos pés de sua derradeira hora, João continuava. Vovó Naninha, triste a princípio, ficava mais consolada lendo aquelas palavras. Precisava dar um jeito de encaixar a morte de um justo.

[...]

Cercado de toda a família, num ambiente altamente religioso, de grande unção, titio exalou (como estava craque hoje!) o seu último 
suspiro. Será que último suspiro ficava bem, não era lugar-comum, feito condenava o professor Tito? [...] Lugar-comum ou não, ficava bonito, vovó Naninha não sabia nada dessas regras de escrever, jamais na vida tinha ouvido falar em ênclise e próclise, havia de achar uma boniteza último suspiro.

Sim, usaria a morte do justo. Foi uma verdadeira morte de um justo. Ao exalar o seu último suspiro, tio Maximino voltou brandamente a cabeça para a assistência (assistência ficava bem? não era outra coisa? podia parecer desrespeito), dirigiu o olhar brando pelos presentes, como que se despedindo de todos, pousou-o em mim, na senhora, vovó Naninha, porque ele sabia quem eu era, olhou para a imagem de Nossa Senhora da Conceição sobre a cômoda, fechou os olhos de mansinho e entregou a alma a Deus. (DOURADO, 1999c, p. 58-59)

João recorda os conselhos do professor Tito acerca do estilo e acaba rebaixando-os.

Cuidado com as frases longas demais, por causa da concordância e da regência, dizia o professor. Só os clássicos, só os mestres do vernáculo. [...] Cuidado com os quês, com os verbos auxiliares, com as repetições, procureem uma sinonímia rica. O nosso idioma é um manancial inesgotável. Era uma merda escrever assim. O professor Tito falava bem, apesar de que tinha horas era um pouco rebuscado. (DOURADO, 1999c, p. 60)

Faz o mesmo quando estava diante do diretor do colégio dr. Michelet.

Senhor João Nogueira, começou o diretor, estou a par do ocorrido.
[...] O senhor Maximino Filgueiras, seu pranteado tio, era um vizinho
exemplar, um homem de honra e de bem, de elevadas virtudes, um
cristão autêntico, uma figura à antiga, diria mesmo um varão de
Plutarco.
De repente uma angústia fina, uma ansiedade penetrante começou a
invadi-lo. Via o absurdo da fala do dr. Michelet, aquilo tudo não fazia
o menor sentido. [...]
Queria que ele acabasse logo com aquilo, o mesmo suor frio da
véspera. [...] João ouvia as palavras mas não escutava nada do que
ele dizia. [...] De repente o pescoço do dr. Michelet foi se alongando,
se alongando, parecia que ele procurava atingir um grelo verde no ar,
feito uma galinha. João fechou os olhos porque do nariz do dr.
Michelet saíam dois tufos de algodão, a barba grossa azulada, de
dois dias. Como era possível, se ainda há pouco estava tão bem
escanhoado? (DOURADO, 1999c, p. $60-61$ )

Neste instante de angústia do personagem-refletor-metáfora João, podese perceber como, na mente do menino, as palavras e a fisionomia do dr. Michelet subitamente agonizam e morrem como o próprio tio Maximino. João sofre duplamente o impacto da morte, fisica e linguísticamente. Nessa montagem do vivo e do morto, Autran Dourado enterra de vez o estilo 
"clássico" e pomposo do diretor, e sugere o lugar-comum do estilo "moderno" e repetitivo de O Risco do Bordado.

Assim, o artista aprendiz e futuro escritor João da Fonseca Nogueira finge mais uma vez, mesmo quando procura imitar, nas suas cartas imaginárias, o estilo nobre e sublime do professor Tito e do dr. Michelet. $\mathrm{Na}$ verdade, ele exalta o lugar-comum e zomba daquela maneira acadêmica, clássica, rígida e lógica de composição, quando afirma: "Era uma merda escrever assim." (DOURADO, 1999c, p. 60)

Neste bloco narrativo, Autran Dourtado nos desvela, lúdica, lúcida e metalinguisticamente, a mundividência de sua própria estrutura narrativa dramática, filiada à tradição revolucionária, criadora, dinâmica e nada "clássica" de Gustave Flaubert, e não à tradição meramente realista, racionalista e cartesiana da linguagem. O estilo moderno de Flaubert é o da voz dual, conforme nos ensina o crítico Roy Pascal (1977, p. 98-112), em seu livro The Dual Voice: Free Indirect Speech and its Functioning in the Nineteenth-Century European Novel, ou seja, a dupla mediação narrativa que promove a interação da impessoalidade (ciência) do narrador e da pessoalidade (experiência) do personagem-refletor. Estilo, inclusive, absorvido e radicalizado exemplarmente por Henry James e James Joyce, os outros dois mestres carapinas de Autran Dourado.

$\mathrm{O}$ autor mineiro nos esclarece que vem buscando conscientemente $\mathrm{O}$ lugar-comum literário, não enobrecido, desde Nove Histórias em Grupos de Três [1957], onde o menino João da Fonseca Nogueira já aparece na narrativa "Inventário do Primeiro Dia", A Barca dos Homens [1961], Uma Vida em Segredo [1964], Ópera dos Mortos [1967] até alcançar a sua plenitude em $O$ Risco do Bordado [1970], que é um romance de formação e educação "sentimental e trágica".

No segundo bloco, Nas Vascas da Morte, de O Risco do Bordado, o que faço indiretamente é um elogio do lugar-comum, do lugar-comum chapado, literário. Como era literário aquele menino! É uma defesa dos clichês, que o menino-futuro-escritor, ciliciado e silenciado pela velha estilística, faz na sua "educação sentimental", na sua "história 
de formação", no seu "retrato do artista quando jovem". Um menino tateando no escuro os dolorosos passos da "arte de escrever". (DOURADO, 2000a, p. 89)

Numa alusão aos filmes (comédias) mudos de Carlitos e ao poema de Carlos Drummond de Andrade ("Canto ao Homem do Povo Charlie Chaplin") (Cf. ANDRADE, 1969, p. 147-153), Autran Dourado reafirma a sua defesa do lugar-comum, do clichê e da mímica, ou seja, da visão narrativa poética e dramática, trágica e patética do homem e do mundo: "Patético, lugar-comum, mímica." (DOURADO, 2000a, p. 91)

Na narrativa dramática de $O$ Risco do Bordado, o narrador personativo e o personagem-refletor-metáfora João realizam a mimesis poética da silenciosa palavra do sentido ou verdade que se desvela enquanto se vela no tempo. Afinal, o que é o personagem-refletor senão a metáfora, mímica ou encenação dramática da indistinção do corpo e da alma, do silêncio e da palavra? O personagem-metáfora é o movimento lúdico do próprio corpo, a imagem poética do homem e do mundo.

No texto "Personagem como metáfora", presente em Uma Poética de Romance: Matéria de Carpintaria (2000a, p. 218-230), Autran Dourado retoma, de certa forma, essa concepção do patético, do lugar-comum e da mímica presente em seus romances, associando-a, sobretudo, às reflexões de Giambattista Vico, Gustave Flaubert e Gaston Bachelard, entre outros, acerca da imaginação material e dinâmica da poesia.

Sim, as imagens de um poema, a visão metafórica da vida. Ah, então
era isto: o personagem tinha a ver era com a história, com a sua
estrutura, com o seu ritmo, e muito pouco com a realidade e a
natureza; o personagem possuía na narrativa a mesma função que a
metáfora na frase. Enfim, o personagem era uma figuração, um tropo
de retórica, numa palavra - linguagem. Se quiserem,
metaforicamente, sintaxe. (DOURADO, 2000a, p. 220)

Com Giambattista Vico, autor de A Ciência Nova [1725], aprendeu não só que "A metáfora é o mito em ponto pequeno", mas também

Que em poesia as imagens são superiores às ideias abstratas. Da mesma maneira que as ideias poéticas são mais belas quando 
aparecem sob forma mais corpórea. Que assim como a filosofia é mais verdadeira quando vai do particular para o geral, o inverso ocorre com a poesia. As metáforas falam mais aos sentidos e à imaginação do que ao intelecto e à razão. Que toda sabedoria poética, como toda sabedoria filosófica, tem como ponto de partida uma metafísica: uma é sentida e imaginada, a outra é pensada e abstraída. (DOURADO, 2000a, p. 220)

Os estudos de Vico sobre Dante e Homero, que traduzem a sua concepção de poesia como produto da eterna infância da mente humana, bem como a sua visão dos três ciclos da História (o divino, o heroico e o humano), que se constituíram numa reversão da estética platônica e aristotélica (Cf. VERENE, 1981), marcaram profundamente a cosmovisão literária de Autran Dourado.

Com Gustave Flaubert, autor de Madame Bovary [1857] e A Educação Sentimental [1870], aprendeu a lição de que a partir dele "o romance passara a pertencer ao domínio da poética" (DOURADO, 2000a, p. 220). A arte narrativa é a dramatização da experiência humana construída com precisão e mistério, razão e paixão, rigor e vigor (Cf. BOLLÈME, 1964).

Já com Gaston Bachelard, autor de A Poética do Espaço [1957], A Poética do Devaneio [1961], O Ar e os Sonhos [1943], A Terra e os Devaneios da Vontade [1948], A Água e os Sonhos [1942] e A Psicanálise do Fogo [1938], entre outras obras, descobriu que o ser e o devir são complementares na imaginação material e dinâmica do novo espírito científico e do novo espírito literário (Cf. SOUZA, 1987, p. 47-93).

\footnotetext{
A faculdade essencial na feitura da metáfora é a imaginação material e dinâmica, que tudo anima. Usando as palavras de Bachelard, "a imaginação material propõe-se a pensar a matéria, a sonhar a matéria, viver na matéria, ou melhor - o que vem a ser o mesmo - a materializar o imaginário". E é o próprio Bachelard que diz que a "fisiologia da imaginação, mais ainda que a sua anatomia, obedece à lei dos quatro elementos". Ao que poderíamos ajuntar: as melhores metáforas são aquelas que se utilizam do ar, da terra, da água e do fogo. (DOURADO, 2000a, p. 223)
}

Então, na concepção autraniana da narrativa, especialmente em 0 Risco do Bordado, o personagem se apresenta como "materialização dinâmica de ideais, intuições e sonhos". 
Como os símbolos, os mitos e os arquétipos, o personagem sendo a versão moderna dos herois míticos e arcaicos. Os que conhecem Jung e Mircea Eliade sabem do que estou falando.

O personagem é símbolo, é imagem em movimento, enfim - metáfora em ação. (DOURADO, 2000a, p. 224)

O personagem como metáfora, símbolo, corpo, nome, substantivo, imagem em movimento, um ser terreno, encarnado no tempo, e não como uma abstração ou idealização metafísica. Nesse sentido, Autran Dourado recordanos o verso do poeta Carlos Drummond de Andrade acerca da origem da palavra ("a essência é o nome"), presente na terceira parte do poema "A palavra e a terra", do livro Lição de Coisas (1962), e a seguir constata: "O personagem é o substantivo que vive na frase através do verbo que the dá movimento." (DOURADO, 2000a, p. 224). Eis o poema "A palavra e a terra", parte III, de Carlos Drummond de Andrade, que espelha a própria estrutura dramática de O Risco do Bordado:

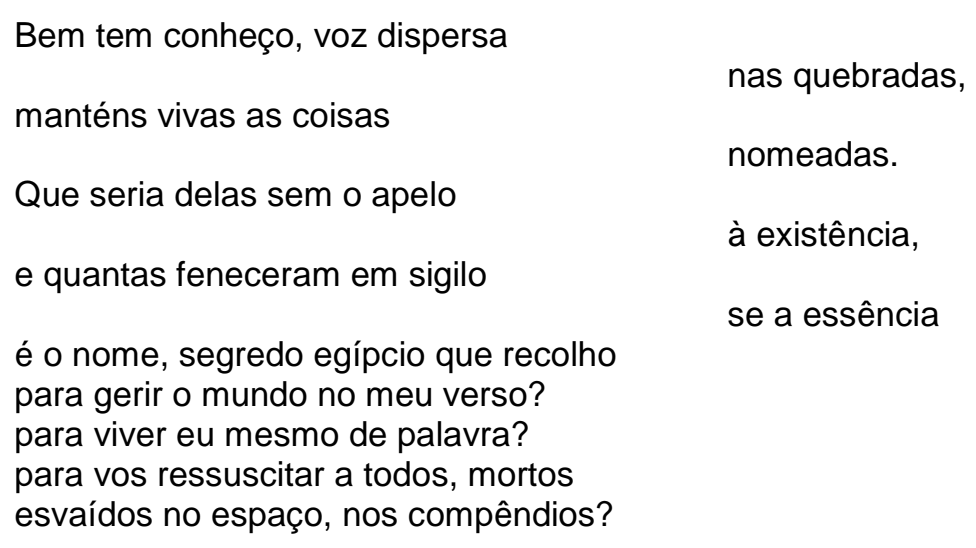

(ANDRADE, 1969, p. 246-247)

O narrador personativo autraniano é quem dramatiza, ou seja, põe em movimento o personagem-refletor-metáfora em seu mundo de experiências encarnadas no tempo. A visão do personagem-refletor João não é simplesmente racional, mas, sobretudo, passional, pois se desvela como a integração de todos os sentidos (visão, audição, olfato, tato e paladar). Assim também é o narrador personativo que estrutura arquitetonicamente a narrativa dramática como interação dos gêneros épico, lírico e dramático. "É sobretudo com o substantivo que se fazem as imagens e metáforas." (DOURADO, 2000a, p. 224-225), diz-nos o escritor mineiro. E a seguir nos relembra, retomando 
ideias do texto "Narrativa em blocos e falsa pessoa", presente na primeira parte de Uma Poética de Romance: Matéria de Carpintaria (2000a, p. 36), numa clara alusão à revolução da lírica moderna de Poe a Mallarmé, passando por Valéry, Drummond e João Cabral, e à revolução da narrativa moderna de Cervantes a Flaubert, passando por Henry James, Marcel Proust e James Joyce: "A ficção é também lição de coisas. [...] A ficção, como a poesia, se faz com palavras e não com ideias" (DOURADO, 2000a, p. 225). Nessa citação há também uma referência ao livro de poesias Lição de coisas, de Carlos Drummond de Andrade, publicado em 1962.

A realidade da ficção de Autran Dourado é a própria ficção da realidade. O escritor não copia, mas inventa a realidade a partir das palavras em movimento, devolve-Ihes o seu sentido dinâmico, que foi petrificado pela visão platônica e cartesiana do mundo (paideia filosófica). O personagem-metáfora é a linguagem em seu sentido originário (paideia poética), que desautomatiza a nossa visão racional e objetiva do mundo. O romance, segundo Autran Dourado, funciona, portanto, como "máquina de promover e dar vida, 'machine à emouvoir"' (DOURADO, 2000a, p. 228). Trata-se de uma referência à frase de Le Corbusier, "Machine à emouvoir" ("Máquina de comover"), utilizada pelo poeta João Cabral de Melo Neto como epígrafe a sua obra $O$ Engenheiro (1940-1945), indicando, assim, o processo lúcido e consciente de construção poética.

A aprendizagem da vida se dá, primordialmente, pelos sentidos, e não pela razão. O drama da narrativa autraniana é o pathei mathos (Ésquilo), o "saber pelo sofrer", eis o retrato do artista, a aprendizagem trágica ou educação sentimental de João da Fonseca Nogueira. O saber pelo sofrer, ou seja, pela experiência dos sentidos, pela metamorfose do ser, e não pela hipertrofia do eu. O Risco do Bordado não define a verdade, não descreve os fatos, mas dramatiza, ou seja, põe em movimento a alteridade qualitativa da existência de João. A obra é uma "máquina de comover" (Le Corbusier), repetem João Cabral e Autran Dourado. E nós repetimos com Martin Heidegger o que dissemos, na primeira parte desta tese, intitulada "Hermenêutica, arte e jogo como escrita da morte": "A arte é, como o pôr-em-obra da verdade, poiesis." 
(HEIDEGGER, 2010, p. 191). A arte funda, inventa um novo ser, um novo homem e um novo mundo. $O$ artista João não é senão metáfora em movimento, em deveniência incessante. O jogo da arte autraniana é o símbolo do mundo. O personagem-refletor João é a metáfora do mundo mito-poético de O Risco do Bordado. É a versão ou imagem moderna do heroi mítico e arcaico, como nos assinalou Autran Dourado.

Não só a obra de arte narrativa do autor mineiro se estrutura em blocos como jogo, mas também o próprio personagem-metáfora-refletor. O modo de ser da obra, do narrador personativo e do personagem-refletor João é o jogo, o movimento lúdico de ir e vir, de desaparecer e aparecer, de distanciar-se e aproximar-se, de morrer e viver incessante do ser no tempo. Tudo é ambíguo, duplo, simétrico e paralelo em O Risco do Bordado. O nome da obra, o nome da cidade, o nome do personagem-refletor, enfim, tudo é duplo no universo autraniano. O Risco do Bordado é a interação do texto e do palimpsesto. Duas Pontes é o caminho de ida e volta. João é a criança divina e humana, o corpo e a alma da própria experiência dos sentidos, o artista que finge (ficcionaliza) a própria realidade, o refletor que espelha simultaneamente o interior e o exterior de si mesmo e do mundo. O narrador personativo é a máscara do autor ou ator que se despersonaliza e dramatiza outro(s) eu(s), o deus invisível de seu próprio mundo, que conhece e desconhece por inteiro o risco do bordado e que se aproxima e se distancia simultaneamente dos seres do seu cosmos. Narrativa mítica, telúrica e simbólica que se estrutura ludicamente na interação do sensível e do inteligível, da paixão e da razão, da vida e da morte, da parte e do todo, de cada mito e da constelação inteira.

Retornando mais uma vez ao bloco narrativo de As Vascas da Morte, atravessamos e experimentamos, física e animicamente, com o refletor João o mundo de sombras, agonia e morte de tio Maximino e do colégio de São Mateus com sua disciplina linguística e estilística rígida, clássica, enobrecida e pomposa, que aprisiona o sentido do ser e das palavras, petrifica a linguagem num mundo idealizante, racional e metafísico, descarnando-os do lugar-comum e patético da concretude vital. Mundo da ordem, apolíneo e opressor, divorciado do corpo dionisíaco deste nosso mundo aqui, telúrico, poético e 
sensível, hipertrofiando o sujeito numa modalidade de ser única, num discurso unívoco e monológico, numa modalidade de escrever, ler e de viver estagnada. Mas, apesar de e a partir dessas mesmas trevas, angústias, águas lodosas e abismos da existência e da escrita, em que mergulhamos com João, chegamos também à outra margem, marcados ainda pelas lembranças de dor e sofrimento que, momentaneamente, nos ilumina e liberta e nos permite imaginar, escrever, respirar, e olhar o texto da vida de outra perspectiva.

Graças à morte do tio, o diretor do colégio, dr. Michelet, concedeu a João um dia de folga para ficar com a família de tio Maximino. Mas, em vez de vestir o luto e mergulhar na razão e dor alheia novamente, preferiu uma roupa colorida, leve e elegante, e saiu a buscar a paixão, a liberdade e a alegria de um passeio pela cidade.

Lavou bem a cara na pia, a angústia aos poucos ia cedendo, ele já se sentia melhor. [...]

Pisando firme e elegante, ganhou a rua. Na rua ele olhava a casa de tio Maximino, o passeio repleto de gente. Vacilou um momento entre a casa do tio e a rua ensolarada, brilhante, sem fim. Entre o dever e a rua não havia escolha. Rente ao muro para não ser visto do colégio, foi descendo a rua na direção oposta à casa do tio. Afinal não conhecia bem nenhuma pessoa da casa, é capaz de que no fundo, no fundo, vovô Tomé é quem tinha razão. De maneira alguma ia voltar lá, não tinha mais graça, tudo se passara há muitos e muitos anos. (DOURADO, 1999c, p. 62)

Zanzando pelo centro, se detém por instantes diante do cinema a imaginar os possíveis prazeres de um filme em cartaz. O leitor acompanha, nesta nova viagem do refletor João, os passos épicos e líricos nas ruas, nas lembranças e nos devaneios.

Olhava os cartazes do cinema, de noite tinha fita de Heddy Lamar, Êxtase. Diziam maravilhas da fita. Ela aparecia peladinha tomano banho de rio. Impróprio para menores, proibido. Seu Gomes nem sabia como é que permitiam passar uma fita daquelas. Nesta terra não há polícia. [...]

Não tinha nada de especial pra fazer, mesmo assim se divertia. Pensou em ir ao Poço da Pedra Lisa, nos domingos costumava ir lá com os meninos. Dava uns mergulhos, umas nadadas. A água friinha, os mosquitos zunindo. O rio limpo, a água clarinha. Seria bom. Mas assim sozinho era perigoso. Podia ser que desse uma cãibra, não tinha ninguém pra salvá-lo. Aí quem ia ter de escrever uma carta para a família era o diretor. Melhor mudar de ideia, espantar a mosca gorda daquela lembrança. Ele não tinha barba, não ia dar tanto 
trabalho. Chega de ontem, gritou espantando a mosca. Melhor outro rumor, cuidar de outro assunto. Não é por falta de assunto que a gente deixa de ficar bestando por aí à toa. (DOURADO, 1999c, p. 6263)

Nota-se, nesse ínterim, que o menino João vai aprendendo a outrar-se, a alterar-se e a não se enclausurar num modalidade existencial de ser, passando de um sentimento trágico a um sentimento cômico e bem humorado da vida. Sabendo conciliar a razão e a sensibilidade. Sentindo-se leve, livre e novo, vai retornando para o colégio. A cena mostra-nos a beleza da prosa epifânica de Autran Dourado. Na imaginação material e dinâmica do menino, do heroi mítico e criança divina, a poética do devaneio, do espaço e do ar promove, como nos ensina Gaston Bachelard, o intercâmbio do eu e do mundo, ensinando-nos a olhar sensivelmente para várias direções e a aprender, epifanicamente, a pedagogia da alegria ascensional do ser que eternamente ressurge do fundo, da fumaça e das cinzas da morte.

Devagar, medindo os passos para se distrair, ora cantarolando ora
assobiando, descia até à estação. Lá embaixo pegou a linha, ia pelo
trilho se equilibrando de braços abertos feito no circo o homem no
trapézio. [...] Chegou, ficou vendo carregarem um trem de café, quis
contar quantos vagões, desistiu, a composição se perdia na curva.
Uma máquina fazendo manobras, apitou. A chaminé soltava um fumo
grosso. Ele ficou vendo o fumo subir no céu muito azul: ia aos poucos
se juntando aos grandes rolos de fumaça que vinha do Armazém
Regulador do Café, a grande queima que o governo tinha mandado
fazer. E olhando a fumaça se dissolver no ar, sentiu-se subitamente
feliz. Afinal de contas tinha ganho um domingo no meio da semana,
uma folga com que absolutamente não contava. (DOURADO, 1999c,
p. 63)

Como a nos lembrar das andanças de Alberto Caeiro, heterônimo e mestre de outro poeta também fingidor Fernando Pessoa, no segundo poema de O Guardador de Rebanhos (1911-1917), o refletor-artista aprendiz João vai descobrindo o mundo e a si mesmo, renovando o olhar e, dionisiacamente, ressurgindo da própria morte.

O meu olhar é nítido como um girassol.

Tenho o costume de andar pelas estradas

Olhando para a direita e para a esquerda,

E de vez em quando olhando para trás...

E o que vejo a cada momento

É aquilo que nunca antes eu tinha visto,

$\mathrm{E}$ eu sei dar por isso muito bem... 
[...]

Sinto-me nascido a cada momento

Para a eterna novidade do mundo...

[...]

O Mundo não se fez para pensarmos nele

(Pensar é estar doente dos olhos)

Mas para olharmos para ele e estarmos de acordo...

Eu não tenho filosofia: tenho sentidos...

Se falo na Natureza não é porque saiba o que ela é, Mas porque a amo, e amo-a por isso.

(PESSOA, 1986, p. 138-139)

Assim, na arquitetura da composição de Nas Vascas da Morte, o narrador personativo vai reduzindo-se ao grau zero em sua impessoalidade e objetividade, ocultando-se para que se ilumine com toda a força sensível o olhar do personagem-refletor João, que, na verdade, como sinestesia simbolista, integra todos os sentidos, manifesta a linguagem corporal em todo o seu dinamismo. Na ciência do narrador-arquiteto da situação dramática, que se despersonaliza para representar outro eu, prepara-se a entrada no palco da vivência telúrica e da experiência epifânica do próprio personagem-metáfora. A educação poética é passional, e não apenas racional. Nas palavras de Autran Dourado, essa técnica de composição visa à autonomia do personagem, que vai adquirindo vida própria e se distanciando da placenta do seu criador. A narrativa personativa não promove, portanto, a subordinação, mas a liberdade do ser, do autor e do leitor, do narrador e do personagem. Nesse sentido, está de acordo com a tradição lúdica e barroca do quixotismo exemplar de Miguel de Cervantes.

Foi essa noção de personagem como metáfora que me permitiu, nos meus romances, a comunicação de uma consciência a outra, sem que os personagens se falem, através de símbolos e imagens que aparecem nos streams ou monólogos interiores das minhas criaturas. Foi ela que me possibilitou fundir numa só duas personagens ou dividir os traços de um personagem em dois. Foi essa concepção de personagem que me permitiu solucionar na consciência de um personagem o problema surgido na consciência de outro. [...] $E$ finalmente, é essa concepção que me permite resolver problemas técnicos de composição como simetria e paralelismo de personagens, perspectiva, aproximação e distanciamento, muitos outros. (DOURADO, 2000a, p. 229-230) 


\subsubsection{Valente Valentina ou Em busca do tempo perdido}

Neste terceiro bloco, que fecha o primeiro grupo (lírico), encontramos uma situação narrativa em primeira pessoa. João agora é o narrador que se desdobra em personagem protagonista e rememora os eventos passados com vovô Tomé, Valente Valentina e a chegada do Circo Milano. O eu narrador do presente (plano da enunciação) se distancia criticamente para representar as experiências líricas do eu narrado do passado (plano do enunciado). Nesse jogo narrativo, intercambiam-se a ciência do narrador e a experiência do personagem, o tempo presente e o tempo passado, o espaço de agora e 0 espaço de outrora. Na caracterização do crítico Franz Karl Stanzel, em seu capítulo "The First-person Novel: Moby-Dick", presente em sua obra Narrative Situations in the Novel: Tom Jones, Moby-Dick, The Ambassadors, Ulysses, a situação narrativa de primeira pessoa implica o desdobramento e a interação do eu narrante e do eu narrado, o reconhecimento da distância temporal e, em decorrência desta, a consciência de uma metamorfose existencial entre o narrador e o protagonista. (STANZEL, 1971, p. 59-91)

João é a metáfora que se duplica em eu da ciência presente e eu da experiência passada. A obra autraniana mais uma vez diversifica 0 perspectivismo narrativo para dramatizar a mútua implicação da razão e da sensibilidade questionando, assim, a visão metafísica de uma verdade ou realidade divorciada da estrutura existencial do ser humano. O conhecimento da realidade é dependente da subjetividade de quem a vivencia. O sentido da realidade do mundo implica a alteridade do sujeito.

Assim, o narrador João nos recorda a metamorfose anímica de vovô Tomé quando se anunciava a chegada do circo.

Uma das coisas de que vovô Tomé sempre gostou foi circo. Mesmo quando a vida o maltratava [...], mesmo no fim da vida, quando foi caindo numa tristeza sem remédio e ficava horas e mais horas resmungando num canto [...], o olhar espetado no teto, [...] se anunciavam circo vovô Tomé sacudia a morrinha, criava alma nova. (DOURADO, 1999c, p. 65) 
Em terceira pessoa, a narrativa inicialmente mostra a distância épica dos eventos narrados no passado para, em seguida, nos apresentar a instância temporal da enunciação crítica de João em primeira pessoa no presente: "Eu acho que não era só por isso, era um lado menino muito bom que havia em vovô Tomé" (DOURADO, 1999c, p. 65). Modulando os tempos verbais ("gostou", "anunciavam", "acho"...), o narrador revela-nos a mudança do sentido do passado ao presente, a distância e a proximidade, a objetividade e a subjetividade envolvidas no processo de recordação. Os efeitos do passado no presente são mais importantes do que os próprios fatos narrados. Conforme nossa tese, o perspectivismo narrativo de O Risco do Bordado modula-se em terceira pessoa ou em primeira pessoa sempre objetivando a representação de um drama de paixão, e não meramente de ação. Encena-se a complexidade e a alteridade do ser no tempo, e não uma definição da existência.

\begin{abstract}
Quando chegava circo em Duas Pontes os olhos de vovô Tomé lumeavam. Ele fingindo que era mais para me levar se animava todo. Não perdia função, tinha um camarote reservado para a família todas as noites. Não era por minha causa, mesmo quando eu não estava em Duas Pontes ele ia [...], mesmo quando eu já não ia mais com a família no camarote e ficava bancando o homem com Zito, Tuim e outros meninos na arquibancada, ele mantinha o camarote. $E$ toda noite lá ia ele com vovó Naninha, tia Margarida antes dela ter se entregue à religião, mamãe e a preta Milurde - quando eu era muito menininho, sá Milurde dizia ir para tomar conta de mim, agora ia por ela mesmo, da família. (DOURADO, 1999c, p. 65-66)
\end{abstract}

A narrativa de primeira pessoa de João permite-nos perceber que, na recordação, falar dos outros (vovô Tomé) corresponde também a falar de si mesmo (João), de suas próprias metamorfoses existenciais e temporais. $\mathrm{O}$ leitor vivencia esses mesmos efeitos no ir e vir do distanciamento e da proximidade dos eventos, já que o narrador (eu de agora) e o protagonista (eu de outrora) são um e o mesmo.

Vovô Tomé vai se apresentando diversamente, muito diferente daquele homem do bloco anterior Nas Vascas da Morte, quando nutria ódio por tio Maximino. Assim também João que, durante a enunciação, vai nos guiando, apontando o caminho como quem nos convida para essa viagem no tempo e no espaço, e faz questão de mostrar que já não é mais o mesmo, que seu eu é outro, até na maneira de falar. 
Mas voltando a vovô Tomé ou melhor - ao circo de cavalinho, que era como ele dizia quando circo chegava na cidade (eu dizia apenas circo, achava circo de cavalinho um pouco antiquado, mais ao jeito de vovô Tomé e vovó Naninha, eu cuidava muito do palavreado, agora no ginásio - isso foi depois; antes, muito menininho, eu falava feito ele, feito vovó, feito a preta Milurde, só não falava que nem o nhô Chico, que era da roça, mocorongo demais), quem primeiro me dava a notícia não era nenhum menino (menino sempre sabe as coisas na frente de todo mundo, menino é que leva-e-traz), mas vovô Tomé.

Circo chegando, vovô Tomé virava outro. (DOURADO, 1999c, p. 6667)

O ritmo da narração autraniana repete o tema da viagem desde 0 primeiro bloco Viagem à Casa da Ponte. Só que agora quem nos conduz, sintática e estilisticamente, no tempo e no espaço, na interioridade e exterioridade do personagem protagonista menino, em suas alegrias e dores, é o narrador João, o outro, que se distancia de si mesmo, para que soframos juntos os impactos de suas experiências na infância e adolescência (eu narrado).

Pode-se dizer que o procedimento do narrador personativo, no primeiro e segundo blocos, ao se despersonalizar para que vivenciássemos o mundo pelo olhar sensível do personagem-refletor João, tem aqui uma correspondência bastante singular. Agora é o próprio João que assume o desempenho dramático do ator que se despersonaliza e nos apresenta a si mesmo na infância, permitindo-nos que também vivenciemos o mundo pelo olhar sensível do personagem-protagonista menino João. Nos outros blocos, a enunciação ia e vinha do narrador anônimo (invisível) ao refletor João (visível). Neste terceiro bloco, ela continua indo e vindo, mas do narrador João (presente) ao protagonista João (passado). No jogo narrativo, o narrador, o personagem-refletor, o personagem-protagonista e o leitor não são apenas jogadores, mas também jogados e co-jogados pelo movimento lúdico da enunciação e do enunciado.

Na visão mítica e dionisíaca da narrativa, a metamorfose ou epifania do ser é o símbolo do mundo de $O$ Risco do Bordado. A imaginação criadora quixotescamente transfigura a realidade. 
O mastro erguido, a lona esticada, vovô Tomé ficava feliz da vida, feito o dono do circo. Aquilo deixava de ser circo, era um navio antigo, vovô Tomé deixava de ser fazendeiro, virava armador de navio, dono de todos os mares. (DOURADO, 1999c, p. 67)

Na enunciação do narrador João, evidente se torna a questão do tempo alterando o sentido. A memória narrativa não comparece como reprodução do que aconteceu, mas como criatividade, indefinição ou invenção do sentido. $O$ passado é retratado literariamente. $O$ tempo do agora transmuta o sentido do tempo do outrora.

\begin{abstract}
Isso foi depois, quando eu lia os livros de aventura e comparava me lembrando dos tempos de quando a gente ia ver armar circo, eu muito menininho ainda; depois, quando comecei a ler os livros da coleção Terramarear no grêmio do Colégio São Mateus, e me lembrava de vovô Tomé, de vovó Naninha, de mamãe, o coração miúdo de saudade. (DOURADO, 1999c, p. 67)
\end{abstract}

Reafirma-se a distância temporal e a metamorfose existencial entre o eu (presente) e o outro eu (passado). A narração rememorativa não nos indica com certeza a idade cronológica do personagem, fazendo-nos sentir que se trata de um tempo mítico ainda produzindo efeitos na atualidade do narrador. João está proustianamente em busca do tempo perdido, recordando e re-descobrindo ("recuperando") não os fatos, mas o sentido da história que vivenciou com vovô Tomé, o circo e Valente Valentina. Significativa é a relação concriativa entre as memórias narrativas em primeira pessoa do artista João e as de Marcel na obra Em Busca do Tempo Perdido, de Marcel Proust. Como nos diz o crítico Hans Robert Jauss, em sua obra Tempo e ricordo nella Recherche di Marcel Proust, há no romance proustiano uma verdadeira dialética entre o eu que recorda e o eu recordado (JAUSS, 2003, p. 113-147). Assim, narrar lembrando é re-compor o fio da memória, o risco do bordado da própria existência, o retrato do eu e do mundo que se perdeu nas brumas do tempo. É re-correr ou re-encaminhar-se nos labirintos da memória do ser. É tirar da morte do passado de si mesmo os fios da própria vida (teia) presente.

Eu tinha então - no tempo da comparação - dezesseis, vamos dizer dezessete anos, não sei ao certo, só fazendo as contas, e não ia mais ao circo com vovô Tomé por causa de Zito e da rapaziada alegre, como foi o caso do Circo Milano, dos irmãos Ramurazzi, don Arcângelo e don Cirino, da Valente Valentina, desta história que 
agora vou lembrando, aos poucos recuperando como um bicho-deseda ou uma aranha vai tirando de si o fio da própria teia... (DOURADO, 1999c, p. 67-68)

A recorrência de estruturas paradigmáticas, morfológicas e sintáticas na obra autraniana denuncia o esforço dramático do narrador de localizar no tempo e temporalizar no espaço a verdade ou sentido que epifanicamente se esconde e se ilumina: "Isso foi depois", "quando", "então", "lá", "agora", "de repente". Nessa viagem mitica e narrativa às origens do tempo e do ser, o narrador-escritor e o leitor vamos percorrendo metafórica e poeticamente os caminhos da linguagem. Diferentemente dos filósofos e cientistas, diz-nos Autran Dourado, no texto "Uma segunda ordem de leitura", presente em Uma Poética do Romance: Matéria de Carpintaria, "os ficcionistas, como os poetas, usam as palavras no seu sentido mais comum [...] o sentido carnal, vamos dizer assim, terreno, cotidiano, comum." (DOURADO, 2000a, p. 45). Nas lembranças do narrador de primeira pessoa, nos fluxos de consciência ou monólogos interiores diretos de João, não encontramos uma visão de mundo racional e metafísica, aérea, platônica (idealidade) ou cartesianamente (subjetividade).

Na paideia poética de Autran Dourado, explicitamente comprovada em seus artigos e ensaios metaficcionais, assim como implicitamente em O Risco do Bordado, nas situações narrativas de terceira e primeira pessoas, que configuram as memórias criativas do menino-escritor e personagem-metáfora João da Fonseca Nogueira, as palavras e as coisas se manifestam lúcida e ludicamente encarnadas no tempo, nas experiências sensíveis da escrita e da vida, diferentemente da paideia dos cientistas e filósofos.

Foram os poetas e prosadores que deram a elas [as palavras] a sua mais alta expressividade e beleza, circunscrevendo-se ao sentido comum, à sua visão terrena das coisas. (DOURADO, 2000a, p. 47)

O narrador João repete as estruturas sintáticas para explicitar a sua aprendizagem irônica e sentimental, ontológica, e não apenas racional e cronológica do mundo. As lembranças poéticas não separam, mas fundem e confundem as pessoas, os espaços e os tempos. 
Bem, de repente, cheguei ao tempo em que eu devia ter uns dezesseis, vamos dizer dezessete anos, e o circo era o Circo Milano. [...] Se me lembro de vovô Tomé quando estou lembrando de circo, de Valentina, é porque vovô Tomé e circo estão tão ligados dentro de mim que não consigo separar as duas coisas. Como aconteceu agora, não sei se me lembrei do Circo Milano e da Valente Valentina porque pensei em vovô Tomé ou se me lembrei de vovô Tomé porque pensei no Circo Milano. (DOURADO, 1999c, p. 68)

Mas as memórias também revelam, paradoxalmente, no presente narrativo, que o eu e o mundo de Duas Pontes/São Mateus, João e vovô Tomé, o menino e o circo/colégio estão separados existencialmente. Difícil não perceber que o eu da enunciação se distancia ironicamente de si mesmo e do passado.

Porque agora eu tinha dezesseis, vamos dizer dezessete anos, estava de férias visitando a família, sabia muitas coisas, começava a empregar palavras difíceis, remedava a sério o professor Tito, o dr. Michelet do Colégio, me achava importantíssimo, era quase um homem, parecia até doutor de anel no dedo. Eu me julgava acima daquelas coisas, não era nenhum menininho para andar feito antigamente de luminária acessa por qualquer circo que chegasse a Duas Pontes, muito menos saía com vovô Tomé para ver a armação do circo, ele agora coitado ia sozinho. (DOURADO, 1999c, p. 68-69)

João agora é outra persona, experimenta outra forma de saber, ser e amar. O mesmo circo que encantava o menino com seus atores e animais agora faz o coração do quase homem desabrochar na aprendizagem de prazer e dor, sobretudo, como veremos mais adiante, com Valente Valentina. de perto, uma de verdade. (DOURADO, 1999c, p. 69-70) 
As memórias revelam que a sua aprendizagem passava do sonho (abstrato) à realidade (concreta), como no caso de Teresinha Virado, no primeiro bloco narrativo. Repete-se, na obra autraniana, o movimento lúdico de transformação da imaginação formal (aérea, racional) em imaginação material e dinâmica (terrena, carnal). Da razão abstraída à sensação material e dinâmica da própria vida: "Era melhor pensar em Teresinha Virado, esta ao menos eu conhecia: antes - de vista, depois da minha ida à Casa da Ponte de vista, de tato, de cheiro." (DOURADO, 1999c, p. 70)

Esse trecho elucida muito bem a cosmovisão ou técnica do perspectivismo narrativo na obra de Autran Dourado, especialmente em $O$ Risco do Bordado. A visão narrativa não é apenas racional, mas, fundamentalmente, passional porque implica a integração simbolista de todos os sentidos (vista, tato, cheiro). A narrativa dramática de Autran Dourado não confirma o divórcio metafísico do saber e do ser, pois representa concriativamente o ditame poético de Ésquilo acerca do pathei mathos ("saber pelo sofrer"), tão bem expresso na tragédia grega Agamêmnon.

Seja nestes três primeiros blocos narrativos, com Teresinha Virado, Tio Maximino e, agora, com Valente Valentina, ou, como veremos, nos quatro próximos blocos, com tio Zózimo, vovô Tomé, tia Margarida e Xambá, a aprendizagem do personagem-metáfora João, o drama de sua vida e de sua escrita, mostra-se sempre como um saber de experiências feito, uma integração do inteligível e sensível. E assim também, em grande escala, manifesta-se a própria estrutura de composição de O Risco do Bordado, que nos transforma em um leitor-metáfora que experimenta simultaneamente a interação da razão e da paixão como drama da linguagem. A forma e o conteúdo da narrativa autraniana são isomórficos, representam o eterno jogo de interpenetração do saber e do sofrer, do escrever e do ler, da literatura e da existência.

João se inicia, simultaneamente, nas artes de viver e de escrever, nos segredos do sentir e da linguagem, nos dilemas da palavra e do silêncio. 
Os reclames que os moleques distribuíam de porta em porta falavam muito no número da Valente Valentina. [...] Valentina, a valente menina do trapézio, do arame, da bicicleta - assim a gente devia fantasiar, quis comentar com Zito mas tive vergonha, certas coisas agora eu não comentava com ninguém, pensava era em escrever uma carta, tanto podia ser para vovó Naninha quando no internato, ou para um amigo invisível a olho nu, igualzinho a mim em tudo, que eu agora cismara de inventar. (DOURADO, 1999c, p. 70-71)

Nesse jogo de fiç̧ão e realidade, no micro e no macrocosmo da obra autraniana, o fingimento poético é a própria modelagem do ser e do escrever. Como nos diz Fernando Pessoa, no poema "Autopsicografia", não só o poeta é um fingidor, mas também o leitor. Na dor escrita ou na dor lida, na vida vivida ou na vida pensada, no eterno jogo da palavra e do sentido:

Gira, a entreter a razão,

Esse comboio de corda

Que se chama coração.

(PESSOA, 1986, p. 98-99)

Na escrita da enunciação narrativa (agora), na experiência concreta do personagem João (outrora), na prosa epifânica da própria obra autraniana, experimentamos a verdade simultânea do ser e do pensar se revelando dramaticamente.

De repente pertinho de mim, ela me olhou bem nos olhos, sorria. Senti um medo, uma vergonha, uma coisa esquisita se passou comigo. Porque eu estava muito interessado nas suas coxas, nos seios apontando durinhos e estofados no maiô prateado. Eu pensava numa porção de coisas, pensava em Teresinha Virado de repente de noite, podia agora juntar as duas. Não contava de jeito nenhum que ela olhasse para mim, eu nunca tinha ficado perto de ninguém assim tão nua, nunca vira ninguém de maiô. Valentina era ruiva, tinha a cara toda pintadinha de sarda coberta de pó-de-arroz, mas talvez por isso mesmo comecei a achar ela linda. [...] Pertinho de mim, eu podia sentir o cheiro de Valentina. (DOURADO, 1999c, p. 73-74)

A trama imagética de efabulação de $O$ Risco do Bordado, feita de duplicação e paralelismo, vai compondo as cenas num movimento lúdico de metáforas e montagens.

Eu começava a criar um novo sonho, um novo mito para o meu consumo diário; só as mulheres vertiginosas da Casa da Ponte (Teresinha Virado no seu roupão vermelho, as chinelinhas cor-derosa) não chegavam. (DOURADO, 1999c, p. 75) 
Autran Dourado nos revela que, desde seu primeiro romance Tempo de Amar [1952], vem trabalhando com o método dramático de composição, em que narrar se conjuga com mostrar, numa referência explícita à arte do romance de Henry James e, implícita, à de Gustave Flaubert e James Joyce. Cada vez mais a arte do romance se aproximava das técnicas de montagem e metáfora do cinema (Cf. HALPERIN, 1974, Novel and Camera, p. 177-188). Conforme nos diz o autor: "O que eu tinha conseguido em Tempo de Amar, a técnica verbal que eu descobri [...], nada mais era do que uma fusão entre o famoso ponto de vista de Henry James e o olho-câmera do cinema." (DOURADO, 2000a, p. 34)

Não só o verbo, mas o substantivo também são trabalhados dinamicamente por Autran Dourado. A gramática da narrativa autraniana se aproxima da gramática da poesia. Assim, as palavras e as coisas revivem a sua origem poética.

O personagem, seu nome e seu corpo. O personagem como imagem ou metáfora. O personagem é substantivo. Lidando com o substantivo e lendo Vico, as suas considerações sobre a poesia, aprendi que as imagens são superiores às ideias abstratas. (DOURADO, 2000a, p. 35)

A narrativa das memórias de João não relata a ação pretérita, mas recorda criativamente o sentido ainda vivo do drama de paixão com Valente Valentina. A gramática da narrativa autraniana/joanina se mobiliza poeticamente para mostrar ao leitor o intercâmbio do sentir e do pensar, do passado e do presente. Daí a importância do verbo e do substantivo na configuração poética da narrativa que recupera a seiva viva das palavras e das coisas. Autran Dourado revela, assim, a sua prórpria concriatividade literária ao elucidar a importância da narrativa dramática de Gustave Flaubert e suas implicações nas obras de Henry James e Marcel Proust. (Cf. JAMES, 2000; PROUST, 1994, A propósito do "Estilo" de Flaubert, p. 65-85) 
alcançar uma aproximação ou afastamento do objeto ou da cena, conforme o caso. Como se fosse uma câmera que vai do long-shot ao close-up ou ao contrário. Aliás, o cinema teve que inventar esses recursos porque não conseguia dizer 0 que 0 romance dizia, narrativamente, com o verbo.

E desde que não há nada de novo sobre a terra, lembremos que Proust dizia que todo o encanto do estilo de Flaubert residia no uso do imperfeito. Uma verdade que só um gênio como Proust, um gênio e artesão como Flaubert, podiam descobrir, se é que não descobriram antes deles. (DOURADO, 2000a, p. 36-37)

\section{E o personagem João, fascinado pelos olhos e cheiro de Valente}

Valentina, vai, nos seus monólogos interiores, desfiando a integração e o desregramento dos seus sentidos. Até mesmo o número do globo da morte perde a importância diante do seu novo interesse. No destaque, o pretérito imperfeito e o gerúndio presentificando a epifania do instante recordado, a manifestação de outra morte.

De repente o globo da morte, todas as sensações fortes que eu esperava, o perigo anunciado, as apostas que eu tinha feito, tudo isso perdia sentido, nada mais interessava. Eu só vivia aqueles olhos afogueados, brilhosos, risonhos, aquela pele pintadinha, o cheiro de hortelã pimenta ainda no nariz, os cabelos-de-fogo esvoaçando no vôo dificílimo do trapézio [...], agora em outro trapézio, na companhia de outros seres alados, impossíveis e vertiginosos da minha vida.

Os olhos catando aqui e ali onde é que agora andava Valentina, o nariz farejando o rastro (dentro e fora de mim), o tato (mais que o tato, adivinhava a presença, a proximidade) no postal dentro do bolso, procurava me lembrar como era mesmo a figura de Valentina no retrato. [...] Meu coração batia surdo não de medo do que podia acontecer agora no globo da morte [...], isso não me importava em nada, mas pela aflição de não encontrar de novo naquela multidão de gente um maiô prateado, um cabelo-de-fogo. (DOURADO, 1999c, p. 76)

A angústia de João logo diminui ao encontrar novamente Valentina.

Repete-se a estrutura sintática e narrativa que parte do real ao sonho.

De repente eu achei Valentina junto dos casacas-de-ferro que duros montavam guarda na porta de saída dos artistas. Ela brincava com um cachorrinho vestido com um corpete de veludo vermelho, jogando uma bola de gomos coloridos para ele abocanhar de pé se equilibrando nas patas traseiras.

Só ela, eu e o cachorrinho parecíamos não dar pelo sensacional espetáculo circense do globo da morte [...] $\mathrm{Na}$ verdade eu estava agora muito pouco interessado na possível morte daqueles homens, queria arrependido estar no camarote de vovô Tomé (dali eu podia ver Valentina mais de perto), queria era que tudo acabasse o mais ligeiro para poder ir para casa e conferir o meu sonho. (DOURADO, 1999c, p. 77) 
No dia seguinte, ainda vivendo seu novo mito, João foi bem cedinho para a porta do circo à procura de Valentina. Ao reencontrá-la, momentaneamente, não reconhece o brilho e o encantamento da noite anterior. Agora o sonho desfaz-se em realidade prosaica. Mas, de repente, retorna de novo.

Ela começou a assobiar a música que a acompanhava no arame,
batia a bola de gomos coloridos no chão. Me lembrei dela no maiô
prateado, agora estava vestida com um vestido amarelo meio
desbotado. Valentina tinha empalidecido, eu achava. Não mais
aquelas cores, aquele brilho de ontem à noite. Feito uma flor na jarra
perde o viço, é capaz de que só de noite, ao som da banda, ao brilho
das cores lustrosas, das carreiras de lâmpadas acesas no picadeiro,
ela vivesse a sua própria vida; de dia apagada, amarelecida.
Mas não, ela sorriu para mim. E todo o brilho, toda a cor, todo o
sonho colorido de ontem parecia renascer. (DOURADO, 1999c, p. 78)

Neste desvelamento e velamento do sentido, João vai conversando com Valentina, que lhe sugere um passeio de bicicleta pela cidade. Ela mesma se dispõe a ir à casa de João e consertar a bicicleta que há tempos ele não usava. Surpreende-se com o gesto: "Nunca tinha visto aquilo na minha vida. Valentina parecia um menino de tão desembaraçada." (DOURADO, 1999c, p. 78). João fica sabendo então que, no circo, Nicola e Gina não são seus pais de verdade: "Eles são meus pais é de fingimento, para efeito artístico. Minha mãe morreu faz tempo, meu pai eu nem conheci" (DOURADO, 1999c, p. 78-79). E que não é italiana como imaginava ser pelo nome, mas brasileira mesmo.

Não foi a única decepção que tive naquele dia. Depois ela me disse que não se chamava Valentina, seu nome era Sueli, um nome enjoadinho, ela mesmo achava. Mas faz favor de continuar me chamando de Valentina, que é como todo mundo me chama. (DOURADO, 1999c, p. 79)

$\mathrm{Na}$ casa de João, a menina desinibida conserta sozinha a bicicleta. Almoçam juntos e, à tarde, vão ao posto encher e consertar os pneus para o passeio: "No fundo eu estava feliz da vida", monologa o personagem João, iniciando uma nova viagem, uma nova aventura do ser.

E passeamos a tarde inteira. Fomos para o campo de futebol, e lá no plano ela me ensinou a fazer uma porção de coisas malucas com a bicicleta. Levei alguns tombos, sujei a roupa e a cara de terra. [...] $\mathrm{E}$ Valentina ria de mim, eu sentia uma onda de prazer me invadir com o 
riso de Valentina. Quem sabe um dia você não entra pro circo? disse ela brincando. Eu ri muito da brincadeira, parece que a gente se conhecia há muitos anos. Aquela tarde foi toda feita de magia e deslumbramento. (DOURADO, 1999c, p. 80)

Viagem mítica, tempo infinito, magia do mundo. Nessas memórias, a elevação logo se torna a queda da alma, a alegria de repente vira tristeza. João vai compreendendo, em sua emoção dramática, que do fundo da felicidade também brota a dor.

E lá se foi assobiando feito saísse do picadeiro. Eu fiquei vendo Valentina desaparecer no fim da rua. Comigo restou a impressão dos seus cabelos vermelhos voando com o vento da bicicleta, um pedaço branco de coxa quando ela saltou despreocupada em cima do selim. Fechei os olhos para guardar melhor, antegozando a noite que se fazia dentro de mim. Meu coração não aguentava tanta beleza, tanta coisa nova num só dia. Meu coração estalava de alegria, estalava de dor. (DOURADO, 1999c, p. 81)

À noite, no circo, João não quis ir e ficar com os amigos, principalmente Zito. Quem foi seu mestre e iniciador no primeiro bloco Viagem à Casa da Ponte ia deixando de ser. Ficou no camarote de vovô Tomé, seu interesse mudava de novo. João se sentia muito importante, agora não pela idade ou pelas palavras difíceis que aprendera no colégio, mas por Valente Valentina.

A minha entrada no circo foi triunfal, eu achava. Via todo mundo me
olhando, via os rapazes me olhando com inveja, via as meninas
despeitadas me olhando com o rabo do olho. Me achava completo,
um homem. Aquelas meninas bobas de Duas Pontes não chegavam
nem aos pés de Valentina. Com certeza a cidade inteira comentava,
todo mundo me viu quando passei sozinho com Valentina em direção
ao campo de futebol. A lente de aumento da minha emoção
engrandecia tudo, me sentia como o trapezista que caminha solitário
para o trapézio para fazer o seu número mais arriscado, todos os
olhos grudados nele, em mim. (DOURADO, 1999c, p. 81-82)

A narrativa de primeira pessoa permite ao leitor conhecer a verdade dos eventos duplamente. Por um lado, a enunciação indica o saber distante do narrador. Por outro, o enunciado nos dá a emoção próxima do personagemprotagonista. Neste intercâmbio do eu narrante e do eu narrado, o leitor experimenta as metamorfoses do sujeito e do mundo, da razão e da paixão. As memórias trazem do fundo da morte (passado) um sentido ou questão para a vida (presente). Pelo olhos do personagem, percebemos a sensibilidade do 
quase homem. Pelos olhos do narrador, a ciência de que o tempo também devora os sentidos e nos mostra a abissalidade do eu e do mundo.

\begin{abstract}
Quando Valentina entrou senti toda a emoção que tinha guardado na véspera para o globo da morte e não pude usar. À luz daquelas cores, da música alegremente esfuziante e ligeirinha que acompanhava a sua entrada no picadeiro, Valentina parecia mais bonita do que nunca, era a coisa mais linda do mundo. O maiô prateado aumentava o brilho e o mistério, Valentina era o que depois nos meus rascunhos eu chamaria exagerado de ninfa encantada da floresta. [...] Eu passei a achar o número de Valentina a coisa mais interessante do Circo Milano. (DOURADO, 1999c, p. 82)
\end{abstract}

No intervalo, para a surpresea de todos, Valentina foi ao camarote de vovô Tomé visitar João, e ainda levou o dono do circo don Arcângelo Ramurazzi. Todos no circo olhavam para João, que se sentia "a pessoa mais importante de Duas Pontes", até os amigos, como Zito e Tuim, que agora o viam como inimigos rancorosos. Mas isso também promove outras reflexões de João acerca de si mesmo e de Valentina.

Aquilo tudo era obra de Valentina, ela me piscou um olho se não me engano; ela era muito mais inteligente e desembaraçada do que eu, menino mocorongo de Duas Pontes. Valentina tão diferente de mim: menina de circo, cada dia num lugar [...], ave sem pouso certo, conheceu uma multidão de gente, é capaz de não se lembrar depois nem mesmo que esteve alguma vez na nossa cidade, se existiu alguma vez alguém chamado João da Fonseca Nogueira, um menino família como tantos outros do mundo, eu triste comparava, apesar de que agora, depois do internato, era bem mais esperto. (DOURADO, 1999c, p. 83-84)

Segundo o narrador João, Valentina era "a pessoa mais viajada do mundo", "a pessoa mais livre do mundo". E, fascinado, o personagem expressa sua admiração:

Que gente tão diferente da minha gente! Como era bom ser de outro país, de outro planeta. Como era bom ser viajado, tio Zózimo é que tinha razão. Aos poucos me acostumava com o desconforto do privilégio, de uma certa maneira já fazia parte do maravilhoso Circo Milano. (DOURADO, 1999c, p. 84)

O narrador nos relembra auto-criticamente que o personagem João também era um fingidor, pois contava aos amigos coisas que não aconteceram ("conforme inventava o desejo malicioso") entre ele e Valentina. Como reação a 
esse nada acontecer, passa a difamar a menina de circo, "filha do mundo, pasto das ruminações de toda gente."

Comecei a mentir porque nada, absolutamente nada acontecia. Ou melhor, acontecia. Acontecia um nada tão cheio de promessas, um nada tão carregado de emoções tensas e delicadas, de promessas e risos e sonhos, que meu coração menino via tudo nas lentes de um telescópio. Como eu não podia dizer aos outros tudo de grandioso que estava acontecendo comigo (se eu abrisse a emoção estaria perdido), porque nada acontecia, passei a inventar as piores coisas. [...] (DOURADO, 1999c, p. 85)

Mas, aos olhos e sentidos do narrador presente, essa mesma constatação do nada ainda promove questões misteriosas. O que acontecia? $\mathrm{O}$ que aconteceu? Mito? Realidade? Nada? Tudo?

Porque nada, absolutamente nada acontecia. Que foi que aconteceu naqueles dias todos que o Circo Milano ficou na nossa cidade? Que foi mesmo que aconteceu naquelas tardes que saíamos juntos a andar de bicicleta? (DOURADO, 1999c, p. 85)

A narrativa mítica e dionisíaca de Autran Dourado vai riscando pacientemente o bordado que alia a imaginação e a realidade, o ser e o nãose, a vida e a morte, o passado e o presente, o saber e o ser. Em mais uma cena de beleza singular, a prosa epifânica prepara o advento de uma nova verdade.

\begin{abstract}
Uma tarde, depois de muito andar, de muito pedalar as nossas aéreas bicicletas, vencidos pelo cansaço, nos deitamos de costas no chão, um ao lado do outro, e ficamos um tempão sem conta olhando as nuvens preguiçosas no céu tinindo de azul fazerem e desfazerem os mais estranhos e caprichosos desenhos, as coisas mais fantásticas que a gente ia inventando de nomear. As nuvens brancas e preguiçosas, eu e Valentina cansados da bicicleta, cansados dos nossos corpos que ainda não tinham se acostumado a viver. (DOURADO, 1999c, p. 85-86)
\end{abstract}

As próprias coisas terrenas e seus nomes já têm uma correspondência com as imagens celestes. O que se movimenta em baixo também se movimenta em cima. As nuvens e os corpos, o céu e a terra poética e miticamente se correspondem na imaginação material e dinâmica de $O$ Risco do Bordado. Nesta obra e neste mundo, o ser é um devir. 
Eu vi para sempre o perfil de Valentina recortado na tarde azulada. Senti um desejo forte demais de passar de leve a mão no seu rosto, acompanhar de levezinho o desenho do nariz fino, dos lábios entreabertos, do queixo levantado. $E$ os meus olhos como que tocaram os seus olhos, a sua pele pintadinha, os seus lábios molhados e quentes. Como que apalpavam os doloridos peitinhos que agora mal existiam porque ela estava deitada, só eram atrevidamente espetados quando ela enfrentava o vento na bicicleta. E o meu nariz dilatado procurava cheirar, em goles que enchiam todo o peito, a respiração cansada e quente de Valentina. (DOURADO, 1999c, p. 86)

$\mathrm{Na}$ transição do pretérito perfeito ("vi”) ao imperfeito ("apalpavam"), vamos com João dramaticamente nos distanciando e aproximando, física e animicamente, de Valentina. No lúcido desregramento dos sentidos (ver, tocar, cheirar), a narrativa autraniana vai, simbolicamente, passando a palavra do "eu" para o próprio corpo em movimento. Nas palavras de Martin Heidegger, a linguagem do ser fala originariamente, e não simplesmente o homem. A poesia telúrica do ser antecede e excede a ciência do homem.

Voltando á cena de João e Valentina, o desejo intenso logo será contido pela razão. A elevação vai tornar-se a queda da alma. O silêncio será rompido pela palavra repressora.

Fui me chegando para mais perto dela, segurei a mão que estava deitada ao meu lado. No primeiro momento ela não reagiu, mas foi consentimento que durou muito pouco. De um pulo ela ficou de pé, vermelhinha olhava para mim. E como o silêncio durava demais, o silêncio que podia nos comprometer, ela disse vamos embora, seu bobo. Por que é que você fica com essas coisas? Assim você atrapalha tudo. Vamos embora que está ficando tarde. (DOURADO, 1999c, p. 86)

Assim como o "céu tinindo de azul" correspondia à leveza dos infantes no evento narrado, agora um outro ser (céu, alma, eu) se desvela mudando tudo.

Só isso, mais nada. Me esqueci: de repente o céu foi perdendo a cor azul, foi se tingindo de cinza, num instante já era fim de tarde, boca da noite. Havia no ar um cheiro gorduroso de mato, um cheiro bom de mato pisado... (DOURADO, 1999c, p. 86)

Nesse ir e vir da narrativa de primeira pessoa, do personagem protagonista ao narrador João, a obra vai nos sugerindo, como diz o próprio 
escritor mineiro, um palimpsesto, uma história subliminar: a verdade dramática de que o ser da própria realidade é trágico. $\mathrm{O}$ mito e a realidade, o nada e o ser, eis o jogo do mundo. As reticências no final da citação anterior e no início da citação seguinte visualmente nos lembram a ruptura ou efeito mortal desse acontecimento na enunciação e no enunciado da vida de João.

\begin{abstract}
... Ah, meu Deus, como tudo se passou tão depressa! Os anjos não tomam conta do tempo. Se a espera e a dor custam tanto a passar, a felicidade acontece tão ligeiro que não dá nem tempo de reparar. Eu súbito descobri a verdade de que a gente só guarda para toda a vida aquilo que dói demais. Num instante chegou a hora do Circo Milano partir.

Fui ao embarque do circo. Na hora da despedida (ainda desta vez a iniciativa era dela) Valentina me deu de surpresa um beijo no rosto. Eu nada podia fazer, o trem começou a andar. (DOURADO, 1999c, p. 86-87)
\end{abstract}

A verdade da morte que brota da própria vida, do ser que emerge do não-ser. O risco do bordado é a morte interior à vida. Na narrativa mítica e dionisíaca de Autran Dourado, o descobrimento da verdade é a escrita da própria morte como o saber lúdico em memória do ser que se vela enquanto se desvela no tempo. Do nada borda-se o ser. Enfim, como nos versos do poema "Ulysses", de Fernando Pessoa, "O mytho é o nada que é tudo" (PESSOA, 1986, p. 6), a verdade da arte é, originariamente, a escrita da morte na vida. A travessia ou viagem do ser miticamente se configura na realidade processual da memória narrativa de O Risco do Bordado. Artista é quem escreve o risco do bordado, ou seja, a própria morte na vida. E, assim, escrever é também escrever-se no horizonte móvel do tempo.

\title{
5.2.4. As Voltas do Filho Pródigo ou O som e a fúria
}

Este quarto bloco narrativo inicia o segundo grupo (bíblico) de $O$ Risco do Bordado. Trata das idas e vindas de tio Zózimo, dos seus périplos entre a razão e a loucura. É narrado em terceira pessoa, configurando-se como uma situação narrativa personativa, de acordo com a caracterização do crítico Franz K. Stanzel já anunciada. Passamos da objetividade do narrador à subjetividade do refletor. Portanto, aqui João retorna como personagem-refletor que, 
miticamente, a partir de suas memórias na forma de monólogos narrados, nos dá a experiência sensível (ver, ouvir, cheirar...) do drama de vida e morte, aflição e terror que atinge a si mesmo, a sua família (vovô Tomé, vovó Naninha e tio Alfredo) e também a cidade.

\begin{abstract}
Alguma coisa no ar dizia que Zózimo estava para chegar. Desde longe, antes mesmo de qualquer anúncio, João pressentia: não demorava muito e tio Zózimo estaria de volta.

Sempre foi assim. Desde que se entendia por gente, aquele mistério; desde quando conseguia lembrar, desde as suas mais antigas lembranças.

Alguma coisa no ar - um som, um cheiro, uma carta - anunciava a chegada de tio Zózimo. O menino desconfiava farejando, tinha os ouvidos muito abertos, os olhos muito agudos, as narinas pegavam um cheirinho diferente no ar, a pele mesmo sentia os sinais de que ele estava para chegar. (DOURADO, 1999c, p. 89)
\end{abstract}

O refletor João é quem nos inicia neste drama familiar e social. Sofremos juntos o sentimento trágico da existência, que não é somente individual, mas coletivo, antes mesmo da chegada física de tio Zózimo.

\footnotetext{
Um dos sinais mais evidentes era o lume de ansiedade nos olhos da avó. Ela ficava aflita pela chegada de seu Zizinho dos Correios, o mensageiro daqueles desastres, toda hora ela indo à janela para ver se seu Zizinho já vinha. [...]

Se João não notava os sinais aflitos nos olhos da avó, os silêncios de vovô Tomé se encarregavam de dizer - aquilo que todos temiam estava para acontecer. [...]

Não que a cidade desgostasse de Zózimo, e perguntassem mais por xeretar, ele era muito estimado. Participavam da dor da família, sabiam que alguma coisa de estranho se passava no casarão de seu Tomé quando Zózimo ia chegar, já tinha chegado. (DOURADO, 1999c, p. 90-91)
}

O menino vai descobrindo a verdade enterrada no coração dos familiares e incorporando a dor de todos, vendo os abismos e descendo aos infernos da existência e refletindo para o leitor o rosto sombrio da morte que de repente se ilumina com a alegria extraordinária da vida. O paradoxo ou visão dionisíaca do homem e do mundo explode como dor e alegria fazendo tremer as bases e certezas de um mundo petrificado pela razão.

A primeira volta ou chegada de tio Zózimo se manifesta corporal e imageticamente num movimento que faz a loucura emergir do fundo da alma e abalar os alicerces da casa paterna. 
Porque nos primeiros dias, quando tio Zózimo chegava, e o silêncio da casa pesava de maneira insuportável, e ele se afundava na rede, de onde só se erguia para gritar, e berrava o seu ódio contra os pais, contra o irmão, contra a cidade, contra o mundo, nem de longe Zózimo podia ver Alfredo. Era com quem ele tinha mais contas a ajustar, conforme dizia. (DOURADO, 1999c, p. 92)

O personagem-refletor João vai desfiando as vozes de aflição e terror da mãe (avó) e do pai (avô) quando do encontro mortal dos dois irmãos Zózimo e Alfredo.

Meu Deus, tem dó de mim, Sagrado Coração de Jesus, ela gritava. É a história outra vez de Abel e Caim! [...]

O avô, que sumia de casa só aparecendo na hora da bóia, só sabia dizer meu Deus, por que ele volta? [...] Por que não se mata de vez longe da minha vista, para esse sofrimento, essa sina, essa agonia acabar de vez? Que culpa tenho eu, Jesus? A velha culpa. (DOURADO, 1999c, p. 92)

O menino, principalmente, assim como todos, aguardavam aflitos que os dias ruins de tio Zózimo se transformassem em calmaria. Mesmo alertado que fosse embora, o menino voltava como que atraído também pela descomunal dor humana e cósmica. Mesmo à distância estava sempre perto do tio numa comunicação silenciosa e sofrida. Observava tudo, sentia o cheiro fúnebre se desprender da natureza e do corpo agonizante de loucura do tio, que nesses dias nem dava pela presença do menino.

João fingia ir embora, voltava. Não podia despregar os olhos da rede,
daquele corpo pesado balangando na sala: os pés de fora da rede,
dava galeios mansos. [...]
Quando soprava o vento da janela do quintal, em vez do hálito das
mangueiras o que vinha era um cheiro rançoso e enjoativo. Será que
tio Zózimo fedia? João nunca chegava perto quando Zózimo ficava
assim. Será que ele não tomava banho? O cheiro que parecia vir de
tio Zózimo grudava no nariz, ou era ilusão? [...]
João tremia diante da figura enorme, magra e cabeluda: a cara
barbada, os olhos fundos cheios de estrias vermelhas. [...]
Nos dias bons até que era muito seu camarada, contava casos dos
lugares por onde tinha andado, se lembrava dos seus tempos de
menino; nos dias ruins ignorava-o inteiramente, era como se ele não
existisse. (DOURADO, 1999c, p. 94)

E tio Zózimo ressurgia de suas sombras interiores, enchendo a casa de luz, som, cheiro e alegria novos. Voltava novamente sem nunca ter saído de 
perto. Epifânica e dionisiacamente, essa visão e essa verdade faziam o mundo nascer de novo de seus abismos.

Porém os dias bons sempre voltavam. E era como se só então tio Zózimo tivesse chegado de viagem. O sinal mais evidente de que tio Zózimo ia voltar era que a rede começava a balançar mais ligeiro. [...] E de repente acontecia. Tio Zózimo saltava da rede, chegava na janela, enchia o peito de ar, esticava os braços distendendo a musculatura feito um gato se espreguiça, e em passadas ligeiras lá ia ele assobiando para o quarto de banho. (DOURADO, 1999c, p. 95)

E João comemorava, dava a boa-nova e anunciava o retorno do tio e da alegria como se ele mesmo tivesse chegado de uma longa viagem interior também.

E tio Zózimo aparecia na sala, barbeado, limpo, bem vestido, até de gravata. Se João estava por perto, Zózimo corria para ele de braços abertos, apertava-o contra o peito, dizendo como é, então, você está me saindo um bom maroto, um rapagão! João sentia aquele corpo quente, o cheiro gostoso e fresco de alguém saído do banho ainda recendendo a sabonete.

Quando João conseguia se livrar do abraço, ele gritava vovó, vem cá, vem ver quem chegou, como se tivesse feito um trato com tio Zózimo. (DOURADO, 1999c, p. 95-96)

E o mesmo ser que afastava, agora aproximava a todos. A mesma morte agora virava a vida em abraços, beijos e sorrisos de vovó Naninha, tia Margarida, Milurde, vovô Tomé e da cidade.

Como por encanto tudo mudava no casarão. Ninguém mais era triste e calado. A notícia se espalhava aos quatro ventos e todos os conhecidos velhos e os velhos amigos vinham em romaria visitar e a casa se enchia de gente conversadeira, alegre, amiga. (DOURADO, 1999c, p. 97)

E o menino-refletor mostra-nos, sensivelmente, como, num instante, o mundo gerava um homem novo, um ser novo, uma verdade nova. Diversas quitandas e frutas eram servidas e comidas como se a própria natureza também comemorasse o renascimento de seu filho amado. A casa do ser e a casa dos homens participavam da mesma festa: "E a casa se povoava do vozeirão de tio Zózimo, das suas risadas gostosas e quentes." (DOURADO, 1999c, p. 97). Até tio Alfredo voltava da fazenda e se reconciliava com o irmão. E nos passeios e conversas com os tios, os monólogos de João nos lembram, 
implicitamente, de como o novo tio Zózimo e suas viagens se pareciam com as de outro ser mítico e terreno que era Valente Valentina. Além, é claro, de outro navegante menino que existia em vovô Tomé quando chegava circo em Duas Pontes.

Tio Alfredo e tio Zózimo tinham conversas intermináveis. Tio Zózimo falava de São Paulo, do Rio de Janeiro, do Recife. Como ele viajou, até parecia cometa, de tanta cidade que ele falava. Só que com tio Zózimo era melhor, as cidades de que os cometas falavam eram perto, tinham nomes comuns, sem a sonoridade, 0 brilho, a luminosidade estridente dos lugares por onde andara o filho pródigo. Tio Zózimo parecia era gente de circo, um circo com todas as luzes acesas. Qualquer dia destes tomo o vapor, vou bater na Europa, vou conhecer o mundo, dizia tia Zózimo alargando as vistas. [...]

[...] Que vidão a de tio Zózimo, ele ia conhecer o mundo! Tio Zózimo devia ser era dono de um circo fantástico. E o menino, de dia de olhos arregalados em bruma ou em sonho, viajava com ele. (DOURADO, 1999c, p. 98)

Entre o mito e a realidade, João viajava pelo mundo, alargava seus horizontes, com as aventuras e palavras de tio Zózimo, mais do que com as de tio Alfredo. Via admirado como, de repente, uma criança divina e navegante, brincando e descobrindo o mundo, emergia das almas dos homens.

E os tios discorriam, como falavam e se lembravam de casos de quando eram meninos! Eu era feito você, João, dizia Zózimo batendo no ombro do menino. Você ainda vai conhecer o mundo e lá longe vai se lembrar de mim. João se babava de estar na companhia de gente tão importante, de ser assim tão considerado. (DOURADO, 1999c, p. 99)

Mas, num instante também, tio Zózimo e a vida partiam de novo. $\mathrm{Na}$ estação, aos olhos do refletor João, a família toda estranha e alegremente se despedia do filho pródigo.

Os dias bons iam passando, passavam depressa. Num átimo dava a sapituca, chegava o dia de tio Zózimo partir. [...] João achava aquilo tudo muito estranho, ninguém chorava quando tio Zózimo ia embora. O choro se guardava era para quando ele estava de volta; depois de muito tempo (primeiro vinham as cartas, a liturgia da catástrofe), tio Zózimo voltava para a casa do pai. (DOURADO, 1999c, p. 99)

Uma outra coisa que intrigava a curiosidade do menino e o levava à constante busca do descobrimento, para além das deformações ou loucuras da alma humana, era um defeito na orelha de tio Zózimo. Uma outra 
aprendizagem da dor vai aos poucos atingir simultaneamente o refletor e 0 leitor.

João não se lembrava desde quando, mas muito menino ainda sempre reparou que tio Zózimo tinha uma coisa esquisita no ouvido direito. O menino reparava demais, passava um tempão olhando de um lado e do outro, comparava as orelhas de tio Zózimo. Quando Zózimo estava de bem com a vida e o menino vivia rabeando-o. (DOURADO, 1999c, p. 99-100)

O menino põe-se então a investigar a orelha de todo mundo, do barbeiro, da mãe, de vovô Tomé, de vovó Naninha para "depois comparar com as orelhas do tio, principalmente o buraquinho do conduto." Mas permanecia na escuridão da ignorância.

\begin{abstract}
Mesmo sem o buraquinho do lado direito, as orelhas de tio Zózimo eram diferentes de todas as orelhas que ele tinha resenhado minuciosamente na rua e em casa. Eram miúdas e duras, rentes à cabeça, refolhudas. Lóbulo quase não havia, a curva acabava diretamente na cara. $O$ ouvido direito é que era diferente, diferente não só do esquerdo mas diferente de tudo quanto era ouvido que ele tinha colecionado. Era redondinho, como feito a compasso, sem pêlo nenhum, ao contrário do outro, que tinha uns tufos saindo para fora.

Ah, meu Deus, se ele pudesse perguntar a alguém, se alguém pudesse lhe dizer por que é que o ouvido de tio Zózimo era tão desigual, tão esquisito! Em casa, por causa daquela resposta da mãe ficou sabendo que era proibido perguntar sobre o defeito, como era proibido indagar quando é que tio Zózimo ia chegar, ele estando longe. (DOURADO, 1999c, p. 102)
\end{abstract}

O refletor-heroi-trágico João então vai em suas aventuras ou viagens de descobrimento ultrapassar as barreiras do segredo, da proibição, da razão e des-cobrir, ou seja, se aprofundar tragicamente na dor desse ouvido que não é só individual (tio Alfredo), mas coletiva (família, cidade). Mais uma vez, assim como no primeiro bloco Viagem à Casa da Ponte, mas num tempo anterior, será o amigo Zito quem vai iniciá-lo neste outro rito de passagem.

Foi Zito que the deu a chave do mistério. Quando João era bem maior, quando não mais se ocupava em ficar observando tio Zózimo, quando vivia reinando com Zito pela cidade na embrulhação do tempo, meninos que eram, desocupados. Isso aconteceu pouco antes dele ir para o internato em São Mateus e Zito começar a trabalhar na loja de seu Bernardino. (DOURADO, 1999c, p. 103) 
Ao perguntar insistentemente ao amigo, entre palavras e silêncios, entre o medo e a curiosidade de saber, o refletor des-cobriu e ouviu a explosão da verdade terrivel em si mesmo: "Olha, João, aquilo foi tiro. Um dia seu tio sapecou um tiro no ouvido!" (DOURADO, 1999c, p. 105). Na narrativa autraniana, o drama é estático, não é cinético. É passional, não é meramente racional ou de ações consecutivas, como na concepção aristotélica.

\begin{abstract}
O tiro explodiu no ouvido do menino, ficou zunindo no ar, sem fim. Ele tonto, aquele som redondo feito o chocar de dois mundos, o ribombar de um trovão quando uma tarde de chumbo de repente no pasto de seu Luquinha ele sozinho, abandonado, perdido. Como se uma trompa fantástica tivesse soado, e os seus sonidos ecoavam pelo mundo afora, por covas e corredores, labirintos e condutos invisíveis, grutas de estalactites (gotas incessantes pingavam no lajedo), por descampados e pisos ladrilhados, corredores de azulejos e campânulas de vidro que súbito se estilhaçavam, ele próprio uma caixa acústica ressoante, um pavilhão e uma concha: as trompas e trombetas do Juízo acordariam vivos e mortos na hora derradeira, todas as lembranças ressurrectas, e tudo se encadeando e se explicando, ele de repente lúcido, pálido e branco porque tomara conhecimento nas suas mais íntimas fibras; e o som golpeando, percutindo, vibrando, araponga que estourasse no seu canto de malho e bigorna. E aquele tiro, aquele estrondo, aquelas paredes ruindo, tetos desabando, vidros partindo, ainda haviam de vibrar durante muito tempo no ar, de vez em quando e sempre, nos sonhos e pesadelos, quando ele acordava empapado de suor no meio da noite, sempre e ainda agora. (DOURADO, 1999c, p. 105-106)
\end{abstract}

Isomorficamente, a cena mimetiza, na forma e no conteúdo, nas palavras e nos sentidos, a verdade dolorida e labiríntica do sentido ouvido. Fundo, física e animicamente, as figuras de João e tio Zózimo, de todos os homens e de todo o mundo, explodem e se desintegram em palavras cheias de som e fúria. Como bem nos afirma Autran Dourado, no texto "Uma segunda ordem de leitura", presente em Uma Poética de Romance: Matéria de Carpintaria:

É no ouvido do menino que estoura o tiro que tio Zózimo dá no seu próprio ouvido. E todas as imagens e símbolos, as palavras dessse trecho, se referem a ouvido; o próprio ritmo circular, labiríntico, onírico, fantástico-naturalista, das frases. (DOURADO, 2000a, p. 50)

Imagética, barroca e apocalipticamente, o eu e o mundo, as palavras e as coisas, o cosmos e o caos, a vida e a morte se integram e se desintegram no texto e na alma do menino marcando para sempre o sonho e a realidade de 
sua/nossa existência. Paradoxalmente, o caos gera outro cosmos, a desordem vira outra ordem, as trevas tornam-se outra luz, o eu devém outro eu. João agora vê, epifânica, dionisíaca e lucidamente, os abismos do ser. Sabe pelo sofrer que a verdade trágica é o ser da própria realidade, e não apenas uma condição humana. Na estrutura narrativa de O Risco do Bordado, o próprio nome do menino João já se revela como símbolo do cosmos e do caos, do início e do fim do homem e do mundo.

E voltando a si, ficou sabendo de tudo. E tudo aquilo que durante tanto tempo esconderam e ele pegava apenas alguns fiapos no ar e com esses fiapos tentava construir a sua história, a sua verdade, de repente tudo lhe foi dado como ele menino imaginava o dia do Juízo Final, quando todos seriam chamados, e todos os pecados, mesmo os que a gente esquece, surgiriam, e todos, vivos e mortos, uns diante dos outros, despudoradamente, veriam a verdade terrível de cada um, e as coisas então fazendo sentido na claridade estridente da nova manhã. (DOURADO, 1999c, p. 106)

João é a criança dionisíaca, a máscara que reflete ou revela a aliança trágica do ser e do nada, da vida e da morte. A metáfora e o símbolo do mundo e do homem.

Agora tudo se casava perfeitamente, tudo tinha explicação. [...] Ele não precisa mais perguntar a ninguém as razões de todo o segredo que cercava as voltas de tio Zózimo, o mistério que vibrava tenso no casarão. Agora sabia, ele menino tinha percorrido sozinho os passos que levam ao conhecimento da dor. Sabia, era senhor do segredo. E como sabia, passou a participar dos acontecimentos, dos preparativos para a chegada de tio Zózimo. (DOURADO, 1999c, p. 106-107)

O menino que sabe o segredo da dor e da alegria é quem agora anuncia a todos a chegada do filho pródigo. Miticamente, senhor da fortaleza e da fraqueza, criança divina e humana.

Agora era João que ficava aflito, toda hora chegando na janela para ver se vinha seu Zizinho dos Correios com carta de tio Zózimo. Já que sabia, precisava conferir com a presença do tio o seu conhecimento. (DOURADO, 1999c, p. 107)

João é o mensageiro, o hermeneuta, que liga as duas pontes do mundo distante e do mundo próximo, do passado e do presente, do familiar e do estranho. Foi ele quem primeiro entregou à vovó Naninha a boa novidade da 
carta de tio Zózimo. No princípio, estavam mudamente apreensivos com o conteúdo, mas logo todos se alegraram com as "palavras boas" da carta.

Nunca uma carta provocou tanta alegria. Como visse que a carta era boa e só trazia boas notícias, João também não se conteve, saiu a dizer a todo mundo que tinham recebido carta de tio Zózimo, não demorava muito ele estaria de volta. Todos na rua se alegravam, participando da festa. (DOURADO, 1999c, p. 108)

Mas, em O Risco do Bordado, tudo é momentâneo, evanescente, móvel desde a enunciação ao enunciado. Na metáfora estrutural desta obra, o ser é contínua deveniência.

Quando um dia tio Zózimo chegou. Ao contrário do que João esperava, não foram à estação, ainda havia no chão da alma uma ligeira sombra, um medo que não conseguiam apagar: aquilo tudo podia não ser verdade.

Tio Zózimo chegou, foi o mesmo que um circo tivesse chegado na cidade. Tio Zózimo parecia um Santíssimo Sacramento, de tanta gente em volta dele. (DOURADO, 1999c, p. 108)

O narrador personativo também nos anuncia as cartas que o menino João, futuro escritor, elaborava sobre as experiências familiares. Metaficcionalmente, em seu macro e microcosmos, a obra está sempre a falar da existência e da arte como jogo de escrita da morte.

A chegada de tio Zózimo em casa foi indescritível, escreveu João numa carta fictícia (foi aí que começou o vício de fingir que escrevia para alguém imaginário), nunca tinha escrito a ninguém, a primeira carta de verdade que escreveu foi quando depois ele foi para o Colégio São Mateus.

Tio Zózimo chegou. Chegou o corpo de tio Zózimo, chegou a alma de tio Zózimo na garupa, os dois vieram juntos pela primeira vez. [...] Ele não voltava para a casa do pai porque doente, nevoento, desgastado, mas atendendo ao chamado do amor. (DOURADO, 1999c, p. 109)

De repente acreditaram, com o passar dos dias, que "talvez tio Zózimo ficasse para sempre, nunca mais ele partiria." Mas os monólogos e questionamentos do refletor João pressentem outra verdade.

Mas tio Zózimo não era de ficar. Via-se nos gestos pouco a pouco inquietos, nos olhos de tardinha fascinados pelo azul, perdidos nos longes das grandes distâncias - os olhos do navegador e do andejo. De vez em quando, no meio dos risos e brincadeiras, começou a aparecer uma ponta de amargura, uma nuvenzinha triste boiando. No 
seu medo, João pressentia - alguma coisa estava para acontecer, era capaz de tio Zózimo novamente partir. Ai, meu Deus, será que ele ia buscar de novo o seu deserto? Será que ele ia ajustar outra vez as sandálias aos pés e ganhar o seu caminho, para depois de muito tempo tornar abatido, devastado, e tudo voltaria a ser como era antes? (DOURADO, 1999c, p. 109)

Na manhã do dia da partida de tio Zózimo, o menino João veio bem cedinho para a casa do avô, pois "queria conversar com ele, gozar ainda uma última vez a sua presença" (DOURADO, 1999c, p. 110). Procurou por ele, mas não o encontrou no quarto, onde havia apenas um envelope que se destinava "a quem interessar possa".

O coração batia fundo, João sem coragem de ler a carta. A quem interessar possa, ele se interessava. Que coisa, tio Zózimo! Saiu correndo à procura da avó. Na sala de jantar deu de cara com vovô Tomé. (DOURADO, 1999c, p. 111)

Enquanto procuravam pelo tio, o drama do refletor menino prenunciava o risco do bordado: "Vovô, quem sabe ele foi-se embora, não aconteceu nada de ruim com ele? arriscou João" (DOURADO, 1999c, p. 111). E, epifanicamente, no quartinho da despensa trancado por dentro, cuja porta tiveram que arrombar, todos encontraram definitivamente 0 inesperado que também é esperado.

De repente viram: a banqueta caída no chão, tio Zózimo dependurado por uma corda amarrada na viga do teto.

Quando o enterro de tio Zózimo saiu, tinha-se a certeza de que aquela era a sua última partida, ele não voltaria nunca mais. (DOURADO, 1999c, p. 111)

Nas idas e voltas do narrador personativo e do personagem-refletor, dos homens e do mundo, acontece o eterno jogo da morte e da vida em O Risco do Bordado.

\subsubsection{Assunto de Família ou O rio do nada}

Neste quinto bloco, pertencente ainda ao segundo grupo (bíblico), encontramos a "biografia" de vovô Tomé. Trata-se de uma situação narrativa 
personativa em terceira pessoa em que, paradoxalmente, o próprio vovô Tomé é o narrador e o personagem refletor. O menino João é um personagem oculto, apenas ouvinte. Como bem nos alerta Autran Dourado, no texto "Narrativa em blocos e falsa pessoa", presente em Uma Poética de Romance: Matéria de Carpintaria:

\begin{abstract}
Embora escrita na terceira pessoa, reparando bem se verá que é uma falsa terceira pessoa. [...] Pode-se passar a narrativa para a primeira pessoa (como foi inicialmente escrito Assunto de Família) e se verá então perfeitamente o que estou dizendo. É vovô Tomé contando para o menino (não sei se era menino ou se já era homem, deixei a coisa propositadamente vaga e ambígua - a cronologia de $O$ Risco do Bordado é bem barroca e complicada) um caso que se passou entre ele e o pai dele, o bisavô Zé Mariano. É uma longa confissão do velho Tomé para o neto. [...] Repare-se como as negaças e esquivanças do velho parecem variar com o espanto que ele vê nos olhos do menino. (DOURADO, 2000a, p. 26)
\end{abstract}

Nessa transposição de uma narrativa inicialmente escrita em primeira pessoa para uma situação narrativa escrita em falsa terceira pessoa, Autran Dourado lucidamente não só evita a "monotonia de uma longa confissão", como também consegue um "efeito" de ambiguidade, a saber: "Um distanciamento e profundidade maior, uma impressão de estranheza e obscuridade, de mistério e absurdo, de meios-tons e claros-escuros." (DOURADO, 2000a, p. 28)

O Risco do Bordado não é uma narrativa tradicionalmente linear, mas moderna, aberta e verticalmente construída em blocos. Portanto, o seu narrador em terceira pessoa não implica uma onisciência, "saber de Deus, para quem nada é obscuro". Desde o romance Tempo de Amar [1952], o escritor mineiro obtém esses efeitos de ambiguidade a partir das mudanças verbais e dos blocos. Reconhece o seu débito com relação à técnica do refletor promovida por Flaubert e Henry James, bem como ao olho-câmera do cinema. Nessa linha, o verbo e o substantivo (personagem) são compreendidos dinamicamente de acordo com o ritmo da narrativa. O personagem é visto como imagem ou metáfora.

Uso na mesma frase o passado e o imperfeito [...] como técnica de descrição e narração, para o movimento, para alcançar uma aproximação ou afastamento do objeto ou da cena, conforme o caso. 
Como se fosse uma câmera que vai do long-shot ao close-up ou ao contrário. (DOURADO, 2000a, p. 36)

Na situação narrativa personativa de Assunto de Família, o narrador e 0 personagem-refletor são um e o mesmo vovô Tomé, que, em falsa terceira pessoa, conta a João o que se passou entre ele, a mãe dona Pequetita e o pai Zé Mariano. O menino João se identifica com ele no remorso e na culpa.

De uns tempos para cá estou sempre pensando na morte de meu pai, continuava ele. [...] Depois que tio Zózimo morreu é que a coisa voltou, durava dias e dias. Não pregava os olhos de noite, a cisma enxameando a alma de fuligem. Para buscar alívio, vivia dizendo que não era o único culpado. Culpa maior cabia à mãe dele, vovô Tomé tinha sido apenas a mão estendida. [...]

Ficava mentindo a si mesmo, não era um boneco, pensava ao mesmo tempo que fazia. Porque podia ter deixado de fazer, podia ter desobedecido a mãe. Quem sabe eu não cumprindo o sopro de minha mãe nada daquilo tinha acontecido, ele se perguntava. (DOURADO, 1999c, p. 113-114)

Vovô Tomé sofreu a dupla dor como pai de Zózimo e como filho de Zé Mariano. Os mortos o perseguem em vida.

Às vezes vovô Tomé achava que tio Zózimo tinha puxado ao pai dele, era muito parecido com o bisavô Zé Mariano. Não como era Zé Mariano na força da idade (lembrava-se do velho: vovô menino, já graúdo, homem feito) mas igual ao pai no fim da vida, quando aquela coisa deu nele. (DOURADO, 1999c, p. 113)

Confessa que tinha algo de parecido com o pai, não por fora, mas por dentro: "Aquele jeito de aguentar calado, a sua mudez escura de bicho. Zé Mariano aguentava tudo da mulher, purgava um pecado antigo. (DOURADO, 1999c, p. 115)

Assim como o pai, em relação à mãe, vovô Tomé aguentava as ofensas do filho Zózimo.

Os modos, o jeitão do pai, que vovô Tomé procurava depois remedar. Quando teve de aguentar calado aquelas injúrias todas de tio Zózimo. Quando, por carta e por boca, mesmo em pessoa, tio Zózimo ofendia. Quando tio Zózimo ofendia ele ficava calado aguentando no lombo as chibatadas da sua língua, vovô Tomé copiava era o pai (eu mesmo, sem comando de ninguém, me impunha a penitência). Aguentava tudo sem tugir nem mugir, suportava na carne o discorrer doído da vida de tio Zózimo. Quando pensava no filho distante, ou Zózimo 
perto, ali chegado mas longe, vovô Tomé só sabia dizer é assim, tem de ser assim, cada um com o seu tanto, conforme a partilha de Deus. (DOURADO, 1999c, p. 115-116)

Deste início confuso da narrativa, dessas ruminações de vovô Tomé, aos poucos vai contando ordenadamente a João o que se passou com ele e o pai Zé Mariano. Da semelhança inicial que fez de Zózimo com Zé Mariano, vai agora buscando diferenças.

Não, o pai não era que nem Zózimo. O velho Zé Mariano estava era de miolo mole, nas cãs da caduquice, conforme então pensava. Zózimo sempre foi de juízo virado, maluco de todo. Eu disse de miolo mole mais para me acalmar, vovô Tomé vivia dizendo. Hoje tinha muitas cismas se o pai estava mesmo de miolo mole, se não tinha razão de fazer aquilo que fez. (DOURADO, 1999c, p. 116-117)

A culpa de vovô Tomé vai inundando a narrativa e contaminando o menino João que ouve atentamente e compartilha a sua dor. Está sempre em busca de uma razão pras coisas e atitudes do pai, "se arrimando em muleta para aguentar a alma na escuridão."

O pai tinha carradas de razão para fazer aquilo que fez, quando se mandou de vez para o Sítio da Barra e foi ficar morando com o seu filho pardo Teodomiro, por ele tido e reconhecido como filho - tanto que foi ele que deu, de papel em cartório, aquele naco de terra de que Teodomiro fez o Sítio da Barra. (DOURADO, 1999c, p. 117)

Aos olhos de vovô Tomé, esse acontecimento, esse filho anterior ao casamento do pai, a princípio não parecia ser problema para a mãe. Mas como filho de dona Pequetita (Madalena), vovô Tomé conhecia a ferocidade de sua natureza interior por trás da mansidão.

\footnotetext{
Mas a mãe não era nada disso, a mãe era uma onça de braba. [...] $\mathrm{A}$ brabeza e a ciumada da mãe não tinham barreira. [...] Não só quando menino ele obedecia. Homem feito, mesmo depois de casado (quando e com quem ela consentiu, foi dona Pequetita que escolheu), vovô Tomé sempre punha muito tento e cabeça baixa nas ordens de sua mãe. (DOURADO, 1999c, p. 118)
}

Na descrição de vovô Tomé, percebe-se a natureza dupla da mãe, humana e selvagem. 
A ciumada da mãe já era doença. Não só do marido e dos filhos, mesmo dos empregados e crias da casa ela tinha ciúmes. Qualquer coisa que ela repousasse os olhos ficava the pertencendo, e era um pertence guardado debaixo de sete chaves, com unhas e dentes, feito uma loba de cria nova. [...]

A mãe baixotinha, seu nome era Madalena mas ficou sendo desde menina dona Pequetita, o apelido conforme o seu feitio. [...] Com os anos ela foi criando uma sombra de bigode debaixo do nariz, uns fios de barba soltos no queixo, diziam que dos ovários [...]. (DOURADO, 1999c, p. 119)

Dona Pequetita não gostava de roça, motivo constante de atritos com o marido Zé Mariano, ao ponto de obrigá-lo a montar também casa na cidade. $\mathrm{E}$ vovô Tomé não ousava contrariá-la.

Vovô Tomé tinha medo da mãe, punha sentido nos seus mínimos gestos. Mesmo mandona e ciumenta [...], mesmo assim fechada e seca, ele tinha pela mãe um amor além da conta. E ela desconfiava, sem ele carecer de falar a mãe sabia. E sabendo, usava, fazia do filho pau-mandado. (DOURADO, 1999c, p. 120)

O que funcionava com o filho não funcionava com o marido: "O pai não obedecia, aguentava." A convivência entre os dois era uma luta diária: "Mas com o tempo o velho Zé Mariano foi perdendo o ânimo, ao contrário da mulher - cada ano que passava ela ganhava mais em força e soberania" (DOURADO, 1999c, p. 120). Doente o pai, a mãe passou a dar as ordens na fazenda: "E suas ordens, ciciadas ou mudas, sem ponderação e meia-volta, eram terríveis (DOURADO, 1999c, p. 121). Antes de casar Zé Mariano era todo vitalidade, fortaleza e trabalho, agora cada vez mais afundava nas sombras e silêncios da alma.

O velho Zé Mariano desgostoso com a situação definhava fisicamente e animicamente: "Se já era de pouca fala dentro de casa, emudeceu de todo." À medida que melhorava, foi planejando a fuga daquela prisão.

Disse filho, não diga nada pra ninguém (ele queria dizer sua mãe), amanhã você me arranja um cavalo. [...] E outra vez: ninguém (ele queria dizer sua mãe) carece de saber. Se ficar aqui plantado eu morro, disse de fôlego curto. (DOURADO, 1999c, p. 122) 
Dona Pequetita descobre, indignada, pelo filho Tomé, que o marido Zé Mariano fugiu e foi morar no Sítio da Barra com seu filho Teodomiro. As coisas fugiam ao seu controle.

Foi o mesmo que uma punhalada no peito da mãe. Ela deu um passo atrás, procurou-se apoiar para não cair. O Sítio da Barra queria dizer Teodomiro, Teodomiro queria dizer a mãe dele, a mãe dele queria dizer o passado do marido, e no passado do marido ela não tinha mando nenhum. Mesmo morta a mãe de Teodomiro, para dona Pequetita era como se estivesse viva, tinha vindo cobrar meu pai. $\mathrm{Na}$ fundura do coração ela sentiu que o marido tinha bandeado. E ela estava sozinha, humilhada, traída. (DOURADO, 1999c, p. 124)

Dias depois, vovô Tomé vai ao encontro do pai. Ao ser recebido pelo irmão de sangue Teodomiro com quem nunca tinha falado, experimenta a estranheza do momento. Temos aqui a refletorização de vovô Tomé em seu drama estático. A emoção dramática é a interação do ser e do tempo, ou melhor, do ser e do nada.

A mão esticada, esperava seu Teodomiro. A mão de seu Teodomiro tão diferente da sua: a palma esbranquiçada, as costas da mão mulatas. $O$ coração batia fundo na espera, tinha muita emoção. $O$ mesmo sangue seu naquela mão, o mesmo sangue do pai correndo dentro dos dois. [...]

A demora foi coisa de uma nada, a emoção é que esticava o tempo. (DOURADO, 1999c, p. 124-125)

Nessa narrativa em falsa terceira pessoa de vovô Tomé ao menino João, vamos conhecendo seus receios, suas indagações, seus modos de ser: "Aflição é assim mesmo, costumava dizer vovô Tomé, a gente cuida de coisas disparatadas, daquilo que adivinha o coração carregado, feito ver assombração de dia." (DOURADO, 1999c, p. 127-128)

Ao encontrar o pai, vovô Tomé se emociona e reconhece que ele estava bem melhor do que em sua casa, pois "não tinha mais aquela aflição nos olhos, aquela fala agoniada." O pai pede para que ele tome conta da Fazenda do Carapina, no lugar de sua mãe.

O pai Ihe passava o bastão, que nem Abraão a Isaac, Isaac a Jacó, Jacó a José. Vovô Tomé se lembrava das histórias de bíblia que a mãe gostava de contar quando ele era menino, aqueles filhos 
preferidos. E sentiu um nó na garganta ao receber a solene benção do pai. (DOURADO, 1999c, p. 128)

$\mathrm{Na}$ despedida, perguntou ao pai se não voltaria pra casa. E as palavras e os silêncios do velho Zé Mariano revelaram a decisão de outra vida, um contentamento descontente.

\begin{abstract}
Não, filho, volto mais não. Você querendo me ver, venha, me dá muita alegria. Venha, filho, venha mais vezes, você aqui será sempre bem agasalhado, ele pedia, e vovô Tomé viu então pela primeira vez na vida os olhos do pai cheinhos de lágrima. No repente da emoção ele se rendia, vovô Tomé teve medo de que o pai garrasse a chorar feito menino, e vovô Tomé não ia saber como lidar com um velho chorando, era demais para ele. Mas o pai baixou a cabeça para o filho não ver, ele era muito delicado, mesmo sendo um homem crescido na dureza da vida. Quando, já montado, vovô Tomé disse adeus pai, o pai abanou a mão desajeitado. Viu que o pai era triste mas feliz. Picou ligeiro o cavalo, queria fugir da emoção. (DOURADO, 1999c, p. 130-131)
\end{abstract}

Vovô Tomé é quem une as duas pontas ou margens entre o pai e a mãe. É quem envia notícias de um mundo ao outro. Assim vai descobrindo outras faces do pai: "Ele era novo da banda do pai, o pai tinha sido sempre para ele muito encoberto, só agora, a nuvem afastando, é que começava a ver direito a sua figura." (DOURADO, 1999c, p. 131). E percebendo a mágoa e o rancor da mãe por ter sido abandonada. Mas também sentindo ciúmes de seu irmão Teodomiro estar mais próximo do pai do que ele.

Nas idas e vindas de uma casa à outra, vai carregando a dor e a alegria de si mesmo e de todos. Sabia que o pai estava velho e cada vez mais doente. Quando voltou ao Sítio da Barra, ficou impressionado com o estado do pai.

O pai falou pouco, quase nada, só perguntou como ele ia. Não disse nada de desencontrado mas tinha os olhos neblinados, não punha sentido nas coisas. Olhava parado a porta aberta, os olhos mergulhados nos longes de uma nuvenzinha boiando no céu estalando de azul, mas vovô Tomé via que o pai não estava espiando aquele algodão de nuvem, o pai olhava era o oco do vazio, a lonjura das ausências. (DOURADO, 1999c, p. 133)

Vovô Tomé sente-se culpado de não estar ao lado do pai, cuidando dele, diminuindo a sua solidão. Em suas reflexões doloridas, lucidamente fala ao menino João acerca da natureza humana. 
Meu pai sempre foi um homem sozinho, dizia vovô Tomé, e um homem sozinho se perde à toa à toa. Um homem sozinho tem de se agarrar nas coisas, do contrário a barca se extravia, quando vê está de bubuia no rio do nada, afundado no vazio das brumas. (DOURADO, 1999c, p. 134)

A narrativa autraniana constantemente repete expressões que sugerem a inconstância e deveniência de todas as coisas, que mostram a temporalidade e finitude atingindo o ser do homem e do mundo. Imagens que produzem "efeitos" de ambiguidade, meios-tons e claros-escuros, nas palavras do escritor mineiro: "oco do vazio", "Ionjura das ausências", "rio do nada", "vazio das brumas". Noutras palavras, a narrativa dramática de O Risco do Bordado representa, em seus blocos narrativos, recorrentemente, a insubstancialidade da natureza e da natureza humana, o nada como véu do ser. A morte como o risco do bordado da vida.

Estamos diante de uma prosa poética rigorosamente trabalhada para produzir no leitor os efeitos de ambiguidade, passionalidade, mistério e evanescência do ser desde o plano da enunciação ao plano do enunciado. Como disse o autor aludindo a Edgar Allan Poe e Gustave Flaubert, a narrativa deve ser um "maquinismo de efeitos", aliando, ao mesmo tempo, precisão e mistério

Retornando às viagens de vovô Tomé da casa do pai à casa da mãe, nota-se que o drama de paixão e morte vai se acentuando, sobretudo em dona Pequetita.

Você acha que ele volta algum dia, Tomé? Vovô Tomé sentiu que não podia mentir para ela outra vez (a gente tinha que se acostumar com a verdade, não podia viver mentindo). Não, mãe, eu vou ser franco com a senhora. Mesmo pai melhorando, ficando bom de todo, eu acho que ele não volta nunca mais.

A mãe sentiu na carne o vergão do chicote. Pensou que ela fosse gritar, desabar sobre ele a mágoa que ela sentia do marido. Ela fez tudo ao contrário: baixou a cabeça, e mesmo disfarçando não pôde impedir que vovô Tomé visse que ela sungava uma lágrima. Abracei minha mãe tão pequenininha, dizia vovô Tomé, apertei ela bem junto do peito, minha mãe agora é que carecia de proteção e abrigo carinhoso. Mas a mãe não era de chorar, disse vamos pra dentro, filho, que está esfriando, a voz nem um pouquinho molhada. (DOURADO, 1999c, p. 135-136) 
As mudanças do ser, as diversas faces da natureza e da natureza humana, os outros eus, esses são os movimentos lúdicos e dramáticos de $O$ Risco do Bordado. As viagens vão do mundo físico ao mundo anímico, descobrindo as faces delicadas e terríveis do ser humano.

\begin{abstract}
Foi daí em diante que a mãe mudou. Ela passou a dar vazão a todo o seu ciúme, a todo o seu ódio poupado. [...]

Ela parece que se conformou, resolveu viver a sua mágoa, cortou para si a vestimenta mais bonita, fazia a figura da mulher abandonada, sofrida, sozinha no mundo. Mesmo assim, volta e meia o rio engrossava, ela dizia a gente não tem que se ocupar dele, meu filho. Ele que se cuide, fique lá com a sua nova família. Já que não tem coração, não liga pra gente. E para não dar parte de fraca: por mim não, que nunca lhe dei essas confianças de gostar. (DOURADO, 1999c, p. 136-137)
\end{abstract}

Nessas lembranças de vovô Tomé ao menino João, reflexões e ensinamentos vão desvelando a consciência da finitude humana. No jogo do mundo, não só jogamos, mas também somos jogados e co-jogados pelo sentido da verdade: "Mas as coisas não se acomodam ao desejo da gente, dizia vovô Tomé, o mundo é muito desigual nos seus caminhos, o risco não é a gente que traça." (DOURADO, 1999c, p. 137)

Nas idas ao Sítio da Barra, vovô Tomé reparava que o pai andava muito sujo, e descobriu, nas conversas com Teodomiro, que ele, por teimosia, não tomava banho há uma ano. Como nos outros blocos narrativos, a obra destaca as imagens do cheiro e do suor muitas vezes como representação do corpo que se desvanece e apodrece impregnando a todos.

O pai estava imundo de fazer dó. Quando ele suava, um suor preto escorria pela cara, ele passava a mão, limpava nas calças que não tinham mais cor, só então vovô Tomé reparou. O pai parecia um pobre de pedir, desses que batem de porta em porta dia de sábado. Ele tinha vergonha do pai, não sabia o que fazer. Além da pena, a vergonha: se sentia por dentro um trapo sujo, que nem o pai por fora. O pior de tudo foi o cheiro que passou a sentir. Não podia ficar muito tempo junto dele, se afastava do pai logo sentia o cheirinho azedo, entre manteiga rançosa e carne podre. Nunca tinha visto aquilo em gente de bem, na sua família sempre se cuidou muito do asseio. $O$ pai estava entregue à sua sujeira; ao seu fedor. [...] Agora parecia um bicho, de tão sujo e descabelado. (DOURADO, 1999c, p. 138) 
Além de incorporar a dor, a culpa, vovô Tomé incorpora também agora a imundície do pai. Sente o cheiro não só na presença como também nos sonhos e nas lembranças de seu Zé Mariano.

De repente aquela visão de bicho afogou a alma. Afinal ele era seu pai, por mais que não quisesse se lembrar dele quando longe dali. Quem fedia era eu, dizia vovô Tomé, eu era imundo por dentro, me acusei. (DOURADO, 1999c, p. 139)

Acaba revelando o assunto para a própria mãe, que ficou furiosa e indignada com a situação. E junto com o filho buscaram um jeito de solucionar o problema. Numa outra visita ao pai, que "boiava nas cinzas da neblina, os ollhos de pano sujo", arquitetou o plano. Entre o medo de matar e a vontade de ajudar o pai, levou-o a um passeio à beira do rio.

Eu sempre que via um rio por entre um mato, dizia vovô Tomé, meu coração saltava de alegria. Daquela vez não, o coração vinha carregado de medo, encharcado de sombra. Não tinha mais mão em si, caminhava sonâmbulo. (DOURADO, 1999c, p. 143)

Quando se aproximou, vovô Tomé colocou em prática o plano da mãe. Empurrou o pai no rio na esperança de livrá-lo da sujeira. O medo the imobilizava.

E viu o que nunca cuidou de ver, viu o que o seu coração mais tinha
medo. Viu o braço do pai se levantar para o ar, na sua direção. O pai
gritava nomes, amaldiçoava. Vovô Tomé não ouvia, não queria, não
podia ouvir.
Como aguentar aquela mão, aqueles gritos? Saiu numa desabalada
louca. Passou por seu Teodomiro, nem olhou para ele, saltou em
cima do cavalo, correu léguas de desvario. (DOURADO, 1999c, p.
143)

Vovô Tomé aguardou notícias por três dias ("três dias que foram a minha agonia, a minha morte temporã") até que o mandaram chamar e, assim, retornou armado ao Sítio da Barra. Enfrentou a fúria mortal do irmão Teodomiro e quase saíra na bala. Soube que o pai, desde aquele dia, não falou mais com Teodomiro e a esposa Vitoriana e, no outro dia, juntou os trapos, pegou um rolo de fumo e se trancou por dentro numa cafua, numa meia tapera distante dali e não abria a porta pra ninguém. Teodomiro insistia várias vezes para que o pai abrisse a porta, levava-Ihe comida, tudo em vão. Depois encarregou o 
menino de levar sempre a marmita. Responsabilizou vovô Tomé pelo acontecimento: "O senhor sabe que a culpa de tudo que acontecer daqui pra frente é sua?" (DOURADO, 1999c, p. 145)

Os dias seguintes de vovô Tomé foram de "brumado e pesadelo". Já não falava com a mãe, padeciam em silêncio. la todo dia ao Sítio da Barra em busca de notícias do pai, nada de novo. Até que um dia a novidade ou verdade terrível se manifestou.

\begin{abstract}
A novidade veio um dia, seu Teodomiro foi quem contou. Às vezes o menino voltava com a marmita cheia e dizia é de ontem, ele nem provou. Não estranhavam muito, velho às vezes é sempre meio enfastiado. Seu Teodomiro só mais tarde é que desconfiou da verdade. O velho devia passar dias e dias sem comer, só pitando no escuro, nem a janela ele abria. O menino jogava a comida no rio ou se fartava com a marmita, ele era um tanto arado. Muito ladino, fazia as coisas de modo que não dava para desconfiar. Só depois é que ficaram sabendo. Quando um dia alguém veio correndo dizer que estava assim de urubu em cima da casinha do pai. (DOURADO, 1999c, p. 146)
\end{abstract}

Assunto de Família dramatiza, portanto, o remorso e a culpa trágica do filho e do pai, do avô e do neto nesta narrativa de falsa terceira pessoa. $O$ narrador personativo vovô Tomé, o personagem ouvinte menino João e o leitor experimentam, nas memórias que viajam do passado ao presente, neste rio do nada, que é o próprio ser, as dores trágicas de uma realidade constantemente perseguida pela morte.

\title{
5.2.6. O Salto do Touro ou O labirinto do tempo
}

Neste sexto bloco, que fecha o segundo grupo (bíblico), encontramos uma situação narrativa personativa escrita em terceira pessoa e tendo como personagem-refletor João. $O$ narrador personativo se desdobra e personifica 0 personagem-refletor que nos apresenta as suas memórias, visões ou impressões sensíveis e doloridas acerca de tia Margarida, de si mesmo e do mundo. As reflexões de João neste bloco destacam as experiências acerca da passagem do tempo e da trama da morte como matriz estrutural ou chave hermenêutica de $O$ Risco do Bordado. Noutras palavras, os labirintos do tempo 
e do eu constituem o rio corrente da morte que incessantemente modifica a natureza e a natureza humana. A narrativa mítica aliada à técnica do refletor produz no leitor o efeito de indeterminação e evanescência que transforma as memórias num ritmo poético incessante de velamento e desvelamento do ser. A ontologia da obra de arte autraniana implica o reconhecimento de que a linguagem poética fala anteriormente à concepção racional do homem e do mundo. O tempo ontológico da narrativa dramática de O Risco do Bordado antecede a sua delimitação cronológica tanto na sua enunciação quanto no seu enunciado. O labirinto do tempo é a casa do ser que incessantemente ressurge de sua própria morte. A linguagem do ser fala, originariamente, e não simplesmente o homem. O homem fala correspondendo ao silencioso apelo do ser no horizonte móvel do tempo.

\begin{abstract}
Que idade ele teria quando aquilo primeiro aconteceu? Mergulhava no ventre do tempo, nas suas águas lodosas, à procura de algum sinal. Tentava sair do tempo, da densa nebulosa que tudo abarcava e dissolvia, e buscava algum sinal, um acontecimento qualquer de calendário ou folhinha, que lhe desse a certeza de sua idade naquela época, quando aquilo primeiro aconteceu. Tudo dentro dele era pesado e brumoso, doía quando tentava localizar no tempo, deter em suas cores fugidias a figura de tia Margarida. (DOURADO, 1999c, p. 147)
\end{abstract}

Esse início da narrativa nos coloca diante de um verdadeiro labirinto de composição. Na incerteza do tempo e do ser, o narrador personativo, o personagem-refletor e o leitor estão diante de um mistério que não se desvelará progressivamente, mas fragmentariamente nas recordações e fluxos de consciência de João. Sinais e símbolos referentes ao tempo, ao rio e às mudanças do ser aos poucos nos indicarão a chave hermenêutica de O Risco do Bordado. Nas palavras de Autran Dourado, no texto "Planta baixa de um livro", presente em Uma Poética de Romance: Matéria de Carpintaria, esse sexto bloco narrativo

chamava para si todas as linhas internas da composição dos demais blocos, unindo-os através da simbologia - labirinto, jovem e Minotauro, num livro em que o mito principal é o Tempo, embora um tempo não-cronológico. [...] O próprio O Salto do Touro começa com esta indagação: "Que idade ele teria quando aquilo primeiro aconteceu?" Para dar em seguida a luta do menino "mergulhando no tempo", "tentando sair do tempo", perdido no labirinto do tempo, procurando seguir um fio de Ariadne - a narração - sem nunca 
porém precisar com rigor a idade do menino. (DOURADO, 2000a, p. 73-74)

O bloco narrativo inicia com 0 velamento do acontecimento da experiência de João. Nada é dito, tudo é sugerido. Através da justaposição descontínua de imagens, o sentido vai sendo desvelado. No tom "pesado e brumoso", a alma dolorida de João se comunica com a de vovô Tomé no bloco anterior Assunto de Família. A culpa trágica os une.

Pelas contas, devia ter uns dezesseis anos. [...] Aos dezesseis foi que começou a explodir dentro dele o seu corpo de homem. [...]

Foi numas férias de julho, voltando a Duas Pontes, que aquilo primeiro aconteceu. (DOURADO, 1999c, p. 148)

Aquilo aconteceu na casa de vovô Tomé, onde a família (vovó Naninha, tia Margarida, vovô Tomé, João e a preta Milurde) se reunia silenciosa em volta da grande mesa de vinhático: "Mesa lustrosa de velha com seus riscos e estrias, seus caminhos e deltas, suas ligeiras saliências, ilhas e reentrâncias a hidro-orografia do sonho." (DOURADO, 1999c, p. 149)

"Depois que aquilo primeiro aconteceu, abandonou o círculo silencioso e agasalhado em volta da mesa da sala" (DOURADO, 1999c, p. 149), relembra o refletor João. A imagem da mesa como correlato objetivo das "águas" do tempo em que mergulhava João. Mesa que unia e agora separava; água que era vida e agora era morte.

Antes daquilo acontecer, João reparava em tia Margarida, sempre jogando paciência e lendo.

Muitas vezes ele se perdia imaginando, mentalmente compondo uma outra figura com os restos de beleza que a tia forçava por esconder detrás da sisudez precoce, e ele descobria, descascando uma a uma as camadas com que ela procurava se soterrar, a sua alegre beleza. (DOURADO, 1999c, p. 150-151)

O refletor João é quem vai nos des-cobrindo as faces de tia Margarida. No princípio, quando ela tinha por volta dos 28 anos, a face inteligível, apolínea, medida como a esmagar a vida que quer brotar, numa aversão ao tempo da sua jovialidade. Um rosto sem rosto, camuflado, duplo. 
$\mathrm{Na}$ verdade não se podia nunca saber como era tia Margarida, tanto ela se escondia. Ela compunha para os outros e para si mesma uma figura ponderada, pacientemente medida, toda serenidade $e$ complacência, distendida. Queria que o tempo passasse depressa, queria correr léguas no tempo, avançar além da sua idade, num átimo ser uma solteirona bem velhinha. (DOURADO, 1999c, p. 151)

Como o tio Zózimo e o bisavô Zé Mariano, tia Margarida desvivia em sua solidão ou desvitalizava-se em sua razão. Diluía-se nas águas do tempo, se perdia nas brumas do não-ser.

Sem amor, de indefinida idade, na parecença mais velha, os olhos agudos ou vagos boiando às vezes em névoas distantes, era uma sombra leitosa que vagava de mansinho pelos corredores, pelos quartos, pelas salas, pela vida. (DOURADO, 1999c, p. 151)

João agora apresentava a outra face de tia Margarida, por trás do rosto petrificado pela razão. Do fundo de sua alma, a irrupção convulsiva do sensível. Por instantes, as águas mortas viravam águas vivas.

Alguma coisa de tia Margarida não devia caber nesse esquadro. De vez em quando aquelas águas paradas se agitavam. Era quando dela se apossava um súbito nervosismo, uma inquietação desmedida. [...] Quando os olhos, mais inquietos que de costume, crescidos pela aflição, procuravam alguma coisa que ela mesma não sabia o que era, estando em lugar nenhum. Aquele choro repentino, sem motivo aparente, que interrompia a janta. Tão aflitivo que nem a fala: uma choro engasgado, sem lágrimas. Por dentro não só a sua língua, toda ela gaguejava. (DOURADO, 1999c, p. 152)

Na casa de vovô Tomé, João se sentava ao lado de tia Margarida na mesa e se dividia entre ler e observar atenciosamente os seus gestos, sobretudo quando ela jogava paciência e um meio sorriso aparecia. Essa estranheza passou a incomodá-lo.

Às vezes ele sentia uma ansiedade muito forte, um temor surdo de que ela pudesse completar uma fileira sem se voltar e sorrir. Era uma sensação estranha de morte, como se ele só existisse naqueles breves instantes, como se ele não existisse, sendo apenas uma figura esfumada no sonho de tia Margarida: ela podia acordar de repente e ele estaria morto. Todo o pensamento de João era feito de magia e medo. (DOURADO, 1999c, p. 153) 
Com "o pensamento afogado em angústias terríveis, em abismos de medo", João não parava de olhar, mergulhava "na aflição daquela luta sigilosa." (DOURADO, 1999c, p. 154). Parece que se entendiam naquela "muda comunicação."

Seja no modo de se vestir, jogando paciência ou lendo os mesmos livros, João observava que tia Margarida não queria abandonar um mundo regido pela ordem, por uma imaginação formal, por uma lógica da identidade. $\mathrm{O}$ eu da tia só se encaixava num mundo petrificado pela razão, fechado. Não se abria para a convivência com o outro eu, outro ser. A diferença a angustiava.

Quando tia Margarida não estava jogando, lia. Não eram muitos os livros, uns dois ou três. Mas, encapados com papel azul, João tinha a impressão de que lia sempre o mesmo livro. Parece que ela tinha medo de sair de um mundo que conhecia de cor e salteado. (DOURADO, 1999c, p. 155)

Na casa de vovô Tomé, mostrava João que a paradeza do ser se repetia. Vovó Naninha no crochê, vovô Tomé na rua, tia Margarida no jogo. Segundo a hermenêutica da imaginação material e dinâmica de Gaston Bachelard, em A Poética do Espaço: "A imagem da casa se torna a topografia do nosso ser íntimo. [...] Nossa alma é uma morada." (BACHELARD, 1989a, p. 20). A casa é o símbolo não só do ser que se oculta, mas também do ser que se desoculta. A casa é o correlato objetivo da alma. A forma do habitar a casa implica a vida ou a morte da alma. Esse é o caso específico de tia Margarida. A imagem da casa assim como a imagem da água correspondem à dialética, hesitação ou inquietação do ser. Nesse horizonte, verifica-se em $O$ Risco do Bordado, a partir das refletorizações do personagem-metáfora João, a presença de uma fenomenologia da imaginação poética cuja tarefa consiste em "apreender o ser efêmero" e mostrar que "o homem é o ser entreaberto" (BACHELARD, 1989a, p. 221 e 225).

Nas investigações de João, a casa da alma de tia Margarida se apresentava como "imobilidade", "ausentar-se do mundo", "paradeza de águas mortas". Isso provocava no refletor uma "sensação de morte, medo sufocante". 
Terror e angústia, as emoções dramáticas que atingem o leitor também. Nesse ponto da narrativa, começamos a conhecer e presenciar aquilo que primeiro aconteceu e que é o motivo dessas lembranças labirínticas, revividas e reinventadas de João.

Para vencer a angústia e trazê-la de volta ao próprio corpo, ele foi se chegando para junto dela, o joelho procurava alcançar a dureza do corpo. Devagarzinho, cuidadosamente. [...] Foi se chegando, encontrou finalmente a coxa de tia Margarida. Ela não se mexeu nem um pouco, parecia não reparar. Devia estar mesmo muito longe, custava a voltar. (DOURADO, 1999c, p. 157)

Num movimento verticalizante, o ser aéreo e ausente de tia Margarida vai se tornando terrestre e presente. Epifanicamente, materializam-se os sentidos. Os olhos da alma voltam a se integrar aos olhos do corpo.

\begin{abstract}
Ele sentiu de repente ela voltando. O latejar da carne, o repelão estremecendo todo o corpo. [...] Os olhos afogados no vazio foram ganhando brilho, um movimento manso, as pálpebras se mexiam, as pestanas piscavam. Ela cerrou os olhos e ficou respirando fundo, o peito subindo e descendo, as narinas se abrindo e fechando. Tomava posse do corpo, procurava se acostumar.

Depois ela foi abrindo os olhos. A princípio assustados, os olhos miravam as coisas como se vissem pela primeira vez. As coisas tinham uma vida silente e brilhosa, nunca antes reparada. Vindo de longes paragens, ela procurava se acostumar ao mudo e às coisas em redor. (DOURADO, 1999c, p. 158)
\end{abstract}

Uma cosmogonia implicando uma antropogonia, uma passagem do reino da morte ao reino da vida corpejante. As cenas do refletor mostram-nos o movimento de oscilação do ser, interação recíproca da alma e do corpo em tia Margarida

Ao mesmo tempo, o próprio personagem-metáfora João sofre a hesitação desses extremos contrapolares. Entre realidade e imaginação, certeza e incerteza, a experiência dupla e simultânea de prazer e dor.

Aliviado mas ainda sob a magia daqueles olhos, João se esquecera de retirar o joelho. Percebeu que estava assim há muito tempo. Ela devia estar sentindo a pressão na coxa mas não se afastava. A fim de tirar a prova, calcou mais. Ela não se afasta, ao contrário - pressiona um pouco. Ele sente o calor da coxa, o corpo vivo e quente, súbito vivo demais. O coração descompassa, sufocado em ondas quentes, 
ele mal podia respirar. Se contrai, fecha os olhos para só viver o quentume, a contração dentro do peito.

Será que aquilo estava mesmo acontecendo? Ele agora se entregava às sensações mais quentes, um prazer violento lhe estremeceu 0 coração. Será que percebia? Ela estava em si, será que tinha mesmo voltado? Não podia haver dúvida, pelo calor da coxa passando para ele. Queria ter a certeza de que ela estava percebendo, participava. Tinha medo de que tudo acabasse de repente. Bom e temeroso demais. Todo ele tremia, vibrava interiormente. (DOURADO, 1999c, p. 158)

Na prosa epifânica e labiríntica de O Risco do Bordado, estruturada na recorrência incessante de silêncios e palavras, metáforas e montagens, dos dramas personativos familiares e estranhos, as imagens de tia Margarida se fundem dramaticamente, na consciência rememorativa de João, com as imagens da mãe e de Teresinha Virado, envolvendo-o num sentimento paradoxal de prazer e culpa trágica.

Ela estava percebendo? Queria ter a certeza. O prazer seria maior, o
gozo mais fundo. Prazer e sensação difusa de pecado. Um roupão,
um corpo branco molhado. Mistura de cheiros. Alfazema, água-de-
colônia, Leite de Rosas. Cheiro quente, grosso, oleoso, penetrante.
Cabelos pingando água, seios que eram duas verrumas de dor,
ventre túmido. Corpo branco, recendendo. Cheiro estridente. Roupão
solto sobre os ombros, nudez que ele menino de repente
surpreendeu. (DOURADO, 1999c, p. 158-159)

Neste desregramento de todos os sentidos, sugerido pelo rigor da construção autraniana de $O$ Risco do Bordado, a refletorização de João insere o leitor nos processos de compreensão dos caminhos labirínticos da alma. No velar e desvelar das lembranças, vão se formando e transformando o bordado (texto) e o risco (palimpsesto) da escrita e da existência de João. As epifanias dionisíacas da narrativa da memória reúnem corpo e alma, exterioridade e interioridade, ser e não-ser, vida e morte, tempo e espaço, imaginação e realidade. No acontecimento da experiência de João e tia Margarida, a fusão do sagrado e do profano, da mãe e de Teresinha Virado, do outrora e do agora, do prazer e da dor, do menino e do adolescente.

Aquele corpo branco e nu ressuscitava das sombras, vinha dos confins do tempo. O corpo molhado, dolorosamente branco. O roupão apenas sobre os ombros. O cheiro de carne: quente, oleoso. Mistura de Leite de Rosas e água-de-colônia. Aquele outro roupão envolvia o corpo pecaminoso de Teresinha Virado, no bordel da Casa da Ponte. 
Teresinha Virado vinha de roupão vermelho, não era de ramagens como ele sonhava...

$\mathrm{E}$ de repente, quase no desmaio da dor, aqueles dois roupões se abriam, as duas mulheres se fundiam numa só. Num só medo, num só remorso, numa só dor. Era a mãe no roupão de ramagens de Teresinha Virado, a Casa da Ponte. A mãe saindo do banho diante dos olhos do menino assustado. Na sístole da dor, era miúdo demais, cabia na concha da mão o coração do menino. (DOURADO, 1999c, p. 159)

Uma pessoa em duas, duas pessoas em uma. Texto e personagem, tempo e memória: metáforas do ser que se encobre e se desencobre. Vale ressaltar que as imagens que se apresentam nas visões de João não são meramente objetos contrapostos a um sujeito. Não há aqui uma visão científica, mas uma visão poética integradora dos sentidos do mundo. A memória da narrativa não é a dos fatos passados, mas a dos acontecimentos poéticos do ser que não cessa de produzir efeitos na vida presente. Como nos diz Gaston Bachelard, em A Poética do Espaço:

É no plano do devaneio, e não no plano dos fatos, que a infância permanece em nós viva e poeticamente útil. Por essa infância permanente, preservamos a poesia do passado. Habitar oniricamente a casa natal é mais que habitá-la pela lembrança; é viver na casa desaparecida tal como ali sonhamos um dia. (BACHELARD, 1989a, p. 35)

No instante do acontecimento entre João e tia Margarida, emergem os impulsos de atração e repulsão.

\begin{abstract}
Esperava que ela procurasse o seu joelho afastado mas que alcançaria sem grande esforço. Mas ela não vem. Como ela não vem, lentamente vai se aproximando dela. Tocou-a, sente o calor que dela irradia. Ela devia se afastar. Mas ela não se afasta. Pressiona o joelho, agora a coxa inteira.

Não podia ser engano, ela tinha consciência do que estava fazendo. Mas dentro dele o medo e a dúvida ainda persistiam. [...] Afastou o joelho, ela é que devia procurá-lo. Não podia sofrer sozinho, precisava dividir a culpa, aliviar o peso no coração. (DOURADO, 1999c, p. 160)
\end{abstract}

Por fim, a confirmação do encontro silencioso e ruidoso dos sentidos, a transgressão dionisíaca da ordem, marcando a existência solitária dos dois. A fusão de corpo e alma traduz o sentimento simultâneo de amor e morte. 
Num átimo durou demais aquela dúvida, aquela espera. Como ele não vem ao seu encontro, ela pára. Para depois voltar. Desta vez de outra maneira. Não podia haver nenhuma dúvida: ela sabia o que estava fazendo, e queria. E ele sentiu, ouviu mesmo o pé se arrastando debaixo da mesa: a gastura da sola nas tábuas do assoalho seco. O pé procurando. Não se afastou, deixou que ela o encontrasse. E como ela o encontrou, ele se aproxima mais. Deixa que os pés, as pernas, as coxas se encostem. Os dois corpos se fundiam num só quentume, no mesmo cheiro e calor. (DOURADO, 1999c, p. 160)

Nesse jogo da memória, o refletor João nos lembra que os dois posteriormente se comportaram como se nada tivesse acontecido, e, por isso, um sempre fugia do outro. Ambos viram e sentiram, por trás do rosto externo, o abismo terrível e tenebroso de si mesmos e do mundo. $\mathrm{O}$ acontecer do ser e o acontecer do nada são um e o mesmo. Esse acontecimento entre João e tia Margarida lembra ou espelha o outro acontecimento entre João e Valente Valentina, no terceiro bloco narrativo. Na estrutura narrativa recorrente de $O$ Risco do Bordado, a história subliminar do texto, do ser e da vida é a experiência do palimpsesto, do nada e da morte.

\footnotetext{
Parecia que ela desejava deixar em João a mesma incerteza, de maneira que ele não pudesse nunca saber se alguma coisa realmente aconteceu, se apenas imaginou, se tinha sonhado.

E assim nada acontecia, aquilo não mais se repetiu. No silêncio de cada um, sem mesmo a troca de um simples olhar, a palavra não sendo jamais possível, eles fizeram um trato escondido que haveriam de sempre obedecer.

[...] Quando acontecia se encontrarem sozinhos na sala, na cozinha, na horta, um fugia do outro como se fugisse de uma culpa que se quer esquecida, um pecado terrível que os dois apenas começaram, jamais teriam ousado cometer. (DOURADO, 1999c, p. 161-162)
}

A narrativa dramática, mito-poética e dionisíaca de O Risco do Bordado estrutura-se, em seus sete blocos narrativos, como movimento lúdico e labiríntico da memória do ser no tempo. O Salto do Touro é a chave hermenêutica que desvela a trama da morte como matriz estrutural que correlaciona a unidade e a diversidade dos blocos narrativos. O mito do Tempo, a criança divina e dionisíaca que ressurge de sua própria morte, o ser trágico da própria realidade do homem e do mundo, eis a memória que se desvela nas metamorfoses do narrador personativo e do personagem-refletormetáfora João. Portanto, o jogo como símbolo do mundo é a escrita da morte em O Risco do Bordado. 
Após esse acontecimento, João retorna ao colégio em São Mateus. Como vimos, por um lado, a sua aprendizagem ou formação se processa, sensivelmente, entre os habitantes e familiares em Duas Pontes (Teresinha Virado, tio Maximino, Valente Valentina, tio Zózimo, vovô Tomé, tia Margarida e Xambá); e, por outro lado, inteligivelmente, entre os professores, os colegas e o diretor do colégio interno em São Mateus. João realiza, fundamentalmente, duas viagens em todas as idas e vindas de Duas Pontes a São Mateus, ou seja, a viagem da experiência passional e a viagem da ciência racional. Em ambas as viagens não estão em jogo simplesmente os fatos, mas os efeitos que provocam na mundividência ou formação existencial de João. As lições do viver e do escrever, em Duas Pontes e São Mateus, são textos que não são lidos literalmente nem aceitos resignadamente por João.

Por isso, as suas reflexões destacam os efeitos da passagem do tempo nos outros, em si mesmo e no próprio processo de compreensão do ser. Não uma cronologia, mas uma ontologia do tempo, eis o que se manifesta em $O$ Risco do Bordado. Como os personagens reagem diante da experiência física e espiritual do tempo, ou seja, da finitude do ser e do conhecer, é o que se encena diversa e dramaticamente nos sete blocos narrativos da obra autraniana. Em todos eles a morte é a protagonista e os personagens correspondem aos seus efeitos. Alguns não suportam o embate e autosacrificam-se deliberadamente como tio Zózimo e o bisavô Zé Mariano, mas todos, inegavelmente, experimentam, na carne e no espírito, as marcas profundas do tempo. Todos revivem e recordam o tempo da infância como vovô Tomé no circo, vovó Naninha e tio Zózimo, tio Zózimo e tio Alfredo.

A aversão à passagem do tempo implica a sua experiência, mas não a sua aceitação. Muitos se conformam à morte petrificada na forma dos valores estabelecidos religiosa, social, familiar e linguisticamente. Mas, como veremos, só o refletor João transcende essa situação ao educar-se artisticamente. Os outros morrem e sucumbem paralisados porque fogem à compreensão do tempo. Já o personagem-metáfora João morre e devém, ou seja, compreende a abissalidade da existência e ressurge dionisiacamente, alterando-se, 
reinventando-se. Ele é o poeta da vida que não renega a sua própria finitude, mas escreve-a no corpo e na alma. Artisticamente aprende e compreende o eterno ser, despersonaliza-se, metamorfoseia-se. João é a metáfora do eterno ser, e não a certeza do ser eterno. Não é o humano demasiado humano que se escraviza ou se petrifica, mas o transumano, o homem novo, o que se põe em travessia diante da força implacável do horizonte móvel do tempo. Somente escrevendo a morte em si mesmo, é possível ser outro. O ser não é, devém incessantemente.

Voltando a São Mateus, à vida selvagem no colégio, João vai experimentando a passagem vertiginosa do tempo. O menino crescia, desaparecia, dando lugar ao homem. O menino ia sendo "engolido pela voracidade do tempo, enterrado nas brumas" (DOURADO, 1999c, p. 162).

Ele viajava, ia e voltava. la e voltava, viajava no espaço e no tempo. O menino ficando cada vez mais longe, ele passando esfuminho, esbatendo o desenho na folha de papel. Tudo corria numa velocidade vertiginosa, o coração miúdo de avelã, num instante era Natal. (DOURADO, 1999c, p. 162)

O tempo é o labirinto da alma ou a recordação que João percorre em busca de si mesmo, daquele menino na plataforma da estação da vida que "ia ficando para trás, cada vez mais distante na paisagem, na noite, na memória. Apenas uma sombra, um ponto, mais nada." (DOURADO, 1999c, p. 163)

O narrador personativo assinala que as mudanças físicas (pêlo, espinha, barba, nariz, olhos, voz) provocavam velozes mudanças internas no rapaz. Nesse ritual de passagem, a morte do menino gerava dolorosamente a vida do adulto. Nessa transição, João era "um dos sete jovens que seriam sacrificados pelo touro no labirinto." (DOURADO, 1999c, p. 164). Nessa referência mitológica do narrador, temos uma metalinguagem acerca da própria estrutura de composição de O Risco do Bordado: mítica, labiríntica, em sete blocos narrativos, regida pela trama da morte, o touro como metamorfose ou epifania dionisíaca da vida que se devora, que se sacrifica, que se alimenta da própria morte. O labirinto do tempo que envolve a todos nos seus misteriosos 
caminhos, que nos faz pressentir que o inesperado da morte também é esperado (Heráclito, fr. 18).

As palavras de Autran Dourado, no texto "Uma segunda ordem de leitura", presente em Uma Poética de Romance: Matéria de Carpintaria, esclarecem-nos a importância central desse sexto bloco narrativo, O Salto do Touro, para a compreensão hermenêutica de O Risco do Bordado, pois desde o título

funde as várias imagens e símbolos, distribuídos ritmicamente por todo o livro, sobre touro, sangue, sacrifício, Minotauro, labirinto e memória, Cronos, as raízes mais fundas do mito grego e univeral. [...] O Salto do Touro é o nome de um mural existente no Palácio de Cnossos, sobre o Minotauro. (DOURADO, 2000a, p. 49)

$\mathrm{Na}$ vida selvagem do colégio, o mundo lírico da infância ia sendo apagado da lembrança, sacrificado.

De dia era fácil não se lembrar daquele menino, esquecia-o inteiramentente. A algazarra, a violência, a selvageria do internato abafava o menino. O menino delicado e sensível que ele tinha sido, ali não podia viver. (DOURADO, 1999c, p. 164)

Mas, à noite, no silêncio e na escuridão do dormitório, entre o sono e 0 sonho, para além de seu atual e rude corpo, o menino dionisíaco renascia nas lembranças de João.

No escuro não podia ver, apalpar não adiantava, os sinais da sua grossura e dureza, ele se transformava recuando no tempo, voltava a ser 0 antigo menino. E a presença daquele menino dentro dele impedia-o de dormir, não encontrava cômodo para o corpo cansado e aceso. Não era o menino que ele queria esquecer e sepultar, mas as lembranças que vinham com ele. (DOURADO, 1999c, p. 164)

Proustianamente, o tempo e o mundo perdidos da infância retornam, da escuridão se iluminam desejos, medos e culpas, dos fragmentos a cena inteira. $\mathrm{Na}$ recordação, o passado vem alterado pelas experiências sensíveis. A memória não é a reprodução, mas a imaginação criadora do passado, do presente e do futuro. 
E tudo (qualquer coisinha de nada, um cheiro, uma cor, um fiapo de imagem) Ihe restituía os dias antigos, as coisas passadas não como realmente tinham acontecido mas acrescentadas, escurecidas, umedecidas, contaminadas por outras lembranças, envenenadas de pecados e sombras durante os dias, os meses e anos que passaram mergulhadas nas águas lodosas do tempo, escondidas nos subterrâneos da memória. E ele não podia deter o rolar sufocante, as águas negras da angústia. (DOURADO, 1999c, p. 164)

Como nos lembra o crítico Hans Meyerhoff, em sua obra O Tempo na Literatura (1976), a técnica associativa do "fluxo de consciência" na literatura moderna estabelece a correspondência ou unidade do tempo e do eu como símbolo do rio que continuamente rola e altera suas águas. $\mathrm{O}$ eu não é uma substância no tempo, mas uma contínua deveniência. É o "mesmo" que incessantemente se transforma em "outro". As associações livres presentes nos devaneios e fantasias do indivíduo são aparentemente caóticas, mas, na verdade, "são sempre selecionadas, controladas e organizadas pelo autor a fim de conseguir o efeito de continuidade e estrutura." (MEYERHOFF, 1976, p. 35). Nas narrativas modernas de Marcel Proust (Em Busca do Tempo Perdido), James Joyce (Ulisses) e Virgínia Woolf (Mrs. Dalloway), afirma o eminente crítico, a continuidade e unidade do tempo e do eu é o reconhecimento de que, nas lembranças de experiências isoladas, únicas e irrepetíveis, a memória não é um hábito, mas uma "imaginação criadora".

A imaginação criadora é recordação criadora. A recordação é uma atividade, uma operação - não a reprodução passiva das respostas habituais da memória. Construir uma obra de arte é reconstruir o mundo da experiência e do eu. (MEYERHOFF, 1976, p. 43)

Assim, o que o refletor João busca recuperar nas suas memórias equivale à busca proustiana de transformar o tempo perdido no tempo recuperado, o eu perdido no eu reinventado. A escrita ou recordação da morte é a possibilidade de configurar a vida como obra de arte, reinvenção de si mesmo e do mundo. A vida ressurgindo das cinzas das horas, eis a narrativa mítica e dionisíaca da memória em O Risco do Bordado.

No escuro do dormitório e de si mesmo, nas águas lodosas do tempo e nos subterrâneos da memória, o refletor João vai integrando as imagens de Teresinha Virado, de sua mãe e de tia Margarida. Além de uma das sete 
vítimas sacrificadas, João vai se tornando também o próprio Minotauro nos labirintos da memória.

Se não era possível substituir a imagem nua e dolorosa da mãe nem pelo mito nem pela lembrança real de Teresinha Virado, aceitava como um castigo inevitável, um pecado menor, a lembrança daquela noite na casa de vovô Tomé. $E$ todo ele se entregara às mais quentes sensações, deixava-se fundir na carne ardente, no quentume cheiroso, na respiração de tia Margarida.

$\mathrm{Na}$ lógica terrível dos sonhos ele se salvava e se perdia: era não apenas um dos sete jovens sacrificados pelo touro mas o próprio Minotauro, um touro virgem que mugia solitário no seu negro e sanguinolento labirinto. (DOURADO, 1999c, p. 166)

Nas palavras concisas do eminente crítico Fábio Lucas, em seu ensaio "O sete-estrelo de Autran Dourado", encontramos a verdade dramática que emerge como o risco do bordado da memória de João e da própria obra de arte de Autran Dourado.

E, por detrás da infância, da juventude e do relato das coisas passadas, oferecidas sob a forma de paixão e urdidas para despertar espanto, o que iremos encontrar é a noção revigorada da irreversibilidade da vida e a consciência esmagadora da morte. (LUCAS, 1973, p. 142)

Do sonho em São Mateus à realidade em Duas Pontes, o refletor João retorna outra vez à casa de vovô Tomé. Sente mais ainda a distância temporal e a metamorfose existencial que o separam do amigo Zito.

\begin{abstract}
Zito ficou homem mais cedo do que ele. Um homem apagado, comum demais, sem nenhum interesse. Estava agora de uma semgraceza! Gostava de se lembrar de Zito era quando os dois eram meninos. Os passeios pela cidade, pelos matos. O besta do Tuim sempre rabeando, menino tinhoso. Quando viviam o mito do capanga, dos bandidos, de Xambá. O cavalo de Buck Jones se confundia com o Jaú, montaria de Xambá. Os tiros e relâmpagos. As mortes contadas. Quando os dois inventavam a mulher. Aquela vez que foram juntos à Casa da Ponte. Quando aquela vez Teresinha Virado de roupão. (DOURADO, 1999c, p. 167)
\end{abstract}

Mas, sobretudo, numa noite fria, sente compaixão por vovô Tomé em suas experiências de vida repletas de agonia e morte. Imagina-se um dia como escritor da própria narrativa dramática de sua família. Como escritor que transfigura a morte na consagração da infância da vida. 
Coitado de vovô Tomé, tanto sofrimento na vida. Depois que tio Zózimo morreu ele tinha perdido muito, parecia bem mais velho do que era, estava acabado. Os seus compridos silêncios. Os olhos tristes, parados e perdidos, boiando nas cinzas do tempo. Um rio escuro corria debaixo da ponte de vovô Tomé. Vovô Tomé, aquela confissão que lhe fez um dia. O bisavô Zé Mariano, vovô Tomé e o irmão natural, seu Teodomiro. Um dia gostaria de ser capaz de escrever todas as histórias de sua família. Os casos que ele tinha vivido, os que apenas presenciou, os que ouvira contar. Os casos que ele mesmo inventara, e não sabia mais se tinham ou não acontecido. Para que o mundo de sua infância não ficasse soterrado. Para que tudo - vivências, sensações, lembranças - não se perdesse deglutido pela fome do tempo. (DOURADO, 1999c, p. 167-168)

Nesta passagem, como num projeto ou reflexo em miniatura, estamos diante da inteireza da própria obra O Risco do Bordado. Esse futuro é o próprio presente e o próprio passado da narrativa que estamos lendo. Todos os sete blocos narrativos representam o mito e a realidade deste momento. Como a vítima e o próprio Minotauro no labirinto, o personagem-refletor, o leitor e o narrador personativo são um e o mesmo na estrutura labiríntica de $O$ Risco do Bordado. A morte ou a ferocidade do tempo é a protagonista que persegue a todos na escrita e na leitura, no mito e na realidade dos planos da enunciação e do enunciado da obra autraniana.

Na equivalência da noite no internato e da noite na casa de vovô Tomé, na noite do tempo antigo, o refletor João sonha novamente aqui.

Deitado no escuro, um outro João parecia nascer de dentro dele. Um João que ele vinha tentando afogar na memória, enterrar na paradeza do tempo, desde aquela sua primeira noite no internato.

Mergulhado nas névoas da lembrança, na imensidão infinita do tempo, na mornidão opaca, na modorra das horas, ele neutro e silencioso, só então reparou que o quarto estava embaciado, o ar pesado demais. (DOURADO, 1999c, p. 168)

$\mathrm{Na}$ noite do mundo e de si mesmo, experimenta a abissalidade e a solidão a que todos estamos unidos.

Naquela imensidão de noite estrelada, inundado pela luz alvacenta do luar, gostaria de descansar o coração na mão espalmada de Deus, dissolver-se na luz distante, parada, fria, serena (tudo envolvia a doce brisa macia), serena e eterna de Deus. Aquele Deus de sua infância, que ele agora, na sua desesperada suficiência, na sua insegura e violenta certeza, na sua angústia de viver, na sua busca, na sua sede nunca satisfeita, na sua fome brutal, entre lágrimas palmilhando o 
caminho da dor, do deserto, procurava negar. (DOURADO, 1999c, p. 169)

Nessas reflexões, acaba reparando que havia luz no quarto de tia Margarida, que ela também estava acordada. Foi então que "alguma coisa cantou forte dentro dele". Lembrou-se daquele acontecimento com tia Margarida na mesa da sala. Não conseguia refrear o desejo. Epifanicamente explodiam os sentidos: "E de repente um touro feroz acordou dentro dele. Agora era só narinas respirando apressado. Um touro de chifres vermelhos, saltando, mugindo no labirinto escuro, sanguinolento." (DOURADO,1999c, p. 170)

Apagou a luz do quarto e pulou a janela. Escondido, encostando-se no tronco da mangueira, observava tia Margarida: "Paralisado, trêmulo, alguma coisa devia acontecer." Nesse drama estático, experimenta o inesperado. Vê, inicialmente, outra tia Margarida renascendo e brilhando como uma deusa.

Súbito viu: tia Margarida apareceu no quadro iluminado da janela. A
camisola de rendas abotoada até o pescoço, as mangas compridas.
Toda branca, ela parecia mais branca do que realmente era. Os
cabelos compridos, soltos e pretos, lustrosos, brilhavam, caindo em
ondas sobre os ombros. Ele fascinado pela aparição diáfana e
branca. Ela parecia envolta num halo de luz, uma luz que irradiava
dela mesma. Linda, ele achava-a linda. Os olhos enormes, havia nela
alguma coisa estranha e misteriosa. Andava lentamente, descalça
certamente. Era como uma figura nascida do fundo da noite, que
vinha varando as névoas do sonho. Irreal, como uma Verônica de
cabelos soltos numa procissão noturna. Só que ela estava de branco,
a cabeça descoberta. [...]
Fascinado pela aparição, se esquecia de tudo. [...] E de novo viu que
ela era linda, assim de cabelos soltos. Muito mais nova do que na
verdade era. (DOURADO, 1999c, p. 171-172)

E, logo em seguida, a surpresa maior. Da prisão do ser, tia Margarida libertava-se em toda a sua sensualidade. No refletor João, ocorre a fusão e a impressão novamente das imagens de Teresinha Virado e da mãe agora na realidade visível da corporalidade de tia Margarida. Espantosamente, o acontecimento antes só imaginado. Na interioridade do refletor, a vida explodia como a morte, o desejo como a dor. O narrador personativo arma para o leitor a arquitetura caótica do desregramento dos sentidos do refletor. 
Quando aconteceu. Aconteceu que ela, antes letárgica, começou a se mover. E foi desabotoando a camisola em gestos suavíssimos: primeiro os punhos, depois a gola, o trespasse. Ele fechou os olhos, com medo de ver. Queria ser surpreendido pela visão com que sempre sonhou, que sempre temia. As ramagens de um roupão de cetim, um roupão vermelho, as chinelinhas cor-de-rosa, os cabelos pingando água do banho. Uma dor verrumava fundo, varando. Tinha medo de abrir os olhos e ver. Os olhos fechados, dentro dele espocavam gritos, foguetes na escuridão. Eram palavras gritadas por bocas vermelhas, de dentro de negros labirintos. Nudez, mistério, brancura, morte! Êxtase, transe, fascínio, agonia, ressurreição! Todo ele eletrizado, à espera de morrer. (DOURADO, 1999c, p. 172)

As impressões do refletor agora de olhos abertos indagam para quem tia Margarida realizava aquele desnudamento do ser, aquele ritual, feito uma bacante a se entregar ao sacrifício. Presencia-se um verdadeiro eros cosmogônico, um casamento do corpo e do espírito, do amor e da morte, do humano e do divino.

Quando abriu os olhos viu que ela, na brancura de sua nudez, explodia toda em luz, luar. Toda ela nudez e luz: diáfana, pura, leitosa. Ela podia morrer agora, morreria no seu mais alto momento de luz e glória. A nudez que via era maior do que toda a nudez que sonhara.

Os braços abertos, a cabeça erguida, ela se dava em espetáculo e agonia. Para quem aquela liturgia de luz e nudez? Aqueles passos que agora eram dança? Os passos da pura música não eram para ele nem para ninguém. Para um deus desconhecido que mora na lua talvez.

Era para a lua que agora dançava, oferecendo os seios brancos e luminosos, o ventre redondo, as coxas firmes e arqueadas, toda ela um arco na mão do deus. O corpo esticado em arco, segurava os seios como se desse leite a alguém. Toda ela um só estremecimento, um só estertor. Feito em gozo, os olhos fechados, parecia balbuciar. Como se estivesse sendo possuída, flechada. Ela podia desmaiar naquele paroxismo, podia mesmo naquele sacrifício morrer. (DOURADO, 1999c, p. 172-173)

Assim, o personagem-refletor é atingido pelas emoções dramáticas de aflição e terror, atração e repulsão. $O$ seu drama é estático, não é cinético. $O$ drama é de paixão, não é de ação: "Ele sentia um medo tão forte, um estremecimento tão grande, uma dor tão funda, que cuidou também não resistir." (DOURADO, 1999c, p. 173). Mas, de repente, todo o momento se desintegra na passagem recíproca da interioridade à exterioridade. Na visão dos dois, o ser se desfazendo em nada. Movimento e paralisia atingem ambos. A verdade se desnuda novamente como aflição e terror. 
Foi quando, sem perceber, avançou. Os pés bateram numa pedra, caiu. O barulho que fez, ela ouviu. Viu-o. Na cara, nada - o terror branco. Sem poder se afastar, a boca aberta com que procurava articular um grito: ele cuidou ouvir, ela na verdade não gritou. Não se afastou nem se cobriu. Quem teve de fugir foi ele, como se ele é que estivesse nu. (DOURADO, 1999c, p. 173)

$\mathrm{Na}$ narrativa autraniana, as cenas saltam no tempo e no espaço, provocando rupturas na estrutura e na leitura dos blocos narrativos. A estrutura aberta e vertical de $O$ Risco do Bordado incorpora os silêncios entre os personagens e os episódios, o narrador e o refletor, as palavras e as coisas.

Nessas viagens no tempo e no espaço, no interior e no exterior, na alma e no corpo, João mais uma vez voltava de São Mateus a Duas Pontes. Havia se passado muito tempo depois daquele último acontecimento com tia Margarida. João inventariava na memória a primeira viagem que fizera de casa para o colégio. Olhando para o passado distante, reconhecia a própria alteridade, o ser se dissolvendo em não-ser:

Aquele primeiro dia era uma coisa tão antiga, tinha ficado tão para trás que era como se tivesse se passado não com ele mas com outro menino, um menino agora morto e enterrado no tempo. (DOURADO, 1999c, p. 174)

João reflete mais uma vez acerca das questões do ser e do tempo, da identidade e da alteridade. $\mathrm{O}$ tempo e o eu como um rio corrente. $\mathrm{O}$ símbolo do rio como metamorfose da natureza e da natureza humana pode-se encontrar no pensamento poético de Heráclito (séc. VI a. C.).

Para os que entram nos mesmos rios, afluem sempre outras águas; mas do úmido exalam também os vapores. (Fr. 12)

No mesmo rio entramos e não entramos; somos e não somos. (Fr. 49a)

Não se pode entrar duas vezes no mesmo rio. (Fr. 83)

(ANAXIMANDRO, PARMÊNIDES, HERÁCLITO, 1991, p. 61, 71 e 83 , respectivamente.)

O tempo e o rio. O tempo e o eu. Nesse símbolo da insubstancialidade do ser, do mundo e do homem, encontramos a própria representação da criança divina e dionisíaca. Nas palavras de Heráclito, o obscuro: "O tempo é 
uma criança, criando, jogando o jogo de pedras; vigência da criança." (ANAXIMANDRO, PARMÊNIDES, HERÁCLITO, 1991, fr. 52, p. 73)

João se indaga pelo menino antigo, busca a origem do tempo perdido e redescoberto. Reinventa a si mesmo no horizonte móvel do tempo. Conforme as palavras de Heráclito: "Eu me busco a mim mesmo." (ANAXIMANDRO, PARMÊNIDES, HERÁCLITO, 1991, fr. 101, p. 85). Essa é a busca ontológica do personagem-metáfora João que se desvela em todos os blocos narrativos. A busca da identidade é, por conseguinte, a experiência da própria alteridade do ser e do mundo.

Ao recordar-se da primeira viagem ao colégio interno em São Mateus, o refletor João nos fala do menino antigo que, cheio de medo, declinou ao diretor do colégio a sua identidade: João da Fonseca Nogueira.

\begin{abstract}
Identidade a que ele procuraria se adaptar a vida inteira. [...], na sua busca incessante de uma figura que ele ia montando com a paciência de um relojoeiro, uma imagem a que ele procurava amoldar a própria alma ainda naquele tempo sanguinolenta da placenta do antigo menino. (DOURADO, 1999c, p. 174)
\end{abstract}

A visão, a verdade e o tempo se integram nas reflexões de João: "As coisas mudaram tanto, fazia tanto tempo, ele era tão outro." (DOURADO, 1999c, p. 174). Assustava-se, quando, depois das muitas viagens de Duas Pontes a São Mateus e vice-versa, olhava as marcas da velhice em si mesmo, na mãe, no pai, na vovó Naninha, no vovô Tomé. E meditava sobre as várias qualidades do tempo que abarca tanto a natureza humana quanto a natureza: o tempo presente (dos outros), o tempo passado (de si mesmo) e o tempo das montanhas e das coisas inanimadas (para nós), "móveis e fluidas diante da eternidade, o sem-tempo de Deus" (DOURADO, 1999c, p. 175). E o narrador personativo ironicamente comenta as descobertas do refletor:

As próprias coisas mudavam, mesmo uma montanha - a coisa que ele podia imaginar de mais parada, na sua paradeza mudava, imperceptivelmente mas mudava. Mesmo que não se note, as coisas mudam, ele achava descobrindo verdade tão corriqueira. [...] Não importa que as mudanças tenham se passado num minuto, numa hora, num mês, num milhão de anos; o que importa é o milagre da mudança, dizia ele já naquela época fascinado pelo mistério do 
tempo, descobrindo o que outros antes dele já tinham descoberto e outros depois dele iriam descobrir, até a consumação dos séculos.

Aquilo não era novidade nenhuma, ele estava era descobrindo a pólvora. Como dizia aquele seu colega místico, é fechando os olhos que se vê Deus, é dentro do maior silêncio que se ouve a Sua voz, se lembrou. (DOURADO, 1999c, p. 175-176)

João notou também as mudanças temporais em tia Margarida depois daquele último acontecimento. Ela não ficava mais jogando paciência nem lendo os mesmos livros, agora toda noite pegava o véu e o livro de orações, ia para a reza. Mudava até na roupa, usando só preto, e não mais uma golinha de crochê branca. Parecia uma viúva. Envelhecida na figura, na voz e nos olhos.

A pedido de vovô Tomé, João não foi logo embora de Duas Pontes. Aguardou até a Semana Santa. A procissão passaria pela porta da casa de vovô Tomé.

João foi para lá, queria ver se alguma coisa tinha mudado desde os seus tempos de menino. Quando menino, além das matracas, do que ele mais gostava era quando a Verônica subia numa cadeira e cantava em trenos profundíssimos, desenrolando vagarosamente 0 lenço que ela mostrava para a multidão contrita ajoelhada a seus pés. (DOURADO, 1999c, p. 178)

Mas a Verônica não cantou perto da casa de vovô Tomé, que a viu passar "de cabeça baixa, os passos medidos, num silêncio de morte". Ao contrário do que o menino antigo esperava e mais gostava, o que o refletor João e o vovô Tomé presenciaram, diante da casa, surgindo da massa compacta de gente, do "rabo confuso da procissão", foi algo assustador e terrível. Tia Margarida exibia-se em público, condenava a si mesma, amortalhando e acorrentando o corpo que outrora consagrava a sua liberdade de ser diante dos olhos de João. Nessa outra Via Sacra, revela-se o retrato petrificado da própria dor humana diante da mortalidade terrestre.

E João viu, vovô Tomé viu. No meio do claro aberto, viram tia Margarida. $O$ vestido comprido como uma mortalha, roxo da cabeça aos pés. A cabeça baixa, os olhos postos no chão. Os pés descalços, sujos e feridos, em que ela prendera duas grossas correntes que ia arrastando penosamente. (DOURADO, 1999c, p. 179) 
Nas palavras de Friedrich Nietzsche, em sua obra Assim falou Zaratustra, ele se configura como a aversão da vontade ou o espírito da vingança contra a irreversibilidade do tempo: "Isto, e apenas isto, é a própria vingança: a aversão da vontade pelo tempo e seu 'Foi”' (NIETZSCHE, 2011b, Da redenção, p. 133). E essa mesma interpretação nietzschiana da vingança contra a fuga perpétua do tempo é corroborada pelo crítico Ronaldes de Melo e Souza, em seu importantíssimo texto "Agonia e morte em Autran Dourado":

\begin{abstract}
A repugnância da vontade em aceitar o duplo domínio da vida e da morte como dimensão específica da existência humana constitui 0 testemunho eloquente de que os personagens de Autran Dourado se rebelam contra o estatuto temporal. Sob o acicate da rebelião, substituem a roda da vida pela rota da morte. Na tentativa desesperada de sustar o tempo, apenas conseguem congelá-lo no passado, na direção unilateral que conduz tão-somente à morte. No ato titânico de negação do fluxo do tempo, assumem uma subsistência tartárica num estado plutônico-subterrâneo. Realizam uma ruptura retroativa no fluxo do tempo, que se consuma na desmesura trágica, mas também patética, de substituir a morte como fim da vida pela morte como princípio da vida. Não surpreende, portanto, que se nos apresentem como os que passaram, os que foram, os defuntos, enfim. (SOUZA, 2010, p. 164-165)
\end{abstract}

\title{
5.2.7. As Roupas do Homem ou O eterno retorno do ser
}

Este sétimo bloco narrativo, pertencente ao terceiro grupo (mítico), utiliza a técnica de ciranda, descritiva-narrativa, recorrente e se compõe de uma só narrativa que se abre e se multiplica em cinco pontos de vista diversos e contraditórios acerca do mito do jagunço Xambá, que povoou a infância do personagem-metáfora João. No texto "Narrativa em blocos e falsa pessoa", presente em Uma Poética de Romance: Matéria de Carpintaria, Autran Dourado afirma:

As Roupas do Homem é como que o meu Le Temps Retrouvé, dizem (aproximação que só me envaidece), em que tudo volta, todos os mitos dos demais episódios ou blocos da narrativa maior voltam e se explicam, enfim - uma ciranda. (DOURADO, 2000a, p. 24)

Portanto, o desnudamento ou desmitificação do homem ou arquétipo heroico Xambá, que símboliza todos os mitos que "tumultuaram e buliversaram a vida do menino" (DOURADO, 2000a, p. 50), a partir de cinco pontos de vista 
diferentes, longe de negar, confirma mais ainda a estrutura barroca, lúdica, labiríntica e aberta de composição de O Risco do Bordado, que promove incessantemente a interação da imaginação e da realidade, do ser e do nada, da vida e da morte. O perspectivismo narrativo de Autran Dourado representa, quixotescamente, a afirmação de que a realidade da ficção é a própria ficção da realidade.

\section{Estátua Eqüestre}

Nesta primeira versão do mito de Xambá, o narrador nos apresenta, inicialmente, a perspectiva da indeterminação coletiva ("a gente"), da coletividade que vivenciou aqueles "tempos heroicos" repletos das glórias de "cabras reisudos e machões". Logo, em seguida, vai nos revelando a perspectiva de João e, por fim, a de seu amigo Zito acerca de Xambá.

A chegada de Xambá a Duas Pontes é descrita na sua incerteza de origem: "vindo de um sertão muito longe: ora dizem que de Paracatu, ora das brenhas do Rio Doce." Xambá vivia nas memórias da comunidade, nos relatos orais de seus crimes, perversidades e vinganças "que a gente ia esquecendo nas brumas e nos sumidos das lembranças, dos ouvi-dizer, dos sussurros, dos casos acrescentados." (DOURADO, 1999c, p. 182)

Xambá era o "cometa da torvada infância de João." Sua fama de valentão e sua glória luminosa sempre retornavam ao imaginário do povo. As "ressonâncias estranhas" de seu nome faziam despertar a imaginação criadora com "histórias negras, arábicas e orientais." A sua descrição física tornava-o um ser "descomunal" e "desigual", dava-Ihe uma nobreza ímpar. A realidade quixotescamente virava um grande sonho.

Para João e os outros meninos, ter sangue de índio já era um começo de glória, um sinal de força, um certificado de coragem e valentia, arrogância e bravesa. [...] Assim os meninos (João, a gente) iam fantasiando, criavam um mundo de sonho em volta de Xambá: vivia-se um mito. (DOURADO, 1999c, p. 183) 
A lenda heroica de Xambá dizia que ele era muito ágil com o revólver e tinha um corpo fechado por artes diabólicas. O narrador destaca a sua singularidade aos olhos da comunidade: "Como também diziam que bala podia passar por ele, se alojar mesmo nos seus vazios, que Xambá não ia morrer de bala, desde o começo estava escrito." (DOURADO, 1999c, p. 183)

A figura de Xambá só se completava com a de seu cavalo, o Jaú: "Um cavalo branco, de crina flamejante, pingando estrelas, num revoar de relinchos e poeira luminosa". Assim como o Rocinante de Dom Quixote, ele transcendia a existência prosaica.

\begin{abstract}
Na memória de João o cavalo Jaú se casava e se fundia com dois outros cavalos: o cavalo santo de São Jorge guerreiro e lunar, e o cavalo branco de Buck Jones da fita em série. Ele não podia ver um sem se lembrar dos outros. No tropel de suas noites, nas suas noites de menino, os três se dissolviam numa só brancura nas campinas do céu. (DOURADO, 1999c, p. 184)
\end{abstract}

Segundo o narrador, a imaginação do menino transfigurava em bronze Xambá e o cavalo Jaú. Metaforicamente, os dois eram um só, formavam uma "estátua equestre". O peito largo do cavalo era como "a proa de um barco que varava as ondas."

Quando os meninos brincavam, jogavam malha e brigavam, logo imaginavam a chegada de Xambá e seu cavalo. Ele brincava com as crianças, divertia-se e logo partia a galope: "Xambá cavalgava sobre as águas, corria o horizonte, demandava o deserto."

As histórias sobre o heroi se multiplicavam. O narrador personativo se despersonaliza e personifica os refletores para encenar as suas impressões. Uma vez Xambá foi preso.

Uma vez (contavam) a polícia tinha conseguido deitar mão nele. Tomado o revólver. [...] A gente não acreditava, não podia acreditar. Ele de cabeça erguida, olhando para cima. De repente, sem que soubessem como, Xambá deu um pulo para trás, num átimo estava esganchado em cima do cavalo. Ouviu-se um tiro, outros. Xambá tinha sumido no fim da rua, envolto numa nuvem de poeira. Ainda não 
nascera o homem para sujigá-lo. Quem vê que levavam para a cadeia aquele cabra fulo! (DOURADO, 1999c, p. 186)

Certa vez, na farmácia de seu Gaetano, que ficou pasmo de vê-lo na sua frente, em carne e osso, assim como o capiau que aguardava na loja, ao comprar algumas coisas, Xambá descobriu e roubou o seu revólver. Diziam que foi assim que conseguiu outra arma para enfrentar os soldados no pasto de seu Luquinha: "Foi assim (contava-se) que Xambá arranjou o Colt de cavalinho, especial de bom, que iria cuspir fogo, muita morte, mandada ou por puro gosto." (DOURADO, 1999c, p. 187)

Mas segundo seu Gaetano, a história não foi bem assim. Dizia que tinha vendido o revólver pra ele por um preço bem superior, que tinha passado "uma boa manta em Xambá." E, segundo o refletor, outra era a verdade.

Mas quem é que ia acreditar na versão daquel italiano seu Gaetano? A cidade, a gente menino queria, na sua crônica, preferia a outra versão, o caso que o capiau primeiro contou. (DOURADO, 1999c, p. 187)

O narrador fala-nos da visita soberba de Xambá à Casa da Ponte e, em especial, do caso que o menino refletor João viu e ouviu.

\begin{abstract}
Uma vez João viu, ainda se lembrava, como esquecer aquela tarde de tiroteio? [...] Subiu na janela e ficou olhando o quintal da casa do coronel Tibúrcio, para ver se via alguma coisa, os tiros vinham de lá. Xambá (soube depois) veio saltando os muros dos quintais, os soldados atirando em cima dele [...]. O corpo fechado, nunca que eles iam acertar em Xambá. [...] Xambá deu um salto de cima da escada, correu para o muro mais perto, pulou para a rua. [...] Ninguém ouviu mais falar de Xambá naquele dia, ele ganhava os caminhos do mundo. (DOURADO, 1999c, p. 187-188)
\end{abstract}

Segundo o refletor, a visão mais sublime de Xambá quem contou foi Zito. Ele viu Xambá baleado procurando ajuda na casa do dr. Alcebíades.

Ao contrário do de-costume, ele vinha numa marcha vagarosa, o corpo meio bambo na sela, o cavalo é que guiava. Não saltou do cavalo, deixou o corpo ir se derramando de banda. Zito cuidou que Xambá estaba bêbado, vinha cambaleando em direção à porta do dr. Alcebíades, se escorava na parede, a mão segurando a barriga que nem fosse vomitar. Não estava bêbedo não, arrematava Zito. Tinha sido é baleado, vinha buscar socorro médico. (DOURADO, 1999c, p. 188-189) 
Importa ressaltar que, neste episódio, o narrador personativo se multiplica nos diversos pontos de vista coletivos (a gente) e individuais (João e Zito) acerca de Xambá, que se iniciam de modo sublime e culminam de modo grotesco. Assim, neste jogo narrativo, a imagem mais elevada e a mais baixa do heroi já estão aqui reunidas, assim como a do corpo fechado e a do corpo baleado.

Sob a Magia da Dor

Neste episódio, conta-nos inicialmente o narrador personativo em terceira pessoa, encontramos João de volta a Duas Pontes, muitos anos depois, já homem feito. Visitava o dr. Alcebíades, amigo de sua família, que o iniciou desde menino no mundo da literatura, emprestando-lhe alguns livros como os Sermões do Vieira. O narrador nos conta que ele perdera a fé e não ia mais à missa, coisa que entristecia a mãe. E, então, diante do portão do consultório do dr. Alcebíades, o homem João se lembra do menino João. $O$ narrador nos dá a impressão do refletor.

Agora João estava de novo diante da porta do consultório. Custou a bater, temendo interromper a conversa de um médico e um menino lá dentro faz muitos anos.

João sorriu diante da lembrança daquele menino. Era a mão do menino ou a mão do homem que ia bater agora naquela porta, ele se indagava. (DOURADO, 1999c, p. 190)

Os dois se encontraram, sorriram e conversaram muito durante a tarde inteira. Relembraram dos tempos antigos de Duas Pontes, das histórias alegres e tristes. Nas recordações, os brilhos das coisas se perdendo, devorados pelo tempo perdido.

E a tarde se encheu de sombras e de lembranças, de gotas de óleo pingando. E as histórias, boas e alegres e tristes, à luz da distância, na sombra da tarde, perdiam o brilho, ganhavam a lucidez dos fantasmas, o tom cinza esbranquiçado, tinham o mofo das coisas velhas. (DOURADO, 1999c, p. 191) 
O médico Ihe pergunta há quanto tempo João partiu de vez de Duas Pontes: "Vendo a velhice, a devastação, o trabalho do tempo no rosto enrugado, na cabeça branca, João disse mais de vinte anos" (DOURADO, 1999c, p. 192). Em seguida, João the indaga sobre o dia em que atendeu o jagunço Xambá baleado.

A narrativa, então, desloca-se do narrador personativo e passa a ser a perspectiva em primeira pessoa do dr. Alcebíades sobre o tempo e a experiência daquele acontecimento com Xambá.

Da pessoa de Xambá eu posso falar. Das suas proezas não, que
essas eu só sabia de ouvir dizer, como toda gente. Só que não eram
assim tão coloridas e farfalhantes, tão heroicas e tenebrosas feito
você pintou. Só posso dar o testemunho do caso que comigo se
passou. Você vai juntando essas histórias, depois tira a limpo. É
capaz de não valer a pena, o que resta é apenas fumaça, desilusão.
Mas de um homem sempre alguma coisa fica, quando nada nas
lembranças, esperando a ressurreição. Feito dizem: Deus é que sabe
por inteiro o risco do bordado. (DOURADO, 1999c, p. 193)

Nessas palavras do médico, há uma auto-referencialidade à estrutura de composição do próprio livro $O$ Risco do Bordado: a conexão entre o mito e a realidade, o palimpsesto e 0 texto, a imaginação e a materialidade, a lembrança e o esquecimento, o risco e o bordado, o não-ser e o ser, o nãosaber e o saber.

A visão narrativa em primeira pessoa desdobra-se, como sabemos, na interação do eu narrante (presente) e do eu narrado (passado), do espaço e do tempo. Há uma distância temporal e uma metamorfose existencial. Os efeitos do passado no presente dramatizam a recordação. O narrador fala do que viu, ouviu e viveu.

A primeira, a única, a última vez que eu vi Xambá de perto foi aquela vez. Eu estava aqui sozinho no meu consultório. [...] Numa dessas vezes eu vi uma sombra grandona detrás daquela porta de vidro. [...] Agora batia com força, em tempo de me quebrar o vidro. Não tive jeito senão me levantar e ir abrir a porta.

Vi então que era Xambá. [...] O rosto contraído, um olho fechado, ele estava sentindo muita dor. E esta agora, foi o que primeiro pensei, já via de longe as complicações. (DOURADO, 1999c, p. 193-194) 
Nas lembranças do médico, a presencialização das impressões do outrora no agora.

Eu ia atender Xambá, não tinha outro jeito, era a minha obrigação. [...] la desabotoando a camisa, a calça, ficou pelado na minha frente. Que tamanhão de homem! Piloso. Que musculatura! Só então reparei no sangue que escorria novo pela perna esquerda. Ele não tirava a mão do ferimento, devia estar sofrendo muito. Olhava para mim, perguntando com os olhos o que é que eu ia fazer. (DOURADO, 1999c, p. 194-195)

Ao verificar a gravidade do ferimento, e a falta de recursos para a cirurgia no consultório, o médico tenta convencê-lo a ir para a Santa Casa, em vão. Insiste mais uma vez dizendo que ele não suportaria a dor.

Ele ia chiar de dor, não aguentava. Eu aguento, doutor, foi o que ele falou, pode começar. Como eu me mostrasse incrédulo, ele disse já aguentei pior, a gente experimenta, não custa nada tentar. Ele ia chiar de dor, eu era capaz de apostar que aquele homem não aguentava nem a metade do que eu ia fazer. (DOURADO, 1999c, p. 196)

Na cena recordada e revivida, destaca-se a mútua interação entre os sentimentos de Xambá e os do médico. Os dois externa e internamente travam uma luta contra os nervos e contra a dor. $O$ médico experimenta epifanicamente a existência de um outro eu, um duplo dentro de si mesmo.

Foi então que alguma coisa estranha se passou comigo, não sei como explicar. Uma espécie de perversidade. [...] Eu queria ver até onde aquele homem tão macho como se dizia, tão forte e corajoso, aguentava dor. Ver até onde eu suportava o sofrimento alheio, eu que às vezes sou de natural delicado. [...] Pois é, eu queria era testar os meus nervos, ver como se comportavam as minhas mãos. Era como se eu tivesse um outro dentro de mim, falando por mim, agindo por mim. [...] Eu disse tem mais, não pode se mexer, tem de aguentar firme nos arreios, seu moço! Agora é que eu quero ver se macheza é coisa para toda hora ou se é roupa só de domingo. [...] Eu ia lutar com ele, eu ia lutar contra os meus nervos, ele contra a sua dor. la se ver quem era capaz de levar mais longe o desafio. Uma aposta terrível que a gente mudamente se fazia. (DOURADO, 1999c, p. 196197).

"E a coisa começou." Assim o narrador anuncia a João a experiência da verdade paradoxal que mobiliza a alma e o corpo, o pensar e o sentir, a palavra e o silêncio. A despersonalização e a duplicidade do ser que desvela o desconhecido e o inesperado. 
Eu agia que nem um autômato. Era como eu disse - feito tivesse algum outro dentro de mim, um duplo que até então eu não conhecia. [...] No que eu pensava mesmo afincado era numa coisa: na infecção, no peritônio. A palavra me zunia nos ouvidos, vibrava nos tímpanos, como as batidas de um ferreiro, uma araponga. Era de fora que a palavra vinha, não de dentro de mim. Feito alguém gritando peritônio, peritônio, peritônio. [...] No entanto eu não gritava, era mais silencioso e agudo do que nunca, tinha uma habilidade guardada no corpo que eu mesmo ignorava, uma força que me nascia naquele momento. (DOURADO, 1999c, p. 197-198)

O médico se espanta com sua própria força e a de Xambá. Os efeitos do passado ainda se presentificavam: "E eu não gritei, não gritava. Ele também não dava um grito. [...] Nunca na minha vida eu vi nem vou ver uma capacidade de sofrer calado, de aguentar a dor feito aquela." (DOURADO, 1999c, p. 198)

$\mathrm{Na}$ dramatização dos eventos, a integração do passado, do presente e do futuro. Ao movimento físico do ir e vir da cirurgia corresponde o ir e vir dos sentidos do médico e do paciente. E assim como João, o leitor também é audiência, sofre os impactos do narrar-reviver.

\footnotetext{
Aquele homem me vencia, aquele homem ia me vencer. Eu me vencia, trabalhava maquinalmente, as minhas mãos não me pertenciam. E por mais que eu me vencesse, aquele homem me venceria. Eu estava dividido, por mais vitorioso que eu ia me achando. E sentia em tudo aquilo uma estranha alegria, uma feroz alegria de cavalo selvagem solto no pasto. (DOURADO, 1999c, p. 198-199)
}

A narrativa dramática de Autran Dourado não privilegia os fatos acontecidos, mas os efeitos e as reflexões provocados na enunciação e no enunciado. O narrador dr. Alcebíades e o personagem-protagonista dr. Alcebíades não se apresentam como uma oposição de sujeito e objeto, mas como complementariedade dos opostos. $\mathrm{O}$ eu narrante revive no presente $\mathrm{O}$ drama do eu narrado. $O$ acontecido volta a acontecer impedindo que a razão e a paixão se diferenciem. As expressões anunciadas e sentidas "estranha alegria" e "feroz alegria de cavalo selvagem" remetem-nos à visão dionisíaca do mundo, à contradição do ser e do não-ser, à abissalidade da experiência do homem e do mundo, à tragicidade do ser da própria realidade. Como dissemos, 
a narrativa dramática de $O$ Risco do Bordado diversamente modula a verdade da arte como jogo de escrita da morte inerente à própria vida.

A experiência do narrador reafirma a verdade que antecede e excede a ciência do médico e do homem. O sentido profundo do passado ainda ressurge na superfície do presente. Na busca do tempo perdido, proustianamente se redescobre a abissalidade do ser humano e do mundo. Como dizia Nietzsche, “O próprio ver não é - ver abismos?" (NIETZSCHE, 2011b, p. 149).

\begin{abstract}
E quando tudo acabou, eu olhei para o homem. [...] Ele estava alagado de suor, um suor mal-cheiroso que até hoje de vez em quando agora eu sinto no nariz. Eu também estava molhado, nunca tinha visto aquilo, nunca tinha vivido sensações tão fortes, não sabia até que ponto um homem pode se superar sob a magia da dor. Até que ponto se pode aguentar uma dor, até onde chega a verruma da dor. (DOURADO, 1999c, p. 199)
\end{abstract}

Nas palavras do narrador, no logos poético que suplanta o logos científico, desvela-se a linguagem do próprio ser, e não simplesmente a do homem. Como vimos na primeira parte desta tese, a hermenêutica de Heidegger e Gadamer assinala a origem e o jogo da obra de arte como desvelamento da própria verdade do ser. Nessa perspectiva ontológica, portanto, reafirmamos que a narrativa dramática de Autran Dourado incessantemente encena, nos sete blocos narrativos, a verdade paradoxal do ser, e não a verdade lógica do homem demasiado humano. O homem não é, pode ser. Para além das roupas superficiais, do rosto externo, da figura heroica, imaginada ou física do homem, manifesta-se a verdade narrativa: o ser não é, devém. Simbolicamente, o narrador, neste ponto, não utiliza a palavra "Xambá", mas a palavra "homem". Ele viu o homem, não o heroi.

Aquele homem não era um homem, era um bicho. Não, não era um bicho, um bicho se encrespa, refuga. Aquele homem era um demônio? Um cavalo não é capaz de ser outra coisa além de um cavalo, não vai depois do seu corpo. Aquele homem era desumano, é só o que eu posso dizer. (DOURADO, 1999c, p. 199)

Ele viu, dionisiacamente, além das roupas do homem: "Aquele homem era desumano." O termo "desumano" refere-se à visão pré-helênica ou dionisíaca (poética, ontocêntrica) e não à visão helênica ou humanista (lógica, 
antropocêntrica) do homem e do mundo, conforme nos ensina Eudoro de Sousa, em seu livro Dioniso em Creta \& Outros Ensaios (1973, p. 146). Desumano é o ser trágico da própria realidade, a abissalidade que antecede e excede a definição racional do homem. O que o narrador "nunca tinha visto", "nunca tinha vivido" e "não sabia" epifanicamente aconteceu. O nada aconteceu. A narrativa autraniana desvela a nova visão, a nova vida e o novo saber do novo homem, ou seja, do homem que supera ou vence a si mesmo, que se transumaniza, desumaniza ou desconstroi a forma petrificada, lógica e abstrata do homem. A visão trágica do homem e do mundo implica o novo saber, "o saber pelo sofrer", o pathei mathos, na formulação do poeta trágico Ésquilo. "Um homem pode se superar sob a magia da dor", na formulação do narrador dramático dr. Alcebíades.

Em O Risco do Bordado, a maior prova de que o homem se desumaniza, supera a si mesmo, põe-se em travessia, experimenta a "verruma da dor", está na configuração do próprio personagem-metáfora João. Essa mesma expressão é recorrente no livro. Todos os personagens do livro vivem a "verruma da dor", nos sete blocos narrativos. Mas só João supera a si mesmo, e não sucumbe. Os outros se matam, se aprisionam ou se amortalham em vida. Todos experimentam o "oco do vazio", e fogem de alguma maneira. Todos morrem, mas só o artista João morre e devém. Elucidativos são os versos do poeta Goethe em "Nostalgia de Bem-Aventurança":

\footnotetext{
E enquanto não entenderes Isto: - Morre e devém! -, Serás só turvo conviva Nas trevas da terra-mãe.
}

(GOETHE, 1958, p. 169)

O episódio "Sob a magia da dor" destaca também as reflexões de João ao ouvir a narração do dr. Alcebíades. Como o próprio médico disse antes de iniciá-la:

Você vai juntando essas histórias, depois tira a limpo. É capaz de não valer a pena, o que resta é apenas fumaça, desilusão. Mas de um homem sempre alguma coisa fica, quando nada nas lembranças, 
esperando a ressurreição. Feito dizem: Deus é que sabe por inteiro 0 risco do bordado. (DOURADO, 1999c, p. 193)

Importa lembrar também que este episódio começa falando que João fez sua iniciação literária desde menino com o médico, que the emprestava os Sermões de Vieira. Como se sabe, Vieira é um escritor barroco que se utiliza do método dramático de composição e insere a própria figura do artista (autor, criador) dentro da obra em diálogo com o leitor, além de nos ensinar a "morrer em vida". E Machado de Assis é também citado no início da narrativa numa clara alusão ao mestre carapina das "memórias póstumas" e do "defunto autor".

A narrativa de repente volta-se novamente do dr. Alcebíades para o narrador personativo que registra as impressões do refletor João diante das reações do médico. $\mathrm{O}$ drama narrado se reflete na corporalidade dos dois. $\mathrm{O}$ efeito patético se destaca: "João olhou para o dr. Alcebídades e viu que as mãos tremiam, a testa porejava suor. Ele não sabia o que dizer, esperava que o dr. Alcebíades acabasse a sua história." (DOURADO, 1999c, p. 199)

O narrador personativo vai assinalando para o leitor as conexões entre a narrativa do dr. Alcebíades e as experiências de vida de João. Como quem também nos sugere o caminho para interpretarmos a história subliminar, o palimpsesto de O Risco do Bordado.

\footnotetext{
De novo o silêncio caiu entre João e o médico. E, sem saber por quê, o menino dentro de João ia juntando numa só imagem as figuras nevoentas de tia Margarida, de tio Zózimo, de vovô Tomé, de tio Maximino... - estrelas formando a Constelação da Dor.

É estranho o homem, não é? Era só o que agora sabia dizer o dr. Alcebíades.

E os dois ficaram muito tempo calados, os olhos no chão, na boca o gosto da dor. (DOURADO, 1999c, p. 200)
}

$\mathrm{Na}$ unidade e diversidade dos blocos narrativos e dos personagens (familiares), nas estrelas e na Constelação da Dor, na parte e no todo da narrativa dramática de $O$ Risco do Bordado, encontramos sempre a verdade originária, poética e dionisíaca de que o homem é o ser mais estranho, pois se afasta dos limites do familiar e conhecido e experimenta a abissalidade do 
próprio ser. Não se trata aqui de uma visão objetiva, mas poética da essência do homem.

Nas palavras do dr. Alcebíades de que "é estranho o homem", ressoa a referência ao poetar pensante da tragédia grega Antígona, de Sófocles, presente nas palavras do Coro:

\author{
Muitas são as coisas estranhas, nada porém, \\ há de mais estranho do que o homem. \\ [...] \\ Pondo-se a caminho em toda parte, desprovido de experiência \\ e em aporia, chega ele ao Nada. \\ A morte é a única agressão, de que não se pode defender \\ por nenhuma fuga, embora consiga esquivar-se habilmente \\ às penas da enfermidade.
}

(SÓFOCLES, apud HEIDEGGER, 1987, p. 170)

E, nas palavras do eminente pensador Martin Heidegger, encontramos a elucidação hermenêutica da visão poética e trágica de Sófocles:

\begin{abstract}
O homem é to deinotaton o que há de mais estranho. Esse dizer concebe o homem pelos limites supremos e pelos abismos mais surpreendentes de seu ser. [...]

"Estranho" entendemos como o que sai e se retira do "familiar" (das Heimliche) i. é daquilo que nos é caseiro, íntimo, habitual, não ameaçado. $\mathrm{O}$ estranho não nos deixa estar em casa. Nisso reside o vigor que se impõe e subjuga (das überwaeltigende). O homem é o que há de mais estranho, não só porque conduz o seu ser no meio do estranho, assim entendido, mas por afastar-se e sair dos limites, que constituem, em primeiro lugar e às mais das vezes, a sua paisagem caseira e habitual, por transpor, como o que instaura vigor, as raias do familiar e se aventurar justamente na direção do estranho no sentido do vigor que se impõe. (HEIDEGGER, 1987, p. 172 e 174)
\end{abstract}

Assim, o homem é estranho (to deinotaton), porque não é senão a possibilidade de ser. A Constelação da Dor é o saber pelo sofrer o risco, a abissalidade ou finitude do bordado do próprio ser.

O Chicote de Prata

Neste episódio, temos a narrativa em primeira pessoa de tio Alfredo acerca de sua experiência com Xambá e sua amante Felícia na Casa da Ponte. 
Inicialmente, tio Alfredo comenta a visão que o menino João tinha de Xambá. Mais uma vez a narrativa discute a questão da interação entre a imaginação e a realidade.

\begin{abstract}
Visão de menino é assim mesmo, disse tio Alfredo quando João Ihe contou como ele menino via Xambá. Não digo que menino não veja as coisas direito. São as névoas nos olhos, feito você diz. É que menino vê muito, vê até demais da conta. Só que vê de través, junta o que sentiu e as coisas que aconteceram mesmo. Visão de menino é que nem visão de santo, tem lume nas bordas, pinga estrelas. Olho de menino vive cheio de neblina, depois com o tempo clareia, ou se apaga, não sei. Depois a gente vê melhor, melhor não digo, vê diferente, a força de antes vai minguando no escorrer do tempo. Tudo em menino é girândola, grito, susto, foguetório, brumado de sonho. (DOURADO, 1999c, p. 200)
\end{abstract}

O eu narrante tio Alfredo (presente) relembra a João a vida desregrada do eu narrado (passado). Os sofrimentos que causava ao pai (vovô Tomé) e à mãe (vovó Naninha), as suas doideiras, as suas valentias, as suas vadiagens de rua.

\begin{abstract}
Eu era um vagabundo, filho de pai fazendeiro, qualquer dia-feira pra mim era dia santo, domingo todo dia. Vivia nas estrepolias, nos desmandos, no sem-o-que-fazer. Minha vida era jogar bilhar e carteado no clube, beber cachaça, limpar a goelha com cerveja nas cantorias de viola, nos bailes do pessoal miúdo, da negralhada, da mocorongada. Aonde tinha função eu levava a minha pessoa folgazona. E eu falava e vivia era safadeza só, peruando mulher dos outros, em tempo de levar chumbo. O volume do revólver à mostra, eu desacatava, no desfastio eu afrontava. Vivia jogando a minha vida por nada, não dava valor nenhum ao sopro de alma que Deus me deu. (DOURADO, 1999c, p. 201)
\end{abstract}

Revela, então, como vivia também na Casa da Ponte, "metido com rapariga, no gozo bom da sem-vergonheira", e acabou se apaixonando pela prostituta Felícia. Por ela estava disposto a tudo, até a casar. Naquela época Xambá aparecia muito por lá, metendo medo em todos, menos nele.

Não queria apresentar medo, eu tinha uma fama, um nome a zelar. Eu me fingia à vontade, esticava as pernas, fazia um cigarrinho, pitava em compridas baforadas, ficava olhando para ele detrás da fumaça. (DOURADO, 1999c, p. 202) 
Mas, quando Xambá se engraçou por Felícia, o ciúme tomou conta de tio Alfredo e a vontade de matar passou a persegui-lo. O narrador destaca, então, a experiência emocional do personagem.

\begin{abstract}
Até que um dia ele foi se engraçar logo com a Felícia! Eu devia resolver, toda hora eu vivia só com aquele pensamento dizendo que eu tinha de resolver se era homem, já e agora. [...] É hoje, eu dizia a mim mesmo calado, a mão conferindo o formato do revólver na cintura. (DOURADO, 1999c, p. 203)
\end{abstract}

Por outro lado, a narrativa destaca a distância temporal e a metamorfose existencial do eu narrante (presente).

\begin{abstract}
Hoje eu não tenho mais dessas bobagens de macheza, sou um homem no meu natural, posso dizer - eu tinha era medo, medo escondido mas medo, apesar da ventania toda que eu soprava. Um medo enterrado dentro do porão do peito, debaixo da penúltima escama da alma. (DOURADO, 1999c, p. 204)
\end{abstract}

Nesse vai e vem da narrativa do passado ao presente e vice-versa, João assim como o leitor vão percebendo as máscaras ou roupas do homem tio Alfredo. Mas também experimentam com ele (eu narrado) os efeitos da morte, do ciúme e do ódio no abismo da alma humana, bem como a razão a impedir o deslimite.

\begin{abstract}
Eu vivia no fio da faca, brincava com fogo. Bem que dizem o capeta tenta e a faca entra. Muitas vezes era tão forte a chamada do abismo que eu tinha uma gana meio suicida de acabar com aquilo de vez, de olhar para ele com os olhos da afronta. Não cheguei até esse ponto, fui até na beiradinha, quase ali no grito. Foi Deus que não quis, meu anjo da guarda trabalhava por mim na moita. (DOURADO, 1999c, p. 204)
\end{abstract}

Nos silêncios de tio Alfredo e Xambá, que dividiam a mesma mulher, cada um aparecendo em horários diferentes, para não se encontrarem fatalmente, parecia que um "trato escondido" era feito: "A gente jogava um jogo muito perigoso." (DOURADO, 1999c, p. 204)

Até que um dia tio Alfredo aceita uma proposta indecente de Felícia para ver como Xambá se comportava com ela durante o ato: "Encurtando, o que ela queria: eu ficava escondido no quarto, ia ver uma coisa de cair pra trás." 
(DOURADO, 1999, p. 204). O eu narrante manifesta a sua visão crítica do eu narrado, mas também ainda os efeitos (ciúme, raiva) do acontecimento no presente.

No outro dia, até me envergonho de contar, tanta baixeza a gente faz, no quarto de Felícia, me escondi detrás de um armário, fiquei vendo. [...] Ainda hoje vejo ela ronronando no cangote dele, gata sacana! [...] Eu espumava de ciúme, nunca fui de aguentar muito. Foi pra fazer fosquinha em mim que ela me chamou, eu quase berrei.

Ele dava quase dois dela. Assim pelados, ele mulato - ela branquinha, os dois, um era o contrário do outro, mas como se acasalavam! Minha raiva era surda, um deslocamento de terra debaixo, cuidava que meu peito ia estourar. (DOURADO, 1999c, p. 205)

Dá-se, então, o inesperado. Epifanicamente, tio Alfredo presencia a cena grotesca que revela o desmoronamento ou rebaixamento da imagem do valentão e destemido heroi de Duas Pontes.

De repente eu vi, vi o que nunca pensei ver num homem daqueles, da sua fama, da sua iguala. Xambá caiu de quatro, que nem fosse montaria. Felícia pulou pra cima dele, esganchada no lombo de Xambá. O chicotinho de prata na mão, ela chegava nas ancas dele umas lambadas, que nem um cavalo. Ele apertava a musculatura, aguentava firme, suava. E eu vi na cara daquele homão macho, daquele cabra de contada memória, um principinho de riso de gozo por debaixo das rugas da dor. (DOURADO, 1999c, p. 205)

Interessante assinalar como a narrativa autraniana repete estruturas e palavras ("vio o que nunca pensei ver", "suava", "dor") produzindo efeitos e sentidos diferentes no narrador e na audiência (João, o leitor). Mas, em toda repetição, o mesmo movimento lúdico de elevação e queda. Ao contrário do efeito épico contado em "Estátua Eqüestre", do efeito trágico contado em "Sob a magia da dor", agora o efeito contado por tio Alfredo em relação à estranheza do homem Xambá é cômico e grotesco. Assim, vamos recebendo as diversas facetas ou roupas do homem: a épica, a lírica, a trágica e a cômica. E na macroestrutura da obra percebe-se também a mistura dos diferentes gêneros narrativos.

O eu narrante diante do espetáculo grotesco sente o desmoronamento de si mesmo, e a raiva de Xambá por ciúme se transforma em nojo de si mesmo e desilusão dupla com respeito ao heroi e à amada Felícia. 


\begin{abstract}
A raiva que eu tinha virou nojo. Nojo de mim, dele não. Por estar ali vendo aquilo tudo, aquela humilhação, aquele vício. Eu que sempre achei que negócio macho-fêmea é coisa à parte, longe das vistas dos outros, coisa de quatro paredes. Eu me botava na pele dele, eu que no fundo tinha até uma certa vergonha de fazer as minhas coisas de dia, chegava a sentir as lambadas no lombo. Eu tinha nojo era de mim mas fingia que era dele que eu tinha nojo. Quis acabar com a pantomima, quis botar um ponto final naqueles dois. Dentro de mim eu queria acabar de vez com aquele circo de cavalinho. (DOURADO, 1999, p. 205-206)
\end{abstract}

Tio Alfredo, que era um homem desregrado em seus vícios, agora se pautava pela ordem e pela decência, numa clara contradição de seus princípios. Verifica-se aqui que as roupas ou máscaras do homem muitas vezes são apenas disfarces para se reafirmar a ordem estabelecida.

Quando o desenlace fatal parecia estar por um triz, o inesperado de novo acontecia. De repente Xambá se levantou abruptamente derrubando Felícia, vestiu-se às pressas e foi embora. E a narrativa, comicamente, como por milagre, anuncia que tio Alfredo sofria a sua conversão, se libertava e se salvava do mundo de pecados. Ele apenas atravessava da margem do descomedimento para a margem do comedimento.

Pronto, ele foi se embora. Dentro de mim um mundo inteiro desabou. Saí correndo, nem mesmo olhei para Felícia.

Desse dia em diante eu não passei mais pela Casa da Ponte, nem nunca mais botei os olhos em cima de Xambá. Aquilo me fez mudar de vida, foi a minha salvação. Acho que era o sinal que a minha alma andava esperando, os guizos das bandas de Deus. Ele também não voltou mais lá, mudou de pouso. (DOURADO, 1999c, p. 206)

\title{
Espessa Cortina da Morte
}

Neste episódio, reencontramos o dr. Alcebíades que, em primeira pessoa, narra ou reconta a João o caso de paixão e morte de Felícia por Xambá. Mostra a passagem dos tempos heroicos aos tempos modernos, do mundo das ninfas encantadas da Casa da Ponte ao mundo das pobrescoitadas e doentes da Santa Casa. Do tempo mítico ao tempo da razão. Não só a história dos homens, mas a história do mundo também tem diversas faces. 
Felícia, aquelas mulheres da Casa da Ponte. A Casa da Ponte não existe mais, derrubaram tudo quanto era casarão antigo, a igreja velha também se foi, o Largo do Carmo, tudo no chão, é o progresso. Aquelas mulheres da Casa da Ponte e dos outros bordeis. As ninfas malditas e encantadas da sua meninice... (DOURADO, 1999c, p. 207)

O narrador vai desconstruindo o mundo luminoso do menino João, jogando por terra as deusas imortais que não passavam de mulheres mortais, perdidas e miseráveis. Mas também assinala a importância que o homem João dá ao mundo das "coisas míudas". Sugere-se aqui a própria poética do romance autraniano a trabalhar com a "beleza do sentido comum das palavras", a "visão terrena das coisas", o "lugar-comum" e o "patético", conforme se verifica em Uma Poética de Romance: Matéria de Carpintaria (2000a, p. 47 e 91 )

Não eram ninfas coisa nenhuma, umas pobre-coitadas o que elas eram. Levadas para a vida por pobreza, imbecilidade, meio social cheio de besteiras. Gonorréias, sífilis, esse mundéu de flores pobres. [...]

Eu acho engraçado é você guardar esses nomes todos, compor uma ciranda com eles. Você vive pra isso, dá importância às coisas miúdas. (DOURADO, 1999c, p. 207-208)

Em seguida passa a falar de como Felícia chegou à Santa Casa já beirando a morte, dos seus cuidados e do que Ihe segredou um dia: "O fim de Felícia foi se acabar na Santa Casa, numa miséria de dar pena, um fiapo de gente." (DOURADO, 1999c, p. 208). Felícia queria compartilhar a sua verruma de dor: "Eu só queria era passar pra alguém, pra um homem assim feito o senhor, passar pra frente um peso que vive me puxando, me afogando a alma." (DOURADO, 1999c, p. 209)

Entre choros e lamentos, agonia e morte, Felícia the contou o seu caso de paixão violenta por Xambá e também o seu amor por tio Alfredo. Encontramos aqui uma narrativa de primeira pessoa (Felícia) dentro de outra narrativa de primeira pessoa (dr. Alcebíades) e seus efeitos e reflexões produzidos no médico (em João e no leitor). O dr. Alcebíades é narrador e audiência simultaneamente. 
Ela andava era de coração dividido, não sabia o que fazer. Não desgostava de Alfredo, mas gostar mesmo, gostar de verdade, era de Xambá que ela gostava. Maluca por ele, pensava nele o dia inteirinho, de noite rolando na cama pensava em como tinha sido com Xambá de dia. [...] Às vezes queria se matar, tentava a formicida, o bilhete em cima do criado-mudo, o escarcéu. Elas às vezes são românticas, você sabe, é preciso não esquecer. Mas cadê coragem? (DOURADO, 1999c, p. 211)

A narrativa de dr. Alcebíades vai se embaralhando com a de Felícia. Ambos compartilham as dores do amor, da agonia e da morte.

\begin{abstract}
Mas maquinou um plano terrível, diabólico mesmo, o capeta é que ia resolver, foi o que ela falou. Ela apenas ajudaria com o corpo, era um brinquedo na mão de Deus... ou do diabo, eu mentalmente corrigia. Tentação, doutor, coisa-ruim, era só isso que ela sabia dizer. Aquela ideia nasceu uma sementinha dentro dela, foi crescendo, crescendo, virou jequitibá velho. E ela não sabia o que fazer com aquele tamanhão de árvore, aquela galheira toda embaralhando, ensombrando dentro dela. (DOURADO, 1999c, p. 212)
\end{abstract}

Indecisa entre Xambá e tio Alfredo, entre paixão e razão, amor e morte,

Felícia maquina um jeito de sair dessa encruzilhada do sentir e do pensar.

\begin{abstract}
Ela falava em suicídio, morta por um dos dois, mas no fundo o que queria era que um matasse o outro, que decidissem por ela. Já que o coração não se resolvia, era o caso de uma disputa. Alfredo era a vida segura, regalada. Xambá a vida aventurosa, o amor mais fundo. Sonhava em sair com ele pelo mundo, começaria vida nova debaixo do mando de um homem macho e corajoso feito ele, de fama tão decantada. Vendo as coisas dos dois lados, com Xambá seria melhor, ele falava até em assentar juízo, se casava com ela, ia ser vaqueiro, trabalharia de peão numa fazenda qualquer longe daqui. Mas alguma coisa prendia Felícia a Duas Pontes, àquela vida. (DOURADO, 1999c, p. 212-213)
\end{abstract}

Ao mesmo tempo que sonhava com a liberdade prometida por Xambá, considerava-se indigna de ter uma vida ordenada, familiar, carinhosa, amorosa: "A sua vida era suja demais, ela dizia." (DOURADO, 1999c, p. 213). Foi então que maquinou a ideia para que Alfredo se encondesse no quarto enquanto estivesse com Xambá: "la ver uma coisa que ele nunca tinha visto, foi o que disse." (DOURADO, 1999c, p. 214).

Na narrativa recontada por dr. Alcebíades, percebe-se uma certa adesão aos sentimentos e artimanhas de Felícia durante o ato com Xambá. Nas descrições, adjetivações e diminutivos, um certo prazer no ato de contar. 
Ela começou acarinhando muito Xambá, fazia as delicadezas, as coisas melhores e mais mansas que ela sabia fazer. Entre um carinho e outro, uma palavrinha aqui outra ali, semeava. Então, foi, pediu. Ele ficava de quatro no chão, só isso. Ele nunca tinha feito aquilo, a posição era meio vexante, ele não se rebaixava. Ela pensou que ia levar um tapa na cara, contava com tudo no que rascunhara. Tanto ela fez, tanto pediu e implorou entre beijos e palavrinhas que só mulher sabe dizer, que ele não se fez mais de rogado, cedia. (DOURADO, 1999c, p. 214)

Nesse jogo de razão e coração, inteligência e sedução, que envolvia os três, Felícia pensava inicialmente em criar a situação propícia de desproteção do heroi e o efeito do ciúme em Alfredo para que ele, inconsciente da maquinação, matasse Xambá. Mas, em seguida, resolve montar no lombo de Xambá e, com o seu chicotinho de prata, que fustigava o cavalo Jaú nas correrias, começa a the aplicar fortes e sucessivas lambadas. O narrador destaca as reflexões de Felícia.

\begin{abstract}
Alfredo com certeza espiando tudo. Ela esperava, ele devia de acabar logo com Xambá. Não tinha pedido nada a Alfredo, nem trabalhado nada, só esperava. Por que ele não se mexia, não fazia alguma coisa? O que ela estava fazendo era danado de perigoso. Mesmo na desvantagem, Xambá podia matá-la. Diziam que ele tinha o fôlego e o pulo do gato, repentino. De um salto se armar, aí acabava com ela, ela mais Alfredo.

Ele aguentou firme mais algumas lambadas, ela não entendia aquela mansidão de bicho de sela. Não entendia por que Alfredo custava tanto a atirar. (DOURADO, 1999c, p. 215)
\end{abstract}

Nessa espera de agonia e morte, Felícia de repente vê Xambá se levantar bruscamente, atirá-la longe e vestir-se ligeiro. Ainda esperou o pior imaginando-se descoberta por eles em suas artimanhas. Como em outros episódios do livro, repete-se a estrutura e a experiência de abissalidade do ser. O Nada acontecia. Na narrativa dramática de O Risco do Bordado, importam os efeitos, não os fatos. $O$ drama é estático, não é cinético. $O$ drama é de paixão, não é de ação.

Ela esperava que alguma coisa acontecesse, não acontecia. Ele apanhou a arma, o chicote no chão, olhou bem para ela. Nos olhos arregalados, o espanto, o medo. Não de Alfredo, ela agora tinha certeza - de jeito nenhum ele viu nem sentiu que Alfredo estava no quarto. $O$ medo que ele tinha era dela: olhava-a como se ela fosse pactária, o próprio coisa-ruim em pessoa. Apertou os olhos feito agora ele estivesse sentido muita dor, feito querendo apagar uma 
visão dolorosa. Sem dizer palavra, partiu de vez. (DOURADO, 1999c, p. 215)

O mesmo drama é encenado diversamente. No episódio anterior "O Chicote de Prata", a perspectiva é de tio Alfredo. Neste episódio "Espessa Cortina da Morte, a perspectiva é de Felícia. Em qualquer perspectiva, desvelase sempre a finitude ou a insubstancialidade do ser humano e do mundo. A identidade é a própria alteridade. O nada é o véu do ser.

As Malhas da Lei

Neste episódio, o narrador personativo em terceira pessoa despersonaliza-se e personifica o personagem refletor seu Dionísio, delegado naquela época em Duas Pontes, que passa a mostrar a João as suas lembranças de Xambá.

\footnotetext{
Seu Dionísio ia falando. Se lembrava de Xambá? Lembrava muito, lembrava demais até. [...] Por que João queria tanto saber? Lembrava-se. Só que fazia um despropósito de tempo.

[...] Agora que João tinha falado, se lembrava bem, clarinho agora, água de mina. (DOURADO, 1999c, p. 216)
}

Segundo seu Dionísio, Xambá só reinou enquanto recebeu proteção do coronel Tibúrcio, quem mandava em Duas Pontes e devia alguns favores ao jagunço. Logo que se tornou delegado quis acabar com aquelas mortes e estragos, mas precisava conversar primeiro com o coronel. Ficou acertado que o coronel falaria com Xambá que não poderia pernoitar na cidade, só poderia ficar de passagem, não poderia passar diante da cadeia, para não afrontar os soldados, e que não poderia mais roubar cavalo nenhum dos fazendeiros, caso contrário perderia a proteçaõ do coronel.

Mas Xambá acabou roubando uns cavalos do lldefonso Guedes, casado com a filha do coronel. Seu Dionísio recebeu então as ordens de que deveria prender Xambá. 
Seu Dionísio agora vivia na espera. Um dia, foi, teve notícia de Xambá. Ele tinha atravessado a divisa, vindo pro lado de Minas. Dormia numa tapera perto da Fazenda da Cachoeira. Seu Dionísio, perdigueiro, foi atrás, queria o homem vivo, deu ordens para a gente embalada. Cercou Xambá ali mesmo, pertinho. Ele e mais um outro seu companheiro conhecido por alcunha de João Cagadinho. O nome não era muito cheiroso mas o cabra tinha um fumação de valentia. $O$ encontro finalmente se deu. O primeiro tiroteio foi pro ar, conforme as ordens. Os dois não tinham como aguentar, só deram uns tirinhos de nada, estavam bem cercados. De repente, sem que ninguém esperasse, Xambá gritou que ia sair, se entregava. (DOURADO, 1999c, p. 219)

Na cadeia, seu Dionísio tentou, no início, verbalmente, retirar a verdade de João Cagadinho acerca de onde tinham escondido os cavalos. Mas, foi em vão. Ordenou ao cabo Militão, então, que arrancasse a verdade dele à força a golpes de tala no lombo. Mas, de novo, foi em vão. O refletor seu Dionísio assim registra o momento.

Mas não é que aquele porqueirinha, aquele fiapo de gente, aquele merda seca, até meio cacudinha ele era, cuja coragem não condizia com o nome nem com a pessoa, não é que ele nem piou?

João Cagadinho caiu meio morto num canto, esmolambado. (DOURADO, 1999c, p. 219-220)

Na vez de Xambá, seu Dionísio, muito respeitoso, também tentou obter a resposta, mas o jagunço ficou calado. Ordenou ao cabo Militão que também castigasse Xambá com as talas no lombo. Foi aí que, epifanicamente, seu Dionísio experimentou algo inesperado.

Aí então seu Dionísio viu o que nunca imaginou. Na primeira lambada de cabo Militão, Xambá caiu de joelhos, as mãos pro ar, rogando. Tivessem pena dele, pelo Santo Amor Divino, não carecia bater, ele falava tudo. Eles não eram dois mas três, conforme falou. $O$ terceiro, um certo Domingão, tinha ficado escondido com os cavalos num capão junto da divisa, no Tanquinho. Era eles irem lá e pegavam o homem. (DOURADO, 1999c, p. 220)

O delegado seu Dionísio registra sua experiência diante dos efeitos dramáticos da cena, os impactos do sofrimento e da fraqueza humanos que the marcaram os sentidos e a memória.

E Xambá, a gente não podia acreditar, aquele homão temido, chorava diante da soldadada, uma vergonheira. Chorava pelos olhos, pelo nariz, pela boca. A cara lustrosa de lágrima, um meninão se borrando. 
O que eu senti foi mais nojo daquele homão chorando, disse seu Dionísio. Além do mais o homem era traidor, não carecia de ter dito o nome do Domingão, a gente nem sabia que ele andava por aqui. (DOURADO, 1999c, p. 220)

O narrador personativo assinala, posteriormente, a conversa privada entre seu Dionísio e Xambá. Mostrava-se agradecido com a ajuda, com a delação do comparsa Domingão, que tanto queria capturar: "Seu Dionísio não era mal agradecido, foi o que disse a modo de engambelar Xambá." (DOURADO, 1999c, p. 220-221). E discretamente anuncia que deixaria a porta da cela encostada para que, mais tarde, quando o cabo Militão estivesse a roncar no seu sono pesado, pudesse fugir. Mas, por outro lado, ardilosamente, antes de ir pra casa descansar, disse ao cabo que reforçasse a guarda daquela noite, de fuzil embalado e tudo mais, temendo a fuga de Xambá. E ainda o alertou de que, se houvesse alguma novidade, não precisava mandá-lo chamar, pois confiava na melhor decisão que poderia tomar.

Assim, nas artimanhas de seu Dionísio, pode-se prever o destino de Xambá. Ao iludir a todos, a visão dionisíaca reúne, mais uma vez, a imaginação e a realidade, a ficção e a verdade, a vida e a morte, a desordem e a ordem, o trágico e o cômico. No eterno retorno do ser, a realidade da ficção é a ficção da realidade. Afinal, o mito é o nada que é tudo.

Seu Dionísio soube depois: Xambá - cabo Militão não sabia por que artes mágicas ( $\mathrm{O}$ senhor deixou a porta da cela aberta, perguntou o cabo. Não, disse ele, tranquei bem trancado, me lembro), Xambá conseguiu abrir a cela, saltou o muro da cadeia que nem um gato. Quando na rua, começou a fuzilaria.

O homem tentou fugir, foi o que contou seu Dionísio depois ao juiz. O juiz franziu a testa, pensou bem, decidia. Tentativa de fuga, concluiu dando o caso por encerrado. (DOURADO, 1999c, p. 221) 


\section{CONCLUSÃO}

Este trabalho teve como objetivo fundamental realizar um estudo hermenêutico acerca da arte como jogo e escrita da morte no romance $O$ Risco do Bordado, de Autran Dourado, que se estrutura como a interação mútua da ficção narrativa e do drama trágico.

A primeira parte, intitulada Hermenêutica, arte e jogo como escrita da morte, mostrou, no capítulo 1, como Martin Heidegger, na esteira da desconstrução nietzschiana da metafísica, relacionou a questão hermenêutica da verdade à representação da morte como experiência trágica do conhecimento. No capítulo 2, com base nos estudos de Hans-Georg Gadamer, elucidou-se o conceito de jogo como instância privilegiada de compreensão da obra de arte. Já no capítulo 3 , verificou-se a importância do drama trágico grego e sua relação com o mito e o culto de Dioniso para que se compreendesse a sua incorporação pela ficção narrativa moderna e contemporânea. Nessa perspectiva, preparou-se o caminho para revelar o diálogo da narrativa de Autran Dourado com o drama trágico, a sua visão mitopoética ou dionisíaca do mundo, bem como a sua correspondente poética não-aristotélica.

A segunda parte, intitulada A narrativa dramática de Autran Dourado, demonstrou, no capítulo 4, a importância do ponto de vista narrativo para a compreensão da técnica dramática de composição do romance moderno e contemporâneo ao qual se filia a obra de Autran Dourado, mostrando,

principalmente, a modulação do discurso bivocal de Gustave Flaubert, a contribuição de Henry James ao meditar sobre a arte do romance e ao criar a técnica do refletor narrativo ou a situação narrativa predominantemente personativa; bem como a revolução ou radicalização desta por James Joyce com sua teoria da prosa epifânica e do efeito trágico. Por fim, no capítulo 5 , caracterizou-se o drama de paixão em O Risco do Bordado, apresentando-se, primeiramente, a sua estrutura lúdica de composição ou planta baixa e, realizando-se, em seguida, um estudo hermenêutico dos seus sete blocos narrativos regidos singularmente pela escrita da morte. Nas narrativas de 
Autran Dourado, portanto, a morte se apresenta, primordialmente, como a personagem central que interrelaciona os planos da enunciação e do enunciado de seus textos regidos pela visão lúdica, dionisíaca ou mitopoética do mundo. A questão da finitude e da temporalidade é o problema hermenêutico fundamental que envolve o drama do narrador e dos personagens do universo autraniano. A narrativa de Autran Dourado vem se estruturando e modulando a partir da correspondência das artes barroca, romântica, simbolista e modernista, do hibridismo da lírica, da narrativa e do drama modernos, contribuindo, assim, para a renovação técnica e estilística da literatura brasileira contemporânea.

Nesta perspectiva, confirma-se que a arte como jogo e escrita da morte, na narrativa dramática de Autran Dourado, se representa como o símbolo do mundo, ou seja, o jogo dramático da ficção e da realidade, da literatura e da existência, da vida e da morte. Não é a subjetividade ou objetividade do narrador ou do personagem que se revela simplesmente, mas o sentido trágico da existência. Para além do sujeito, da subjetividade e da substância, a existência (o mundo concreto da vida) tem movimento próprio e lúdico. Nas palavras de Eugen Fink (1966), o jogo é o símbolo do mundo, não é simplesmente o jogo de pessoas.

O jogo do mundo não é o jogo de pessoa, porque é somente nele que há pessoas, homens e deuses; e o mundo lúdico do jogo do mundo não é uma "aparência", mas aparição. [...] A aparição é a máscara atrás da qual nao há "pessoa", atrás da qual não há nada mais do que justamente o nada. (FINK, 1966, p. 238 e 239, tradução nossa)

Enfim, na narrativa dramática de Autran Dourado, a configuração da existência, o retrato do artista ou o risco do bordado é a própria escrita da morte interior à vida, ou seja, da insubstancialidade do homem e do mundo no horizonte móvel do tempo. 


\section{BIBLIOGRAFIA}

\section{Obras de Autran Dourado}

DOURADO, Autran. Novelas de Aprendizado (Teia, 1947 / Sombra e Exílio, 1950) [1980]. Rio de Janeiro: Rocco, 2005a.

. Tempo de Amar [1952]. Rio de Janeiro: Rocco, 2004a.

. Solidão Solitude (Três Histórias na Praia, 1955 / Nove Histórias em Grupos de Três, 1957) [1972]. Rio de Janeiro: Rocco, 2004b.

. A Barca dos Homens [1961]. 6.ed. Rio de Janeiro: Rocco, 1999a.

. Uma Vida em Segredo [1964]. 9.ed. Rio de Janeiro: Rocco, 2001.

. Ópera dos Mortos [1967]. Rio de Janeiro: Rocco, $1999 \mathrm{~b}$.

. O Risco do Bordado [1970]. 9.ed. Rio de Janeiro: Rocco, 1999c.

. Os Sinos da Agonia [1974]. 4.ed. Rio de Janeiro: Rocco, 1999d.

. Uma Poética de Romance: Matéria de Carpintaria [1976]. Edição revista e ampliada pelo autor. Rio de Janeiro: Rocco, 2000a.

. O Meu Mestre Imaginário [1982]. Rio de Janeiro: Rocco, 2005b.

. Violetas e Caracóis [1987]. Rio de Janeiro: Rocco, 2005c.

. Um Artista Aprendiz [1989]. Rio de Janeiro: Rocco, 2000b.

. Vida, Paixão e Morte do Heroi [1994]. 3.ed. São Paulo: Global, 1997.

. Breve Manual de Estilo e Romance [2003]. Belo Horizonte: Editora UFMG, 2003.

. O Senhor das Horas [2006]. Rio de Janeiro: Rocco, 2006.

\section{Entrevistas, depoimentos e artigos de Autran Dourado}

DOURADO, Autran. Duas faces. Minas Gerais, Belo Horizonte, v. 1, n. 10, 5 nov. 1966, p. 6 . Suplemento Literário. 
. Personagem como metáfora. Minas Gerais, Belo Horizonte, v. 8, n. 380, 8 dez. 1973, p. 2-3. Suplemento Literário.

. Proposições sobre labirinto. Minas Gerais, Belo Horizonte, v. 9, n. 424, 12 out. 1974, p. 2. Suplemento Literário.

- Símbolo literário e símbolo psicológico: O mito ordenador. Revista do Brasil, n. 4, 1985, p. 126-129.

- Ofício (e glória) do escritor. Diálogo de Autran Dourado com Eneida Maria de Souza. Minas Gerais, Belo Horizonte, v. 20, n. 955, 19 jan. 1985, p. 2. Suplemento Literário.

Armas e riscos da escrita. Fragmentos de Autran Dourado. Seleção de Eneida Maria de Souza. Minas Gerais, Belo Horizonte, v. 20, n. 955, 19 jan. 1985, p. 3. Suplemento Literário.

. Remembranças de Hollywood. Minas Gerais, Belo Horizonte, 5 dez. 1987, p. 7. Suplemento Literário.

. Proposições sobre narrativa. Minas Gerais, Belo Horizonte, v. 22, n. 1082 , 15 ago. 1987, p. 7. Suplemento Literário.

. Proposições sobre Mito. Minas Gerais, Belo Horizonte, v. 22, n. 1094, 20 fev. 1988, p. 5. Suplemento Literário.

. Proposições sobre o símbolo literário. Minas Gerais, Belo Horizonte, v. 22, n. 1114, 21 jan. 1989, p. 6. Suplemento Literário.

A (in) desejada das gentes. Minas Gerais, Belo Horizonte, v. 22, n. 1126, 15 jul. 1989, p. 6. Suplemento Literário.

- Paródia e pastiche no romance pós-moderno. Minas Gerais, Belo Horizonte, v. 24, n. 1160, 2 fev. 1991, p. 13. Suplemento Literário.

Autran Dourado. In: RICCIARDI, Giovanni. Auto-Retratos. São Paulo: Martins Fontes, 1991, p. 227-244.

. Os Sinos da Agonia, romance pós-moderno. Conferência pronunciada na Sorbonne em 17 de novembro de 1992. Revista USP, n. 20, 1994, p. 119-124.

. Depoimento. In: SOUZA, Eneida Maria (Org.). Autran Dourado. Belo Horizonte: Centro de Estudos Literários da UFMG; Curso de Pós-Graduação 
em Letras - Estudos Literários, 1996, p. 27-51. Coleção Encontro com Escritores Mineiros/2.

. Autran Dourado diz que escrever não dá prazer e é uma fatalidade. Entrevista a Julián Fuks. Folha de S. Paulo, 30 jul. 2005.

. O Senhor das Horas descreve processo de criação. Entrevista a Ubiratan Brasil. Bem Paraná, 30 out. 2007.

. Depoimento a Edla van Steen. In: STEEN, Edla van. Viver \& Escrever. Vol. 3. 2.ed. Porto Alegre: L\&PM, 2008, p. 169-178.

\section{Obras sobre Autran Dourado}

BOTTINO, Renata Christovão. Autran Dourado Leitor: Tempo de Amar e Ópera de Fantoches. Dissertação (Mestrado em Estudos de Literatura). Orientadora: Profa. Dra. Eliana Lucia M. Yunes Garcia. Rio de Janeiro: PUC-Rio, 2005.

BRASIL, Assis. O romancista Autran Dourado. Minas Gerais, Belo Horizonte, v. 5, n. 216, 17 out. 1970, p. 3. Suplemento Literário.

O Risco do Bordado. Minas Gerais, Belo Horizonte, v. 5, n. 223, 5 dez. 1970, p. 7. Suplemento Literário.

CAMARGO, Maria Stella. Linguagem e silêncio na obra de Autran Dourado. Dissertação (Mestrado em Literatura Brasileira). Rio de Janeiro: PUC-RJ, 1973. CAMPOS, Maria Consuelo da Cunha. A teia e o labirinto: Uma leitura da ficção de Autran Dourado. Tese (Doutorado). Rio de Janeiro: PUC-RJ, 1978.

CARNEIRO, Silvia Maria Ximenes. A técnica ficcional de Autran Dourado. Dissertação (Mestrado em Literatura Brasileira). Rio de Janeiro: UFRJ, Faculdade de Letras, 1975.

CARNEIRO, Sônia Marques Joaquim. A matéria de construção em Autran Dourado. Dissertação (Mestrado). São Paulo: UNESP, Faculdade de Letras. 1993.

COSTA, Thalita Silveira da. O oficio e a glória: Manifestações do trágico em textos de Autran Dourado. Dissertação (Mestrado). Rio de Janeiro: UFF, 1981. 
CRISTOVÃO, Fernando. Armas e Corações. Colóquio/Letras, Lisboa, jan. 1980, p. 95-97.

FABIANI, Marcelo Villela. A Tradição Poética de Autran Dourado em Ópera dos Mortos. Dissertação (Mestrado em Letras Vernáculas - Literatura Brasileira). Orientador: Prof. Dr. Godofredo de Oliveira Neto. Rio de Janeiro: UFRJ, 2011.

FONSECA, Laura Goulart. Nos Labirintos da Memória: A Poética de Autran Dourado em Os Sinos da Agonia e Ópera dos Mortos. Tese (Doutorado em Ciência da Literatura - Teoria Literária). Orientador: Prof. Dr. Manuel Antônio de Castro. Rio de Janeiro: UFRJ, 2007.

LAFETÁ, João Luiz. Uma Fotografia na Parede. In:__ (Org.). Os Melhores Contos de Autran Dourado. São Paulo: Global, 1997, p. 7-14.

LAURIA, Márcio José. O Risco do Bordado (com notória ajuda do riscadorbordador). Minas Gerais, Belo Horizonte, v. 10, n. 481, 6 dez. 1975, p. 10. Suplemento Literário.

LEPECKI, Maria Lúcia. Autran Dourado: Uma Leitura Mítica. São Paulo: Quíron, 1976.

LORENZ, Günter. Autran Dourado e o sofrimento na renúncia. Minas Gerais, Belo Horizonte, v. 22, n. 1076, 6 jun. 1987, p. 2. Suplemento Literário.

LUCAS, Fábio. A fiç̧ão de Fernando Sabino e Autran Dourado. In: SEMINÁRIO DE FICÇÃO, 2, 1983, Belo Horizonte. De Guimarães Rosa aos nossos dias. Belo Horizonte: Conselho Estadual de Cultura de Minas Gerais, 1983.

. Memórias contadas ao espelho: Darcy Ribeiro e Autran Dourado. In: 2o CONGRESSO ABRALIC, 1, 1990, Belo Horizonte. Anais... Belo Horizonte: UFMG, 1991, p. 594-613.

. A narrativa de Autran Dourado. Colóquio-Letras, Lisboa, n. 9, set. 1972, p. 17-24.

. O Risco do Bordado. Colóquio-Letras, Lisboa, n. 3, set. 1971, p. 90-91.

. O sete-estrelo de Autran Dourado. In: . A face visível. Rio de Janeiro: José Olympio, 1973, p. 137-143. 
NÓBREGA, Francisca Maria do Nascimento. O Risco do Bordado: A marca do homem. Dissertação (Mestrado em Teoria Literária). Rio de Janeiro: UFRJ, Faculdade de Letras, 1977.

PÓLVORA, Hélio. Autran Dourado. In: __. A força da ficção. Petrópolis: Vozes, 1971, p. 106-113.

PORTELLA, Eduardo. Dois acentos rítmicos do conto. In: . Dimensões II. Rio de Janeiro: Agir, 1959, p. 125-137.

RESENDE, Vânia Maria. A infância na obra O Risco do Bordado, de Autran Dourado. In: O Menino na Literatura Brasileira. São Paulo: Perspectiva, 1988, p. 47-51.

RIEDEL, Dirce Cortes. Proposições para a leitura de O risco do bordado. In: . Viver literatura: Ensaios e artigos. Organização Ana Cláudia Viegas. Rio de Janeiro: Eduerj, 2009, p. 121-132.

SANTIAGO, Silviano. Autran Dourado: Questão de perspectiva. Minas Gerais, Belo Horizonte, v. 20, n. 955, 19 jan. 1985, p. 7-8. Suplemento Literário. Reproduzido em: . Nas malhas da letra. São Paulo: Companhia das Letras, 1989, p.159-164.

. Minas, o mínimo universo de Autran. Minas Gerais, Belo Horizonte, v. 22, n. 1094, 20 fev. 1988, p. 5. Suplemento Literário.

. Mineiro Autran Dourado produziu uma narrativa original e cosmopolita. $O$ Estado de S. Paulo, 06 outubro 2012.

SANTOS, Leonor da Costa. Autran Dourado em romance puxa romance ou a ficção recorrente. Tese (Doutorado em Letras Vernáculas - Literatura Brasileira). Orientador: Prof. Dr. Wellington de Almeida Santos. Rio de Janeiro: UFRJ, Faculdade de Letras, 2008.

SCHÜLER, Donaldo. O Risco do Bordado. Minas Gerais, Belo Horizonte, v. 15, n. 844, 4 dez. 1982, p. 9. Suplemento Literário.

SOUZA, Eneida Maria de. A Barca dos Homens: A viagem e o rito. Dissertação (Mestrado em Literatura Brasileira). Rio de Janeiro: PUC-RJ, 1975. 
Autran Dourado e o romance - I, II e III. Minas Gerais, Belo Horizonte, v. 8 , n. 370,29 set. 1973 , p. $2-3$; v. 8 , n. 371,6 out. 1973 , p. 4-5; v. 8, n. 372,13 out. 1973, p. 8-9. Suplemento Literário.

A glória de um ofício: Uma poética da criação. Minas Gerais, Belo Horizonte, v. 9, n. 432, 7 dez. 1974, p. 4-5. Suplemento Literário.

- Do rito ao romance: A Barca dos Homens. Ensaios de Semiótica: Cadernos de Lingüística e Teoria da Literatura. Belo Horizonte: UFMG, n. 14, dez. 1985, p. 25-56.

. Traços de aranha. In: . Tempo de pós-crítica, Cadernos de Pesquisa, Belo Horizonte, NAPq/FALE/UFMG, n. 20, nov. 1994, p. 32-36.

Setenta anos de ficção. Minas Gerais, Belo Horizonte, n. 12, abr. 1996, p. 3. Suplemento Literário.

(Org.). As minas de Autran Dourado. Minas Gerais, Belo Horizonte, 19 jan. 1985. Suplemento Especial.

(Org.). Autran Dourado. Belo Horizonte: Centro de Estudos Literários da UFMG; Curso de Pós-Graduação em Letras - Estudos Literários, 1996. Coleção Encontro com Escritores Mineiros/2.

SOUZA, Ronaldes de Melo e. Agonia e Morte em Autran Dourado. In:

Ensaios de Poética e Hermenêutica. Rio de Janeiro: Oficina Raquel, 2010, p. 163-182.

TIIHONEN, Lasse Tapani. Imagética, Alegoria e Simbolismo: sua função na criação de um universo mítico-poético em duas obras de Autran Dourado. Tese (Doutorado). Ann Arbor: University Microfilms International, 1983.

\section{Outras obras consultadas}

ACOSTA CRUZ, Maria Isabel. The Discourse of Excess: The Latin American Neobaroque and James Joyce. Ann Arbor: University Microfilms International, 1986.

ALLEMANN, Beda. Ironia e Poesia. Tradução Giorgio Voghera. Milano: Mursia, 
1971.

ALLOTT, Miriam. Los novelistas y la novela. Traducción de R. B. Costa y María Luisa Borrás. Barcelona: Editorial Seix Barral, 1966.

ALTER, Robert. Partial Magic: The Novel as a Self-Conscious Genre. Berkeley: University of California Press, 1975.

ANAXIMANDRO, PARMÊNIDES, HERÁCLITO. Os Pensadores Originários. Tradução Emmanuel Carneiro Leão \& Sérgio Wrublewski. Petrópolis: Vozes, 1991.

ANDRADE, Carlos Drummond de. Reunião: Dez livros de poesia. Introdução de Antônio Houaiss. Rio de Janeiro: José Olympio, 1969.

ARISTÓTELES. Poética. 3.ed. Tradução, Prefácio, Introdução, Comentário e Apêndices de Eudoro de Sousa. Lisboa: Imprensa Nacional - Casa da Moeda, 1992.

AUERBACH, Erich. Mimesis. Tradução G. B. Sperber. São Paulo: Perspectiva, 1971. Sobretudo, o cap. 18 "Na Mansão de La Mole" (p. 405-441) e o cap. 20 "A Meia Marrom" (p. 471-498).

ÁVILA, Affonso. O Lúdico e as Projeções do Mundo Barroco. São Paulo: Perspectiva, 1980.

BACHELARD, Gaston. A Poética do Espaço. Tradução Antonio de Padua Danesi. São Paulo: Martins Fontes, 1989a.

- A Água e os Sonhos: Ensaio sobre a imaginação da matéria. Tradução Antonio de Paula Danesi. São Paulo: Martins Fontes, 1989b.

- A Psicanálise do Fogo. Tradução Paulo Neves. São Paulo: Martins Fontes, 1994.

BAKHTIN, Mikhail. Problemas da Poética de Dostoiévski. 5.ed. revista. Tradução Paulo Bezerra. Rio de Janeiro: Forense Universitária, 2010. . Estética da Criação Verbal. Tradução Paulo Bezerra. São Paulo: Martins Fontes, 2003. 
Epos e Romance. In: . Questões de Literatura e de Estética: A Teoria do Romance. Tradução Aurora Fornoni Bernardini et al. São Paulo: Editora UNESP/HUCITEC, 1988, p. 397-428.

BALLESTER, Gustavo Torrente. El Quijote como Juego. Madrid: Guadarrama, 1975.

BEACH, Joseph Warren. The Twentieth-Century Novel: Studies in Technique. New York: The Century Co., 1932. Sobretudo, os capítulos II ("Exit Author", p. 14-24) e XII a XIX (Part Two: The Dramatic Ideal, p. 119-228).

BEJA, Morris. Epiphany in the Modern Novel. Seatle: University of Washington Press, 1971.

BELLEl, Sérgio Luiz Prado. Theory of the novel: Henry James. Florianópolis: Pós-graduação em Inglês / UFSC, 1998.

BENJAMIN, Walter. Origem do Drama Barroco Alemão. Tradução, apresentação e notas Sérgio Paulo Rouanet. São Paulo: Brasiliense, 1984.

BERGSON, Henri. Matéria e Memória: Ensaio sobre a relação do corpo com o espírito. Tradução Paulo Neves da Silva. São Paulo: Martins Fontes, 1990.

BLANCHOT, Maurice. O Espaço Literário. Tradução Álvaro Cabral. Rio de Janeiro: Rocco, 1987. Sobretudo, "A solidão essencial" (p. 9-25) e "A Literatura e a Experiência Original” (p. 209-249).

BOLLÈME, Geneviève. La Leçon de Flaubert. Essai. Paris: Julliard, 1964.

BOOTH, Wayne C. The Rhetoric of Fiction. Chicago: University of Chicago Press, 1961.

BRADBURY, Malcolm \& McFARLANE, James (Orgs.). Modernismo: Guia Geral (1890-1930). Tradução Denise Bottmann. São Paulo: Companhia das Letras, 1989.

BRADBURY, Malcolm. O Mundo Moderno: Dez Grandes Escritores. Tradução Paulo Henriques Britto. São Paulo: Companhia das Letras, 1989.

CALABRESE, Omar. A Idade Neobarroca. Tradução Carmen de Carvalho e Artur Morão. São Paulo: Martins Fontes, 1988. 
CAMPOS, Haroldo de. Ruptura dos Gêneros na Literatura Latino-Americana. In: MORENO, César Fernández (Coord.). América Latina em sua Literatura. Tradução Luiz João Gaio. São Paulo: Perspectiva, 1979, p. 281-305.

CASALDUERO, Joaquín. Sentido y Forma de las Novelas Ejemplares. Buenos Aires: Revista de Filologia Hispánica, 1943.

CERVANTES, Miguel de. Don Quijote de La Mancha. Textos y notas de Martín de Riquer. Barcelona: Juventud, 1983.

O Engenhoso Fidalgo Dom Quixote de La Mancha. 2.ed. Tradução e notas Eugênio Amado. Ilustrações Gustave Doré. Belo Horizonte: Itatiaia, 1984, 2 vols.

. Novelas Exemplares. Tradução Ernani Ssó. São Paulo: Cosac Naify, 2015.

CHAYES, Irene Hendry. Joyce's Epiphanies. In: CONNOLLY, Thomas E. (Ed.). Joyce's Portrait: Criticisms \& Critiques. New York: Appleton-Century-Crofts, 1962, p. 204-220.

As epifanias de Joyce. Tradução Bernardina da Silveira Pinheiro. Letra Freudiana - Retratura de Joyce: Uma perspectiva lacaniana, Rio de Janeiro, ano XII, n. 13, 1993, p. 120-128.

COHN, Dorrit. Narrated monologue: definition of a fictional style. Comparative Literature, v. 18, n. 2, spring 1966, p. 97-112.

. Part I - Consciousness in Third-Person Context: 3. Narrated Monologue. In: __. Transparent Minds: Narrative Modes for Presenting Consciousness in Fiction. Princeton, New Jersey: Princeton University Press, 1978, p. 99-140. - The Encirclement of Narrative: On Franz Stanzel's Theorie des Erzählens. Poetics Today (1981) 2: 157-182.

CONNOLLY, Thomas E. (Ed.). Joyce's Portrait: Criticisms \& Critiques. New York: Appleton-Century-Crofts, 1962.

CONNOLLY, Thomas E. Joyce's Aesthetic Theory. In: CONNOLLY, Thomas E. (Ed.). Joyce's Portrait: Criticisms \& Critiques. New York: Appleton-CenturyCrofts, 1962, p. 266-271. 
COUTINHO, Afrânio. O Barroco. In: Do Barroco: Ensaios. Rio de Janeiro: Editora UFRJ; Tempo Brasileiro, 1994, p. 235-283.

DE ANGELIS, Palmira. L'Immagine Epifanica. Hopkins, D'Annunzio, Joyce: Momenti di uma poetica. Roma: Bulzoni Editore, 1989.

DUARTE, Lélia Parreira (Org.). A Escrita da Finitude de Orfeu e de Perséfone. Belo Horizonte: Veredas \& Cenários, 2009.

ECO, Umberto. Obra Aberta: Forma e indeterminação nas poéticas contemporâneas. Tradução Giovanni Cutolo. São Paulo: Perspectiva, 1969.

. Sobre uma noção joyceana [Epifania]. In: BUTOR, Michel, SVEVO, Italo et alii. Joyce e o romance moderno. Tradução T. C. Netto. São Paulo: Documentos, 1969, p. 53-63.

. Las Poéticas de Joyce. Traducción de Helena Lozano. 4.ed. Barcelona: Editorial Lumen, 2000.

EDEL, Leon. Novel and Camera. In: HALPERIN, John (Ed.). The Theory of the Novel: New essays. New York: Oxford University Press, 1974, p. 177-188.

. Henry James. Tradução Alex Severino. São Paulo: Livraria Martins, 1963.

ELIOT, T. S. Ulisses, Ordem e Mito. Tradução Claudia de Moraes Rego. Escola Letra Freudiana - A Jornada de Ulisses, Rio de Janeiro, ano XX, n. 28, 2001, p. 59-61.

ELIADE, Mircea. Mito e Realidade. Tradução Pola Civelli. 5.ed. São Paulo: Perspectiva, 1998.

ÉSQUILO. Oréstia: Agamêmnon, Coéforas, Eumênides. Tradução do grego, introdução e notas Mário da Gama Kury. Rio de Janeiro: Jorge Zahar, 1991.

EURÍPIDES. As Bacantes. Introdução, tradução e comentário de Eudoro de Sousa. São Paulo: Duas Cidades, 1974.

_. Ifigênia em Áulis, As Fenícias, As Bacantes. Tradução do grego, introdução e notas Mário da Gama Kury. 3.ed. Rio de Janeiro: Jorge Zahar, 1993.

FINK, Eugen. Le Jeu comme Symbole du Monde. Traduit de l'allemand par Hans Hildenbrand et Alex Lindenberg. Paris: Les Éditions de Minuit, 1966. 
FIORIN, José Luiz. Polifonia textual e discursiva. In: BARROS, Diana Luz Pessoa de \& FIORIN, José Luiz (Orgs.). Dialogismo, polifonia, intertextualidade. São Paulo: Edusp, 1994, p. 29-36.

FLAUBERT, Gustave. Madame Bovary. Tradução, apresentação e notas Fúlvia M. L. Moretto. São Paulo: Nova Alexandria, 2007.

A Educação Sentimental. Tradução João Barreira. São Paulo: Martin Claret, 2006.

. Cartas Exemplares. Tradução Carlos Eduardo Lima Machado. Rio de Janeiro: Imago, 2005.

Préface à la vie d'écrivain ou Extraits de la correspondance. Présentation et choix de Geneviève Bollème. Paris: Seuil, 1963.

FOUCAULT, Michel. As Palavras e as Coisas: Uma Arqueologia das Ciências Humanas. 5.ed. Tradução Salma Tannus Muchail. São Paulo: Martins Fontes, 1990. Sobretudo, "Las Meninas" (p. 19-31) e "Representar: I. Dom Quixote" (p. 61-65).

FRAISSE, Luc. Le Processus de la Création chez Marcel Proust: Le Fragment Expérimental. Paris: José Corti, 1988.

FRIEDRICH, Hugo. Estrutura da Lírica Moderna: da metade do século XIX a meados do século XX. Tradução do texto por Marise M. Cuorini; tradução das poesias por Dora F. da Silva. São Paulo: Duas Cidades, 1978.

FUENTES, Carlos. Cervantes ou a Crítica da Leitura. In: Eu e os Outros: Ensaios Escolhidos. Tradução Sergio Flaksman. Rio de Janeiro: Rocco, 1989, p. 65-90.

FRIEDMAN, Melvin J. Stream of Consciousness: A Study in Literary Method. New Haven: Yale University Press, 1955.

GADAMER, Hans-Georg. Hans-Georg Gadamer. Wahrheit und Methode: Grundzüge einer philosophischen Hermeneutik. 6. Aufl. Tübingen: J.C.B. Mohr (Paul Siebeck), 1990.

- Verdade e Método: Traços Fundamentais de uma Hermenêutica Filosófica. Tradução Flávio Paulo Meurer. Petrópolis: Vozes, 1997. 
- Verdade e Método II: Complementos e índice. Tradução Enio Paulo Giachini. Petrópolis: Vozes, 2002.

A Atualidade do Belo: A Arte como Jogo, Símbolo e Festa. Tradução Celeste Aida Galeão. Rio de Janeiro: Tempo Brasileiro, 1985.

- Hermenêutica da Obra de Arte. Seleção e tradução Marco Antonio Casanova. São Paulo: WMF Martins Fontes, 2010.

. Os caminhos de Heidegger. In: Hegel - Husserl - Heidegger.

Tradução Marco Antonio Casanova. Petrópolis, RJ: Vozes, 2012, p. 235-445.

GENETTE, Gérard. Figures III. Paris: Éditions du Seuil, 1972.

. Discurso da Narrativa. Tradução Fernando Cabral Martins. Lisboa: Vega, s.d.

GOETHE, J. W. Poemas. 2.ed. corrigida e aumentada. Antologia, versão portuguesa, notas e comentários de Paulo Quintela. Coimbra: Por Ordem da Universidade, 1958.

GRASSI, Ernesto. Arte e Mito. Tradução Manuela Pinto dos Santos. Lisboa: Edição Livros do Brasil, s.d.

A condenação da Arte. Platão. In: Arte como Antiarte. Tradução Antonieta Scarabelo. São Paulo: Duas Cidades, 1975, p. 91-117.

. Poder da Imagem: Impotência da Palavra Racional. Tradução Henriqueta Ehlers e Rubens Siqueira Bianchi. São Paulo: Duas Cidades, 1978.

GUILEAD, Reuben. Être et Liberté (Une étude sur le dernier Heidegger). Louvain: Éditions Nauwelaerts, 1965.

HAMBURGER, Käte. A Lógica da Criação Literária. Tradução Margot P. Malnic. São Paulo: Perspectiva, 1975.

HATZFELD, Helmut. Estudos sobre o Barroco. Tradução Célia Berrettini. São Paulo: Perspectiva/EDUSP, 1988. Sobretudo, "Barroco Literário e Barroco Artístico Comparados: Cervantes e Velázquez" (p. 239-255) e "Cervantes e o Barroco" (p. 257-270). 
El "Quijote" como Obra de Arte del Lenguaje. 2ª edición española refundida y aumentada. Madrid: Consejo Superior de Investigaciones Científicas / Revista de Filologia Española - Anejo LXXXIII, 1972.

HEIDEGGER, Martin. Sein und Zeit. Frankfurt am Main: Vittorio Klostermann, 1977. Gesamtausgabe, Band 2.

- Sobre o Humanismo. Introdução, tradução e notas Emmanuel Carneiro Leão. Rio de Janeiro: Tempo Brasileiro, 1967.

Introdução à metafísica. Apresentação e tradução Emmanuel Carneiro Leão. Rio de Janeiro: Tempo Brasileiro, 1987.

- Heráclito (A Origem do Pensamento Ocidental. Lógica. A Doutrina do Lógos). Tradução Márcia de Sá Cavalcante Schuback. Rio de Janeiro: Relume Dumará, 1988a.

. Ser e Tempo - Parte I. Tradução Márcia de Sá Cavalcante. Petrópolis: Vozes, 1988b.

- Ser e Tempo - Parte II. Tradução Márcia de Sá Cavalcante. Petrópolis: Vozes, 1989a.

- Identidade e Diferença. In: Conferências e Escritos Filosóficos. Tradução e notas Ernildo Stein. São Paulo: Nova Cultural, 1989b, p. 137-162. Coleção Os Pensadores.

Hölderlin y la esencia de la poesía. In: Arte y poesía. Traducción y prólogo de Samuel Ramos. México: Fondo de Cultura Económica, 1992, p. 125-148.

. Nietzsche: Metafísica e Niilismo. Tradução Marco Antonio Casa Nova. Rio de Janeiro: Relume Dumará, 2000.

. A palavra de Nietzsche "Deus morreu" (1943). Tradução Alexandre Franco de Sá. In: _. Caminhos de Floresta. Tradução Irene Borges-Duarte, Filipa Pedroso, Alexandre Franco de Sá et al. Lisboa: Fundação Calouste Gulbenkian, 2002a, p. 241-305.

. Ensaios e conferências. Tradução Emmanuel Carneiro Leão, Gilvan Fogel \& Márcia Sá Cavalcante Schuback. Petrópolis, RJ: Vozes, 2002b. Sobretudo, 
“... poeticamente o homem habita..." (p. 165-181) e "No azul sereno..." (p. 254259).

A Caminho da Linguagem. Tradução Márcia Sá Cavalcante Schuback. Petrópolis: Vozes, 2003.

. Nietzsche I. Tradução Marco Antônio Casanova. Rio de Janeiro: Forense Universitária, 2007a.

. Nietzsche II. Tradução Marco Antônio Casanova. Rio de Janeiro: Forense Universitária, 2007b.

Marcas do caminho. Tradução Enio Paulo Giachini e Ernildo Stein. Petrópolis: Vozes, 2008. Sobretudo, "A essência da verdade (1930)" (p. 189214) e "A teoria platônica da verdade (1931/1932, 1940)" (p. 215-250).

A Origem da Obra de Arte. Edição bilíngüe. Tradução Idalina Azevedo e Manuel António de Castro. São Paulo: Edições 70, 2010.

HELLER, Erich. Thomas Mann: The ironic german. Indiana: Regnery / Gateway, 1958.

HERNADI, Paul. Dual perspective: Free indirect discourse and related techniques. Comparative Literature (1972) 24: 32-43.

HIGHET, Gilbert. La Tradición Clasica: Influencias Griegas y Romanas en la Literatura Occidental. México: F. C. E., 1978, 2 vols.

HÖLDERLIN, Friedrich. Reflexões. Tradução Márcia de Sá Cavalcante e Antonio Abranches. Rio de Janeiro: Relume-Dumará, 1994.

HOMERO. Ilíada. Tradução Manuel Odorico Mendes. São Paulo: Martin Claret, 2003.

. Odisseia. Tradução Manuel Odorico Mendes. São Paulo: Martin Claret, 2002.

HUIZINGA, Johan. Homo Ludens: O jogo como elemento da cultura. Tradução João Paulo Monteiro. São Paulo: Perspectiva / EDUSP, 1971.

HUMPHREY, Robert. O Fluxo da Consciência: Um Estudo sobre James Joyce, Virgínia Woolf, Dorothy Richardson, William Faulkner e outros. Tradução Gert Meyer. São Paulo: McGraw-Hill do Brasil, 1976. 
HUSSERL, Edmund. A Crise das Ciências Europeias e a Fenomenologia Transcendental: Uma Introdução à Filosofia Fenomenológica. Tradução Diogo Falcão Ferrer. Rio de Janeiro: Forense Universitária, 2012.

ISER, Wolfgang. O Ato da Leitura (Uma Teoria do Efeito Estético). Tradução Johannes Kretschmer. São Paulo: Editora 34, 1996 (vol. 1) e 1999 (vol. 2).

- The Implied Reader (Patterns of communication in Prose Fiction from Bunyan to Beckett). Baltimore: The Johns Hopkins University Press, 1974.

A Interação do Texto com o Leitor. In: LIMA, Luiz Costa (Org.). A Literatura e o Leitor. Rio de Janeiro: Paz \& Terra, 1979, p. 83-132.

JAEGER, Werner. Paidéia: A Formação do Homem Grego. Tradução Artur M. Parreira. São Paulo: Martins Fontes; Brasília: Editora da Unb, 1989.

JAMES, Henry. The Art of the Novel: Critical Prefaces. Edited by Richard P. Blackmur. Boston: Northeastern University Press, 1984.

- A Arte do Romance: Antologia de Prefácios. Organização, tradução e notas Marcelo Pen. São Paulo: Globo, 2003.

. A Arte da Ficção. Tradução Daniel Piza. Seleção e apresentação Antônio Paulo Graça. São Paulo: Imaginário, 1995.

. Gustave Flaubert. Tradução Léa Viveiros de Castro. Rio de Janeiro: 7Letras, 2000.

. Os Embaixadores. Tradução Marcelo Pen. São Paulo: Cosac Naify, 2010.

. A Taça de Ouro. Tradução Alves Calado. Rio de Janeiro: Record, 2002.

. As Asas da Pomba. Tradução Marcos Santarrita. Rio de Janeiro: Ediouro, 1998.

. The Awkward Age. New York: W. W. Norton \& Company, 1969.

- Pelos Olhos de Maisie. Tradução Paulo Henriques Britto. São Paulo: Companhia das Letras, 1994.

JAUSS, Hans Robert. A História da Literatura como Provocação à Teoria Literária. Tradução Sérgio Tellarolo. São Paulo: Ática, 1994.

Aesthetic Experience and Literary Hermeneutics. Minneapolis: University 
of Minnesota Press, 1982.

La dialettica fra io che ricorda e io ricordato. In: Tempo e ricordo nella Recherche di Marcel Proust. Traduzione di Matteo Galli. Firenze: Le Lettere, 2003, p. 113-147.

JOYCE, James. Ulisses. Tradução Antônio Houaiss. São Paulo: Abril Cultural, 1980.

. Stephen Herói. Tradução José Roberto O'Shea. São Paulo: Hedra, 2012.

- Um retrato do artista quando jovem. Tradução Bernardina Silveira Pinheiro. São Paulo: Siciliano, 1992.

- Dublinenses. 3.ed. Tradução Hamilton Trevisan. Rio de Janeiro: Civilização Brasileira, 1984.

. Finnegans Wake / Finnicius Revém. 5 vols. Edição bilíngüe. Introdução, versão e notas Donaldo Schüler. São Paulo: Ateliê Editorial, 1999-2003.

. Epifanias. Tradução Bernardina da Silveira Pinheiro. Letra Freudiana Retratura de Joyce: Uma perspectiva lacaniana, Rio de Janeiro, ano XII, n. 13, 1993, p. 112-119.

. Epifanias. Tradução e introdução Piero Eyben. São Paulo: lluminuras, 2012.

JÚNIOR, Sebastião Rios Corrêa. Perspectiva narrativa no romance contemporâneo. Cerrados, Brasília, n. 5, ano r, 1996, p. 161-177.

JUNKES, Lauro. Romancistas e a teoria do romance. Anuário de Literatura, Florianópolis, 1997, p. 131-158.

KENNER, Hugh. The Portrait in Perspective. In: CONNOLLY, Thomas E. (Ed.). Joyce's Portrait: Criticisms \& Critiques. New York: Appleton-Century-Crofts, 1962, p. 25-60.

. O Retrato em perspectiva. Tradução Paulo Henriques Britto. Letra Freudiana - Retratura de Joyce: Uma perspectiva lacaniana, Rio de Janeiro, ano XII, n. 13, 1993, p. 90-110.

KERÉNYI, KCarl. Dioniso: Imagem Arquetípica da Vida Indestrutível. Tradução Ordep Trindade Serra. São Paulo: Odysseus, 2002. 
\& JUNG, C. G. A Criança Divina: Uma introdução à essência da mitologia. Tradução Vilmar Schneider. Petrópolis, RJ: Vozes, 2011.

KRISTEVA, Julia. A Palavra, o Diálogo e o Romance. In: Introdução à Semanálise. Tradução Lúcia Helena França Ferraz. São Paulo: Perspectiva, 1974, p. 61-90.

KUNDERA, Milan. A Arte do Romance: Ensaios. Tradução Teresa Bulhões C. Da Fonseca \& Vera Mourão. Rio de Janeiro: Nova Fronteira, 1988.

LANSER, Susan Sniader. The Narrative Act: Point of View in Prose Fiction. Princeton: Princeton University Press, 1981.

LEÃO, Emmanuel Carneiro. O pensamento originário. In: ANAXIMANDRO, PARMÊNIDES, HERÁCLITO. Os pensadores originários. Texto e tradução Emmanuel Carneiro Leão \& Sérgio Wrublewski. Petrópolis: Vozes, 1991, 7-17.

. Existência e Poesia. In: RILKE, Rainer Maria. Sonetos a Orfeu e Elegias de Duíno. Tradução e introdução de Emmanuel Carneiro Leão. Petrópolis: Vozes, 1989, p. 7-18.

LEVIN, Harry. James Joyce: Introducción crítica. Traducción de Antonio Castro Leal. 2.ed. México: Fondo de cultura Económica, 1973.

LLOSA, Mario Vargas. A orgia perpétua: Flaubert e Madame Bovary. Tradução Remy Gorga, Filho. Rio de Janeiro: Francisco Ales, 1979.

LOBO, Luiza. A ficção impressionista e o fluxo de consciência. In: . Crítica sem juízo. Rio de Janeiro: Francisco Alves, 1993, p. 37-47.

LUBBOCK, Percy. A Técnica da Fiç̧ão. Tradução Octávio Mendes Cajado. São Paulo: Cultrix / EDUSP, 1976.

MAGNY, Claude-Edmonde. L'age du romain américain. Paris: Seuil, 1948.

MAUROIS, André. A busca do tempo perdido. In: Em busca de Marcel Proust. Tradução Leonardo Fróes. São Paulo: Siciliano, 1995, p. 145-172.

MENDILOW, A. A. O Tempo e o Romance. Tradução Flávio Wolf. Porto Alegre: Globo, 1972.

MERLEAU-PONTY, Maurice. Fenomenologia da Percepção. Tradução Carlos Alberto Ribeiro de Moura. São Paulo: Martins Fontes, 1994. 
MEYERHOFF, Hans. O Tempo na Literatura. Tradução Myriam Campello. São Paulo: McGraw-Hill do Brasil, 1976.

MIELIETINSKI, E. M. A Poética do Mito. Tradução Paulo Bezerra. Rio de Janeiro: Forense Universitária, 1987.

MONEGAL, Emir Rodríguez. Tradição e Renovação. In: MORENO, César Fernández (Coord.). América Latina em sua Literatura. Tradução Luiz João Gaio. São Paulo: Perspectiva, 1979, p. 131-159.

. Borges: uma Poética da Leitura. Tradução Irlemar Chiampi. São Paulo: Perspectiva, 1980.

MOURA, Carlos Alberto Ribeiro de. Crítica da Razão na Fenomenologia. São Paulo: Nova Estella / EDUSP, 1989.

NATELLA, Aristides. Reflexiones sobre el neobarroco en la ficción hispanoamericana de la actualidad. In: El Barroco en América. XVII Congreso del Instituto Internacional de Literatura Iberoamericana. Madrid: Cultura Hispánica, 1978, p. 337-385.

NEUHAUS, Volker. Romane der "Vielpersonigen Bewußtseinsdarstellung". In: . Typen Multiperspektivischen Erzãhlens. Köln: Böhlau-Verlag, 1971, p. 118-144. Sobre Henry James e William Faulkner.

NIETZSCHE, Friedrich. O nascimento da tragédia ou Helenismo e pessimismo. Tradução, notas e posfácio J. Guinsburg. São Paulo: Companhia das Letras, 1992.

- Genealogia da moral. Tradução, notas e posfácio Paulo César de Souza. São Paulo: Companhia das Letras, 1998.

- A visão dionisíaca do mundo. Tradução Marcos Sinésio Pereira Fernandes \& Maria Cristina dos Santos de Souza. São Paulo: Martins Fontes, 2005.

. Filosofia na era trágica dos gregos. Tradução e apresentação Gabriel Valladão Silva. Porto Alegre: L\&PM, 2011a.

A vontade de poder. Tradução Marcos Sinésio Pereira Fernandes \& Francisco José Dias de Moraes. Apresentação Gilvan Fogel. Rio de Janeiro: Contraponto, 2008. 
Assim falou Zaratustra: Um livro para todos e para ninguém. Tradução, notas e posfácio Paulo César de Souza. São Paulo: Companhia das Letras, $2011 b$.

NUNES, Benedito. Hermenêutica e Poesia: O Pensamento Poético. Organizado por Maria José Campos. Belo Horizonte: Editora UFMG, 1999.

ORTEGA Y GASSET, José. A Desumanização da Arte. 3.ed. Tradução Ricardo Araújo. São Paulo: Cortez, 2001.

OROZCO DÍAZ, Emílio. Manierismo y Barroco. Madrid: Cátedra, 1975.

OTTO, Walter Friedrich. Dioniso: Mito y Culto. 3.ed. Traducción de Cristina García Ohlrich. Madrid: Ediciones Siruela, 2006.

. Os deuses da Grécia: A imagem do divino na visão do espírito grego. Tradução Ordep Serra. São Paulo: Odysseus Editora, 2005.

PALMER, Richard. Hermenêutica. Tradução Maria Luísa Ribeiro Ferreira. Lisboa: Edições 70, 1989.

PAREYSON, Luigi. Estética: Teoria da Formatividade. Tradução Ephraim Ferreira Alves. Petrópolis: Vozes, 1993.

. Problemas da Estética. Tradução Maria Helena Nery Garcez. São Paulo: Martins Fontes, 1984.

PASCAL, Roy. Gustave Flaubert: Madame Bovary. In: . The Dual Voice:

Free Indirect Speech and its Functioning in the Nineteenth-Century European Novel. Manchester: Manchester University Press, 1977, p. 98-112.

PAZ, Octavio. O Arco e a Lira. Tradução Olga Savary. Rio de Janeiro: Nova Fronteira, 1982.

. Os Filhos do Barro: do romantismo à vanguarda. Tradução Olga Savary. Rio de Janeiro: Nova Fronteira, 1984. Poesia e Modernidade. In: . A Outra Voz. Tradução Vladir Dupont. São Paulo: Siciliano, 1993, p. 9-74.

PESSOA, Fernando. Obra Poética. Seleção, organização e notas Maria Aliete Galhoz. Rio de Janeiro: Nova Aguilar, 1986. 
PEYRE, Henri. A Literatura Simbolista. Tradução Maria Helena Nery Garcez e Maria Clara Rezende Teixeira Constantino. São Paulo: Cultrix/EDUSP, 1983.

PINHEIRO, Bernardina da Silveira. Ulisses: Uma paródia moderna da Odisseia. Escola Letra Freudiana - A Jornada de Ulisses, Rio de Janeiro, ano XX, n. 28, 2001, p. 15--29.

. Ulisses: Monólogo a três. Escola Letra Freudiana - A Jornada de Ulisses, Rio de Janeiro, ano XX, n. 28, 2001, p. 149-163.

. Sentimento de culpa em Stephen Dedalus: Freud/Lacan. Letra Freudiana - Retratura de Joyce: Uma perspectiva lacaniana, Rio de Janeiro, ano XII, n. 13, 1993, p. 183-189.

PIRANDELLO, Luigi. L'Umorismo. Milano: Arnaldo Mondadori, 1989.

PLATÃO. A República. Introdução, tradução e notas de Maria Helena da Rocha Pereira. Lisboa: Fundação Calouste Gulbekian, 1987.

PÖGGELER, Otto. A Via do Pensamento de Martin Heidegger. Tradução Jorge Telles de Menezes. Lisboa: Instituto Piaget, 2001.

POUILLON, Jean. O Tempo no Romance. Tradução Heloysa de Lima Dantas. São Paulo: Cultrix / EDUSP, 1974.

POULET, Georges. O Espaço Proustiano. Tradução Ana Luiza B. Martins Costa. Rio de Janeiro: Imago, 1992.

PROUST, Marcel. Em Busca do Tempo Perdido. Tradução Mario Quintana et al. 11.ed. São Paulo: Globo, 1992. 7 vols.

A propósito do "Estilo" de Flaubert [1920]. In: Nas Trilhas da Crítica. Tradução Plínio Augusto Coelho. São Paulo: EDUSP/Imaginário, 1994, p. 6585.

RAIMOND, Michel. La crise du roman: des lendemains du Naturalisme aux années vingt. Paris: José Corti, 1985.

REED, Walter L. The Counterfiction of Don Quixote. In: An Exemplary History of the Novel: The Quixotic versus the Picaresque. Chicago: The University of Chicago Press, 1981, p. 71-92.

REVISTA TEMPO BRASILEIRO, n. 62, jul.-set., 1980 . Dossiê "A Paródia". 
RIMBAUD, Arthur. Oeuvres complétes. Paris: Gallimard, 1951.

- Correspondência. Tradução, notas e comentários Ivo Barroso. Rio de Janeiro: Topbooks, 2009.

RICOEUR, Paul. A memória, a história, o esquecimento. Tradução Alain François et al. Campinas, SP: Editora da Unicamp, 2007.

ROGGIANO, Alfredo A. Acerca de dos barrocos: El de España y el de América. In: El Barroco en América. XVII Congreso del Instituto Internacional de Literatura Iberoamericana. Madrid: Cultura Hispánica, 1978, p. 39-48.

ROMBERG, Bertil. Studies in the Narrative Technique of the First Person Novel. Stockholm: Almquist \& Wiksell, 1962.

ROSENFELD, Anatol. Reflexões sobre o romance moderno. In: Texto e contexto. 4.ed. São Paulo: Perspectiva, 1985, p. 75-97.

. Thomas Mann: ironia e mito. In: . Doze Estudos. São Paulo: Conselho Estadual de Cultura, p. 93-98, s.d.

. Thomas Mann. São Paulo: Perspectiva / Editora USP; Campinas, SP: Editora da UNICAMP, 1994.

ROSENFIELD, Kathrin Holzermayr (Org.). Filosofia e Literatura: O Trágico. Rio de Janeiro: Jorge Zahar Editor, 2001.

ROSSUM-GUYON, Françoise van. Ponto de vista ou perspectiva narrativa: Teorias e conceitos críticos. In: ROSSUM-GUYON, Françoise van et alii. Categorias da narrativa. Lisboa: Arcádia, 1976, p. 21-59.

SÁ, Olga de. O termo e o conceito de epifania em Joyce. In: . A Escritura de Clarice Lispector. 2.ed. Petrópolis: Vozes, 1993, p. 168-192.

SARAIVA, António José. O Discurso Engenhoso: Estudos sobre Vieira e outros autores barrocos. São Paulo: Perspectiva, 1980.

SARDUY, Severo. O Barroco e o Neobarroco. In: MORENO, César Fernández (Coord.). América Latina em sua Literatura. Tradução Luiz João Gaio. São Paulo: Perspectiva, 1979, p. 161-178.

SCHOLES, Robert \& KELLOG, Robert. O Ponto de Vista na Narrativa. In: A Natureza da Narrativa. Tradução Gert Meyer. São Paulo: McGraw-Hill do 
Brasil, 1977, p. 169-198.

SCHOLES, Robert. Stephen Dedalus, poet or esthete? P.M.L.A., v. 79, 1964, p. 484-489.

SILVA, Robson André da. O Jogo da Ficção e da Realidade em Don Quijote de La Mancha. Dissertação (Mestrado em Teoria Literária). Orientador: Prof. Dr. Henryk Siewierski. Brasília: Universidade de Brasília, 2001.

SILVA, Vítor Manuel de Aguiar e. O romance. In: Teoria da Literatura. 3.ed. rev. e aum. Coimbra: Livraria Almedina, 1979, p. 247-346.

SÓFOCLES. A Trilogia Tebana: Édipo Rei, Édipo em Colono, Antígona. Tradução do grego, introdução e notas Mário da Gama Kury. 2.ed. Rio de Janeiro: Jorge Zahar, 1991.

SOUSA, Eudoro de. Dioniso em Creta e outros ensaios: Estudos de mitologia e filosofia da Grécia antiga. São Paulo: Duas Cidades, 1973.

SOUZA, Ronaldes de Melo e. O sentido da vida no fundo do inferno: A ideia do nada como condição de criação e metamorfose a partir da tragédia grega. Entrevista a Severino Francisco. Jornal de Brasília, Domingo, 31/03/1991, Caderno 2, p. 3.

. A Hermenêutica da Concriatividade. Rio de Janeiro: UFRJ, 1988.

. Epistemologia e hermenêutica em Bachelard. Tempo Brasileiro, Rio de Janeiro, n. 90, jul.-set., 1987, p. 47-93.

. Poesia e filosofia em Nietzsche. Poesia Sempre, Rio de Janeiro, ano 8, n. 13, dez. 2000, p. 247-251.

. Poética da narrativa de primeira pessoa. Revista Tempo Brasileiro, Rio de Janeiro, n. 171, out.-dez., 2007, p. 141-160.

. Atualidade da tragédia grega. In: Ensaios de poética e hermenêutica. Rio de Janeiro: Oficina Raquel, 2010, p. 53-83.

STAIGER, Emil. Conceitos Fundamentais da Poética. Tradução Celeste Aída Galeão. Rio de Janeiro: Tempo Brasileiro, 1972. 
STANZEL, Franz Karl. Narrative Situations in the Novel: Tom Jones, Moby-

Dick, The Ambassadors, Ulysses. Translated by James P. Pusack. Bloomington: Indiana University Press, 1971.

. A Theory of Narrative. Translated by Charlotte Goedsche. Cambridge: Cambridge University Press, 1986.

. Typische Formen des Romans. 6. Auflage. Göttingen: Vandenhoeck \& Ruprecht, 1964.

. Second thoughts on Narrative Situations in the Novel: Towards a "Grammar of fiction". Novel. A Forum on Fiction, (1978) 11: 247-264.

- Teller-characters and reflector-characters in narrative theory. Poetics Today (1981) 2: 5-15.

TADIÉ, Jean-Yves. O romance no século XX. Tradução Miguel Serras Pereira. Lisboa: Dom Quixote, 1992.

TINDALL, William York. A Portrait of the Artist as a Young Man. In: . $A$ Reader's Guide to James Joyce. New York: Syracuse University Press, 1995, p. 50-100.

TURNER, Victor W. O Processo Ritual: Estrutura e Anti-estrutura. Tradução Nancy Cambi de Castro. Petrópolis: Vozes, 1974.

UNTERSTEINER, Mario. Le origini della tragédia e del tragico: Dalla preistoria a Eschilo. Milano: Giulio Einaudi, 1955.

USPENSKY, Bóris. A Poetics of Composition: The Structure of the Artistic Text and Typology of a Compositional Form. Tradução V. Zavarin and S. Wittig. Berkeley: University of California Press, 1973.

VAN GENNEP, Arnold. Os Ritos de Passagem. Tradução Mariano Ferreira. Petrópolis: Vozes, 1978.

VATTIMO, Gianni. As Aventuras da Diferença: O que significa pensar depois de Heidegger e Nietzsche. Tradução José Eduardo Rodil. Lisboa: Edições 70, 1988.

VERENE, Donald Phillip. Vico's Science of Imagination. Ithaca and London: Cornell University Press, 1981. 
VERNANT, Jean-Pierre \& VIDAL-NAQUET, Pierre. Mito e Tragédia na Grécia Antiga. Tradução Anna Lia A. de Almeida Prado et alii. São Paulo: Brasiliense, 1988.

. Mito e Tragédia na Grécia Antiga. Vol. II. Tradução Bertha Halpem Gurovitz. São Paulo: Brasiliense, 1991.

VICO, Giambattista. A Ciência Nova. Tradução, prefácio e notas Marco Lucchesi. Rio de Janeiro: Record, 1999.

VITOUX, Pierre. Le jeu de la focalisation. Poétique (1982) 13: 359-468.

. Le récit dans The Ambassadors. Poétique (1975) 24: 462-479.

WATT, lan. A Ascensão do Romance. Tradução Hildegard Feist. São Paulo: Companhia das Letras, 1990.

. Mitos do individualismo moderno: Fausto, Dom Quixote, Dom Juan, Robinson Crusoé. Tradução Mário Pontes. Rio de Janeiro: Jorge Zahar, 1997.

WAUGH, Patricia. Metafiction (The Theory and Practice of Self-Conscious Fiction). London-New York: Methuen, 1984.

WEINSHEIMER, Joel. Philosophical Hermeneutics and Literary Theory. New Haven: Yale University Press, 1991.

WELLEK, René. Henry James's Literary Theory and Criticism. American Literature, n. 3, vol. XXX, nov. 1958, p. 293-321.

. Henry James. In: __. História da Crítica Moderna. Vol. 4. Tradução Hildegard Feist. São Paulo: Herder / EDUSP, 1972, p. 202-225.

WHITE, John J. Mythology in the Modern Novel: Study of Prefigurative Techniques. Princeton (N.J.): Princeton University Press, 1971.

WILSON, Edmund. O Castelo de Axel: Estudo sobre a Literatura Imaginativa de 1870 a 1930. Tradução José Paulo Paes. 9.ed. São Paulo: Cultrix, 1993.

WÖLFFLIN, Heinrich. Conceitos Fundamentais da História da Arte: O Problema da Evolução dos Estilos na Arte mais Recente. 4.ed. Tradução João Azenha Jr. São Paulo: Martins Fontes, 2000.

YACOBI, Tamar. Narrative Structure and Fictional Mediation. Poetics Today (1987) 8: 335-372. 